\title{
Statistische bijlage : schoolverlaters tussen onderwijs en arbeidsmarkt 2004
}

Citation for published version (APA):

Researchcentrum voor Onderwijs en Arbeidsmarkt, ROA. (2005). Statistische bijlage : schoolverlaters tussen onderwijs en arbeidsmarkt 2004. Researchcentrum voor Onderwijs en Arbeidsmarkt, Faculteit der Economische Wetenschappen. ROA Reports No. 6B https://doi.org/10.26481/umarep.200506B

Document status and date:

Published: 01/01/2005

DOI:

10.26481/umarep.200506B

Document Version:

Publisher's PDF, also known as Version of record

\section{Please check the document version of this publication:}

- A submitted manuscript is the version of the article upon submission and before peer-review. There can be important differences between the submitted version and the official published version of record.

People interested in the research are advised to contact the author for the final version of the publication, or visit the DOI to the publisher's website.

- The final author version and the galley proof are versions of the publication after peer review.

- The final published version features the final layout of the paper including the volume, issue and page numbers.

Link to publication

\footnotetext{
General rights rights.

- You may freely distribute the URL identifying the publication in the public portal. please follow below link for the End User Agreement:

www.umlib.nl/taverne-license

Take down policy

If you believe that this document breaches copyright please contact us at:

repository@maastrichtuniversity.nl

providing details and we will investigate your claim.
}

Copyright and moral rights for the publications made accessible in the public portal are retained by the authors and/or other copyright owners and it is a condition of accessing publications that users recognise and abide by the legal requirements associated with these

- Users may download and print one copy of any publication from the public portal for the purpose of private study or research.

- You may not further distribute the material or use it for any profit-making activity or commercial gain

If the publication is distributed under the terms of Article $25 \mathrm{fa}$ of the Dutch Copyright Act, indicated by the "Taverne" license above, 


\section{Statistische Bijlage \\ Schoolverlaters tussen onderwijs en arbeidsmarkt 2004}

ROA-R-2005/6B

Researchcentrum voor Onderwijs en Arbeidsmarkt

Faculteit der Economische Wetenschappen en Bedrijfskunde Universiteit Maastricht

Maastricht, september 2005 
Niets uit deze uitgave mag worden verveelvoudigd en/of openbaar gemaakt door middel van druk, fotokopie, microfilm, of op welke wijze ook, zonder voorafgaande schriftelijke toestemming van de directeur van het Researchcentrum voor Onderwijs en Arbeidsmarkt. In geval van overname van het datamateriaal moet telkens duidelijk als bron worden vermeld: "Researchcentrum voor Onderwijs en Arbeidsmarkt" of "ROA". Van publicaties waarin gebruik wordt gemaakt van gegevens uit deze Statistische Bijlage ontvangen wij gaarne een exemplaar.

Hoewel de grootst mogelijke zorg is besteed aan de inhoud van dit rapport, kan het ROA in generlei opzicht verantwoordelijkheid op zich nemen voor eventuele onvolledigheden of onjuistheden.

ISBN 90-5321-414-3

Sec05.071 


\section{Inhoud}

Bladzijde

Voorwoord

\section{A. Tabellen per opleidingssector}

\section{Bestemming van schoolverlaters}

A1.1 De uitstroom van schoolverlaters verbijzonderd naar geslacht, etniciteit en gemiddelde leeftijd op moment van enquête

A1.2 Vooropleiding van schoolverlaters

A1.3 Bestemming van schoolverlaters

A1.4 Gevolgde opleiding opnieuw kiezen?

\section{Doorstroom naar vervolgonderwijs}

A2.1 Doorstroom van schoolverlaters naar vervolgonderwijs

A2.2 Belangrijkste opleidingen van schoolverlaters die een vervolgopleiding zijn gaan volgen

A2.3 Oordeel van schoolverlaters over de aansluiting van de afgesloten opleiding met de vervolgopleiding

A2.4 Doorstroom van schoolverlaters naar kenniscentrum beroepsonderwijs bedrijfsleven

3 Intrede op de arbeidsmarkt

A3.1 Werkloosheid en gemiddelde intredewerkloosheid van schoolverlaters die zich aanbieden op de arbeidsmarkt

A3.2 Aard van het dienstverband van werkende schoolverlaters $\quad 22$

A3.3 Percentage werkende schoolverlaters met een flexibele aanstelling 24

A3.4 Belangrijkste bedrijfsgroepen waarin schoolverlaters werkzaam zijn 26

A3.5 Belangrijkste beroepsgroepen waarin schoolverlaters werkzaam zijn 31

A3.6 Grootte van de organisatie waarin schoolverlaters werkzaam zijn 36

A3.7 Beloning van werkende schoolverlaters 38

A3.8 Vereist opleidingsniveau voor de huidige functie volgens de werkgever 40

A3.9 Vereiste opleidingsrichting voor de huidige functie volgens de werkgever 42

A3.10 Wekelijkse arbeidsduur van werkende schoolverlaters $\quad 44$

A3.11 Oordeel van de werkende schoolverlaters over de aansluiting tussen de
afgesloten opleiding en de huidige functie

A3.12 Percentage werkende schoolverlaters dat op zoek is naar een andere baan $\quad 47$

\section{Kernindicatoren}

A4.1 Enkele kernindicatoren 


\section{B. Tabellen per opleidingsrichting}

1 Bestemming van schoolverlaters

B1.1 De uitstroom van schoolverlaters verbijzonderd naar geslacht, etniciteit en gemiddelde leeftijd op moment van enquête

B1.2 Vooropleiding van schoolverlaters $\quad 57$

$\begin{array}{ll}\text { B1.3 Bestemming van schoolverlaters } & 61\end{array}$

B1.4 Gevolgde opleiding opnieuw kiezen?

\section{Doorstroom naar vervolgonderwijs}

$\begin{array}{lll}\text { B2.1 Doorstroom van schoolverlaters naar vervolgonderwijs } & 66\end{array}$

B2.2 Belangrijkste opleidingen van schoolverlaters die een vervolgopleiding zijn gaan volgen

B2.3 Oordeel van schoolverlaters over de aansluiting van de afgesloten opleiding met de vervolgopleiding

B2.4 Doorstroom van schoolverlaters naar kenniscentrum beroepsonderwijs bedrijfsleven

3 Intrede op de arbeidsmarkt

B3.1 Werkloosheid en gemiddelde intredewerkloosheid van schoolverlaters die zich aanbieden op de arbeidsmarkt

B3.2 Aard van het dienstverband van werkende schoolverlaters 90

B3.3 Percentage werkende schoolverlaters met een flexibele aanstelling 94

B3.4 Belangrijkste bedrijfsgroepen waarin schoolverlaters werkzaam zijn 96

B3.5 Belangrijkste beroepsgroepen waarin schoolverlaters werkzaam zijn 107

B3.6 Grootte van de organisatie waarin schoolverlaters werkzaam zijn 118

B3.7 Beloning van werkende schoolverlaters $\quad 120$

B3.8 Vereist opleidingsniveau voor de huidige functie volgens de werkgever 122

B3.9 Vereiste opleidingsrichting voor de huidige functie volgens de werkgever $\quad 124$

B3.10 Wekelijkse arbeidsduur van werkende schoolverlaters $\quad 126$

B3.11 Oordeel van de werkende schoolverlaters over de aansluiting tussen de

$\begin{array}{ll}\text { afgesloten opleiding en de huidige functie } & 128 \\ \text { B3.12 Percentage werkende schoolverlaters dat op zoek is naar een andere baan } & 130\end{array}$

4 Kernindicatoren

B4.1 Enkele kernindicatoren 


\section{Respons}

C.1 Ongewogen aantal respondenten verbijzonderd naar bestemming per opleidingssector

C.2 Naar landelijke populatie gewogen aantal schoolverlaters verbijzonderd naar bestemming per opleidingssector

C.3 Responspercentage per opleidingssector

C.4 Ongewogen aantal respondenten verbijzonderd naar bestemming per opleidingsrichting

C.5 Naar landelijke populatie gewogen aantal schoolverlaters verbijzonderd naar bestemming per opleidingsrichting

C.6 Responspercentage per opleidingsrichting

\section{Opleidingsindeling}

Overzicht van opleidingen per opleidingssector 

Tabellenoverzicht Statistische Bijlage

Schoolverlaters tussen Onderwijs en Arbeidsmarkt

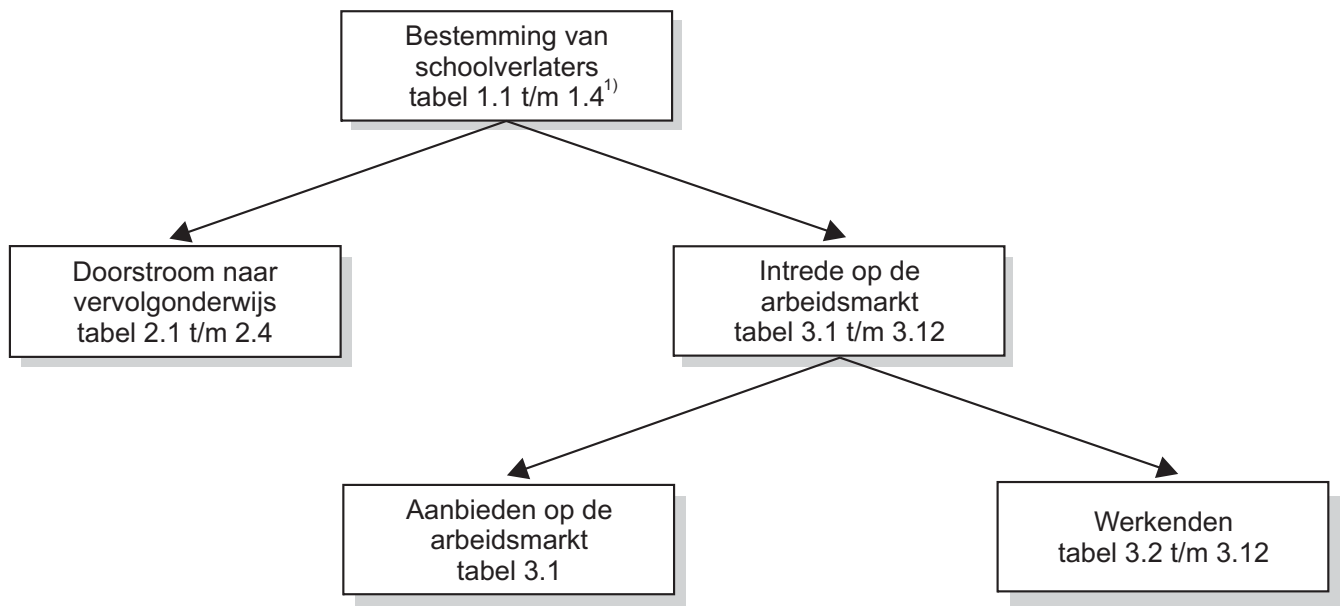

1) Tabelnummers gelden voor het A-deel en het B-deel van de statistische bijlage. Het A-deel bestaat uit tabellen naar opleidingssector, het B-deel uit tabellen naar opleidingsrichting. 



\section{Voorwoord}

In deze Statistische Bijlage bij het rapport Schoolverlaters tussen onderwijs en arbeidsmarkt 2004 wordt een overzicht gegeven van de belangrijkste resultaten van de schoolverlatersonderzoeken die door het Researchcentrum voor Onderwijs en Arbeidsmarkt (ROA) in het najaar van 2004 zijn gehouden onder schoolverlaters en afgestudeerden van het school- of studiejaar 2002/2003. De gegevens bestrijken de volle breedte van het Nederlandse onderwijssysteem en hebben betrekking op de situatie van schoolverlaters en afgestudeerden ongeveer anderhalf jaar na het voltooien van de opleiding. Allereerst betreft het de VO-Monitor. Deze enquête is gericht op schoolverlaters van het algemeen voortgezet onderwijs (HAVO, VWO) en het voorbereidend beroepsonderwijs (VMBO). Vervolgens de BVE-Monitor, een enquête onder schoolverlaters van de beroepsopleidende (BOL) en beroepsbegeleidende leerweg $(\mathrm{BBL})$ van het secundair beroepsonderwijs. Tot slot zijn gegevens opgenomen afkomstig uit de HBO-Monitor en WO-Monitor. Dit zijn volledig vergelijkbare enquêtes gericht op afgestudeerden van het hoger onderwijs, die worden uitgevoerd onder toezicht van respectievelijk de HBO-raad en de Vereniging van Samenwerkende Nederlandse Universiteiten (VSNU).

Voor alle getoonde gegevens geldt dat het gaat om gediplomeerde schoolverlaters en afgestudeerden. Bovendien betreft het alleen de uitstroom van voltijdopleidingen. Een uitzondering hierop wordt gevormd door de gediplomeerde schoolverlaters van de BBL die leren en werken combineren.

In deel A worden de belangrijkste gegevens per onderwijssoort en opleidingssector (bijvoorbeeld BOL niveau 1/2 techniek, HBO economie, WO gezondheidszorg) gepresenteerd. Binnen het secundair beroepsonderwijs zijn daarbij de niveaus 1 en 2 (assistent beroepsbeoefenaar (AB) en beginnend beroepsbeoefenaar (BB)) aan de ene kant en de niveaus 3 en 4 (zelfstandig beroepsbeoefenaar (ZB) en (midden)kaderfunctionaris ((M)KF) of specialist) aan de andere kant samengenomen. Deel B geeft vervolgens voor de opleidingsrichtingen van $\mathrm{VMBO}, \mathrm{BOL}$ en $\mathrm{BBL}$ een gedetailleerder overzicht. ${ }^{1}$ Daarbij worden alleen voor die opleidingsrichtingen cijfers gepresenteerd waarvoor de resultaten voldoende betrouwbaar worden geacht. Daartoe is een ondergrens van 15 respondenten gehanteerd. Bij tabellen die betrekking hebben op de beroepsbevolking of op werkenden is de ondergrens gesteld op 15 respondenten die tot de beroepsbevolking behoren. Bij tabellen die betrekking hebben op vervolgopleidingen of cursussen is de ondergrens gelegd bij minimaal 15 respondenten die een vervolgopleiding respectievelijk cursus hebben gevolgd. Overigens kunnen de gepresenteerde percentages bij sommige tabellen vanwege ontbrekende waarnemingen - op een geringer aantal respondenten zijn gebaseerd. Hiermee dient bij de interpretatie van de gegevens rekening te worden gehouden.

Binnen de delen A en B is een onderverdeling gemaakt. Het eerste onderdeel van beide delen heeft betrekking op de bestemming van schoolverlaters: werken, leren of een combinatie van werken en leren via de BBL. Het tweede onderdeel gaat dieper in op degenen die verder leren, terwijl het derde onderdeel de intrede op de arbeidsmarkt nader beschrijft. De groep die werken en leren combineert via de BBL komt zowel in het tweede onderdeel ('doorstroom naar vervolgonderwijs') als in het derde onderdeel ('intrede op de arbeidsmarkt') aan de orde. Ten slotte bevatten de delen $A$ en $B$ een samenvattende tabel met daarin de belangrijkste kernindicatoren.

1. Voor een gedetailleerd beeld van de resultaten voor het HBO wordt verwezen naar het onlangs verschenen Statistisch supplement van de HBO-Monitor 2004 (www.kengetallen.hbo.nl). Uitvoeriger resultaten van de WO-Monitor 2004 zijn via de VSNU (www.vsnu.nl) en de WO-Monitor website (www.womonitor.nl) beschikbaar. 
Deel C geeft enkele achtergrondcijfers van de enquêtes: ongewogen en opgehoogde aantallen schoolverlaters, alsmede de responspercentages. In deel $D$ is tot slot een overzicht opgenomen van de in de enquêtes opgenomen opleidingen per sector. 
A. Tabellen per opleidingssector 



\section{Inhoud}

1 Bestemming van schoolverlaters

A1.1 De uitstroom van schoolverlaters verbijzonderd naar geslacht, etniciteit en gemiddelde leeftijd op moment van enquête

A1.2 Vooropleiding van schoolverlaters

A1.3 Bestemming van schoolverlaters

A1.4 Gevolgde opleiding opnieuw kiezen?

\section{Doorstroom naar vervolgonderwijs}

A2.1 Doorstroom van schoolverlaters naar vervolgonderwijs

A2.2 Belangrijkste opleidingen van schoolverlaters die een vervolgopleiding zijn gaan volgen

A2.3 Oordeel van schoolverlaters over de aansluiting van de afgesloten opleiding met de vervolgopleiding

A2.4 Doorstroom van schoolverlaters naar kenniscentrum beroepsonderwijs bedrijfsleven

3 Intrede op de arbeidsmarkt

A3.1 Werkloosheid en gemiddelde intredewerkloosheid van schoolverlaters die zich aanbieden op de arbeidsmarkt

A3.2 Aard van het dienstverband van werkende schoolverlaters

A3.3 Percentage werkende schoolverlaters met een flexibele aanstelling

A3.4 Belangrijkste bedrijfsgroepen waarin schoolverlaters werkzaam zijn

A3.5 Belangrijkste beroepsgroepen waarin schoolverlaters werkzaam zijn

A3.6 Grootte van de organisatie waarin schoolverlaters werkzaam zijn

A3.7 Beloning van werkende schoolverlaters

A3.8 Vereist opleidingsniveau voor de huidige functie volgens de werkgever

A3.9 Vereiste opleidingsrichting voor de huidige functie volgens de werkgever

A3.10 Wekelijkse arbeidsduur van werkende schoolverlaters

A3.11 Oordeel van de werkende schoolverlaters over de aansluiting tussen de afgesloten opleiding en de huidige functie

A3.12 Percentage werkende schoolverlaters dat op zoek is naar een andere baan

4 Kernindicatoren

A4.1 Enkele kernindicatoren 
Tabel A1.1

De uitstroom van schoolverlaters verbijzonderd naar geslacht, etniciteit en gemiddelde leeftijd op moment van enquête

\begin{tabular}{|c|c|c|c|}
\hline Opleidingssector & $\begin{array}{r}\text { vrouw } \\
\%\end{array}$ & $\begin{array}{r}\text { allochtoon } \\
\%\end{array}$ & $\begin{array}{l}\text { leeftijd } \\
\text { gem. }\end{array}$ \\
\hline HAVO/VWO & 55 & 7 & 18,9 \\
\hline HAVO & 55 & 8 & 18,6 \\
\hline VWO & 54 & 7 & 19,2 \\
\hline VMBO & 47 & 10 & 17,5 \\
\hline Theoretische leerweg & 50 & 11 & 17,4 \\
\hline Landbouw & 52 & 4 & 17,6 \\
\hline Techniek & 3 & 4 & 17,6 \\
\hline Economie & 52 & 20 & 17,5 \\
\hline Gezondheidszorg & 97 & 10 & 17,4 \\
\hline BOL niveau $1 / 2$ & 51 & 25 & 20,9 \\
\hline Landbouw & 46 & 4 & 19,8 \\
\hline Techniek & 5 & 25 & 21,3 \\
\hline Economie & 52 & 31 & 20,6 \\
\hline Gezondheidszorg & 92 & 13 & 21,5 \\
\hline BOL niveau $3 / 4$ & 58 & 10 & 21,7 \\
\hline Landbouw & 43 & 2 & 21,3 \\
\hline Techniek & 14 & 8 & 22,2 \\
\hline Economie & 52 & 14 & 21,5 \\
\hline Gezondheidszorg & 88 & 8 & 21,5 \\
\hline Gedrag en maatschappij & 92 & 10 & 21,6 \\
\hline BBL niveau $1 / 2$ & 37 & 10 & 26,7 \\
\hline Landbouw & 33 & 6 & 30,7 \\
\hline Techniek & 1 & 8 & 22,2 \\
\hline Economie & 52 & 10 & 23,8 \\
\hline Gezondheidszorg & 96 & 15 & 38,3 \\
\hline BBL niveau $3 / 4$ & 63 & 7 & 30,2 \\
\hline Landbouw & 30 & 4 & 27,4 \\
\hline Techniek & 1 & 8 & 25,1 \\
\hline Economie & 37 & 9 & 23,2 \\
\hline Gezondheidszorg & 92 & 6 & 34,3 \\
\hline Gedrag en maatschappij & 92 & 11 & 33,6 \\
\hline HBO & 56 & 8 & 24,6 \\
\hline Landbouw & 35 & 2 & 24,5 \\
\hline Onderwijs & 82 & 5 & 24,7 \\
\hline Techniek & 16 & 7 & 24,6 \\
\hline Economie & 51 & 11 & 24,4 \\
\hline Gezondheidszorg & 83 & 5 & 24,6 \\
\hline Gedrag en maatschappij & 86 & 8 & 24,2 \\
\hline Taal en cultuur & 59 & 10 & 27,2 \\
\hline wo & 54 & 8 & 27,0 \\
\hline Landbouw & 51 & 5 & 25,9 \\
\hline Techniek & 22 & 7 & 26,5 \\
\hline Economie & 34 & 9 & 26,6 \\
\hline Gezondheidszorg & 66 & 10 & 27,3 \\
\hline Gedrag en maatschappij & 76 & 7 & 27,4 \\
\hline Taal en cultuur & 71 & 8 & 27,9 \\
\hline Recht en openbare orde & 60 & 10 & 27,6 \\
\hline Natuurwetenschappen & 44 & 10 & 26,0 \\
\hline
\end{tabular}


Tabel A1.1 (vervolg)

De uitstroom van schoolverlaters verbijzonderd naar geslacht, etniciteit en gemiddelde leeftijd op moment van enquête

\begin{tabular}{lccr} 
Opleidingssector & $\begin{array}{r}\text { vrouw } \\
\%\end{array}$ & $\begin{array}{r}\text { allochtoon } \\
\%\end{array}$ & $\begin{array}{r}\text { leeftijd } \\
\text { gem. }\end{array}$ \\
\hline Totaal & 53 & 10 & 21,7 \\
\hline
\end{tabular}

\section{Toelichting}

- Om als allochtoon te worden aangemerkt, dient de schoolverlater of ten minste één van zijn of haar ouders te zijn geboren in één van de landen die worden genoemd in de Wet SAMEN (Stimulering Arbeidsdeelname Minderheden). De Wet SAMEN is overigens per 31 december 2003 niet meer van toepassing.

- Het betreft de leeftijd per onderzoeksdatum ongeveer anderhalf jaar na schoolverlaten.

- Voor het WO zijn de resultaten met betrekking tot allochtonen gebaseerd op 12 universiteiten. 
Tabel A1.2

Vooropleiding van schoolverlaters

\begin{tabular}{|c|c|c|c|c|c|c|c|c|}
\hline Opleidingssector & $\begin{array}{r}\text { MAVO } \\
\%\end{array}$ & $\begin{array}{r}\text { HAVO } \\
\%\end{array}$ & $\begin{array}{r}\text { VWO } \\
\%\end{array}$ & $\begin{array}{r}\text { VBO } \\
\%\end{array}$ & $\begin{array}{r}\mathrm{BOL} \\
\%\end{array}$ & $\begin{array}{r}\text { BBL } \\
\%\end{array}$ & $\begin{array}{r}\mathrm{HBO} \\
\%\end{array}$ & $\begin{array}{r}\text { overig } \\
\%\end{array}$ \\
\hline BOL niveau $1 / 2$ & 25 & 2 & 1 & 56 & 7 & 2 & 0 & 8 \\
\hline Landbouw & 6 & 0 & 2 & 55 & 10 & $\overline{0}$ & 0 & 26 \\
\hline Techniek & 21 & 1 & 1 & 60 & 7 & 4 & 0 & 5 \\
\hline Economie & 28 & 2 & 1 & 52 & 9 & 2 & 0 & 7 \\
\hline Gezondheidszorg & 22 & 1 & 1 & 64 & 2 & 0 & 0 & 9 \\
\hline BOL niveau $3 / 4$ & 65 & 8 & 0 & 22 & 2 & 0 & 0 & 2 \\
\hline Landbouw & 51 & 6 & 1 & 39 & 1 & 0 & 0 & 3 \\
\hline Techniek & 62 & 12 & 1 & 22 & 2 & 0 & 0 & 2 \\
\hline Economie & 73 & 11 & 0 & 13 & 2 & 0 & 0 & 1 \\
\hline Gezondheidszorg & 64 & 6 & 1 & 25 & 2 & 0 & 0 & 2 \\
\hline Gedrag en maatschappij & 63 & 2 & 0 & 29 & 3 & 0 & 0 & 3 \\
\hline BBL niveau $1 / 2$ & 24 & 2 & 2 & 47 & 2 & 12 & 0 & 10 \\
\hline Landbouw & 18 & 3 & 2 & 42 & 5 & 14 & 0 & 16 \\
\hline Techniek & 22 & 0 & 1 & 54 & 3 & 12 & 0 & 7 \\
\hline Economie & 32 & 2 & 1 & 45 & 2 & 8 & 0 & 9 \\
\hline Gezondheidszorg & 19 & 6 & 4 & 36 & 0 & 17 & 0 & 18 \\
\hline BBL niveau $3 / 4$ & 38 & 7 & 2 & 31 & 5 & 11 & 0 & 6 \\
\hline Landbouw & 31 & 8 & 2 & 38 & 3 & 12 & 0 & 6 \\
\hline Techniek & 25 & 4 & 2 & 52 & 3 & 11 & 0 & 4 \\
\hline Economie & 47 & 9 & 1 & 30 & 1 & 11 & 0 & 1 \\
\hline Gezondheidszorg & 36 & 7 & 2 & 27 & 8 & 12 & 0 & 7 \\
\hline Gedrag en maatschappij & 47 & 10 & 4 & 23 & 3 & 5 & 0 & 9 \\
\hline HBO & 0 & 47 & 23 & 0 & 26 & 0 & 3 & 0 \\
\hline Landbouw & 0 & 45 & 17 & 0 & 37 & 0 & 1 & 0 \\
\hline Onderwijs & 1 & 59 & 15 & 0 & 20 & 0 & 5 & 0 \\
\hline Techniek & 0 & 36 & 23 & 0 & 37 & 0 & 3 & 0 \\
\hline Economie & 0 & 47 & 28 & 0 & 22 & 0 & 1 & 0 \\
\hline Gezondheidszorg & 0 & 54 & 26 & 0 & 14 & 0 & 4 & 1 \\
\hline
\end{tabular}


Tabel A1.2 (vervolg)

Vooropleiding van schoolverlaters

\begin{tabular}{|c|c|c|c|c|c|c|c|c|}
\hline Opleidingssector & $\begin{array}{r}\text { MAVO } \\
\%\end{array}$ & $\begin{array}{r}\text { HAVO } \\
\%\end{array}$ & $\begin{array}{r}\text { VWO } \\
\%\end{array}$ & $\begin{array}{r}\text { VBO } \\
\%\end{array}$ & $\begin{array}{r}\text { BOL } \\
\%\end{array}$ & $\begin{array}{r}\text { BBL } \\
\%\end{array}$ & $\begin{array}{r}\mathrm{HBO} \\
\%\end{array}$ & $\begin{array}{r}\text { overig } \\
\%\end{array}$ \\
\hline \multicolumn{9}{|l|}{ HBO (vervolg) } \\
\hline Gedrag en maatschappij & 1 & 51 & 13 & 0 & 33 & 0 & 2 & 0 \\
\hline Taal en cultuur & 2 & 36 & 31 & 0 & 18 & 0 & 12 & 2 \\
\hline wo & 0 & 2 & 75 & 0 & 0 & 0 & 19 & 5 \\
\hline Landbouw & 0 & 1 & 84 & 0 & 0 & 0 & 13 & 2 \\
\hline Techniek & 0 & 0 & 84 & 0 & 0 & 0 & 14 & 1 \\
\hline Economie & 0 & 1 & 70 & 0 & 0 & 0 & 26 & 3 \\
\hline Gezondheidszorg & 0 & 1 & 79 & 0 & 0 & 0 & 9 & 11 \\
\hline Gedrag en maatschappij & 0 & 3 & 65 & 0 & 0 & 0 & 28 & 4 \\
\hline Taal en cultuur & 0 & 5 & 73 & 0 & 0 & 0 & 16 & 7 \\
\hline Recht en openbare orde & 0 & 2 & 78 & 0 & 0 & 0 & 15 & 6 \\
\hline Natuurwetenschappen & 0 & 1 & 85 & 0 & 0 & 0 & 12 & 2 \\
\hline Totaal & 27 & 17 & 17 & 20 & 9 & 3 & 3 & 4 \\
\hline
\end{tabular}


Tabel A1.3

Bestemming van schoolverlaters

\begin{tabular}{|c|c|c|c|c|c|}
\hline Opleidingssector & $\begin{array}{r}\text { studie } \\
\%\end{array}$ & $\begin{array}{r}\text { BBL } \\
\%\end{array}$ & $\begin{array}{r}\text { betaald werk } \\
\%\end{array}$ & $\begin{array}{r}\text { werkloos } \\
\%\end{array}$ & $\begin{array}{r}\text { anders } \\
\%\end{array}$ \\
\hline HAVO/VWO & 92 & 2 & 4 & 1 & 2 \\
\hline HAVO & 88 & 3 & 6 & 1 & 2 \\
\hline VWO & 96 & 1 & 2 & 0 & 1 \\
\hline VMBO & 70 & 14 & 12 & 1 & 2 \\
\hline Theoretische leerweg & 87 & 5 & 5 & 1 & 2 \\
\hline Landbouw & 62 & 19 & 13 & 3 & 3 \\
\hline Techniek & 32 & 36 & 29 & 0 & 3 \\
\hline Economie & 63 & 15 & 17 & 3 & 2 \\
\hline Gezondheidszorg & 73 & 14 & 8 & 2 & 2 \\
\hline BOL niveau $1 / 2$ & 35 & 15 & 32 & 10 & 8 \\
\hline Landbouw & 26 & 8 & 44 & 11 & 11 \\
\hline Techniek & 33 & 20 & 30 & 10 & 7 \\
\hline Economie & 33 & 14 & 34 & 13 & 6 \\
\hline Gezondheidszorg & 42 & 14 & 26 & 6 & 12 \\
\hline BOL niveau 3/4 & 46 & 4 & 43 & 3 & 3 \\
\hline Landbouw & 38 & 5 & 49 & 4 & 4 \\
\hline Techniek & 53 & 3 & 39 & 3 & 2 \\
\hline Economie & 51 & 4 & 37 & 4 & 3 \\
\hline Gezondheidszorg & 28 & 6 & 60 & 2 & 3 \\
\hline Gedrag en maatschappij & 46 & 4 & 42 & 3 & 5 \\
\hline BBL niveau $1 / 2$ & 4 & 20 & 67 & 5 & 4 \\
\hline Landbouw & 2 & 17 & 73 & 2 & 6 \\
\hline Techniek & 3 & 22 & 66 & 5 & 4 \\
\hline Economie & 10 & 21 & 59 & 6 & 4 \\
\hline Gezondheidszorg & 0 & 15 & 77 & 6 & 2 \\
\hline BBL niveau 3/4 & 7 & 5 & 80 & 3 & 5 \\
\hline Landbouw & 3 & 7 & 78 & 2 & 11 \\
\hline Techniek & 7 & 10 & 76 & 1 & 5 \\
\hline Economie & 19 & 4 & 67 & 7 & 3 \\
\hline Gezondheidszorg & 1 & 4 & 87 & 2 & 5 \\
\hline Gedrag en maatschappij & 10 & 3 & 80 & 2 & 5 \\
\hline HBO & 17 & $\mathbf{x}$ & 76 & 4 & 3 \\
\hline Landbouw & 20 & $X$ & 72 & 5 & 3 \\
\hline Onderwijs & 7 & $X$ & 87 & 3 & 3 \\
\hline Techniek & 23 & $x$ & 71 & 3 & 2 \\
\hline Economie & 24 & $x$ & 70 & 4 & 2 \\
\hline Gezondheidszorg & 9 & $x$ & 86 & 3 & 3 \\
\hline Gedrag en maatschappij & 12 & $X$ & 81 & 4 & 3 \\
\hline Taal en cultuur & 11 & $X$ & 78 & 5 & 6 \\
\hline WO & 5 & $\mathbf{x}$ & 88 & 4 & 3 \\
\hline Landbouw & 4 & $X$ & 91 & 4 & 1 \\
\hline Techniek & 2 & $X$ & 93 & 3 & 2 \\
\hline Economie & 2 & $x$ & 92 & 3 & 2 \\
\hline Gezondheidszorg & 9 & $X$ & 86 & 1 & 4 \\
\hline Gedrag en maatschappij & 5 & $x$ & 86 & 5 & 4 \\
\hline Taal en cultuur & 9 & $X$ & 80 & 6 & 5 \\
\hline Recht en openbare orde & 4 & $X$ & 92 & 3 & 1 \\
\hline Natuurwetenschappen & 10 & $X$ & 84 & 4 & 3 \\
\hline Totaal & 48 & 7 & 39 & 3 & 3 \\
\hline
\end{tabular}

$\mathrm{x}=$ antwoordcategorie niet opgenomen 
Tabel A1.4

Gevolgde opleiding opnieuw kiezen?

\begin{tabular}{|c|c|c|c|}
\hline Opleidingssector & $\begin{array}{r}\text { zelfde } \\
\text { opleiding } \\
\%\end{array}$ & $\begin{array}{r}\text { andere } \\
\text { opleiding } \\
\%\end{array}$ & $\begin{array}{r}\text { geen } \\
\text { opleiding } \\
\%\end{array}$ \\
\hline BOL niveau $1 / 2$ & 61 & 33 & 6 \\
\hline Landbouw & 59 & 28 & 13 \\
\hline Techniek & 62 & 34 & 4 \\
\hline Economie & 58 & 35 & 7 \\
\hline Gezondheidszorg & 68 & 27 & 5 \\
\hline BOL niveau $3 / 4$ & 76 & 22 & 1 \\
\hline Landbouw & 74 & 23 & 3 \\
\hline Techniek & 80 & 19 & 1 \\
\hline Economie & 70 & 29 & 1 \\
\hline Gezondheidszorg & 80 & 19 & 1 \\
\hline Gedrag en maatschappij & 81 & 18 & 0 \\
\hline BBL niveau $1 / 2$ & 70 & 19 & 11 \\
\hline Landbouw & 67 & 18 & 15 \\
\hline Techniek & 72 & 20 & 8 \\
\hline Economie & 57 & 26 & 18 \\
\hline Gezondheidszorg & 86 & 8 & 6 \\
\hline BBL niveau $3 / 4$ & 80 & 17 & 3 \\
\hline Landbouw & 79 & 17 & 5 \\
\hline Techniek & 83 & 12 & 5 \\
\hline Economie & 64 & 34 & 3 \\
\hline Gezondheidszorg & 84 & 12 & 4 \\
\hline Gedrag en maatschappij & 82 & 16 & 2 \\
\hline HBO & 78 & 22 & 0 \\
\hline Landbouw & 75 & 24 & 0 \\
\hline Onderwijs & 88 & 12 & 0 \\
\hline Techniek & 79 & 21 & 1 \\
\hline Economie & 70 & 29 & 1 \\
\hline Gezondheidszorg & 84 & 16 & 0 \\
\hline Gedrag en maatschappij & 76 & 24 & 0 \\
\hline Taal en cultuur & 85 & 15 & 1 \\
\hline wo & 81 & 18 & 1 \\
\hline Landbouw & 77 & 22 & 1 \\
\hline Techniek & 82 & 17 & 1 \\
\hline Economie & 83 & 17 & 1 \\
\hline Gezondheidszorg & 89 & 11 & 0 \\
\hline Gedrag en maatschappij & 76 & 23 & 1 \\
\hline Taal en cultuur & 73 & 27 & 0 \\
\hline Recht en openbare orde & 88 & 11 & 0 \\
\hline Natuurwetenschappen & 79 & 20 & 1 \\
\hline Totaal & 76 & 22 & 3 \\
\hline
\end{tabular}


Tabel A2.1

Doorstroom van schoolverlaters naar vervolgonderwijs

\begin{tabular}{|c|c|c|c|c|c|c|c|c|c|c|c|c|}
\hline & $\begin{array}{r}\text { verder } \\
\text { leren } \\
\%\end{array}$ & $\begin{array}{r}\text { HAVO } \\
\%\end{array}$ & $\begin{array}{r}\text { VWO } \\
\%\end{array}$ & $\begin{array}{r}\text { VMBO } \\
\%\end{array}$ & $\begin{array}{r}\text { BOL } \\
\text { niv. } 1 / 2 \\
\%\end{array}$ & $\begin{array}{r}\text { BOL } \\
\text { niv. } 3 / 4 \\
\%\end{array}$ & $\begin{array}{r}\text { BBL } \\
\text { niv. } 1 / 2 \\
\%\end{array}$ & $\begin{array}{r}\text { BBL } \\
\text { niv. } 3 / 4 \\
\%\end{array}$ & $\begin{array}{r}\mathrm{HBO} \\
\%\end{array}$ & $\begin{array}{r}\text { post } \\
\text { HBO } \\
\%\end{array}$ & $\begin{array}{r}\text { WO } \\
\%\end{array}$ & $\begin{array}{r}\text { post } \\
\text { WO } \\
\%\end{array}$ \\
\hline HAVO/VWO & 91 & 0 & 1 & 0 & 0 & 3 & 0 & 0 & 62 & 0 & 34 & 0 \\
\hline HAVO & 90 & 0 & 1 & 0 & 0 & 4 & 0 & 1 & 92 & 0 & 1 & 0 \\
\hline VWO & 91 & 0 & 0 & 0 & 0 & 0 & 0 & 0 & 23 & 0 & 77 & 0 \\
\hline VMBO & 88 & 3 & 0 & 0 & 18 & 60 & 13 & 7 & 0 & 0 & 0 & 0 \\
\hline Theoretische leerweg & 90 & 6 & 0 & 0 & 7 & 80 & 3 & 5 & 0 & 0 & 0 & 0 \\
\hline Landbouw & 84 & 0 & 0 & 0 & 40 & 36 & 15 & 9 & 0 & 0 & 0 & 0 \\
\hline Techniek & 84 & 0 & 0 & 0 & 22 & 25 & 45 & 8 & 0 & 0 & 0 & 0 \\
\hline Economie & 84 & 0 & 0 & 0 & 33 & 45 & 15 & 6 & 0 & 0 & 0 & 0 \\
\hline Gezondheidszorg & 92 & 0 & 0 & 0 & 28 & 51 & 9 & 11 & 0 & 0 & 0 & 0 \\
\hline BOL niveau $1 / 2$ & 46 & 0 & 0 & 0 & 14 & 43 & 12 & 25 & 6 & 0 & 0 & 0 \\
\hline Landbouw & 39 & 0 & 0 & 0 & 0 & 65 & 9 & 26 & 0 & 0 & 0 & 0 \\
\hline Techniek & 55 & 0 & 0 & 0 & 11 & 30 & 24 & 27 & 8 & 0 & 0 & 0 \\
\hline Economie & 41 & 0 & 0 & 0 & 22 & 42 & 10 & 23 & 3 & 0 & 0 & 0 \\
\hline Gezondheidszorg & 49 & 0 & 0 & 0 & 4 & 56 & 3 & 27 & 10 & 0 & 0 & 0 \\
\hline BOL niveau $3 / 4$ & 51 & 0 & 0 & 0 & 0 & 7 & 1 & 5 & 87 & 0 & 0 & 0 \\
\hline Landbouw & 47 & 0 & 0 & 0 & 1 & 24 & 0 & 8 & 67 & 0 & 0 & 0 \\
\hline Techniek & 56 & 0 & 0 & 0 & 0 & 2 & 1 & 2 & 94 & 0 & 0 & 0 \\
\hline Economie & 55 & 0 & 0 & 0 & 0 & 4 & 0 & 3 & 92 & 0 & 0 & 0 \\
\hline Gezondheidszorg & 36 & 0 & 0 & 0 & 0 & 19 & 0 & 14 & 67 & 0 & 0 & 0 \\
\hline Gedrag en maatschappij & 51 & 0 & 0 & 0 & 1 & 7 & 1 & 4 & 87 & 0 & 0 & 0 \\
\hline BBL niveau $1 / 2$ & 25 & 0 & 0 & 0 & 7 & 4 & 10 & 74 & 5 & 0 & 0 & 0 \\
\hline Landbouw & 29 & 0 & 0 & 0 & 0 & 3 & 15 & 82 & 0 & 0 & 0 & 0 \\
\hline Techniek & 29 & 0 & 0 & 0 & 3 & 4 & 7 & 86 & 0 & 0 & 0 & 0 \\
\hline Economie & 25 & 0 & 0 & 0 & 13 & 6 & 11 & 56 & 14 & 0 & 0 & 0 \\
\hline Gezondheidszorg & 17 & 0 & 0 & 0 & 4 & 0 & 11 & 85 & 0 & 0 & 0 & 0 \\
\hline
\end{tabular}


Tabel A2.1 (vervolg)

Doorstroom van schoolverlaters naar vervolgonderwijs

\begin{tabular}{|c|c|c|c|c|c|c|c|c|c|c|c|c|}
\hline & $\begin{array}{r}\text { verder } \\
\text { leren } \\
\%\end{array}$ & $\begin{array}{r}\text { HAVO } \\
\%\end{array}$ & $\begin{array}{r}\text { VWO } \\
\%\end{array}$ & $\begin{array}{r}\text { VMBO } \\
\%\end{array}$ & $\begin{array}{r}\text { BOL } \\
\text { niv. } 1 / 2 \\
\%\end{array}$ & $\begin{array}{r}\text { BOL } \\
\text { niv. } 3 / 4 \\
\%\end{array}$ & $\begin{array}{r}\text { BBL } \\
\text { niv. } 1 / 2 \\
\%\end{array}$ & $\begin{array}{r}\text { BBL } \\
\text { niv. } 3 / 4 \\
\%\end{array}$ & $\begin{array}{r}\mathrm{HBO} \\
\%\end{array}$ & $\begin{array}{r}\text { post } \\
\text { HBO } \\
\%\end{array}$ & $\begin{array}{r}\text { WO } \\
\%\end{array}$ & $\begin{array}{r}\text { post } \\
\text { WO } \\
\%\end{array}$ \\
\hline BBL niveau $3 / 4$ & 16 & 0 & 0 & 0 & 3 & 9 & 2 & 29 & 57 & 0 & 0 & 0 \\
\hline Landbouw & 21 & 0 & 0 & 0 & 0 & 10 & 5 & 42 & 43 & 0 & 0 & 0 \\
\hline Techniek & 17 & 0 & 0 & 0 & 17 & 14 & 8 & 14 & 46 & 0 & 0 & 0 \\
\hline Economie & 31 & 0 & 0 & 0 & 0 & 4 & 0 & 38 & 58 & 0 & 0 & 0 \\
\hline Gezondheidszorg & 8 & 0 & 0 & 0 & 0 & 22 & 0 & 26 & 52 & 0 & 0 & 0 \\
\hline Gedrag en maatschappij & 17 & 0 & 0 & 0 & 0 & 0 & 0 & 25 & 75 & 0 & 0 & 0 \\
\hline HBO & 32 & 0 & 0 & 0 & 0 & 1 & 0 & 0 & 26 & 0 & 71 & 2 \\
\hline Landbouw & 30 & 0 & 1 & 0 & 0 & 0 & 0 & 0 & 22 & 0 & 76 & 1 \\
\hline Onderwijs & 27 & 0 & 0 & 0 & 0 & 1 & 0 & 0 & 61 & 0 & 37 & 1 \\
\hline Techniek & 35 & 0 & 0 & 0 & 0 & 1 & 0 & 0 & 17 & 0 & 82 & 1 \\
\hline Economie & 39 & 0 & 0 & 0 & 0 & 0 & 0 & 0 & 14 & 0 & 82 & 4 \\
\hline Gezondheidszorg & 26 & 0 & 0 & 0 & 0 & 1 & 0 & 1 & 36 & 0 & 55 & 6 \\
\hline Gedrag en maatschappij & 25 & 0 & 0 & 0 & 0 & 1 & 0 & 0 & 29 & 0 & 70 & 0 \\
\hline Taal en cultuur & 28 & 0 & 0 & 0 & 0 & 0 & 1 & 0 & 73 & 3 & 24 & 0 \\
\hline wo & 31 & 0 & 0 & 0 & 0 & $\mathbf{0}$ & 0 & 0 & 5 & $\mathbf{0}$ & 30 & 65 \\
\hline Landbouw & 30 & 0 & 0 & 0 & 0 & 1 & 0 & 0 & 7 & 0 & 24 & 68 \\
\hline Techniek & 23 & 0 & 0 & 0 & 0 & 0 & 0 & 0 & 2 & 0 & 23 & 75 \\
\hline Economie & 27 & 0 & 0 & 0 & 0 & 0 & 0 & 0 & 5 & 0 & 27 & 67 \\
\hline Gezondheidszorg & 47 & 0 & 0 & 0 & 0 & 0 & 0 & 0 & 2 & 0 & 15 & 83 \\
\hline Gedrag en maatschappij & 24 & 0 & 0 & 0 & 0 & 0 & 0 & 0 & 9 & 0 & 36 & 55 \\
\hline Taal en cultuur & 37 & 0 & 0 & 0 & 0 & 0 & 0 & 0 & 9 & 0 & 63 & 27 \\
\hline Recht en openbare orde & 30 & 0 & 0 & 0 & 0 & 0 & 0 & 0 & 2 & 0 & 27 & 72 \\
\hline Natuurwetenschappen & 48 & 0 & 0 & 0 & 0 & 0 & 0 & 0 & 3 & 0 & 32 & 65 \\
\hline Totaal & 60 & 1 & 0 & 0 & 7 & 26 & 5 & 6 & 35 & 0 & 17 & 2 \\
\hline
\end{tabular}


Tabel A2.2

Belangrijkste opleidingen van schoolverlaters die een vervolgopleiding zijn gaan volgen

HAVO

HBO Leraar basisonderwijs

VWO

WO Geneeskunde

WO Psychologie

VMBO theoretische leerweg

HAVO

VMBO economie

BOL BB Bedrijfsadministratie

VMBO gezondheidszorg

BOL BB Helpende welzijn

BOL ZB Sociaal-pedagogisch werk

BOL MKF Sociaal-pedagogisch werk

$B O L$ niveau 1/2 landbouw

BOL ZB Dierenzor

BOL ZB Vakbekw, medew. bosexploitatie/bos en natuurbeheer

BBL ZB Groene ruimte

BBL ZB Vakbekw, Hovenier

BOL ZB Groene ruimte

BOL ZB Plantenteelt

BOL ZB Akkerbouw

BOL ZB Loonwerk (plantenteelt)

BBL ZB Bloemschikken

BOL niveau $1 / 2$ techniek

BBL BB Autotechnicus

BBL ZB Eerste autotechnicus

BOL MKF Informatietechniek

BOL niveau $1 / 2$ economie

BBL ZB Zelfstandig werkend kok

BBL ZB Detailhandel/ambulante handel

$B O L$ niveau $1 / 2$ gezondheidszorg

BOL ZB Sociaal-pedagogisch werk

BBL ZB Verzorgende

BOL ZB Verzorgende

$B O L$ niveau 3/4 landbouw

HBO B Dier- en veehouderij

BOL niveau 3/4 techniek

HBO Bouwkunde

HBO Werktuigbouwkunde

HBO Elektrotechniek

BOL niveau $3 / 4$ economie

HBO Commerciele economie

HBO Management, economie en recht

BOL niveau $3 / 4$ gezondheidszorg

HBO Opleiding tot verpleegkundige

BOL MKF Verpleegkundige

BBL MKF Verpleegkundige

HBO Leraar basisonderwijs 
Tabel A2.2 (vervolg)

Belangrijkste opleidingen van schoolverlaters die een vervolgopleiding zijn gaan volgen

BOL niveau 3/4 gedrag en maatschappij

HBO Leraar basisonderwijs

HBO Sociaal pedagogische hulpverlening

HBO Pedagogiek

BBL niveau 1/2 landbouw

BBL ZB Vakbekw, Hovenier

BBL ZB Bloemschikken

BBL BB Landbouw

$B B L$ niveau $1 / 2$ techniek

BBL ZB Voortgezette timmerkracht

BBL ZB Constructie- en apparatenbouwer

$B B L$ niveau $1 / 2$ economie

BBL ZB Zelfstandig werkend kok

BBL ZB Zelfstandig werkend gastheer/-vrouw

BBL MKF Administratief-juridisch medewerker - openbaar bestuur

BOL BB Wegvervoer

BOL BB Bedrijfsadministratie

BBL AB Detailhandel/ambulante handel

BBL MKF Ondernemer/manager detailhandel

HBO Commerciele economie

$B B L$ niveau $1 / 2$ gezondheidszorg

BBL ZB Verzorgende bij inst. voor gezinsverz.

BBL niveau 3/4 landbouw

HBO Educatie en kennismanagement groene sector

BBL ZB Boomteelt

BBL niveau 3/4 techniek

HBO Algemene operationele technologie

BOL BB Schilder

BBL MKF Assistent-uitvoerder B\&U

BBL BB Primaire timmerkracht

HBO Elektrotechniek

BOL MKF Procestechniek

HBO Bouwkunde

20

15

8

7

7

6

BBL niveau 3/4 economie

HBO Commerciele economie

BBL Specialist Gespecialiseerd kok

BBL MKF Detailhandel/ambulante handel

BBL MKF Sociaal-pedagogisch werker

BBL Specialist ICT-beheerder

HBO Kort Logistiek Management

HBO Accountancy

HBO Small business en retail management

HBO B Makelaardij o.g. (3-jarig)

BBL niveau 3/4 gezondheidszorg

HBO Management

23

BBL MKF Verpleegkundige

18

$\mathrm{HBO}$ Opleiding tot verpleegkundige

$\mathrm{BOL} Z \mathrm{ZB}$ Verpleging en verzorging 
Tabel A2.2 (vervolg)

Belangrijkste opleidingen van schoolverlaters die een vervolgopleiding zijn gaan volgen

$B B L$ niveau 3/4 gedrag en maatschappij

HBO B Psychologie

HBO Leraar basisonderwijs

BBL MKF Sociaal-pedagogisch werk

HBO Maatschappelijk werk en dienstverlening

BBL MKF Verpleegkundige

HBO Communicatie

HBO Pedagogiek

HBO landbouw

WO Dierwetenschappen

WO Bedrijfskunde

HBO onderwijs

HBO Leraar speciaal onderwijs

WO Pedagogische wetenschappen

HBO Pedagogiek

HBO techniek

WO Bouwkunde

HBO economie

WO Bedrijfskunde

WO Nederlands recht

WO Bedrijfseconomie

WO Bedrijfseconomie Marketing

HBO gezondheidszorg

WO Gezondheidswetenschappen

HBO B Manuele Therapie

WO Bewegingswetenschappen

HBO gedrag en maatschappij

WO Pedagogische wetenschappen

HBO Leraar basisonderwijs

WO Nederlands recht

WO Psychologie

HBO taal en cultuur

HBO Kunst en cultuur

HBO Muziek vrije richting

WO landbouw

$\mathrm{AIO} / \mathrm{OIO}$

WO Kort Onderwijs

WO techniek

$\mathrm{AIO} / \mathrm{OIO}$

WO economie

Post-doct. beroepsopl. Accountant

Post-doct. beroepsopl. Registeraccountant

WO gezondheidszorg

$\mathrm{AlO} / \mathrm{OlO}$

Post-doct. beroepsopl. Medisch specialist (AGIO)

Post-doct. beroepsopl. Huisarts 
Tabel A2.2 (vervolg)

Belangrijkste opleidingen van schoolverlaters die een vervolgopleiding zijn gaan volgen

WO gedrag en maatschappij

$\mathrm{AlO} / \mathrm{OIO}$

WO Kort Onderwijs

Post-doct. Beroepsopl. Gezondheidszorgpsycholoog

WO taal en cultuur

WO Kort Onderwijs

$\mathrm{AIO} / \mathrm{OIO}$

WO recht en openbare orde

Post-doct. beroepsopl. Advocatuur

Post-doct. beroepsopl. Kandidaat notaris opleiding

9

Post-doct. beroepsopl. Belastingadviseur

$\mathrm{AIO} / \mathrm{OIO}$

WO natuurwetenschappen

$\mathrm{AIO} / \mathrm{OIO}$

WO Kort Onderwijs

WO Geneeskunde

Post-doct. beroepsopl. Klinische farmacologie

\section{Toelichting}

- In de tabel zijn alleen die opleidingen opgenomen die door ten minste $5 \%$ van de schoolverlaters worden gevolgd. 
Tabel A2.3

Oordeel van schoolverlaters over de aansluiting van de afgesloten opleiding met de vervolgopleiding

\begin{tabular}{|c|c|c|c|c|}
\hline Opleidingssector & $\begin{array}{r}\text { goed } \\
\%\end{array}$ & $\begin{array}{r}\text { voldoende } \\
\%\end{array}$ & $\begin{array}{r}\text { matig } \\
\%\end{array}$ & $\begin{array}{r}\text { slecht } \\
\%\end{array}$ \\
\hline HAVO/VWO & 43 & 42 & 12 & 3 \\
\hline HAVO & 40 & 44 & 12 & 3 \\
\hline VWO & 47 & 39 & 11 & 2 \\
\hline VMBO & 49 & 35 & 10 & 5 \\
\hline Theoretische leerweg & 48 & 37 & 11 & 4 \\
\hline Landbouw & 48 & 34 & 13 & 5 \\
\hline Techniek & 55 & 30 & 8 & 5 \\
\hline Economie & 42 & 37 & 14 & 7 \\
\hline Gezondheidszorg & 56 & 30 & 7 & 6 \\
\hline BOL niveau $1 / 2$ & 52 & 32 & 11 & 5 \\
\hline Landbouw & 41 & 50 & 2 & 6 \\
\hline Techniek & 49 & 30 & 18 & 4 \\
\hline Economie & 54 & 31 & 7 & 6 \\
\hline Gezondheidszorg & 51 & 32 & 14 & 2 \\
\hline BOL niveau $3 / 4$ & 36 & 37 & 18 & 9 \\
\hline Landbouw & 36 & 36 & 18 & 10 \\
\hline Techniek & 32 & 38 & 18 & 12 \\
\hline Economie & 35 & 38 & 18 & 9 \\
\hline Gezondheidszorg & 41 & 37 & 18 & 4 \\
\hline Gedrag en maatschappij & 39 & 36 & 19 & 6 \\
\hline BBL niveau $1 / 2$ & 65 & 22 & 9 & 2 \\
\hline Landbouw & 64 & 24 & 2 & 5 \\
\hline Techniek & 72 & 18 & 6 & 0 \\
\hline Economie & 50 & 32 & 13 & 4 \\
\hline Gezondheidszorg & 73 & 12 & 15 & 0 \\
\hline BBL niveau $3 / 4$ & 37 & 37 & 18 & 5 \\
\hline Landbouw & 42 & 26 & 28 & 5 \\
\hline Techniek & 32 & 54 & 7 & 6 \\
\hline Economie & 26 & 34 & 31 & 5 \\
\hline Gezondheidszorg & 45 & 49 & 3 & 0 \\
\hline Gedrag en maatschappij & 56 & 16 & 19 & 10 \\
\hline Totaal & 46 & 37 & 12 & 5 \\
\hline
\end{tabular}

Toelichting

Vraag in de enquête:

- Hoe is de aansluiting tussen de gevolgde [...] opleiding en deze vervolgopleiding? 
Tabel A2.4

Doorstroom van schoolverlaters naar kenniscentrum beroepsonderwijs bedrijfsleven

HAVO

OVDB

Ecabo

LOB HTV

Aequor

Bouwradius LOB

VBGI

KC Handel

VMBO theoretische leerweg

OVDB

Ecabo

LOB HTV

Kenteq

KC Handel

VMBO landbouw

Aequor

OVDB

LOB HTV

VMBO techniek

Kenteq

Bouwradius LOB

Innovam

SH\&M

VMBO economie

Ecabo

LOB HTV

KC Handel

OVDB

VMBO gezondheidszorg

OVDB

KOC Nederland

BOL niveau 1/2 landbouw

Aequor

BOL niveau $1 / 2$ techniek

Kenteq

Innovam

Ecabo

Vocar

BOL niveau 1/2 economie

Ecabo

LOB HTV

KC Handel

OVDB

BOL niveau $1 / 2$ gezondheidszorg

OVDB

KOC Nederland

BOL niveau 3/4 landbouw 
Tabel A2.4 (vervolg)

Doorstroom van schoolverlaters naar kenniscentrum beroepsonderwijs bedrijfsleven

BOL niveau 3/4 techniek

Kenteq

OVDB

VBGI

LOB HTV

Transport \& Logistiek

Ecabo

KC Handel

BOL niveau 3/4 economie

KC Handel

Ecabo

OVDB

LOB HTV

BOL niveau 3/4 gezondheidszorg

OVDB

KC Handel

KOC Nederland

BOL niveau 3/4 gedrag en maatschappij

OVDB

KC Handel

Ecabo

BBL niveau 1/2 landbouw

Aequor

$B B L$ niveau $1 / 2$ techniek

Bouwradius LOB

Kenteq

Savantis

Innovam

LOB HTV

BBL niveau 1/2 economie

LOB HTV

Ecabo

KC Handel

Transport \& Logistiek

BBL niveau 3/4 economie

LOB HTV

Ecabo

Bouwradius LOB

KC Handel

OVDB

Kenteq

Toelichting

- In de tabel zijn alleen die kenniscentra opgenomen die door ten minste $5 \%$ van de schoolverlaters worden gevolgd. 
Tabel A3.1

Werkloosheid en gemiddelde intredewerkloosheid van schoolverlaters die zich aanbieden op de arbeidsmarkt

\begin{tabular}{|c|c|c|c|c|c|c|c|c|}
\hline \multirow[t]{2}{*}{ Opleidingssector } & \multirow{2}{*}{$\begin{array}{r}\text { aanbieden op } \\
\text { arbeidsmarkt }\end{array}$} & werkloosheid & \multicolumn{4}{|c|}{ werkloos tijdens intredeperiode in klassen } & \multirow{2}{*}{\multicolumn{2}{|c|}{$\begin{array}{r}\text { intrede } \\
\text { werkloosheic } \\
\text { maander }\end{array}$}} \\
\hline & & $\%$ & $\begin{array}{r}0 \text { mnd. } \\
\%\end{array}$ & $\begin{array}{r}1-3 \text { mnd. } \\
\%\end{array}$ & $\begin{array}{r}4-6 \text { mnd. } \\
\%\end{array}$ & $\begin{array}{r}\text { 7-12 mnd., } \\
\%\end{array}$ & & \\
\hline HAVO/VWO & 6 & 17 & 84 & 12 & 4 & 0 & 1 & 0,6 \\
\hline HAVO & 8 & 18 & 84 & 11 & 4 & 0 & 2 & 0,7 \\
\hline VWO & 3 & 15 & 84 & 13 & 3 & 0 & 0 & 0,4 \\
\hline VMBO & 28 & 6 & 89 & 6 & 5 & 1 & 0 & 0,4 \\
\hline Theoretische leerweg & 11 & 12 & 87 & 7 & 5 & 1 & 0 & 0,5 \\
\hline Landbouw & 35 & 8 & 82 & 8 & 7 & 2 & 1 & 0,8 \\
\hline Techniek & 66 & 2 & 93 & 3 & 4 & 0 & 0 & 0,3 \\
\hline Economie & 35 & 9 & 88 & 10 & 2 & 0 & 0 & 0,2 \\
\hline Gezondheidszorg & 25 & 7 & 85 & 5 & 10 & 0 & 0 & 0,7 \\
\hline BOL niveau $1 / 2$ & 60 & 25 & 73 & 10 & 5 & 8 & 5 & 2,2 \\
\hline Landbouw & 65 & 21 & 55 & 27 & 6 & 10 & 2 & 2,3 \\
\hline Techniek & 59 & 23 & 75 & 9 & 6 & 5 & 5 & 2,1 \\
\hline Economie & 62 & 28 & 72 & 8 & 5 & 9 & 5 & 2,4 \\
\hline Gezondheidszorg & 55 & 19 & 73 & 12 & 3 & 8 & 5 & 1,9 \\
\hline BOL niveau $3 / 4$ & 51 & 11 & 77 & 11 & 7 & 4 & 2 & 1,2 \\
\hline Landbouw & 59 & 9 & 77 & 14 & 6 & 1 & 1 & 1,0 \\
\hline Techniek & 44 & 9 & 75 & 11 & 7 & 3 & 4 & 1,5 \\
\hline Economie & 46 & 12 & 71 & 14 & 10 & 5 & 1 & 1,5 \\
\hline Gezondheidszorg & 70 & 6 & 85 & 8 & 3 & 2 & 1 & 0,7 \\
\hline Gedrag en maatschappij & 48 & 16 & 78 & 10 & 5 & 6 & 1 & 1,1 \\
\hline BBL niveau $1 / 2$ & 92 & 7 & 89 & 6 & 3 & 2 & 1 & 0,7 \\
\hline Landbouw & 87 & 3 & 94 & 4 & 1 & 0 & 1 & 0,3 \\
\hline Techniek & 92 & 5 & 88 & 5 & 6 & 1 & 0 & 0,5 \\
\hline Economie & 89 & 10 & 83 & 11 & 2 & 2 & 2 & 0,9 \\
\hline Gezondheidszorg & 98 & 8 & 96 & 0 & 0 & 2 & 2 & 1,0 \\
\hline
\end{tabular}


Tabel A3.1 (vervolg)

Werkloosheid en gemiddelde intredewerkloosheid van schoolverlaters die zich aanbieden op de arbeidsmarkt

\begin{tabular}{|c|c|c|c|c|c|c|c|c|}
\hline \multirow[t]{2}{*}{ Opleidingssector } & $\begin{array}{l}\text { aanbieden op } \\
\text { arbeidsmarkt }\end{array}$ & werkloosheid & \multicolumn{4}{|c|}{ werkloos tijdens intredeperiode in klassen } & \multirow{2}{*}{\multicolumn{2}{|c|}{$\begin{array}{r}\text { intrede } \\
\text { werkloosheid } \\
\text { maanden }\end{array}$}} \\
\hline & 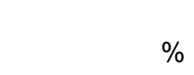 & $\%$ & $\begin{array}{r}0 \text { mnd. } \\
\%\end{array}$ & $\begin{array}{r}1-3 \text { mnd. } \\
\%\end{array}$ & $\begin{array}{r}4-6 \text { mnd. } \\
\%\end{array}$ & $\begin{array}{r}\text { 7-12 mnd., } \\
\%\end{array}$ & & \\
\hline BBL niveau $3 / 4$ & 91 & 4 & 95 & 2 & 1 & 1 & 1 & 0,4 \\
\hline Landbouw & 95 & 2 & 91 & 7 & 2 & 1 & 0 & 0,3 \\
\hline Techniek & 92 & 1 & 96 & 2 & 0 & 1 & 0 & 0,2 \\
\hline Economie & 80 & 9 & 89 & 3 & 2 & 4 & 1 & 0,8 \\
\hline Gezondheidszorg & 97 & 4 & 99 & 1 & 0 & 0 & 0 & 0,0 \\
\hline Gedrag en maatschappij & 84 & 4 & 87 & 4 & 3 & 0 & 6 & 1,5 \\
\hline HBO & 81 & 6 & 75 & 13 & 6 & 4 & 2 & 1,2 \\
\hline Landbouw & 79 & 8 & 68 & 13 & 10 & 6 & 3 & 1,8 \\
\hline Onderwijs & 91 & 4 & 83 & 10 & 4 & 2 & 1 & 0,8 \\
\hline Techniek & 75 & 6 & 72 & 14 & 7 & 4 & 2 & 1,4 \\
\hline Economie & 75 & 7 & 74 & 14 & 7 & 4 & 2 & 1,2 \\
\hline Gezondheidszorg & 89 & 5 & 79 & 13 & 5 & 3 & 1 & 0,9 \\
\hline Gedrag en maatschappij & 87 & 6 & 74 & 13 & 5 & 5 & 3 & 1,5 \\
\hline Taal en cultuur & 84 & 13 & 71 & 9 & 9 & 7 & 4 & 1,9 \\
\hline wo & 94 & 5 & 67 & 15 & 9 & 6 & 3 & 1,8 \\
\hline Landbouw & 96 & 6 & 60 & 15 & 13 & 8 & 3 & 2,2 \\
\hline Techniek & 97 & 4 & 62 & 17 & 11 & 8 & 3 & 2,2 \\
\hline Economie & 97 & 4 & 68 & 15 & 11 & 5 & 1 & 1,5 \\
\hline Gezondheidszorg & 90 & 3 & 74 & 16 & 6 & 3 & 1 & 1,0 \\
\hline Gedrag en maatschappij & 94 & 7 & 65 & 15 & 9 & 7 & 4 & 2,0 \\
\hline Taal en cultuur & 88 & 10 & 63 & 15 & 9 & 7 & 5 & 2,2 \\
\hline Recht en openbare orde & 95 & 4 & 72 & 11 & 8 & 6 & 3 & 1,6 \\
\hline Natuurwetenschappen & 89 & 5 & 68 & 15 & 9 & 5 & 2 & 1,6 \\
\hline
\end{tabular}


Tabel A3.1 (vervolg)

Werkloosheid en gemiddelde intredewerkloosheid van schoolverlaters die zich aanbieden op de arbeidsmarkt

\begin{tabular}{|c|c|c|c|c|c|c|c|c|}
\hline \multirow[t]{2}{*}{ Opleidingssector } & $\begin{array}{c}\text { aanbieden op } \\
\text { arbeidsmarkt }\end{array}$ & werkloosheid & \multicolumn{4}{|c|}{ werkloos tijdens intredeperiode in klassen } & & \multirow{2}{*}{$\begin{array}{r}\text { intrede- } \\
\text { werkloosheid } \\
\text { maanden }\end{array}$} \\
\hline & $\%$ & $\%$ & $\begin{array}{r}0 \text { mnd. } \\
\%\end{array}$ & $\begin{array}{r}1-3 \text { mnd. } \\
\%\end{array}$ & $\begin{array}{r}4-6 \text { mnd. } \\
\%\end{array}$ & $\begin{array}{r}\text { 7-12 mnd., } \\
\%\end{array}$ & $\begin{array}{r}\geq 13 \text { mnd. } \\
\%\end{array}$ & \\
\hline Totaal & 50 & 8 & 81 & 9 & 5 & 3 & 2 & 1,0 \\
\hline
\end{tabular}

Toelichting

- Het werkloosheidspercentage heeft betrekking op de werkloze beroepsbevolking: schoolverlaters zonder werk (of met werk van minder dan 12 uur per week) die op zoek zijn naar betaald werk. Daarbij is tevens als voorwaarde gesteld dat de maatschappelijke positie niet scholier of student is.

- De intredewerkloosheid betreft het aantal maanden dat schoolverlaters zichzelf als werkloos beschouwen. 
Tabel A3.2

Aard van het dienstverband van werkende schoolverlaters

\begin{tabular}{|c|c|c|c|c|c|c|}
\hline Opleidingssector & $\begin{array}{r}\text { leer/werk- } \\
\text { overeenkomst } \\
\%\end{array}$ & $\begin{array}{r}\text { uitzend-, } \\
\text { oproepkracht } \\
\%\end{array}$ & $\begin{array}{r}\text { loondienst } \\
\text { werkgever } \\
\%\end{array}$ & $\begin{array}{r}\text { gesubsidieerde } \\
\text { arbeid (wiw) } \\
\%\end{array}$ & $\begin{array}{r}\text { bedrijf ouders/ } \\
\text { partner } \\
\%\end{array}$ & $\begin{array}{r}\text { eigen bedrijf/ } \\
\text { free-lance } \\
\%\end{array}$ \\
\hline HAVO/VWO & 33 & 5 & 57 & 0 & 2 & 3 \\
\hline HAVO & 35 & 4 & 57 & 0 & 3 & 2 \\
\hline VWO & 27 & 7 & 60 & 0 & 0 & 7 \\
\hline VMBO & 54 & 4 & 40 & 0 & 2 & 0 \\
\hline Theoretische leerweg & 51 & 6 & 40 & 0 & 1 & 1 \\
\hline Landbouw & 58 & 4 & 36 & 0 & 2 & 0 \\
\hline Techniek & 57 & 2 & 38 & 0 & 2 & 0 \\
\hline Economie & 46 & 6 & 45 & 0 & 2 & 1 \\
\hline Gezondheidszorg & 52 & 4 & 44 & 0 & 0 & 0 \\
\hline BOL niveau $1 / 2$ & 30 & 6 & 59 & 1 & 1 & 3 \\
\hline Landbouw & 16 & 26 & 58 & 0 & 0 & 0 \\
\hline Techniek & 39 & 6 & 54 & 0 & 0 & 1 \\
\hline Economie & 33 & 7 & 54 & 2 & 2 & 3 \\
\hline Gezondheidszorg & 18 & 3 & 74 & 1 & 0 & 4 \\
\hline BOL niveau 3/4 & 7 & 7 & 83 & 0 & 1 & 2 \\
\hline Landbouw & 8 & 9 & 74 & 0 & 4 & 4 \\
\hline Techniek & 5 & 7 & 84 & 0 & 0 & 4 \\
\hline Economie & 6 & 9 & 83 & 0 & 1 & 1 \\
\hline Gezondheidszorg & 11 & 3 & 85 & 0 & 1 & 1 \\
\hline Gedrag en maatschappij & 6 & 6 & 87 & 0 & 0 & 0 \\
\hline BBL niveau $1 / 2$ & 21 & 2 & 75 & 0 & 0 & 1 \\
\hline Landbouw & 15 & 2 & 82 & 2 & 0 & 0 \\
\hline Techniek & 25 & 3 & 70 & 0 & 1 & 1 \\
\hline Economie & 23 & 1 & 75 & 0 & 0 & 1 \\
\hline Gezondheidszorg & 14 & 0 & 83 & 1 & 0 & 2 \\
\hline
\end{tabular}


Tabel A3.2 (vervolg)

Aard van het dienstverband van werkende schoolverlaters

\begin{tabular}{|c|c|c|c|c|c|c|}
\hline Opleidingssector & $\begin{array}{r}\text { leer/werk- } \\
\text { overeenkomst } \\
\%\end{array}$ & $\begin{array}{r}\text { uitzend-, } \\
\text { oproepkracht } \\
\%\end{array}$ & $\begin{array}{r}\text { loondienst } \\
\text { werkgever } \\
\%\end{array}$ & $\begin{array}{r}\text { gesubsidieerde } \\
\text { arbeid (wiw) } \\
\%\end{array}$ & $\begin{array}{r}\text { bedrijf ouders/ } \\
\text { partner } \\
\%\end{array}$ & $\begin{array}{r}\text { eigen bedrijf/ } \\
\text { free-lance } \\
\%\end{array}$ \\
\hline BBL niveau $3 / 4$ & 4 & 1 & 94 & 0 & 0 & 1 \\
\hline Landbouw & 4 & 1 & 90 & 0 & 1 & 3 \\
\hline Techniek & 8 & 0 & 90 & 0 & 1 & 2 \\
\hline Economie & 2 & 5 & 90 & 0 & 0 & 3 \\
\hline Gezondheidszorg & 3 & 0 & 97 & 0 & 0 & 0 \\
\hline Gedrag en maatschappij & 3 & 2 & 92 & 3 & 0 & 0 \\
\hline HBO & 0 & 8 & 89 & 0 & 0 & 3 \\
\hline Landbouw & 0 & 12 & 81 & 0 & 3 & 4 \\
\hline Onderwijs & 0 & 5 & 95 & 0 & 0 & 1 \\
\hline Techniek & 0 & 7 & 90 & 0 & 0 & 3 \\
\hline Economie & 0 & 10 & 87 & 0 & 0 & 3 \\
\hline Gezondheidszorg & 0 & 5 & 91 & 0 & 0 & 4 \\
\hline Gedrag en maatschappij & 0 & 9 & 90 & 0 & 0 & 1 \\
\hline Taal en cultuur & 0 & 5 & 64 & 0 & 0 & 31 \\
\hline wo & 0 & 5 & 92 & 0 & 0 & 3 \\
\hline Landbouw & 0 & 6 & 92 & 0 & 0 & 2 \\
\hline Techniek & 0 & 3 & 92 & 0 & 0 & 4 \\
\hline Economie & 0 & 3 & 94 & 0 & 0 & 2 \\
\hline Gezondheidszorg & 0 & 2 & 94 & 0 & 0 & 4 \\
\hline Gedrag en maatschappij & 0 & 7 & 91 & 0 & 0 & 2 \\
\hline Taal en cultuur & 0 & 9 & 84 & 0 & 0 & 7 \\
\hline Recht en openbare orde & 0 & 4 & 94 & 0 & 0 & 2 \\
\hline Natuurwetenschappen & 0 & 7 & 91 & 0 & 0 & 2 \\
\hline Totaal & 14 & 5 & 78 & 0 & 1 & 2 \\
\hline
\end{tabular}


Tabel A3.3

Percentage werkende schoolverlaters met een flexibele aanstelling

Opleidingssector

HAVO/VWO

HAVO

VWO

VMBO

Landbouw

45

Techniek

Economie

Gezondheidszorg

BOL niveau 1/2

Landbouw

Techniek

50

Economie

46

Gezondheidszorg

BOL niveau 3/4

Landbouw

Techniek

42

Economie

Gezondheidszorg

Gedrag en maatschappij

BBL niveau 1/2

Landbouw

Techniek

Economie

Gezondheidszorg

BBL niveau 3/4

Landbouw

Techniek

Economie

Gezondheidszorg

Gedrag en maatschappij

HBO

Landbouw

Onderwijs

Techniek

Economie

Gezondheidszorg

Gedrag en maatschappij

Taal en cultuur

Landbouw

Techniek

Economie

Gezondheidszorg

Gedrag en maatschappij

Taal en cultuur

52

Recht en openbare orde 
Tabel A3.3 (vervolg)

Percentage werkende schoolverlaters met een flexibele aanstelling

Opleidingssector

Totaal

38

Toelichting

- Een flexibele aanstelling betreft een aanstelling als uitzendkracht, oproepkracht e.d. of een aanstelling in tijdelijke dienst. 
Tabel A3.4

Belangrijkste bedrijfsgroepen waarin schoolverlaters werkzaam zijn

HAVO

$\begin{array}{ll}\text { Gezondheidszorg } & 17\end{array}$

Niet-gespec. detailh. in winkel $\quad 12$

$\begin{array}{ll}\text { Overheidsdienst. } & 10\end{array}$

Detailh. farmac./med. art./parfum/cosmet. in winkel $\quad 6$

Ov. gespec. detailh. in winkel $\quad 6$

$\begin{array}{ll}\text { Restaurants/cafetaria's/snackbars ed } & 5\end{array}$

VWO

Rechtsk. dienstverl./account./belastingconsul./holdings ed $\quad 21$

Gezondheidszorg 29

$\begin{array}{ll}\text { Verzekeringsw./pensioenfonds. (excl. verpl. soc.verzek.) } & 8\end{array}$

Openbaar bestuur $\quad 6$

$\begin{array}{ll}\text { Restaurants/cafetaria's/snackbars ed } & 5 \\ \text { Welzijnszorg } & 5\end{array}$

VMBO theoretische leerweg

Niet-gespec. detailh. in winkel 16

Gezondheidszorg $\quad 11$

Restaurants/cafetaria's/snackbars ed $\quad 8$

$\begin{array}{ll}\text { Ov. dienstverlening } & 8\end{array}$

$\begin{array}{ll}\text { Ov. gespec. detailh. in winkel } & 7\end{array}$

Overheidsdienst. $\quad 6$

Bouwinstallatie $\quad 5$

VMBO landbouw

$\begin{array}{ll}\text { Ov. gespec. detailh. in winkel } & 20\end{array}$

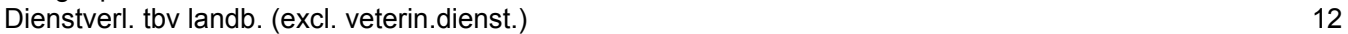

Niet-gespec. detailh. in winkel $\quad 8$

Burgerl./utilit.;grond-/water-/wegenb. (excl. grondverz.)

Ov. dienstverlening $\quad 6$

VMBO techniek

Afwerken gebouwen $\quad 19$

$\begin{array}{ll}\text { Bouwinstallatie } & 17\end{array}$

Handel in/repar. auto's (1) 12

Bouwnijverheid 8

VMBO economie

$\begin{array}{ll}\text { Ov. gespec. detailh. in winkel } & 23\end{array}$

Restaurants/cafetaria's/snackbars ed 11

$\begin{array}{ll}\text { Niet-gespec. detailh. in winkel } & 9\end{array}$

$\begin{array}{ll}\text { Gespec. detailh. voed.-/genotmid. in winkel } & 7\end{array}$

Hotels/pensions/conferentie-oorden $\quad 6$

VMBO gezondheidszorg

Welzijnszorg

Ov. dienstverlening $\quad 26$

Ov. gespec. detailh. in winkel $\quad 14$

Niet-gespec. detailh. in winkel $\quad 8$

Restaurants/cafetaria's/snackbars ed $\quad 5$

BOL niveau 1/2 landbouw

Ov. gespec. detailh. in winkel

Dienstverl. tbv landb. (excl. veterin.dienst.)

Vervaard. prod. beton/cement/gips $\quad 6$

Post-/koeriersdiensten $\quad 6$

Bouwrijp maken terreinen $\quad 5$

Welzijnszorg 
Tabel A3.4 (vervolg)

Belangrijkste bedrijfsgroepen waarin schoolverlaters werkzaam zijn

BOL niveau $1 / 2$ techniek

Handel in/repar. auto's (1)

Bouwinstallatie

BOL niveau $1 / 2$ economie

Restaurants/cafetaria's/snackbars ed

$\begin{array}{ll}\text { Ov. gespec. detailh. in winkel } & 14\end{array}$

Overheidsdienst.

Niet-gespec. detailh. in winkel

Hotels/pensions/conferentie-oorden

BOL niveau $1 / 2$ gezondheidszorg

Welzijnszorg

Ov. dienstverlening

BOL niveau 3/4 landbouw

$\begin{array}{ll}\text { Dienstverl. tbv landb. (excl. veterin.dienst.) } & 20\end{array}$

$\begin{array}{lr}\text { Ov. gespec. detailh. in winkel } & 19\end{array}$

Akker-/tuinbouw

Fokken/houden dieren

BOL niveau $3 / 4$ techniek

Bouwinstallatie

Ov. gespec. detailh. in winkel

Burgerl./utilit.;grond-/water-/wegenb. (excl. grondverz.)

BOL niveau 3/4 economie

Rechtsk. dienstverl./account./belastingconsul./holdings ed

Ov. gespec. detailh. in winkel

Niet-gespec. detailh. in winkel

Hotels/pensions/conferentie-oorden

Reisorgan./-bemid.;informatieverstrek. op gebied toerisme

BOL niveau $3 / 4$ gezondheidszorg

Gezondheidszorg

Welzijnszorg

Detailh. farmac./med. art./parfum/cosmet. in winkel

Ov. dienstverlening

BOL niveau 3/4 gedrag en maatschappij

Welzijnszorg

Primair onderwijs voor leerplichtingen en speciaal onderwijs

BBL niveau 1/2 landbouw

Dienstverl. tbv landb. (excl. veterin.dienst.)

Vervaard. ov. goederen n.e.g. 22

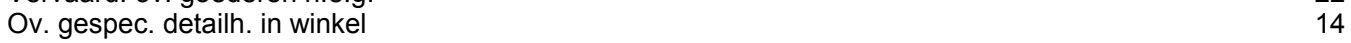

Akker-/tuinbouw

BBL niveau $1 / 2$ techniek

Burgerl./utilit.;grond-/water-/wegenb. (excl. grondverz.) 20

Afwerken gebouwen $\quad 14$

$\begin{array}{lr}\text { Bouwinstallatie } & 13\end{array}$

Vervoer over weg $\quad 13$

$\begin{array}{lr}\text { Handel in/repar. auto's (1) } & 7\end{array}$ 
Tabel A3.4 (vervolg)

Belangrijkste bedrijfsgroepen waarin schoolverlaters werkzaam zijn

BBL niveau $1 / 2$ economie

$\begin{array}{ll}\text { Restaurants/cafetaria's/snackbars ed } & 27\end{array}$

$\begin{array}{ll}\text { Ov. gespec. detailh. in winkel } & 20\end{array}$

Niet-gespec. detailh. in winkel $\quad 14$

Hotels/pensions/conferentie-oorden $\quad 6$

Laad-/los-/overslagactiv./opslag 6

BBL niveau $1 / 2$ gezondheidszorg

Welzijnszorg

Gezondheidszorg

BBL niveau 3/4 landbouw

Dienstverl. tbv landb. (excl. veterin.dienst.)

$\begin{array}{lr}\text { Ov. gespec. detailh. in winkel } & 19\end{array}$

Openbaar bestuur

Akker-/tuinbouw

Vervaard. zuivelprodukten

BBL niveau 3/4 techniek

Handel in/repar. auto's (1)

Afwerken gebouwen

Bouwinstallatie

Handel in/repar. auto's (2)

BBL niveau $3 / 4$ economie

Restaurants/cafetaria's/snackbars ed

$\begin{array}{ll}\text { Niet-gespec. detailh. in winkel } & 15\end{array}$

$\begin{array}{lr}\text { Ov. gespec. detailh. in winkel } & 12\end{array}$

$\begin{array}{lr}\text { Hotels/pensions/conferentie-oorden } & 8 \\ \text { Grooth. voedings-/genotmid. } & 6\end{array}$

BBL niveau $3 / 4$ gezondheidszorg

Welzijnszorg

Gezondheidszorg

Ov. dienstverlening

BBL niveau $3 / 4$ gedrag en maatschappij

Welzijnszorg

Primair onderwijs voor leerplichtingen en speciaal onderwijs

HBO landbouw

Architecten-/ingenieurs-/ov. techn.ontw.-/teken-/adviesbur.

Openbaar bestuur

Vervaard. diervoeder

Grooth. landbouwprod./lev. dieren

HBO onderwijs

Primair onderwijs voor leerplichtingen en speciaal onderwijs

HBO techniek

Architecten-/ingenieurs-/ov. techn.ontw.-/teken-/adviesbur.

Ontwikkelen, produceren en uitgeven van software; softwareco

Burgerl./utilit.;grond-/water-/wegenb. (excl. grondverz.)

Gezondheidszorg

HBO economie

Rechtsk. dienstverl./account./belastingconsul./holdings ed

Geldscheppende financ. instell.

Uitzendbur./uitleenbedr./arbeidsbemid./testen/werven/select. 
Tabel A3.4 (vervolg)

Belangrijkste bedrijfsgroepen waarin schoolverlaters werkzaam zijn

HBO gezondheidszorg

Gezondheidszorg

Welzijnszorg

HBO gedrag en maatschappij

Welzijnszorg

Gezondheidszorg

Uitzendbur./uitleenbedr./arbeidsbemid./testen/werven/select.

HBO taal en cultuur

Overig amusement/kunst

Reklamebureaus ed

Secundair onderwijs en educatie

\section{WO landbouw}

Tertiair onderwijs

Natuurwet. speur-/ontwikkelingsw.

Openbaar bestuur

Gezondheidszorg

Architecten-/ingenieurs-/ov. techn.ontw.-/teken-/adviesbur.

WO techniek

Architecten-/ingenieurs-/ov. techn.ontw.-/teken-/adviesbur.

Tertiair onderwijs

WO economie

Rechtsk. dienstverl./account./belastingconsul./holdings ed Geldscheppende financ. instell.

Tertiair onderwijs

WO gezondheidszorg

Gezondheidszorg

Tertiair onderwijs

Welzijnszorg

WO gedrag en maatschappij

Gezondheidszorg

Welzijnszorg

Tertiair onderwijs

Openbaar bestuur

Rechtsk. dienstverl./account./belastingconsul./holdings ed

WO taal en cultuur

Tertiair onderwijs

Secundair onderwijs en educatie

Uitgeverijen

Openbaar bestuur

WO recht en openbare orde

Rechtsk. dienstverl./account./belastingconsul./holdings ed

Openbaar bestuur 
Tabel A3.4 (vervolg)

Belangrijkste bedrijfsgroepen waarin schoolverlaters werkzaam zijn

WO natuurwetenschappen

Tertiair onderwijs

Detailh. farmac./med. art./parfum/cosmet. in winkel

Gezondheidszorg

Natuurwet. speur-/ontwikkelingsw.

\section{Toelichting}

- De bedrijven waarin de schoolverlaters werkzaam zijn, zijn geclassificeerd volgens de Standaard Bedrijfs Indeling van het CBS. Op het hier gepresenteerde niveau van bedrijfsgroepen worden in totaal 211 categorieën onderscheiden.

- In de tabel zijn alleen die bedrijfsgroepen weergegeven waarin ten minste $5 \%$ van de schoolverlaters werkzaam is. 
Tabel A3.5

Belangrijkste beroepsgroepen waarin schoolverlaters werkzaam zijn

HAVO

Verkopers

Verpleeghulpen en leerling-verpleegkundigen

Hulpkrachten horeca en verzorging

Receptionisten en administratieve employés

Aspirant politieagenten, soldaten en beveiligingshulpkrachten

11

10

8

VWO

Boekhouders en secretaresses

Hulpkrachten horeca en verzorging

Assistent accountants

Commercieel employés

Medisch analisten

VMBO theoretische leerweg

Verkopers

Hulpkrachten horeca en verzorging

Aspirant politieagenten, soldaten en beveiligingshulpkrachten

Verzorgend personeel

Verpleeghulpen en leerling-verpleegkundigen

VMBO landbouw

Verkopers

Agrarische arbeider

Hulpkrachten horeca en verzorging

VMBO techniek

Bouwvakkers

Aannemers en installateurs

Monteurs

Assembleurs

VMBO economie

Verkopers

Hulpkrachten horeca en verzorging

Laders en lossers

Receptionisten en administratieve employés

Verzorgend personeel

Bouwvakkers

Bakkers en slagers

\section{VMBO gezondheidszorg}

Verkopers

Verzorgend personeel

\section{BOL niveau 1/2 landbouw}

Verkopers

Agrarische arbeider

Agrarische bedrijfshoofden

Chauffeurs

Bouwvakkers

Productieplanners

Interieurverzorger 
Tabel A3.5 (vervolg)

Belangrijkste beroepsgroepen waarin schoolverlaters werkzaam zijn

BOL niveau $1 / 2$ techniek

Elektromonteurs

Bouwvakkers

Assembleurs

Metaalarbeiders

Monteurs en controleurs elektrotechnische producten

Mechanisch operators

BOL niveau $1 / 2$ economie

Hulpkrachten horeca en verzorging $\quad 22$

$\begin{array}{ll}\text { Aspirant politieagenten, soldaten en beveiligingshulpkrachten } & 11\end{array}$

Receptionisten en administratieve employés

BOL niveau $1 / 2$ gezondheidszorg

Verzorgend personeel

Hulpkrachten horeca en verzorging

Interieurverzorger

Verpleeghulpen en leerling-verpleegkundigen

BOL niveau 3/4 landbouw

Agrarische arbeider

Verkopers

Agrarische bedrijfshoofden

Agrarische vakkrachten

BOL niveau 3/4 techniek

Monteurs

Aannemers en installateurs

Elektromonteurs

Programmeurs

BOL niveau 3/4 economie

Boekhouders en secretaresses

Receptionisten en administratieve employés

Commercieel employés

Verkopers

BOL niveau $3 / 4$ gezondheidszorg

Verplegenden en doktersassistenten

Verzorgend personeel

31

Apothekersassistenten en medisch laboranten

Verpleeghulpen en leerling-verpleegkundigen

BOL niveau $3 / 4$ gedrag en maatschappij

Verzorgend personeel

Activiteitenbegeleiders en medewerkers arbeidsbemiddeling

Hulpkrachten horeca en verzorging

$B B L$ niveau 1/2 landbouw

Agrarische arbeider 
Tabel A3.5 (vervolg)

Belangrijkste beroepsgroepen waarin schoolverlaters werkzaam zijn

BBL niveau 1/2 techniek

Aannemers en installateurs

Bouwvakkers

Chauffeurs

Monteurs

BBL niveau 1/2 economie

Verkopers

Hulpkrachten horeca en verzorging

Verzorgend personeel

Laders en lossers

Chauffeurs

Aspirant politieagenten, soldaten en beveiligingshulpkrachten

BBL niveau $1 / 2$ gezondheidszorg

Verzorgend personeel

Hulpkrachten horeca en verzorging

Ziekenverzorgenden

Verpleeghulpen en leerling-verpleegkundigen

BBL niveau 3/4 landbouw

Agrarische arbeider

Agrarische vakkrachten

Verkopers

Agrarische bedrijfshoofden

Procesoperators

BBL niveau 3/4 techniek

Monteurs

Aannemers en installateurs

Bouwvakkers

Bankwerkers en lassers

BBL niveau 3/4 economie

Verzorgend personeel

Verkopers

Winkeliers

Hulpkrachten horeca en verzorging

Boekhouders en secretaresses

Receptionisten en administratieve employés

Commercieel employés

BBL niveau $3 / 4$ gezondheidszorg

Verzorgend personeel

BBL niveau $3 / 4$ gedrag en maatschappij 
Tabel A3.5 (vervolg)

Belangrijkste beroepsgroepen waarin schoolverlaters werkzaam zijn

HBO landbouw

Milieuhygienisten en agrarisch vertegenwoordigers $\quad 21$

Commercieel employés

Organisatie-adviseurs

Agrarische bedrijfshoofden

Commercieel medewerkers

HBO onderwijs

Leraar basisonderwijs

Docenten talen en expressie

HBO techniek

Systeemanalisten

Architecten en bouwkundig projectleiders

We rktuigbouwkundig ontwerpers en hoofden technische dienst

Technisch systeemanalisten

Technisch analisten

HBO economie

Commercieel medewerkers

Commercieel employés

Assistent accountants

HBO gezondheidszorg

Therapeuten en verpleegkundigen

Verplegenden en doktersassistenten

HBO gedrag en maatschappij

Sociaal-cultureel werkers

Verzorgend personeel

Activiteitenbegeleiders en medewerkers arbeidsbemiddeling

HBO taal en cultuur

Kunstenaars

Docenten talen en expressie

Verkopers

\section{WO landbouw}

Natuurwetenschappers $\quad 12$

Landbouwkundigen $\quad 10$

Materiaalkundigen

Commercieel medewerkers

Milieuhygienisten en agrarisch vertegenwoordigers

WO techniek

Weg- en waterbouwkundigen

Materiaalkundigen

Architecten en bouwkundig projectleiders

Werktuigbouwkundigen

Organisatiedeskundigen

Systeemanalisten

Elektrotechnici 
Tabel A3.5 (vervolg)

Belangrijkste beroepsgroepen waarin schoolverlaters werkzaam zijn

\section{WO economie}

$\begin{array}{ll}\text { Commercieel medewerkers } & 19\end{array}$

Assistent accountants $\quad 14$

$\begin{array}{lr}\text { Organisatiedeskundigen } & 10\end{array}$

$\begin{array}{lr}\text { Economen } & 8\end{array}$

$\begin{array}{ll}\text { Organisatie-adviseurs } & 7\end{array}$

Accountants

WO gezondheidszorg

Artsen

WO gedrag en maatschappij

$\begin{array}{ll}\text { Sociaal-wetenschappelijk onderzoekers } & 20\end{array}$

Onderwijskundigen en pedagogen $\quad 11$

$\begin{array}{ll}\text { Sociaal-cultureel werkers } & 8\end{array}$

Commercieel medewerkers $\quad 5$

WO taal en cultuur

Taalkundigen

Commercieel medewerkers

Docenten letteren (1e gr. en WO)

8

Docenten talen en expressie

WO recht en openbare orde

Juristen

Juridisch, bestuurlijk medewerkers

WO natuurwetenschappen

Natuurwetenschappers

Toelichting

- De beroepen waarin de schoolverlaters werkzaam zijn, zijn geclassificeerd volgens de Standaard Beroepenclassificatie 1992 van het CBS. Binnen de elementaire beroepen is hierbij door het ROA een nader onderscheid gemaakt. Bovendien zijn de namen van de beroepen verduidelijkt. Op het hier gepresenteerde niveau van beroepsgroepen worden in totaal 127 categorieën onderscheiden.

- In de tabel zijn alleen die beroepsgroepen weergegeven waarin ten minste $5 \%$ van de schoolverlaters werkzaam is. 
Tabel A3.6

Grootte van de organisatie waarin schoolverlaters werkzaam zijn

\begin{tabular}{|c|c|c|c|c|c|}
\hline Opleidingssector & $\begin{array}{r}1 \text { pers } \\
\%\end{array}$ & $\begin{array}{r}2 \mathrm{t} / \mathrm{m} 9 \\
\text { pers } \\
\%\end{array}$ & $\begin{array}{r}10 \mathrm{t} / \mathrm{m} 49 \\
\text { pers } \\
\%\end{array}$ & $\begin{array}{r}50 \mathrm{t} / \mathrm{m} 99 \\
\text { pers } \\
\%\end{array}$ & $\begin{array}{r}\geq 100 \\
\text { pers } \\
\%\end{array}$ \\
\hline HAVO/VWO & 1 & 18 & 19 & 7 & 55 \\
\hline HAVO & & 17 & 23 & 5 & 55 \\
\hline VWO & 2 & 21 & 5 & 15 & 57 \\
\hline VMBO & 1 & 27 & 33 & 9 & 30 \\
\hline Theoretische leerweg & & 23 & 29 & 7 & 41 \\
\hline Landbouw & 2 & 29 & 36 & 7 & 26 \\
\hline Techniek & 1 & 31 & 32 & 10 & 26 \\
\hline Economie & 3 & 21 & 46 & 6 & 24 \\
\hline Gezondheidszorg & 2 & 26 & 20 & 9 & 43 \\
\hline BOL niveau $1 / 2$ & 1 & 22 & 21 & 12 & 44 \\
\hline Landbouw & & 35 & 37 & 16 & 12 \\
\hline Techniek & & 26 & 25 & 21 & 29 \\
\hline Economie & 1 & 21 & 24 & 12 & 43 \\
\hline Gezondheidszorg & 1 & 18 & 11 & 6 & 64 \\
\hline BOL niveau 3/4 & 1 & 17 & 26 & 9 & 46 \\
\hline Landbouw & 5 & 42 & 26 & 6 & 22 \\
\hline Techniek & 2 & 17 & 25 & 11 & 45 \\
\hline Economie & 1 & 17 & 32 & 11 & 40 \\
\hline Gezondheidszorg & 1 & 16 & 22 & 6 & 55 \\
\hline Gedrag en maatschappij & 2 & 8 & 24 & 9 & 58 \\
\hline BBL niveau $1 / 2$ & 1 & 17 & 25 & 12 & 45 \\
\hline Landbouw & 1 & 29 & 18 & 9 & 42 \\
\hline Techniek & 1 & 21 & 30 & 17 & 31 \\
\hline Economie & & 19 & 34 & 9 & 38 \\
\hline Gezondheidszorg & & 2 & 8 & 8 & 82 \\
\hline BBL niveau 3/4 & 1 & 16 & 16 & 9 & 58 \\
\hline Landbouw & 1 & 35 & 24 & 5 & 35 \\
\hline Techniek & 2 & 37 & 29 & 6 & 27 \\
\hline Economie & 2 & 24 & 33 & 12 & 29 \\
\hline Gezondheidszorg & & 8 & 4 & 10 & 78 \\
\hline Gedrag en maatschappij & & 3 & 20 & 10 & 68 \\
\hline HBO & 2 & 9 & 19 & 9 & 62 \\
\hline Landbouw & 2 & 13 & 19 & 13 & 54 \\
\hline Onderwijs & 0 & 2 & 33 & 11 & 54 \\
\hline Techniek & 1 & 9 & 20 & 9 & 60 \\
\hline Economie & 1 & 9 & 16 & 8 & 65 \\
\hline Gezondheidszorg & 2 & 24 & 13 & 4 & 57 \\
\hline Gedrag en maatschappij & 0 & 3 & 9 & 8 & 80 \\
\hline Taal en cultuur & 19 & 15 & 24 & 11 & 31 \\
\hline wo & 1 & 7 & 15 & 6 & 71 \\
\hline Landbouw & & 6 & 15 & 6 & 73 \\
\hline Techniek & 2 & 8 & 17 & 6 & 68 \\
\hline Economie & 0 & 4 & 9 & 4 & 82 \\
\hline Gezondheidszorg & 0 & 11 & 9 & 3 & 76 \\
\hline Gedrag en maatschappij & 1 & 6 & 13 & 8 & 72 \\
\hline Taal en cultuur & 2 & 10 & 21 & 8 & 60 \\
\hline Recht en openbare orde & 1 & 8 & 21 & 7 & 63 \\
\hline Natuurwetenschappen & 1 & 6 & 17 & 7 & 70 \\
\hline
\end{tabular}


Tabel A3.6 (vervolg)

Grootte van de organisatie waarin schoolverlaters werkzaam zijn

\begin{tabular}{lrrrrr}
\hline Opleidingssector & 1 pers & $\begin{array}{r}2 \mathrm{t} / \mathrm{m} 9 \\
\text { pers } \\
\%\end{array}$ & $\begin{array}{r}10 \mathrm{t} / \mathrm{m} \text { 49 } \\
\text { pers } \\
\%\end{array}$ & $\begin{array}{r}50 \mathrm{t} / \mathrm{m} \text { 99 } \\
\text { pers } \\
\%\end{array}$ & $\begin{array}{r}\geq 100 \\
\text { pers } \\
\%\end{array}$ \\
\hline Totaal & 1 & 16 & 22 & $\mathbf{9}$ & 52 \\
\hline
\end{tabular}

Toelichting

Het betreft hier de grootte van de totale organisatie (inclusief eventuele andere vestigingen). 
Tabel A3.7

Beloning van werkende schoolverlaters

\begin{tabular}{|c|c|c|}
\hline Opleidingssector & $\begin{array}{r}\text { gemiddeld } \\
\text { bruto maandloon }\end{array}$ & $\begin{array}{l}\text { gemiddeld } \\
\text { bruto uurloon }\end{array}$ \\
\hline
\end{tabular}

HAVO/VWO

HAVO

911

6,33

VWO

$905-6,16$

932

6,16
6,91

VMBO

$640 \quad 4,54$

Theoretische leerweg

592

4,54

Landbouw

4,44

Techniek

617

4,37

Economie

675

4,63

Gezondheidszorg

4,39

BOL niveau 1/2

630

4,67

Landbouw

969

6,77

Techniek

849

6,29

Economie

1.109

7,02

Gezondheidszorg

931
925

6,22
7,77

BOL niveau $3 / 4$

1.218

Landbouw

Techniek

1.114

7,22

Economie

1.461

8,93

Gezondheidszorg

1.194

7,86

Gedrag en maatschappij

8,98

BBL niveau $1 / 2$

1.216

8,83

Landbouw

1.241

8,78

Techniek

1.229

8,04

Economie

1.404

8,74

Gezondheidszorg

\section{7,84}

1.163

10,59

BBL niveau 3/4

1.554

11,36

Landbouw

10,75
10,70

Techniek

1.672

Economie

1.765

1.390

1.569

8,75

Gezondheidszorg

1.402

12,33

Gedrag en maatschappij

12,40

HBO

1.737

11,70

Landbouw

1.763

10,96

Onderwijs

Techniek

1.773

12,24

Economie

1.909

11,57

Gezondheidszorg

1.798

11,31

$\begin{array}{ll}1.619 & 12,88\end{array}$

Gedrag en maatschappij

1.521

11,38

Taal en cultuur

11,42

wo

2.196

14,14

Landbouw

2.196
2.003

Techniek

2.237

2.394

13,61

Economie

Gezondheidszorg

2.508

14,65

Gedrag en maatschappij

2.048

1.776

2.329

Recht en openbare orde

2.017

14,46
12,79

14,43

12,67 
Tabel A3.7 (vervolg)

Beloning van werkende schoolverlaters

Opleidingssector

gemiddeld

bruto maandloon

gemiddeld

bruto uurloon

$€$

Totaal

1.441

9,84

Toelichting

- Dit betreft het bruto inkomen in de hoofdfunctie. Dit is inclusief toeslagen maar exclusief inkomen uit overwerk. Er is hier niet gecorrigeerd voor verschillen in leeftijd van de schoolverlaters. 
Tabel A3.8

Vereist opleidingsniveau voor de huidige functie volgens de werkgever

\begin{tabular}{|c|c|c|c|}
\hline Opleidingssector & $\begin{array}{r}\text { lager } \\
\%\end{array}$ & $\begin{array}{r}\text { zelfde } \\
\%\end{array}$ & $\begin{array}{r}\text { hoger } \\
\%\end{array}$ \\
\hline HAVO/VWO & 42 & 37 & 21 \\
\hline HAVO & 48 & 34 & 18 \\
\hline VWO & 23 & 45 & 32 \\
\hline VMBO & 13 & 52 & 35 \\
\hline Theoretische leerweg & 12 & 56 & 32 \\
\hline Landbouw & 17 & 43 & 41 \\
\hline Techniek & 13 & 53 & 34 \\
\hline Economie & 17 & 47 & 36 \\
\hline Gezondheidszorg & 9 & 53 & 38 \\
\hline BOL niveau 1/2 & 41 & 36 & 23 \\
\hline Landbouw & 65 & 22 & 12 \\
\hline Techniek & 36 & 45 & 19 \\
\hline Economie & 47 & 35 & 18 \\
\hline Gezondheidszorg & 30 & 29 & 41 \\
\hline BOL niveau 3/4 & 28 & 68 & 4 \\
\hline Landbouw & 50 & 48 & 2 \\
\hline Techniek & 28 & 69 & 3 \\
\hline Economie & 30 & 64 & 6 \\
\hline Gezondheidszorg & 22 & 76 & 2 \\
\hline Gedrag en maatschappij & 20 & 75 & 5 \\
\hline BBL niveau 1/2 & 47 & 34 & 19 \\
\hline Landbouw & 54 & 32 & 15 \\
\hline Techniek & 41 & 39 & 20 \\
\hline Economie & 60 & 15 & 25 \\
\hline Gezondheidszorg & 40 & 51 & 9 \\
\hline BBL niveau 3/4 & 27 & 70 & 3 \\
\hline Landbouw & 58 & 41 & 1 \\
\hline Techniek & 57 & 41 & 2 \\
\hline Economie & 39 & 61 & 0 \\
\hline Gezondheidszorg & 15 & 82 & 4 \\
\hline Gedrag en maatschappij & 8 & 90 & 3 \\
\hline HBO & 25 & 74 & 1 \\
\hline Landbouw & 32 & 67 & 1 \\
\hline Onderwijs & 6 & 94 & 0 \\
\hline Techniek & 22 & 77 & 1 \\
\hline Economie & 31 & 68 & 2 \\
\hline Gezondheidszorg & 22 & 78 & 0 \\
\hline Gedrag en maatschappij & 42 & 58 & 0 \\
\hline Taal en cultuur & 27 & 69 & 4 \\
\hline wo & 37 & 58 & 5 \\
\hline Landbouw & 40 & 58 & 2 \\
\hline Techniek & 33 & 66 & 1 \\
\hline Economie & 47 & 51 & 2 \\
\hline Gezondheidszorg & 11 & 73 & 16 \\
\hline Gedrag en maatschappij & 48 & 49 & 3 \\
\hline Taal en cultuur & 55 & 37 & 8 \\
\hline Recht en openbare orde & 24 & 72 & 4 \\
\hline Natuurwetenschappen & 27 & 62 & 11 \\
\hline
\end{tabular}


Tabel A3.8 (vervolg)

Vereist opleidingsniveau voor de huidige functie volgens de werkgever

\begin{tabular}{lccr}
\hline Opleidingssector & $\begin{array}{r}\text { lager } \\
\%\end{array}$ & $\begin{array}{r}\text { zelfde } \\
\%\end{array}$ & $\begin{array}{r}\text { hoger } \\
\%\end{array}$ \\
\hline Totaal & 29 & 60 & 11 \\
\hline
\end{tabular}

Toelichting

Vraag in de enquête:

- Welk opleidingsniveau werd door uw werkgever voor deze functie minimaal vereist? 
Tabel A3.9

Vereiste opleidingsrichting voor de huidige functie volgens de werkgever

\begin{tabular}{|c|c|c|c|}
\hline Opleidingssector & $\begin{array}{r}\text { eigen/verwante } \\
\text { richting } \\
\%\end{array}$ & $\begin{array}{r}\text { andere } \\
\text { richting } \\
\%\end{array}$ & $\begin{array}{r}\text { geen } \\
\text { richting } \\
\%\end{array}$ \\
\hline VMBO & 64 & 2 & 34 \\
\hline Theoretische leerweg & 63 & 3 & 34 \\
\hline Landbouw & 58 & 3 & 39 \\
\hline Techniek & 68 & 0 & 32 \\
\hline Economie & 53 & 6 & 40 \\
\hline Gezondheidszorg & 69 & & 31 \\
\hline BOL niveau $1 / 2$ & 62 & 3 & 35 \\
\hline Landbouw & 48 & 5 & 47 \\
\hline Techniek & 75 & 1 & 23 \\
\hline Economie & 51 & 5 & 44 \\
\hline Gezondheidszorg & 75 & & 25 \\
\hline BOL niveau $3 / 4$ & 69 & 4 & 27 \\
\hline Landbouw & 62 & 3 & 35 \\
\hline Techniek & 72 & 2 & 26 \\
\hline Economie & 54 & 5 & 40 \\
\hline Gezondheidszorg & 82 & 3 & 15 \\
\hline Gedrag en maatschappij & 76 & 4 & 20 \\
\hline BBL niveau $1 / 2$ & 66 & 4 & 30 \\
\hline Landbouw & 49 & 15 & 36 \\
\hline Techniek & 74 & 3 & 23 \\
\hline Economie & 48 & 2 & 50 \\
\hline Gezondheidszorg & 81 & 3 & 16 \\
\hline BBL niveau $3 / 4$ & 82 & 3 & 15 \\
\hline Landbouw & 62 & 19 & 19 \\
\hline Techniek & 82 & & 18 \\
\hline Economie & 60 & 6 & 33 \\
\hline Gezondheidszorg & 88 & 1 & 10 \\
\hline Gedrag en maatschappij & 97 & & 3 \\
\hline HBO & 78 & 4 & 18 \\
\hline Landbouw & 67 & 8 & 25 \\
\hline Onderwijs & 95 & 1 & 4 \\
\hline Techniek & 81 & 3 & 16 \\
\hline Economie & 61 & 6 & 33 \\
\hline Gezondheidszorg & 94 & 2 & 4 \\
\hline Gedrag en maatschappij & 80 & 5 & 14 \\
\hline Taal en cultuur & 70 & 6 & 24 \\
\hline wo & 72 & 4 & 24 \\
\hline Landbouw & 74 & 5 & 21 \\
\hline Techniek & 77 & 3 & 21 \\
\hline Economie & 70 & 2 & 28 \\
\hline Gezondheidszorg & 90 & 1 & 9 \\
\hline Gedrag en maatschappij & 65 & 6 & 28 \\
\hline Taal en cultuur & 55 & 7 & 38 \\
\hline Recht en openbare orde & 77 & 5 & 18 \\
\hline Natuurwetenschappen & 76 & 4 & 21 \\
\hline
\end{tabular}


Tabel A3.9 (vervolg)

Vereiste opleidingsrichting voor de huidige functie volgens de werkgever

\begin{tabular}{lrrr}
\hline Opleidingssector & $\begin{array}{r}\text { eigen/verwante } \\
\text { richting } \\
\%\end{array}$ & $\begin{array}{r}\text { andere } \\
\text { richting } \\
\%\end{array}$ & $\begin{array}{r}\text { geen } \\
\text { richting } \\
\%\end{array}$ \\
\hline Totaal & 72 & 3 & 24 \\
\hline
\end{tabular}

Toelichting

Vraag in de enquête:

- Welke opleidingsrichting werd door uw werkgever voor deze functie vereist? 
Tabel A3.10

Wekelijkse arbeidsduur van werkende schoolverlaters

HAVO/VWO

HAVO

VWO

VMBO

Theoretische leerweg

Landbouw

Techniek

Economie

Gezondheidszorg

BOL niveau 1/2

Landbouw

Techniek

Economie

34,0

Gezondheidszorg

BOL niveau 3/4

Landbouw

Techniek

Economie

35,4

Gezondheidszorg

Gedrag en maatschappij

BBL niveau 1/2

Landbouw

Techniek

35,1

Economie

Gezondheidszorg

BBL niveau 3/4

Landbouw

36,4

Techniek

38,5

Economie

Gezondheidszorg

Gedrag en maatschappij

HBO

Landbouw

Onderwijs

34,6

Techniek

38,7

Economie

Gezondheidszorg

31,4

Gedrag en maatschappij

Taal en cultuur

Wo

Landbouw

Techniek

Economie

Gezondheidszorg

Gedrag en maatschappij

Taal en cultuur

33,8

Recht en openbare orde 
Tabel A3.10 (vervolg)

Wekelijkse arbeidsduur van werkende schoolverlaters

Opleidingssector

wekelijkse

arbeidsduur uren

Totaal

34,4

Toelichting

- De arbeidsduur betreft zowel het aantal uren in de hoofdfunctie als het aantal uren in eventuele nevenfuncties (HBO en WO). 
Tabel A3.11

Oordeel van de werkende schoolverlaters over de aansluiting tussen de afgesloten opleiding en de huidige functie

\begin{tabular}{|c|c|c|c|c|}
\hline Opleidingssector & $\begin{array}{r}\text { goed } \\
\%\end{array}$ & $\begin{array}{r}\text { voldoende } \\
\%\end{array}$ & $\begin{array}{r}\text { matig } \\
\%\end{array}$ & $\begin{array}{r}\text { slecht } \\
\%\end{array}$ \\
\hline BOL niveau $1 / 2$ & 43 & 30 & 15 & 12 \\
\hline Landbouw & 35 & 36 & 2 & 27 \\
\hline Techniek & 42 & 34 & 15 & 10 \\
\hline Economie & 41 & 30 & 17 & 12 \\
\hline Gezondheidszorg & 50 & 26 & 10 & 14 \\
\hline BOL niveau $3 / 4$ & 39 & 41 & 12 & 8 \\
\hline Landbouw & 38 & 41 & 12 & 9 \\
\hline Techniek & 35 & 46 & 10 & 9 \\
\hline Economie & 31 & 44 & 16 & 10 \\
\hline Gezondheidszorg & 52 & 33 & 10 & 5 \\
\hline Gedrag en maatschappij & 40 & 40 & 12 & 8 \\
\hline BBL niveau $1 / 2$ & 60 & 25 & 10 & 5 \\
\hline Landbouw & 56 & 31 & 10 & 4 \\
\hline Techniek & 55 & 28 & 10 & 7 \\
\hline Economie & 53 & 29 & 14 & 4 \\
\hline Gezondheidszorg & 84 & 9 & 5 & 3 \\
\hline BBL niveau $3 / 4$ & 55 & 34 & 10 & 2 \\
\hline Landbouw & 50 & 35 & 9 & 6 \\
\hline Techniek & 55 & 34 & 10 & 1 \\
\hline Economie & 34 & 41 & 22 & 3 \\
\hline Gezondheidszorg & 60 & 33 & 6 & 1 \\
\hline Gedrag en maatschappij & 59 & 27 & 11 & 2 \\
\hline HBO & 34 & 43 & 16 & 8 \\
\hline Landbouw & 26 & 42 & 18 & 14 \\
\hline Onderwijs & 56 & 36 & 5 & 3 \\
\hline Techniek & 28 & 48 & 17 & 7 \\
\hline Economie & 24 & 45 & 21 & 10 \\
\hline Gezondheidszorg & 42 & 42 & 12 & 4 \\
\hline Gedrag en maatschappij & 31 & 41 & 18 & 10 \\
\hline Taal en cultuur & 32 & 35 & 17 & 17 \\
\hline wo & 42 & 35 & 14 & 9 \\
\hline Landbouw & 45 & 34 & 12 & 9 \\
\hline Techniek & 48 & 35 & 11 & 5 \\
\hline Economie & 37 & 42 & 17 & 5 \\
\hline Gezondheidszorg & 63 & 28 & 6 & 4 \\
\hline Gedrag en maatschappij & 31 & 36 & 19 & 14 \\
\hline Taal en cultuur & 29 & 30 & 20 & 21 \\
\hline Recht en openbare orde & 46 & 37 & 11 & 6 \\
\hline Natuurwetenschappen & 48 & 31 & 12 & 10 \\
\hline Totaal & 44 & 36 & 13 & 7 \\
\hline
\end{tabular}

Toelichting

Vraag in de enquête:

- Hoe vindt u de aansluiting tussen uw [...] opleiding en uw huidige functie? 
Tabel A3.12

Percentage werkende schoolverlaters dat op zoek is naar een andere baan

Opleidingssector $\quad \%$

$\begin{array}{lr}\text { HAVO/VWO } & 10\end{array}$

HAVO 10

VWO 10

VMBO

Theoretische leerweg 11

Landbouw $\quad 6$

Techniek 8

Economie $\quad 12$

$\begin{array}{ll}\text { Gezondheidszorg } & 12\end{array}$

BOL niveau $1 / 2 \quad 16$

Landbouw $\quad 25$

\begin{tabular}{ll} 
Techniek & 7 \\
\hline
\end{tabular}

Economie $\quad 17$

$\begin{array}{lr}\text { Gezondheidszorg } & 20\end{array}$

$\begin{array}{ll}\text { BOL niveau 3/4 } & 17\end{array}$

Landbouw 16

$\begin{array}{lr}\text { Techniek } & 16\end{array}$

Economie $\quad 20$

Gezondheidszorg 14

Gedrag en maatschappij 19

BBL niveau 1/2 12

Landbouw 13

$\begin{array}{ll}\text { Techniek } & 12 \\ 12\end{array}$

Economie $\quad 12$

$\begin{array}{ll}\text { Gezondheidszorg } & 10\end{array}$

BBL niveau 3/4

Landbouw 16

$\begin{array}{lr}\text { Techniek } & 8\end{array}$

Economie $\quad 18$

$\begin{array}{lr}\text { Gezondheidszorg } & 12\end{array}$

$\begin{array}{ll}\text { Gedrag en maatschappij } & 27\end{array}$

HBO 23

Landbouw $\quad 24$

$\begin{array}{ll}\text { Onderwijs } & 15\end{array}$

Techniek 19

Economie $\quad 27$

$\begin{array}{ll}\text { Gezondheidszorg } & 21\end{array}$

Gedrag en maatschappij 28

$\begin{array}{ll}\text { Taal en cultuur } & 40\end{array}$

WO $\quad 22$

Landbouw 22

$\begin{array}{ll}\text { Techniek } & 17\end{array}$

$\begin{array}{lr}\text { Economie } & 18\end{array}$

Gezondheidszorg $\quad 17$

Gedrag en maatschappij $\quad 31$

Taal en cultuur $\quad 35$

Recht en openbare orde $\quad 17$

$\begin{array}{ll}\text { Natuurwetenschappen } & 19\end{array}$

$\begin{array}{ll}\text { Totaal } & 17\end{array}$ 
Tabel A4.1

Enkele kernindicatoren

\begin{tabular}{|c|c|c|c|c|c|c|c|c|c|}
\hline Opleidingssector & $\begin{array}{r}\text { opgehoogd } \\
\text { aantal } \\
\text { populatie }\end{array}$ & $\begin{array}{l}\text { verder } \\
\text { leren }\end{array}$ & $\begin{array}{r}\text { zelfde } \\
\text { opleiding } \\
\text { opnieuw } \\
\text { kiezen }\end{array}$ & $\begin{array}{r}\text { werk- } \\
\text { loosheid }\end{array}$ & $\begin{array}{r}\text { intrede } \\
\text { werk- } \\
\text { loosheid }\end{array}$ & $\begin{array}{r}\text { flexibele } \\
\text { aanstelling }\end{array}$ & $\begin{array}{r}\text { bruto } \\
\text { uurloon }\end{array}$ & $\begin{array}{r}\text { minimaal } \\
\text { eigen } \\
\text { niveau }\end{array}$ & $\begin{array}{r}\text { eigen/ } \\
\text { verwante } \\
\text { richting }\end{array}$ \\
\hline & & $\%$ & $\%$ & $\%$ & maanden & $\%$ & $€$ & $\%$ & $\%$ \\
\hline HAVO/VWO & 60.208 & 91 & $\mathbf{x}$ & 17 & 0,6 & 37 & 6,33 & 48 & $\mathbf{x}$ \\
\hline HAVO & 34.226 & 90 & $\mathrm{x}$ & 18 & 0,7 & 38 & 6,16 & 52 & $\mathrm{x}$ \\
\hline VWO & 25.982 & 91 & $x$ & 15 & 0,4 & 34 & 6,91 & 77 & $\mathrm{x}$ \\
\hline VMBO & 79.138 & 88 & $\mathbf{x}$ & 6 & 0,4 & 44 & 4,54 & 87 & 64 \\
\hline Theoretische leerweg & 38.143 & 90 & $\mathrm{x}$ & 12 & 0,5 & 45 & 4,44 & 88 & 63 \\
\hline Landbouw & 6.103 & 84 & $\mathrm{x}$ & 8 & 0,8 & 53 & 4,37 & 84 & 58 \\
\hline Techniek & 14.371 & 84 & $\mathrm{x}$ & 2 & 0,3 & 47 & 4,63 & 87 & 68 \\
\hline Economie & 10.738 & 84 & $\mathrm{x}$ & 9 & 0,2 & 35 & 4,39 & 83 & 53 \\
\hline Gezondheidszorg & 9.783 & 92 & $x$ & 7 & 0,7 & 38 & 4,67 & 91 & 69 \\
\hline BOL niveau $1 / 2$ & 15.528 & 46 & 61 & 25 & 2,2 & 47 & 6,77 & 59 & 62 \\
\hline Landbouw & 287 & 39 & 59 & 21 & 2,3 & 47 & 6,29 & 34 & 48 \\
\hline Techniek & 3.167 & 55 & 62 & 23 & 2,1 & 50 & 7,02 & 64 & 75 \\
\hline Economie & 8.557 & 41 & 58 & 28 & 2,4 & 46 & 6,22 & 53 & 51 \\
\hline Gezondheidszorg & 3.517 & 49 & 68 & 19 & 1,9 & 47 & 7,77 & 70 & 75 \\
\hline BOL niveau $3 / 4$ & 46.343 & 51 & 76 & 11 & 1,2 & 39 & 8,47 & 72 & 69 \\
\hline Landbouw & 3.460 & 47 & 74 & 9 & 1,0 & 42 & 7,22 & 50 & 62 \\
\hline Techniek & 10.391 & 56 & 80 & 9 & 1,5 & 37 & 8,93 & 72 & 72 \\
\hline Economie & 14.845 & 55 & 70 & 12 & 1,5 & 45 & 7,86 & 70 & 54 \\
\hline Gezondheidszorg & 7.396 & 36 & 80 & 6 & 0,7 & 31 & 8,98 & 78 & 82 \\
\hline Gedrag en maatschappij & 10.251 & 51 & 81 & 16 & 1,1 & 41 & 8,83 & 80 & 76 \\
\hline
\end{tabular}


Tabel A4. 1 (vervolg)

Enkele kernindicatoren

\begin{tabular}{|c|c|c|c|c|c|c|c|c|c|}
\hline \multirow[t]{2}{*}{ Opleidingssector } & \multirow[t]{2}{*}{$\begin{array}{r}\text { opgehoogd } \\
\text { aantal } \\
\text { populatie }\end{array}$} & \multirow{2}{*}{$\begin{array}{r}\text { verder } \\
\text { leren } \\
\\
\%\end{array}$} & \multirow{2}{*}{$\begin{array}{r}\text { zelfde } \\
\text { opleiding } \\
\text { opnieuw } \\
\text { kiezen } \\
\%\end{array}$} & \multirow{2}{*}{$\begin{array}{r}\text { werk- } \\
\text { loosheid } \\
\%\end{array}$} & \multirow{2}{*}{$\begin{array}{r}\text { intrede } \\
\text { werk- } \\
\text { loosheid } \\
\text { maanden }\end{array}$} & \multirow{2}{*}{$\begin{array}{r}\text { flexibele } \\
\text { aanstelling } \\
\%\end{array}$} & \multirow{2}{*}{$\begin{array}{r}\text { bruto } \\
\text { uurloon } \\
\\
€\end{array}$} & \multirow{2}{*}{$\begin{array}{r}\text { minimaal } \\
\text { eigen } \\
\text { niveau } \\
\%\end{array}$} & \multirow{2}{*}{$\begin{array}{r}\text { eigen/ } \\
\text { verwante } \\
\text { richting } \\
\%\end{array}$} \\
\hline & & & & & & & & & \\
\hline BBL niveau $1 / 2$ & 20.651 & 25 & 70 & 7 & 0,7 & 33 & 8,78 & 53 & 66 \\
\hline Landbouw & 2.067 & 29 & 67 & 3 & 0,3 & 17 & 8,04 & 47 & 49 \\
\hline Techniek & 8.592 & 29 & 72 & 5 & 0,5 & 45 & 8,74 & 59 & 74 \\
\hline Economie & 5.843 & 25 & 57 & 10 & 0,9 & 34 & 7,84 & 40 & 48 \\
\hline Gezondheidszorg & 4.148 & 17 & 86 & 8 & 1,0 & 11 & 10,59 & 60 & 81 \\
\hline BBL niveau $3 / 4$ & 19.240 & 16 & 80 & 4 & 0,4 & 12 & 11,36 & 73 & 82 \\
\hline Landbouw & 1.028 & 21 & 79 & 2 & 0,3 & 18 & 10,75 & 42 & 62 \\
\hline Techniek & 3.112 & 17 & 83 & 1 & 0,2 & 14 & 10,70 & 43 & 82 \\
\hline Economie & 3.661 & 31 & 64 & 9 & 0,8 & 40 & 8,75 & 61 & 60 \\
\hline Gezondheidszorg & 8.609 & 8 & 84 & 4 & 0,0 & 3 & 12,33 & 86 & 88 \\
\hline Gedrag en maatschappij & 2.830 & 17 & 82 & 4 & 1,5 & 7 & 12,40 & 93 & 97 \\
\hline HBO & 46.990 & 32 & 78 & 6 & 1,2 & 41 & 11,70 & 75 & 78 \\
\hline Landbouw & 1.834 & 30 & 75 & 8 & 1,8 & 48 & 10,96 & 68 & 67 \\
\hline Onderwijs & 7.603 & 27 & 88 & 4 & 0,8 & 30 & 12,24 & 94 & 95 \\
\hline Techniek & 9.607 & 35 & 79 & 6 & 1,4 & 46 & 11,57 & 78 & 81 \\
\hline Economie & 15.552 & 39 & 70 & 7 & 1,2 & 47 & 11,31 & 70 & 61 \\
\hline Gezondheidszorg & 4.610 & 26 & 84 & 5 & 0,9 & 31 & 12,88 & 78 & 94 \\
\hline Gedrag en maatschappij & 5.834 & 25 & 76 & 6 & 1,5 & 45 & 11,38 & 58 & 80 \\
\hline Taal en cultuur & 1.949 & 28 & 85 & 13 & 1,9 & 48 & 11,42 & 73 & 70 \\
\hline wo & 21.273 & 31 & 81 & 5 & 1,8 & 52 & 14,14 & 63 & 72 \\
\hline Landbouw & 811 & 30 & 77 & 6 & 2,2 & 67 & 12,94 & 60 & 74 \\
\hline Techniek & 3.285 & 23 & 82 & 4 & 2,2 & 50 & 13,61 & 67 & 77 \\
\hline Economie & 3.495 & 27 & 83 & 4 & 1,5 & 37 & 14,65 & 53 & 70 \\
\hline
\end{tabular}


Tabel A4.1 (vervolg)

Enkele kernindicatoren

\begin{tabular}{|c|c|c|c|c|c|c|c|c|c|}
\hline \multirow[t]{2}{*}{ Opleidingssector } & \multirow[t]{2}{*}{$\begin{array}{r}\text { opgehoogd } \\
\text { aantal } \\
\text { populatie }\end{array}$} & $\begin{array}{c}\text { verder } \\
\text { leren }\end{array}$ & $\begin{array}{r}\text { zelfde } \\
\text { opleiding } \\
\text { opnieuw } \\
\text { kiezen }\end{array}$ & \multirow[t]{2}{*}{$\begin{array}{r}\text { werk- } \\
\text { loosheid } \\
\%\end{array}$} & \multirow{2}{*}{$\begin{array}{r}\text { intrede } \\
\text { werk- } \\
\text { loosheid } \\
\text { maanden }\end{array}$} & \multirow{2}{*}{$\begin{array}{r}\text { flexibele } \\
\text { aanstelling } \\
\%\end{array}$} & \multirow{2}{*}{$\begin{array}{r}\text { bruto } \\
\text { uurloon } \\
€\end{array}$} & \multirow{2}{*}{$\begin{array}{r}\text { minimaal } \\
\text { eigen } \\
\text { niveau } \\
\%\end{array}$} & \multirow{2}{*}{$\begin{array}{r}\text { eigen/ } \\
\text { verwante } \\
\text { richting } \\
\%\end{array}$} \\
\hline & & $\%$ & $\%$ & & & & & & \\
\hline \multicolumn{10}{|l|}{ WO (vervolg) } \\
\hline Gezondheidszorg & 2.720 & 47 & 89 & 3 & 1,0 & 65 & 15,66 & 89 & 90 \\
\hline Gedrag en maatschappij & 4.561 & 24 & 76 & 7 & 2,0 & 52 & 14,46 & 52 & 65 \\
\hline Taal en cultuur & 2.310 & 37 & 73 & 10 & 2,2 & 58 & 12,79 & 45 & 55 \\
\hline Recht en openbare orde & 2.351 & 30 & 88 & 4 & 1,6 & 48 & 14,43 & 76 & 77 \\
\hline Natuurwetenschappen & 1.740 & 48 & 79 & 5 & 1,6 & 68 & 12,67 & 73 & 76 \\
\hline Totaal & 309.372 & 60 & 76 & 8 & 1,0 & 38 & 9,84 & 71 & 72 \\
\hline
\end{tabular}

Toelichting

- Deze tabel geeft een samenvattend beeld. Zie ook de tabellen C.2, A2.1, A1.4, A3.1, A3.3, A3.7, A3.8 en A3.9. 
B. Tabellen per opleidingsrichting 



\section{Inhoud}

\section{Bestemming van schoolverlaters}

B1.1 De uitstroom van schoolverlaters verbijzonderd naar geslacht, etniciteit en gemiddelde leeftijd op moment van enquête

B1.2 Vooropleiding van schoolverlaters

B1.3 Bestemming van schoolverlaters

B1.4 Gevolgde opleiding opnieuw kiezen?

\section{Doorstroom naar vervolgonderwijs}

B2.1 Doorstroom van schoolverlaters naar vervolgonderwijs

B2.2 Belangrijkste opleidingen van schoolverlaters die een vervolgopleiding zijn gaan volgen

B2.3 Oordeel van schoolverlaters over de aansluiting van de afgesloten opleiding met de vervolgopleiding

B2.4 Doorstroom van schoolverlaters naar kenniscentrum beroepsonderwijs bedrijfsleven

\section{Intrede op de arbeidsmarkt}

B3.1 Werkloosheid en gemiddelde intredewerkloosheid van schoolverlaters die zich aanbieden op de arbeidsmarkt

B3.2 Aard van het dienstverband van werkende schoolverlaters

B3.3 Percentage werkende schoolverlaters met een flexibele aanstelling

B3.4 Belangrijkste bedrijfsgroepen waarin schoolverlaters werkzaam zijn

B3.5 Belangrijkste beroepsgroepen waarin schoolverlaters werkzaam zijn

B3.6 Grootte van de organisatie waarin schoolverlaters werkzaam zijn

B3.7 Beloning van werkende schoolverlaters

B3.8 Vereist opleidingsniveau voor de huidige functie volgens de werkgever

B3.9 Vereiste opleidingsrichting voor de huidige functie volgens de werkgever

B3.10 Wekelijkse arbeidsduur van werkende schoolverlaters

B3.11 Oordeel van de werkende schoolverlaters over de aansluiting tussen de afgesloten opleiding en de huidige functie

B3.12 Percentage werkende schoolverlaters dat op zoek is naar een andere baan

\section{Kernindicatoren}

\section{B4.1 Enkele kernindicatoren}


Tabel B1.1

De uitstroom van schoolverlaters verbijzonderd naar geslacht, etniciteit en gemiddelde leeftijd op moment van enquête

\begin{tabular}{lrrr}
\hline Opleidingsrichting & vrouw & allochtoon & leeftijd \\
& $\%$ & gem
\end{tabular}

VMBO

Theoretische leerweg

Landbouw Gem Iw landbouw en nat.omgeving

Landbouw KB landbouw en nat.omgeving

Landbouw BB landbouw en nat.omgeving

Techniek KB bouwtechniek

Techniek KB voertuigentechniek

Techniek KB electrotechniek

Techniek KB overig

Techniek BB bouwtechniek

Techniek BB metaaltechniek

Techniek BB voertuigentechniek

Techniek BB electrotechniek

Techniek BB overig

Economie KB

Economie KB administratie

Economie KB handel en administratie

Economie BB administratie

Economie BB handel en verkoop

Economie BB handel en administratie

Economie BB consumptief

Zorg en Welzijn Gem Iw zorg en welzijn-breed

Zorg en Welzijn KB

Zorg en Welzijn KB verzorging

Zorg en Welzijn KB zorg en welzijn-breed

Zorg en Welzijn BB verzorging

Zorg en Welzijn BB zorg en welzijn-breed

$\begin{array}{rrr}50 & 11 & 17,4 \\ 59 & 0 & 17,4 \\ 56 & 3 & 17,5 \\ 49 & 4 & 17,7 \\ 0 & 0 & 17,5 \\ 0 & 0 & 17,6 \\ 2 & 0 & 17,6 \\ 50 & 17 & 17,3 \\ 2 & 4 & 17,5 \\ 0 & 0 & 17,7 \\ 0 & 3 & 17,5 \\ 7 & 0 & 17,7 \\ 50 & 0 & 17,4 \\ 37 & 12 & 17,2 \\ 51 & 11 & 17,7 \\ 61 & 16 & 17,5 \\ 52 & 31 & 17,4 \\ 41 & 26 & 17,4 \\ 74 & 53 & 17,7 \\ 30 & 6 & 17,7 \\ 93 & 0 & 17,2 \\ 50 & 14 & 17,3 \\ 100 & 10 & 17,4 \\ 93 & 5 & 17,3 \\ 98 & 4 & 17,6 \\ 100 & 20 & 17,4\end{array}$

BOL niveau $1 / 2$

$A B$ Beveiliging

AB Secretarieel

BB Bloemschikken

BB Dierverzorging en veterinaire ondersteuning

BB Motorvoertuigen

BB Informatietechniek

BB Scheepvaart

BB Bedrijfsadministratie

BB Beveiliging

BB Secretarieel

BB Detailhandel/ambulante handel

BB Horeca, instellingskeuken en contractcatering

BB Toerisme, recreatie en reizen

$B B$ Verpleging en verzorging

gem.

BOL niveau $3 / 4$

ZB Plantenteelt

ZB Veehouderij

ZB Bloemschikken

ZB Dierverzorging en veterinaire ondersteuning

ZB Paardenhouderij en paardensport

ZB Groene ruimte

ZB Graf. techn, communicatie, audiovisueel en multimedia

ZB Scheepvaart

ZB Automatisering

ZB Bedrijfsadministratief

ZB Toerisme, recreatie en reizen

$Z B$ Verpleging en verzorging

ZB Uiterlijke verzorging

$\begin{array}{rrr}25 & 10 & 18,8 \\ 72 & 71 & 23,6 \\ 100 & 6 & 19,7 \\ 85 & 0 & 19,9 \\ 0 & 23 & 20,2 \\ 2 & 36 & 22,2 \\ 4 & 0 & 33,2 \\ 58 & 49 & 21,5 \\ 32 & 10 & 19,4 \\ 100 & 43 & 21,7 \\ 46 & 21 & 20,0 \\ 41 & 10 & 19,9 \\ 72 & 11 & 20,6 \\ 93 & 12 & 21,4\end{array}$


Tabel B1.1 (vervolg)

De uitstroom van schoolverlaters verbijzonderd naar geslacht, etniciteit en gemiddelde leeftijd op moment van enquête

\begin{tabular}{|c|c|c|c|}
\hline Opleidingsrichting & $\begin{array}{r}\text { vrouw } \\
\%\end{array}$ & $\begin{array}{r}\text { allochtoon } \\
\%\end{array}$ & $\begin{array}{r}\text { leeftijd } \\
\text { gem. }\end{array}$ \\
\hline
\end{tabular}

BOL niveau 3/4 (vervolg)

ZB Sociaal pedagogisch werk

KF Plantenteelt

KF Veehouderij

$\mathrm{KF}$ voedingsmiddelentechnologie

KF Bloemschikken

$\mathrm{KF}$ Dierverzorging en veterinaire ondersteuning

KF Paardenhouderij en paardensport

KF Groene ruimte

KF Milieutoezicht

MKF Techniek

MKF Bouw

MKF Grond-, water- en wegenbouw

MKF Beschermings- en afwerkingstechnieken

MKF Reclame, presentatie en communicatie

MKF Operationele techniek

MKF Werktuigbouwkunde

MKF Motorvoertuigen

MKF Motorvoertuigen en carrosserietechniek

MKF Energie- en informatietechniek

MKF Energietechniek

MKF Informatietechniek

MKF Edelsmeden

MKF Graf. techn, communicatie, audiovisueel en multimedia

MKF Laboratoriumtechniek

MKF Haven en vervoer

MKF Scheepvaart

MKF Transport en logistiek

MKF Automatisering

MKF Bedrijfsadministratief

MKF Commerciee

MKF Economisch-juridisch

MKF Secretarieel

MKF Detailhandel/ambulante handel

MKF Groothandel/distributie

MKF Horeca, instellingskeuken en contractcatering

MKF Toerisme, recreatie en reizen

MKF Assistenten gezondheidszorg

MKF Facilitaire dienstverlening

MKF Sport en bewegen

MKF Verpleging en verzorging

MKF Sociaal-cultureel werker

MKF Sociaal-pedagogisch werk algemeen

MKF Sociaal-juridisch werk

Specialist Informatietechniek

Specialist Automatisering

$\begin{array}{rrr}97 & 6 & 21,6 \\ 12 & 4 & 21,3 \\ 24 & 1 & 21,4 \\ 53 & 3 & 21,9 \\ 92 & 0 & 21,5 \\ 92 & 3 & 21,5 \\ 90 & 0 & 21,6 \\ 12 & 1 & 21,9 \\ 29 & 0 & 21,8 \\ 6 & 13 & 22,3 \\ 8 & 6 & 21,8 \\ 1 & 4 & 22,2 \\ 66 & 4 & 22,4 \\ 79 & 2 & 22,2 \\ 0 & 5 & 22,0 \\ 1 & 7 & 21,8 \\ 2 & 7 & 21,8 \\ 47 & 3 & 22,2 \\ 0 & 12 & 21,9 \\ 0 & 7 & 21,7 \\ 1 & 12 & 21,9 \\ 72 & 5 & 24,2 \\ 43 & 7 & 23,1 \\ 49 & 8 & 22,6 \\ 0 & 0 & 21,2 \\ 8 & 0 & 26,8 \\ 11 & 14 & 21,4 \\ 3 & 19 & 21,6 \\ 45 & 16 & 21,6 \\ 52 & 14 & 21,4 \\ 54 & 5 & 21,0 \\ 98 & 17 & 21,0 \\ 40 & 20 & 21,1 \\ 17 & 9 & 21,5 \\ 53 & 8 & 22,0 \\ 89 & 7 & 21,8 \\ 99 & 15 & 21,4 \\ 58 & 7 & 21,2 \\ 44 & 5 & 21,9 \\ 89 & 7 & 22,3 \\ 65 & 9 & 22,0 \\ 93 & 6 & 21,5 \\ 82 & 47 & 22,2 \\ 44 & 3 & 21,6 \\ 3 & 6 & 21,7 \\ & & \end{array}$

$B B L$ niveau $1 / 2$

AB Groene ruimte

$A B$ Horeca, instellingskeuken en contractcatering

$A B$ Verpleging en verzorging

BB Plantenteelt

BB Bloemschikken

BB Dierverzorging en veterinaire ondersteuning

BB Groene ruimte

BB Bouw

BB Motorvoertuigen

BB Installatie-, service- en onderhoudstechniek

$\begin{array}{rrr}36 & 5 & 38,1 \\ 67 & 20 & 29,9 \\ 100 & 2 & 40,7 \\ 10 & 7 & 23,6 \\ 89 & 2 & 22,3 \\ 76 & 0 & 20,4 \\ 3 & 5 & 29,3 \\ 0 & 4 & 21,4 \\ 0 & 7 & 22,2 \\ 0 & 5 & 21,7\end{array}$


Tabel B1.1 (vervolg)

De uitstroom van schoolverlaters verbijzonderd naar geslacht, etniciteit en gemiddelde leeftijd op moment van enquête

Opleidingsrichting

$\begin{array}{rrr}\text { vrouw } & \text { allochtoon } & \text { leeftijd } \\ \% & \% & \text { gem. }\end{array}$

BBL niveau 1/2 (vervolg)

BB Wegvervoer

BB Detailhandel/ambulante handel

BB Horeca, instellingskeuken en contractcatering

BB Facilitaire dienstverlening

BB Verpleging en verzorging

BBL niveau $3 / 4$

ZB Plantenteelt

ZB Bloemschikken

ZB Groene ruimte

ZB Bouw

ZB Motorvoertuigen

ZB Horeca, instellingskeuken en contractcatering

ZB Verpleging en verzorging

ZB Sociaal-pedagogisch werk

KF Groene ruimte

MKF Detailhandel/ambulante handel

MKF Horeca, instellingskeuken en contractcatering

MKF Verpleging en verzorging

MKF Sociaal-pedagogisch werk

$\begin{array}{rrr}1 & 0 & 20,8 \\ 61 & 11 & 20,2 \\ 35 & 2 & 21,3 \\ 100 & 17 & 39,6 \\ 94 & 18 & 38,6\end{array}$

Zie ook toelichting bladzijde 5 
Tabel B1.2

Vooropleiding van schoolverlaters

\begin{tabular}{lrrrr}
\hline Opleidingsrichting & MAVO & HAVO & VWO & VBO \\
$\%$ & & $\begin{array}{r}\text { BOL } \\
\%\end{array}$ & $\begin{array}{r}\text { BBL } \\
\%\end{array}$ & $\begin{array}{r}\text { overig } \\
\%\end{array}$
\end{tabular}

BOL niveau $1 / 2$

$\mathrm{AB}$ Beveiliging

AB Secretarieel

BB Bloemschikken

BB Dierverzorging en veterinaire ondersteuning

BB Motorvoertuigen

BB Informatietech

BB Scheepvaart

BB Bedrijfsadm

BB Secretarieel

BB Detailhandel/ambulante handel

BB Horeca, instellingskeuken en contractcatering

BB Toerisme, recreatie en reizen

BB Verpleging en verzorging

$\begin{array}{rr}43 & \\ 5 & 14 \\ 12 & \\ 6 & \\ 25 & \\ 25 & \\ 24 & \\ 22 & \\ 54 & \\ 21 & \\ 21 & \\ 33 & \\ 47 & \\ 20 & \end{array}$

$\begin{array}{rr}0 & \\ 14 & \\ 0 & \\ 0 & 6 \\ 0 & \\ 0 & \\ 6 & 2 \\ 0 & 6 \\ 2 & \\ 3 & 0 \\ 0 & \\ 1 & \\ 0 & \\ 0 & \end{array}$

\section{BOL niveau $3 / 4$}

ZB Plantenteelt

ZB Veehouderij

ZB Bloemschikken

ZB Dierverzorging en veterinaire ondersteuning

ZB Paardenhouderij en paardensport

ZB Groene ruimte

ZB Graf. techn, communicatie, audiovisueel en multimedia

ZB Scheepvaart

ZB Automatisering

ZB Bedrijfsadministratief

ZB Toerisme, recreatie en reizen

$Z B$ Verpleging en verzorging

ZB Uiterlijke verzorging

ZB Sociaal pedagogisch werk

KF Plantenteelt

48
14
53
69
66
65
41
62
38
66
64
54
41
66

$\begin{array}{rrr}4 & 0 & 6 \\ 29 & 10 & 24 \\ 6 & 0 & 24 \\ 10 & 0 & 12 \\ 0 & 3 & 6 \\ 4 & 2 & 2 \\ 0 & 12 & 12 \\ 8 & 0 & 8 \\ 4 & 0 & 3 \\ 6 & 0 & 3 \\ 10 & 0 & 5 \\ 2 & 3 & 6 \\ 12 & 0 & 0 \\ 2 & 0 & 11\end{array}$

$\begin{array}{rrrr}72 & 0 & 1 & 1 \\ 75 & 3 & 0 & 4 \\ 66 & 4 & 5 & 5 \\ 62 & 0 & 0 & 2 \\ 47 & 0 & 0 & 10 \\ 63 & 0 & 0 & 0 \\ 45 & 9 & 9 & 0 \\ 61 & 10 & 0 & 5 \\ 40 & 7 & 0 & 7 \\ 18 & 9 & 0 & 0 \\ 14 & 1 & 0 & 2 \\ 49 & 2 & 1 & 2 \\ 32 & 4 & 0 & 1 \\ 41 & 4 & 1 & 3 \\ 22 & 5 & 0 & 1\end{array}$


Tabel B1.2 (vervolg)

Vooropleiding van schoolverlaters

\begin{tabular}{lrrrr}
\hline Opleidingsrichting & MAVO & HAVO & VWO & VBO \\
$\%$ & & $\begin{array}{r}\text { BOL } \\
\%\end{array}$ & $\begin{array}{r}\text { BBL } \\
\%\end{array}$ & $\begin{array}{r}\text { overig } \\
\%\end{array}$
\end{tabular}

BOL niveau 3/4 (vervolg)

KF Veehouderij

$\mathrm{KF}$ voedingsmiddelentechnologie

KF Bloemschikken

KF Dierverzorging en veterinaire ondersteuning

KF Paardenhouderij en paardensport

KF Groene ruimte

KF Milieutoezicht

MKF Techniek

MKF Bouw

MKF Grond-, water- en wegenbouw

MKF Beschermings- en afwerkingstechnieken

MKF Reclame, presentatie en communicatie

MKF Operationele techniek

MKF Werktuigbouwkunde

MKF Motorvoertuigen

MKF Motorvoertuigen en carrosserietechniek

MKF Energie- en informatietechniek

MKF Energietechniek

MKF Informatietechniek

MKF Edelsmeden

MKF Graf, techn, communicatie, audiovisueel en multimedia

MKF Laboratoriumtechniek

MKF Haven en vervoe

MKF Scheepvaart

MKF Transport en logistiek

MKF Automatisering

MKF Bedrijfsadministratie

MKF Commercieel

MKF Economisch-juridisch

MKF Secretarieel

MKF Detailhandelambulante hande

$\begin{array}{rr}67 & 2 \\ 71 & 10 \\ 48 & 4 \\ 53 & 26 \\ 58 & 27 \\ 65 & 10 \\ 90 & 4 \\ 84 & 0 \\ 63 & 9 \\ 62 & 22 \\ 82 & 9 \\ 69 & 24 \\ 81 & 2 \\ 68 & 7 \\ 52 & 13 \\ 50 & 24 \\ 58 & 10 \\ 62 & 0 \\ 63 & 9 \\ 33 & 37 \\ 41 & 41 \\ 72 & 15 \\ 80 & 13 \\ 51 & 12 \\ 71 & 4 \\ 69 & 5 \\ 70 & 13 \\ 78 & 12 \\ 74 & 10 \\ 71 & 14 \\ 77 & 5 \\ & \end{array}$

$\begin{array}{rr}2 & 0 \\ 10 & 0 \\ 4 & 0 \\ 26 & 3 \\ 27 & 5 \\ 10 & 0 \\ 4 & 0 \\ 0 & 0 \\ 9 & 2 \\ 22 & 0 \\ 9 & 0 \\ 24 & 2 \\ 2 & 0 \\ 7 & 0 \\ 13 & 0 \\ 24 & 0 \\ 10 & 0 \\ 0 & 0 \\ 9 & 1 \\ 37 & 16 \\ 41 & 0 \\ 15 & 0 \\ 13 & 0 \\ 12 & 0 \\ 4 & 0 \\ 5 & 0 \\ 13 & 1 \\ 12 & 1 \\ 10 & 0 \\ 14 & 0 \\ 5 & 0 \\ & \end{array}$

$\begin{array}{rlll}25 & 1 & 0 & 4 \\ 19 & 0 & 0 & 0 \\ 44 & 0 & 0 & 4 \\ 13 & 2 & 0 & 3 \\ 9 & 0 & 0 & 1 \\ 22 & 0 & 0 & 4 \\ 5 & 0 & 0 & 0 \\ 11 & 0 & 0 & 5 \\ 24 & 1 & 0 & 1 \\ 14 & 2 & 0 & 0 \\ 4 & 0 & 0 & 4 \\ 3 & 2 & 0 & 0 \\ 14 & 0 & 0 & 2 \\ 22 & 1 & 0 & 2 \\ 33 & 0 & 0 & 2 \\ 26 & 0 & 0 & 0 \\ 30 & 0 & 0 & 2 \\ 27 & 0 & 0 & 11 \\ 25 & 1 & 0 & 1 \\ 9 & 0 & 0 & 5 \\ 13 & 3 & 2 & 0 \\ 4 & 7 & 0 & 2 \\ 7 & 0 & 0 & 0 \\ 26 & 9 & 0 & 3 \\ 21 & 2 & 0 & 2 \\ 23 & 1 & 0 & 1 \\ 14 & 1 & 0 & 0 \\ 7 & 3 & 0 & 1 \\ 11 & 3 & 0 & 2 \\ 13 & 1 & 0 & 1 \\ 17 & 0 & 0 & 1 \\ & 0 & 0 & \end{array}$


Tabel B1.2 (vervolg)

Vooropleiding van schoolverlaters

\begin{tabular}{lrrrrr}
\hline Opleidingsrichting & MAVO & HAVO & VWO & VBO \\
$\%$ & & $\begin{array}{r}\text { BOL } \\
\%\end{array}$ & $\begin{array}{r}\text { BBL } \\
\%\end{array}$ & $\begin{array}{r}\text { overig } \\
\%\end{array}$
\end{tabular}

BOL niveau 3/4 (vervolg)

MKF Horea, instellingskeuken en contractcatering

MKF Toerisme, recreatie en reizen

MKF Assistenten gezondheidszorg

MKF Facilitaire dienstverlening

MKF Sport en bewegen

MKF Verpleging en verzorging

MKF Sociaal-cultureel werker

MKF Sociaal-pedagogisch werk algemeen

MKF Sociaal-juridisch werk

Specialist Informatietechniek

Specialist Automatisering

$\begin{array}{lr}91 & \\ 69 & 23 \\ 70 & 23 \\ 75 & \\ 73 & \\ 74 & 15 \\ 73 & \\ 74 & \\ 73 & \\ 65 & \\ 88 & \\ 65 & \end{array}$

\section{BBL niveau $1 / 2$}

$A B$ Horeca, instellingskeuken en contractcatering

的 verzorging

BB Plantenteelt

BB Bloemschikken

$B B$ Dierverzorging en veterinaire ondersteuning

BB Groene ruimte

BB Bouw

BB Motorvoertuigen

BB Installatie-, service- en onderhoudstechniek

BB Wegvervoer

BB Detailhandel/ambulante handel

BB Horeca, instellingskeuken en contractcatering

BB Facilitaire dienstverlening

BB Verpleging en verzorging

$\begin{array}{rl}3 & 0 \\ 23 & 0 \\ 23 & 0 \\ 8 & 1 \\ 9 & 0 \\ 15 & 1 \\ 7 & 0 \\ 0 & 0 \\ 3 & 0 \\ 0 & 0 \\ 3 & 0 \\ 15 & 0\end{array}$

0
0
0
1
0
1
0
0
0
0
0
0

6
6
4
12
15
7
17
22
19
28
9
14

0
1
1
0
3
1
3
0
2
2
0
6

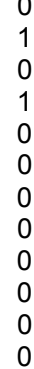

10
31
39
23
31
29
14
15
21
41
23
18
38
24
17

1
7
0
3
1
0
5
0
0
0
0
0
3
0
8

31
47
31
43
45
37
54
62
36
50
60
71
35
44
33

$\begin{array}{rr}6 & 23 \\ 6 & 0 \\ 0 & 0 \\ 4 & 15 \\ 7 & 6 \\ 0 & 13 \\ 5 & 6 \\ 0 & 19 \\ 0 & 29 \\ 0 & 9 \\ 0 & 0 \\ 0 & 6 \\ 2 & 17 \\ 4 & 4 \\ 0 & 21\end{array}$

28
5
17
11
8
21
14
4
14
0
10
6
3
20
18 
Tabel B1.2 (vervolg)

Vooropleiding van schoolverlaters

\begin{tabular}{|c|c|c|c|c|c|c|c|}
\hline Opleidingsrichting & $\begin{array}{r}\text { MAVO } \\
\%\end{array}$ & $\begin{array}{r}\text { HAVO } \\
\%\end{array}$ & $\begin{array}{r}\text { VWO } \\
\%\end{array}$ & $\begin{array}{r}\text { VBO } \\
\%\end{array}$ & $\begin{array}{r}\mathrm{BOL} \\
\%\end{array}$ & $\begin{array}{r}\text { BBL } \\
\%\end{array}$ & $\begin{array}{r}\text { overig } \\
\%\end{array}$ \\
\hline \multicolumn{8}{|l|}{ BBL niveau 3/4 } \\
\hline ZB Plantenteelt & 27 & 5 & 0 & 49 & 0 & 7 & 12 \\
\hline ZB Bloemschikken & 18 & 5 & 3 & 50 & 3 & 17 & 3 \\
\hline ZB Groene ruimte & 23 & 15 & 1 & 39 & 3 & 9 & 11 \\
\hline ZB Bouw & 24 & 0 & 0 & 63 & 0 & 12 & 0 \\
\hline ZB Motorvoertuigen & 27 & 9 & 0 & 55 & 9 & 0 & 0 \\
\hline ZB Horeca, instellingskeuken en contractcatering & 30 & 8 & 3 & 38 & 1 & 17 & 3 \\
\hline ZB Verpleging en verzorging & 29 & 3 & 4 & 29 & 14 & 13 & 8 \\
\hline ZB Sociaal-pedagogisch werk & 43 & 10 & 4 & 25 & 1 & 7 & 10 \\
\hline KF Groene ruimte & 14 & 4 & 10 & 47 & 9 & 17 & 0 \\
\hline MKF Detailhandel/ambulante handel & 52 & 14 & 0 & 24 & 0 & 10 & 0 \\
\hline MKF Horeca, instellingskeuken en contractcatering & 58 & 5 & 0 & 25 & 3 & 9 & 0 \\
\hline MKF Verpleging en verzorging & 51 & 13 & 0 & 14 & 2 & 12 & 8 \\
\hline MKF Sociaal-pedagogisch werk & 54 & 9 & 2 & 21 & 5 & 2 & 7 \\
\hline
\end{tabular}


Tabel B1.3

Bestemming van schoolverlaters

\begin{tabular}{|c|c|c|c|c|c|}
\hline Opleidingsrichting & $\begin{array}{r}\text { studie } \\
\%\end{array}$ & $\begin{array}{r}\text { BBL } \\
\%\end{array}$ & $\begin{array}{r}\text { betaald } \\
\text { werk } \\
\%\end{array}$ & $\begin{array}{r}\text { werk- } \\
\text { loos } \\
\%\end{array}$ & $\begin{array}{r}\text { anders } \\
\%\end{array}$ \\
\hline \multicolumn{6}{|l|}{ VмBо } \\
\hline Theoretische leerweg & 87 & 5 & 5 & 1 & 2 \\
\hline Landbouw Gem Iw landbouw en nat.omgeving & 80 & 9 & 9 & 2 & 0 \\
\hline Landbouw KB landbouw en nat.omgeving & 76 & 12 & 7 & 1 & 3 \\
\hline Landbouw BB landbouw en nat.omgeving & 48 & 26 & 18 & 5 & 3 \\
\hline Techniek KB bouwtechniek & 51 & 39 & 11 & 0 & 0 \\
\hline Techniek KB voertuigentechniek & 21 & 50 & 21 & 4 & 4 \\
\hline Techniek KB electrotechniek & 57 & 25 & 15 & 0 & 2 \\
\hline Techniek KB overig & 77 & 19 & 4 & 0 & 0 \\
\hline Techniek BB bouwtechniek & 22 & 35 & 41 & 0 & 2 \\
\hline Techniek BB metaaltechniek & 15 & 33 & 44 & 0 & 7 \\
\hline Techniek BB voertuigentechniek & 7 & 66 & 28 & 0 & 0 \\
\hline Techniek BB electrotechniek & 37 & 29 & 28 & 0 & 6 \\
\hline Techniek BB overig & 8 & 81 & 5 & 3 & 3 \\
\hline Economie KB & 66 & 24 & 9 & 0 & 0 \\
\hline Economie KB administratie & 77 & 12 & 7 & 0 & 5 \\
\hline Economie KB handel en administratie & 61 & 16 & 16 & 4 & 2 \\
\hline Economie BB administratie & 72 & 7 & 17 & 3 & 0 \\
\hline Economie BB handel en verkoop & 46 & 22 & 25 & 0 & 7 \\
\hline Economie BB handel en administratie & 77 & 14 & 6 & 0 & 3 \\
\hline Economie BB consumptief & 37 & 25 & 29 & 9 & 0 \\
\hline
\end{tabular}

BOL niveau $1 / 2$

AB Beveiliging

$A B$ Secretarieel

BB Bloemschikken

BB Dierverzorging en veterinaire ondersteuning

BB Motorvoertuigen

BB Informatietechniek

BB Scheepvaart

BB Bedrijfsadministratie

BB Beveiliging

BB Secretarieel

BB Detailhandel/ambulante handel

BB Horeca, instellingskeuken en contractcatering

$B B$ Toerisme, recreatie en reizen

BB Verpleging en verzorging

BOL niveau 3/4

ZB Plantenteelt

ZB Veehouderij

ZB Bloemschikken

$Z B$ Dierverzorging en veterinaire ondersteuning

ZB Paardenhouderij en paardensport

ZB Groene ruimte

ZB Graf. techn, communicatie, audiovisueel en multimedia

ZB Scheepvaart

ZB Automatisering

ZB Bedrijfsadministratief

ZB Toerisme, recreatie en reizen

$Z B$ Verpleging en verzorging

ZB Uiterlijke verzorging

ZB Sociaal pedagogisch werk

KF Plantenteelt

KF Veehouderij

$\mathrm{KF}$ voedingsmiddelentechnologie

KF Bloemschikken

KF Dierverzorging en veterinaire ondersteuning

$\begin{array}{rrrrr}26 & 9 & 52 & 8 & 5 \\ 36 & 3 & 23 & 30 & 7 \\ 18 & 17 & 47 & 18 & 0 \\ 26 & 11 & 30 & 9 & 23 \\ 8 & 36 & 39 & 17 & 0 \\ 49 & 4 & 14 & 15 & 17 \\ 16 & 0 & 84 & 0 & 0 \\ 40 & 9 & 35 & 10 & 6 \\ 29 & 7 & 51 & 8 & 6 \\ 41 & 2 & 41 & 16 & 0 \\ 41 & 17 & 24 & 8 & 11 \\ 18 & 47 & 27 & 4 & 4 \\ 22 & 6 & 50 & 17 & 6 \\ 45 & 16 & 24 & 6 & 9\end{array}$

$\begin{array}{rrrrr}27 & 13 & 54 & 1 & 6 \\ 18 & 6 & 63 & 0 & 14 \\ 14 & 17 & 60 & 4 & 4 \\ 29 & 4 & 47 & 14 & 6 \\ 14 & 5 & 62 & 9 & 9 \\ 26 & 2 & 60 & 10 & 3 \\ 20 & 0 & 57 & 20 & 3 \\ 7 & 0 & 90 & 0 & 4 \\ 29 & 0 & 41 & 29 & 0 \\ 15 & 9 & 70 & 0 & 6 \\ 12 & 2 & 78 & 8 & 1 \\ 15 & 13 & 69 & 0 & 3 \\ 22 & 1 & 66 & 2 & 7 \\ 38 & 1 & 51 & 5 & 5 \\ 50 & 0 & 49 & 0 & 1 \\ 52 & 0 & 44 & 1 & 3 \\ 79 & 0 & 21 & 0 & 0 \\ 43 & 6 & 45 & 6 & 0 \\ 47 & 6 & 41 & 2 & 4\end{array}$


Tabel B1.3 (vervolg)

Bestemming van schoolverlaters

\begin{tabular}{|c|c|c|c|c|c|}
\hline Opleidingsrichting & $\begin{array}{r}\text { studie } \\
\quad \%\end{array}$ & $\begin{array}{r}\text { BBL } \\
\%\end{array}$ & $\begin{array}{r}\text { betaald } \\
\text { werk } \\
\%\end{array}$ & $\begin{array}{r}\text { werk- } \\
\text { loos } \\
\%\end{array}$ & $\begin{array}{r}\text { anders } \\
\%\end{array}$ \\
\hline \multicolumn{6}{|l|}{ BOL niveau 3/4 (vervolg) } \\
\hline KF Paardenhouderij en paardensport & 35 & 13 & 47 & 0 & 4 \\
\hline KF Groene ruimte & 39 & 4 & 52 & 1 & 5 \\
\hline KF Milieutoezicht & 45 & 11 & 31 & 8 & 5 \\
\hline MKF Techniek & 61 & 6 & 33 & 0 & 0 \\
\hline MKF Bouw & 63 & 5 & 30 & 1 & 2 \\
\hline MKF Grond-, water- en wegenbouw & 55 & 0 & 40 & 5 & 0 \\
\hline MKF Beschermings- en afwerkingstechnieken & 26 & 0 & 65 & 4 & 4 \\
\hline MKF Reclame, presentatie en communicatie & 56 & 0 & 39 & 0 & 5 \\
\hline MKF Operationele techniek & 9 & 0 & 78 & 8 & 5 \\
\hline MKF Werktuigbouwkunde & 58 & 1 & 37 & 3 & 2 \\
\hline MKF Motorvoertuigen & 43 & 7 & 45 & 5 & 0 \\
\hline MKF Motorvoertuigen en carrosserietechniek & 21 & 7 & 72 & 0 & 0 \\
\hline MKF Energie- en informatietechniek & 60 & 0 & 40 & 0 & 0 \\
\hline MKF Energietechniek & 44 & 4 & 44 & 0 & 8 \\
\hline MKF Informatietechniek & 66 & 4 & 26 & 3 & 2 \\
\hline MKF Edelsmeden & 25 & 1 & 57 & 5 & 13 \\
\hline MKF Graf. techn, communicatie, audiovisueel en multimedia & 48 & 2 & 41 & 7 & 2 \\
\hline MKF Laboratoriumtechniek & 52 & 5 & 33 & 9 & 0 \\
\hline MKF Haven en vervoer & 13 & 0 & 75 & 0 & 13 \\
\hline MKF Scheepvaart & 29 & 2 & 65 & 2 & 2 \\
\hline MKF Transport en logistiek & 38 & 0 & 58 & 2 & 2 \\
\hline MKF Automatisering & 56 & 0 & 39 & 5 & 1 \\
\hline MKF Bedrijfsadministratief & 59 & 8 & 29 & 3 & 2 \\
\hline MKF Commercieel & 62 & 4 & 28 & 3 & 2 \\
\hline MKF Economisch-juridisch & 76 & 0 & 9 & 7 & 7 \\
\hline MKF Secretarieel & 45 & 1 & 44 & 5 & 6 \\
\hline MKF Detailhandel/ambulante handel & 57 & 5 & 31 & 4 & 3 \\
\hline MKF Groothandel/distributie & 62 & 0 & 32 & 0 & 6 \\
\hline MKF Horeca, instellingskeuken en contractcatering & 43 & 5 & 46 & 2 & 4 \\
\hline MKF Toerisme, recreatie en reizen & 51 & 1 & 42 & 5 & 2 \\
\hline MKF Assistenten gezondheidszorg & 31 & 3 & 62 & 2 & 3 \\
\hline MKF Facilitaire dienstverlening & 58 & 5 & 25 & 7 & 5 \\
\hline MKF Sport en bewegen & 57 & 4 & 36 & 1 & 2 \\
\hline MKF Verpleging en verzorging & 22 & 10 & 66 & 1 & 1 \\
\hline MKF Sociaal-cultureel werker & 48 & 4 & 31 & 13 & 4 \\
\hline MKF Sociaal-pedagogisch werk algemeen & 49 & 7 & 39 & 1 & 4 \\
\hline MKF Sociaal-juridisch werk & 70 & 2 & 22 & 2 & 4 \\
\hline Specialist Informatietechniek & 89 & 3 & 9 & 0 & 0 \\
\hline Specialist Automatisering & 51 & 0 & 43 & 0 & 5 \\
\hline \multicolumn{6}{|l|}{ BBL niveau $1 / 2$} \\
\hline AB Groene ruimte & 2 & 9 & 78 & 1 & 9 \\
\hline AB Horeca, instellingskeuken en contractcatering & 5 & 12 & 71 & 12 & 0 \\
\hline$A B$ Verpleging en verzorging & 0 & 2 & 91 & 0 & 7 \\
\hline BB Plantenteelt & 0 & 11 & 74 & 3 & 12 \\
\hline BB Bloemschikken & 4 & 30 & 58 & 3 & 5 \\
\hline BB Dierverzorging en veterinaire ondersteuning & 6 & 7 & 84 & 0 & 4 \\
\hline BB Groene ruimte & 0 & 29 & 67 & 2 & 2 \\
\hline BB Bouw & 0 & 21 & 68 & 7 & 4 \\
\hline BB Motorvoertuigen & 7 & 13 & 67 & 0 & 13 \\
\hline BB Installatie-, service- en onderhoudstechniek & 9 & 45 & 41 & 5 & 0 \\
\hline BB Wegvervoer & 0 & 0 & 96 & 0 & 4 \\
\hline BB Detailhandel/ambulante handel & 17 & 17 & 67 & 0 & 0 \\
\hline BB Horeca, instellingskeuken en contractcatering & 0 & 45 & 46 & 4 & 5 \\
\hline BB Facilitaire dienstverlening & 0 & 0 & 97 & 0 & 3 \\
\hline BB Verpleging en verzorging & 0 & 20 & 71 & 9 & 1 \\
\hline
\end{tabular}


Tabel B1.3 (vervolg)

Bestemming van schoolverlaters

\begin{tabular}{lrrrrr}
\hline Opleidingsrichting & studie & BBL betaald & $\begin{array}{r}\text { werk- } \\
\text { werk } \\
\text { loos } \\
\%\end{array}$ & $\%$ & $\%$ \\
\hline
\end{tabular}

BBL niveau $3 / 4$

ZB Plantenteelt

ZB Bloemschikken

ZB Groene ruimte

ZB Bouw

ZB Motorvoertuigen

ZB Horeca, instellingskeuken en contractcatering

ZB Verpleging en verzorging

ZB Sociaal-pedagogisch werk

KF Groene ruimte

MKF Detailhandel/ambulante handel

MKF Horeca, instellingskeuken en contractcatering

MKF Verpleging en verzorging

MKF Sociaal-pedagogisch werk

$\begin{array}{rrrrr}0 & 4 & 83 & 0 & 13 \\ 0 & 3 & 86 & 1 & 10 \\ 3 & 12 & 79 & 3 & 4 \\ 0 & 0 & 100 & 0 & 0 \\ 0 & 9 & 82 & 0 & 9 \\ 9 & 7 & 84 & 0 & 0 \\ 1 & 5 & 89 & 2 & 3 \\ 10 & 0 & 83 & 3 & 3 \\ 9 & 9 & 83 & 0 & 0 \\ 32 & 5 & 46 & 14 & 5 \\ 19 & 3 & 69 & 3 & 7 \\ 2 & 4 & 92 & 0 & 3 \\ 7 & 7 & 80 & 0 & 7\end{array}$


Tabel B1.4

Gevolgde opleiding opnieuw kiezen?

\begin{tabular}{lrrr}
\hline Opleidingsrichting & $\begin{array}{r}\text { zelfde } \\
\text { opleiding }\end{array}$ & $\begin{array}{r}\text { andere } \\
\text { opleiding }\end{array}$ & $\begin{array}{r}\text { geen } \\
\text { opleiding } \\
\%\end{array}$ \\
& $\%$ & $\%$
\end{tabular}

BOL niveau $1 / 2$

$A B$ Beveiliging

AB Secretarieel

BB Bloemschikken

BB Dierverzorging en veterinaire ondersteuning

BB Motorvoertuigen

BB Informatietechniek

BB Scheepvaart

BB Bedrijfsadministratie

BB Beveiliging

BB Secretarieel

BB Detailhandel/ambulante handel

BB Horeca, instellingskeuken en contractcatering

BB Toerisme, recreatie en reizen

BB Verpleging en verzorging

$\begin{array}{rrr}60 & 28 & 12 \\ 54 & 39 & 7 \\ 59 & 24 & 18 \\ 63 & 28 & 9 \\ 61 & 37 & 3 \\ 49 & 48 & 4 \\ 93 & 0 & 7 \\ 57 & 39 & 4 \\ 51 & 43 & 6 \\ 50 & 44 & 6 \\ 51 & 43 & 6 \\ 75 & 21 & 4 \\ 56 & 39 & 6 \\ 75 & 22 & 3\end{array}$

BOL niveau $3 / 4$

ZB Plantenteelt

ZB Veehouderij

ZB Bloemschikken

$Z B$ Dierverzorging en veterinaire ondersteuning

ZB Paardenhouderij en paardensport

ZB Groene ruimte

ZB Graf. techn, communicatie, audiovisueel en multimedia

ZB Scheepvaart

ZB Automatisering

ZB Bedrijfsadministratief

ZB Toerisme, recreatie en reizen

$Z B$ Verpleging en verzorging

ZB Uiterlijke verzorging

ZB Sociaal pedagogisch werk

KF Plantenteelt

KF Veehouderij

$\mathrm{KF}$ voedingsmiddelentechnologie

KF Bloemschikken

KF Dierverzorging en veterinaire ondersteuning

KF Paardenhouderij en paardensport

KF Groene ruimte

KF Milieutoezicht

MKF Techniek

MKF Bouw

MKF Grond-, water- en wegenbouw

MKF Beschermings- en afwerkingstechnieken

MKF Reclame, presentatie en communicatie

MKF Operationele techniek

MKF Werktuigbouwkunde

MKF Motorvoertuigen

MKF Motorvoertuigen en carrosserietechniek

MKF Energie- en informatietechniek

MKF Energietechniek

MKF Informatietechniek

MKF Edelsmeden

MKF Graf. techn, communicatie, audiovisueel en multimedia

MKF Laboratoriumtechniek

MKF Haven en vervoer

MKF Scheepvaart

MKF Transport en logistiek

MKF Automatisering

\begin{tabular}{|c|c|c|}
\hline 66 & 27 & 6 \\
\hline 74 & 11 & 16 \\
\hline 74 & 26 & 0 \\
\hline 59 & 38 & 4 \\
\hline 44 & 47 & 9 \\
\hline 73 & 24 & 3 \\
\hline 40 & 60 & 0 \\
\hline 77 & 23 & 0 \\
\hline 76 & 24 & 0 \\
\hline 67 & 33 & 0 \\
\hline 66 & 32 & 3 \\
\hline 84 & 13 & 2 \\
\hline 67 & 31 & 2 \\
\hline 84 & 15 & 1 \\
\hline 80 & 18 & 1 \\
\hline 80 & 19 & 1 \\
\hline 74 & 26 & 0 \\
\hline 77 & 23 & 0 \\
\hline 83 & 17 & 0 \\
\hline 83 & 17 & 0 \\
\hline 73 & 25 & 2 \\
\hline 82 & 18 & 0 \\
\hline 88 & 13 & 0 \\
\hline 85 & 15 & 1 \\
\hline 89 & 11 & 0 \\
\hline 60 & 40 & 0 \\
\hline 79 & 21 & 0 \\
\hline 93 & 7 & 0 \\
\hline 87 & 13 & 0 \\
\hline 63 & 37 & 0 \\
\hline 66 & 34 & 0 \\
\hline 88 & 10 & 2 \\
\hline 78 & 19 & 4 \\
\hline 76 & 22 & 1 \\
\hline 78 & 22 & 0 \\
\hline 55 & 43 & 2 \\
\hline 88 & 12 & 0 \\
\hline 81 & 19 & 0 \\
\hline 87 & 13 & 0 \\
\hline 70 & 25 & 5 \\
\hline 55 & 40 & 5 \\
\hline
\end{tabular}


Tabel B1.4 (vervolg)

Gevolgde opleiding opnieuw kiezen?

Opleidingsrichting

$\begin{array}{rrr}\text { zelfde } & \text { andere } & \text { geen andere } \\ \text { opleiding } & \text { opleiding } & \text { opleiding } \\ \% & \% & \%\end{array}$

BOL niveau 3/4 (vervolg)

MKF Bedrijfsadministratief

MKF Commercieel

MKF Economisch-juridisch

MKF Secretarieel

MKF Detailhandel/ambulante handel

MKF Groothandel/distributie

MKF Horeca, instellingskeuken en contractcatering

MKF Toerisme, recreatie en reizen

MKF Assistenten gezondheidszorg

MKF Facilitaire dienstverlening

MKF Sport en bewegen

MKF Verpleging en verzorging

MKF Sociaal-cultureel werker

MKF Sociaal-pedagogisch werk algemeen

MKF Sociaal-juridisch werk

Specialist Informatietechniek

Specialist Automatisering

83

72

69

68

57

80

78

73

84

69

88

81

59

84

BBL niveau $1 / 2$

AB Groene ruimte

$A B$ Horeca, instellingskeuken en contractcatering

$A B$ Verpleging en verzorging

BB Plantenteelt

BB Bloemschikken

BB Dierverzorging en veterinaire ondersteuning

BB Groene ruimte

BB Bouw

BB Motorvoertuigen

BB Installatie-, service- en onderhoudstechniek

BB Wegvervoer

BB Detailhandel/ambulante handel

BB Horeca, instellingskeuken en contractcatering

BB Facilitaire dienstverlening

$B B$ Verpleging en verzorging

$\begin{array}{rrr}61 & 13 & 27 \\ 55 & 17 & 28 \\ 78 & 9 & 13 \\ 51 & 26 & 23 \\ 77 & 22 & 1 \\ 41 & 42 & 17 \\ 75 & 15 & 9 \\ 64 & 29 & 7 \\ 60 & 27 & 13 \\ 73 & 18 & 9 \\ 84 & 12 & 4 \\ 39 & 39 & 22 \\ 72 & 22 & 6 \\ 87 & 7 & 7 \\ 86 & 9 & 5\end{array}$

BBL niveau $3 / 4$

ZB Plantenteelt

ZB Bloemschikken

ZB Groene ruimte

ZB Bouw

ZB Motorvoertuigen

ZB Horeca, instellingskeuken en contractcatering

ZB Verpleging en verzorging

ZB Sociaal-pedagogisch werk

KF Groene ruimte

MKF Detailhandel/ambulante handel

MKF Horeca, instellingskeuken en contractcatering

MKF Verpleging en verzorging

MKF Sociaal-pedagogisch werk

17

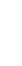


Tabel B2.1

Doorstroom van schoolverlaters naar vervolgonderwijs

\begin{tabular}{|c|c|c|c|c|c|c|c|c|c|}
\hline Opleidingsrichting & $\begin{array}{r}\text { verder } \\
\text { leren } \\
\%\end{array}$ & $\begin{array}{r}\text { MAVO } \\
\%\end{array}$ & $\begin{array}{r}\text { HAVO } \\
\%\end{array}$ & $\begin{array}{r}\text { VMBO } \\
\%\end{array}$ & $\begin{array}{r}\mathrm{BOL} \\
\text { niv. } 1 / 2 \\
\%\end{array}$ & $\begin{array}{r}\text { BOL } \\
\text { niv. } 3 / 4 \\
\%\end{array}$ & $\begin{array}{r}\text { BBL } \\
\text { niv. } 1 / 2 \\
\%\end{array}$ & $\begin{array}{r}\text { BBL } \\
\text { niv. } 3 / 4 \\
\%\end{array}$ & $\begin{array}{r}\mathrm{HBO} \\
\%\end{array}$ \\
\hline
\end{tabular}

Theoretische leerweg

Landbouw Gem Iw landbouw en nat.omgeving

Landbouw KB landbouw en nat.omgeving

Landbouw BB landbouw en nat.omgeving

Techniek KB bouwtechniek

Techniek KB voertuigentechniek

Techniek KB electrotechniek

Techniek BB bouwtechniek

Techniek BB metaaltechniek

Techniek BB voertuigentechniek

Techniek BB overig

Economie KB

Economie KB administratie

Economie KB handel en administratie

Economie BB administratie

Economie BB handel en administratie

Economie BB consumptief

Zorg en Welzijn Gem Iw zorg en welzijn-breed

Zorg en Welzijn KB

Zorg en Welzijn KB verzorging

Zorg en Welzijn KB zorg en welzijn-breed

Zorg en Welzijn BB verzorging

Zorg en Welzijn BB zorg en welzijn-breed

$\begin{array}{rl} & \\ 19 & 5 \\ 91 & 0 \\ 88 & 0 \\ 78 & 0 \\ 95 & 0 \\ 87 & 0 \\ 90 & 0 \\ 90 & 0 \\ 68 & 0 \\ 77 & 0 \\ 72 & 0 \\ 95 & 0 \\ 91 & 0 \\ 92 & 0 \\ 82 & 0 \\ 76 & 0 \\ 91 & 0 \\ 73 & 0 \\ 100 & 0 \\ 100 & 0 \\ 88 & 0 \\ 97 & 0 \\ 87 & 0 \\ 92 & 0\end{array}$

\section{BOL niveau $1 / 2$}

BB Motorvoertuigen

BB Informatietechniek

BB Beveiliging

BB Detailhandel/ambulante handel

$\begin{array}{rrrrrrrrr}86 & 0 & 0 & 0 & 0 & 20 & 0 & 63 & 17 \\ 47 & 0 & 0 & 0 & 12 & 54 & 10 & 13 & 12 \\ 21 & 11 & 0 & 0 & 23 & 43 & 12 & 5 & 5 \\ 61 & 0 & 0 & 0 & 9 & 53 & 7 & 31 & 0\end{array}$


Tabel B2.1 (vervolg)

Doorstroom van schoolverlaters naar vervolgonderwijs

\begin{tabular}{|c|c|c|c|c|c|c|c|c|}
\hline Opleidingsrichting & $\begin{array}{r}\text { verder } \\
\text { leren } \\
\%\end{array}$ & $\begin{array}{r}\text { MAVO } \\
\%\end{array}$ & $\begin{array}{r}\text { HAVO } \\
\%\end{array}$ & $\begin{array}{r}\text { VMBO } \\
\%\end{array}$ & $\begin{array}{r}\text { BOL } \\
\text { niv. } 1 / 2 \\
\%\end{array}$ & $\begin{array}{r}\text { BOL } \\
\text { niv. } 3 / 4 \\
\%\end{array}$ & $\begin{array}{r}\text { BBL } \\
\text { niv. } 1 / 2 \\
\%\end{array}$ & $\begin{array}{r}\text { BBL } \\
\text { niv. } 3 / 4 \\
\%\end{array}$ \\
\hline
\end{tabular}

BOL niveau $1 / 2$ (vervolg)

(B) en contractcatering

BB Verpleging en verzorging

BOL niveau $3 / 4$

ZB Plantenteelt

ZB Bloemschikken

ZB Dierverzorging en veterinaire ondersteuning

ZB Groene ruimte

ZB Toerisme, recreatie en reizen

ZB Verpleging en verzorging

ZB Uiterlijke verzorging

ZB Sociaal pedagogisch werk

KF Plantenteelt

KF Veehouderij

KF voedingsmiddelen

KF Blocmschikken

KF Dierverzorging

KF Groene ruimte

MKF Bouw

MKF Bouw

MKF Grond-, water- en wegenbouw

MKF Reclame, presentatie en communicatie

MKF Werktuigbouwkunde

MKF Motorvoertuigen

MKF Energie- en informatietechniek

MKF Informatietechniek

MKF Graf. techn, communicatie, audiovisueel en multimedia

MKF Laboratoriumtechniek

MKF Transport en logistiek

MKF Automatisering

72
51

47
42
23
40
15
32
22
39
55
60
79
45
48
42
58
64
56
50
59
52
66
68
54
61
30
63

0
0

0
0
0
0
0
0
0
0
0
0
0
0
0
0
0
0
0
0
0
0
0
0
0
0
0
0

0
0
0
0
0
0
0
0
0
0
0
0
0
1
0
0
0
0
0
0
0
0
0
0
0
0

0
0
0
0
0
0
0
0
0
0
0
0
0
0
0
0
0
0
0
0
0
0
0
0
0
0
0

1

0
0
6
10
6
2
0
1
0
0
0
0
0
0
0
1
0
0
0
0
0
0
0
0
0
0

\section{59}

9
0

62
27

$\begin{array}{rrrr}91 & 0 & 4 & 5 \\ 42 & 0 & 51 & 7 \\ 83 & 0 & 11 & 0 \\ 51 & 0 & 22 & 16 \\ 25 & 0 & 11 & 58 \\ 46 & 0 & 50 & 2 \\ 69 & 0 & 8 & 23 \\ 16 & 0 & 7 & 76 \\ 10 & 0 & 4 & 86 \\ 4 & 0 & 2 & 94 \\ 0 & 0 & 5 & 95 \\ 4 & 0 & 13 & 83 \\ 8 & 2 & 2 & 88 \\ 6 & 0 & 0 & 93 \\ 0 & 0 & 0 & 100 \\ 0 & 1 & 1 & 97 \\ 0 & 0 & 3 & 97 \\ 0 & 0 & 0 & 100 \\ 3 & 0 & 0 & 97 \\ 9 & 0 & 9 & 81 \\ 0 & 0 & 0 & 100 \\ 0 & 0 & 0 & 100 \\ 8 & 0 & 9 & 83 \\ 2 & 0 & 2 & 96 \\ 6 & 0 & 2 & 92 \\ 2 & 0 & 0 & 98\end{array}$


Tabel B2.1 (vervolg)

Doorstroom van schoolverlaters naar vervolgonderwijs

\begin{tabular}{|c|c|c|c|c|c|c|c|c|c|}
\hline Opleidingsrichting & $\begin{array}{r}\text { verder } \\
\text { leren } \\
\%\end{array}$ & $\begin{array}{r}\text { MAVO } \\
\%\end{array}$ & $\begin{array}{r}\text { HAVO } \\
\%\end{array}$ & $\begin{array}{r}\text { VBO } \\
\%\end{array}$ & $\begin{array}{r}\text { BOL } \\
\text { niv. } 1 / 2 \\
\%\end{array}$ & $\begin{array}{r}\text { BOL } \\
\text { niv. } 3 / 4 \\
\%\end{array}$ & $\begin{array}{r}\text { BBL } \\
\text { niv. } 1 / 2 \\
\%\end{array}$ & $\begin{array}{r}\text { BBL } \\
\text { niv. } 3 / 4 \\
\%\end{array}$ & $\begin{array}{r}\mathrm{HBO} \\
\%\end{array}$ \\
\hline
\end{tabular}

BOL niveau 3/4 (vervolg)

MKF Bedrijfsadministratief

MKF Commercieel

MKF Economisch-juridisch

MKF Secretarieel

MKF Detailhandel/ambulante hande

MKF Groothandel/distributie

MKF Horeca, instellingskeuken en contractcatering

MKF Toerisme, recreatie en reizen

MKF Assistenten gezondheidszorg

MKF Facilitaire dienstverlening

MKF Sport en bewegen

MKF Verpleging en verzorging

MKF Sociaal-pedagogisch werk algemeen

MKF Sociaal-juridisch werk

Specialist Informatie

Specialist Automatisering

BBL niveau $1 / 2$

$A B$ Groene ruimte

AB Groene ruimte

BB Bloemschikken

BB Groene ruimte

BB Verpleging en verzorging

66
66
74
47
53
69
46
49
33
64
60
33
57
71
83
55

$\begin{array}{lll}0 & 0 & 0 \\ 0 & 0 & \\ 0 & 0 & \\ 0 & 1 & \\ 0 & 0 & \\ 0 & 0 & \\ 0 & 0 \\ 0 & 0 \\ 0 & 0 \\ 0 & 0 \\ 0 & 0 \\ 0 & 0 \\ 0 & 0 \\ 0 & 0 \\ 0 & 0 \\ 0 & 0\end{array}$

$\begin{array}{lll}0 & 0 & 0 \\ 0 & 0 & 2 \\ 0 & 0 & 3 \\ 0 & 0 & 9 \\ 0 & 1 & 4 \\ 0 & 0 & 4 \\ 0 & 0 & 4 \\ 0 & 0 & 4 \\ 0 & 0 & 6 \\ 0 & 0 & 4 \\ 0 & 0 & 2 \\ 0 & 0 & 0 \\ 0 & 1 & 2 \\ 0 & 0 & 6 \\ 0 & 0 & 0 \\ 0 & 0 & 17\end{array}$

$\begin{array}{rrrr}0 & 1 & 1 & 98 \\ 2 & 0 & 1 & 98 \\ 3 & 0 & 0 & 97 \\ 9 & 0 & 0 & 90 \\ 4 & 0 & 3 & 92 \\ 4 & 0 & 0 & 96 \\ 4 & 2 & 2 & 91 \\ 4 & 0 & 0 & 96 \\ 6 & 0 & 4 & 90 \\ 4 & 4 & 4 & 89 \\ 2 & 0 & 0 & 98 \\ 0 & 0 & 2 & 98 \\ 2 & 1 & 3 & 93 \\ 6 & 0 & 0 & 94 \\ 0 & 0 & 0 & 100 \\ 17 & 0 & 0 & 83 \\ & & & \end{array}$

BBL niveau $3 / 4$

ZB Groene ruimte

ZB Horeca, instellingskeuken en contractcatering

\begin{tabular}{rrrrrrrrr}
22 & 0 & 0 & 0 & 0 & 16 & 84 & 0 & 0 \\
36 & 0 & 0 & 0 & 0 & 0 & 0 & 100 & 0 \\
39 & 0 & 0 & 0 & 0 & 2 & 7 & 90 & 0 \\
44 & 0 & 0 & 0 & 0 & 4 & 0 & 92 & 4 \\
21 & 0 & 0 & 0 & 0 & 0 & 8 & 92 & 0 \\
& & & & & & & & \\
27 & 0 & 0 & 0 & 0 & 5 & 11 & 48 & 36 \\
36 & 0 & 0 & 0 & 0 & 13 & 0 & 75 & 12 \\
\hline
\end{tabular}


Tabel B2.2

Belangrijkste opleidingen van schoolverlaters die een vervolgopleiding zijn gaan volgen

VMBO Landbouw Gem Iw landbouw en nat.omgeving

BOL ZB Sociaal-pedagogisch werk

VMBO Landbouw KB landbouw en nat.omgeving

BOL ZB Sociaal-pedagogisch werk

VMBO Landbouw BB landbouw en nat.omgeving

BOL BB Groene ruimte

BOL BB Helpende welzijn

VMBO Techniek KB bouwtechniek

BOL MKF Bouwkunde

BOL MKF Meubelmaken

BBL BB Meubelmaker/interieurbouwer/scheepsinterieurbouwer

BOL MKF Houtbewerking en woninginrichting

BBL BB Primaire timmerkracht

BOL BB Meubelmaken

VMBO Techniek KB voertuigentechniek

BOL MKF Motorvoertuigen

BBL BB Bedrijfsautotechnicus

BBL ZB Stuurman/schipper

VMBO Techniek KB electrotechniek

BOL MKF Energie- en informatietechniek

BBL BB Energie- en informatietechniek

BOL MKF Energietechniek

BBL ZB Energie- en informatietechniek

VMBO Techniek BB bouwtechniek

BBL BB Bouw

BOL BB Meubelmaken

BBL BB Primaire timmerkracht

BBL BB Schilder

VMBO Techniek BB metaaltechniek

BOL BB Informatietechniek

BOL AB Assistent-constructiewerken/lasser

BOL AB Assistent autotechnicus

BOL AB Beveiliging

BOL MKF Beheerder technische infrastructuur

BBL BB Landbouw

BBL BB Techniek

BBL BB Primaire timmerkracht

BBL BB Constructiebankwerker/lasser

BBL BB Monteur montage/onderhoud

BBL BB Autotechnicus

BBL BB Installatie-, service- en onderhoudstechniek

BBL BB Scheepvaart

BBL ZB Logistiek

VMBO Techniek BB voertuigentechniek

BBL BB Motorvoertuigen

BBL BB Autotechnicus

BBL BB Bedrijfsautotechnicus

BBL BB Chauffeur goederenvervoer

VMBO Techniek BB electrotechniek

BBL BB Energie- en informatietechniek 
Tabel B2.2 (vervolg)

Belangrijkste opleidingen van schoolverlaters die een vervolgopleiding zijn gaan volgen

VMBO Techniek BB electrotechniek (vervolg)

BBL BB Monteur sterkstroominstallaties

BOL BB Vliegtuigonderhoudsmonteur

BOL BB Beveiliging

BOL Specialist Informatietechniek

BBL BB Monteur elektrische bedrijfsinstallaties

BBL BB Detailhandel/ambulante handel

BBL ZB Stuurman/schipper

BOL MKF Maritiem officier (zeevaart)

VMBO Economie KB

BOL MKF Commercieel

BOL BB Servicemedewerker ICT

BBL BB Chauffeur goederenvervoer

BOL BB Secretarieel

BOL MKF Directie-secretaresse/management-assistent

BBL BB Kapper

BOL MKF Bouwkunde

14

10

10

10

VMBO Economie KB administratie

BOL BB Informatietechniek

BOL BB Beveiliging

VMBO Economie KB handel en administratie

BOL ZB Boekhoudkundig medewerker

VMBO Economie BB administratie

BOL BB Bedrijfsadministratie

BOL BB Secretariee

BOL BB Servicemedewerker ICT

BOL ZB Secretaresse

VMBO Economie BB handel en administratie

BOL BB Bedrijfsadministratie

BOL BB Secretarieel

BOL BB Assistent-secretaresse

BOL ZB Commercieel medewerker binnendienst

BBL BB Bedrijfsadministratief medewerker

BBL BB Chauffeur goederenvervoer

VMBO Economie BB consumptief

BBL BB Banketbakker

BOL BB Kok

BBL BB Kok

BOL BB Banketbakker

BBL BB Brood- en banketbakker

BBL BB Gastheer/-vrouw

VMBO Zorg en Welzijn Gem Iw zorg en welzijn-breed

BOL MKF Verpleegkundige

BOL ZB Verzorgende

BOL ZB All-round kapper

BOL MKF Administratief-juridisch medewerker - openbaar bestuur

BOL MKF Sociaal-pedagogisch werk

BOL MKF Onderwijsassistent 
Tabel B2.2 (vervolg)

Belangrijkste opleidingen van schoolverlaters die een vervolgopleiding zijn gaan volgen

VMBO Zorg en Welzijn KB

BOL MKF Sociaal-pedagogisch werker

BOL ZB Verzorgende

BOL MKF Onderwijsassistent

VMBO Zorg en Welzijn KB verzorging

BOL ZB Sociaal-pedagogisch werk

BOL ZB Verzorgende

BOL MKF Sociaal-pedagogisch werk

BOL MKF Onderwijsassistent

BBL ZB Verpleging en verzorging

BBL ZB Verzorgende bij inst. voor gezinsverz.

VMBO Zorg en Welzijn KB zorg en welzijn-breed

BOL ZB Sociaal-pedagogisch werk

BOL MKF Sociaal-pedagogisch werk

BOL ZB All-round kapper

BOL ZB Verzorgende

BOL MKF Onderwijsassistent

VMBO Zorg en Welzijn BB verzorging

BOL BB Helpende welzijn

VMBO Zorg en Welzijn BB zorg en welzijn-breed

BOL BB Helpende welzijn

BOL BB Verpleging en verzorging

BBL BB Helpende welzijn

BBL BB Kapper

BOL ZB Sociaal-pedagogisch werk

BOL BB Motorvoertuigen

BBL ZB Eerste autotechnicus

BOL MKF Bouw

HBO Autotechniek

BOL BB Informatietechniek

BOL MKF Informatietechniek

BOL BB Informatietechniek

BOL ZB Medewerker beheer informatiesystemen

$\mathrm{HBO}$ Leraar basisonderwijs

BOL ZB Informatietechniek

\section{BOL BB Beveiliging}

BOL ZB Audiovisueel medewerker

BOL MKF Maritiem officier (zeevaart)

MBO Politie

HAVO

HAVO Studiehuis

BOL AB Algemeen beveiligingsmedewerker

BOL BB Informatietechniek

BOL BB Installatie-, service- en onderhoudstechnie

BOL BB Beveiliging

$B O L$ ZB Verzorgende

BOL ZB Sociaal dienstverlener

BOL KF Milieutoezicht

BOL MKF Administratief-juridisch medewerker - openbaar bestuur

BOL MKF Directie-secretaresse/management-assistent

BBL BB Groen/technisch medewerker recreatiebedijf

BBL BB Werkplaatstimmerman 
Tabel B2.2 (vervolg)

Belangrijkste opleidingen van schoolverlaters die een vervolgopleiding zijn gaan volgen

BOL BB Beveiliging (vervolg)

BBL ZB Eerste verkoper

HBO Pedagogiek

BOL BB Detailhandel/ambulante handel

BBL ZB Detailhandel/ambulante handel

BOL MKF Ondernemer/manager detailhandel

BOL MKF Bedrijfsmanagement motorvoertuigen

BOL MKF Ondernemingsmanager (wegvervoer)

BOL MKF Mode Handel

BOL BB Gastheer/-vrouw

BOL KF Bedrijfsleider/manager in- en verkoop

BBL BB Detailhandel/ambulante handel

BOL BB Horeca, instellingskeuken en contractcatering BBL ZB Zelfstandig werkend kok

BBL ZB Zelfstandig werkend gastheer/-vrouw

BOL MKF Horecaondernemer/-manager

BBL BB Kok

BOL BB Verpleging en verzorging

BOL ZB Sociaal-pedagogisch werk

BBL ZB Verzorgende

BOL ZB Verzorgende

BBL MKF Verpleging en verzorging

HBO Leraar basisonderwijs

BOL ZB Plantenteelt

BOL KF Plantenteelt en management $\quad 20$

BOL ZB Monteur-chauffeur loonwerk $\quad 13$

BOL KF Plantenteelt

BOL ZB Machinist gww

BOL MKF Landbouwtechniek

BOL MKF Bedrijfsadministratief

BOL ZB Detailhandel/ambulante handel

(1)

BOL ZB Bloemschikken

BOL KF Bloemschikken

BBL ZB Bloemschikken

BOL ZB All-round kapper

BOL MKF Vormgever reclame, presentatie en communicatie

BBL KF Bloemschikken

BBL Specialist Bloemschikken

BBL Specialist Groene ruimte

BOL ZB Tuincentrum

BBL ZB Verzorgende

HBO Leraar basisonderwijs

BOL ZB Dierverzorging en veterinaire ondersteuning

BOL KF Dierenzorg

BOL KF Dierenassistent paraveterinair

BOL AB Landbouw

BBL KF Veehouderij

In-service Verpleegkundige A 
Tabel B2.2 (vervolg)

Belangrijkste opleidingen van schoolverlaters die een vervolgopleiding zijn gaan volgen

BOL ZB Groene ruimte

BOL KF Groene ruimte

BOL KF Bos- en natuurbeheer

BOL ZB Toerisme, recreatie en reizen

HBO Leraar basisonderwijs

HBO B Vrijetijdsmanagement

BOL MKF Toerisme, recreatie en reizen

BOL MKF Toeristische informatie

HBO B Marketing management (3-jarig)

HBO B Hotel- en Hospitality Management

BOL BB Gastheer/-vrouw

BOL MKF Assistent marketing en communicatie

BBL MKF Directiesecretaresse/management-assistent

HBO B Sociaal Pedagogische Hulpverlening

BBL ZB Boekhoudkundig medewerker

HBO Kort Marketing management

BOL ZB Verpleging en verzorging

BOL MKF Verpleegkundige

BBL MKF Verpleegkundige

BBL ZB Verzorgende bij inst. voor gezinsverz.

BOL ZB Verpleegkundige

BOL ZB Uiterlijke verzorging

BOL MKF Filiaalbeheerder

BOL ZB Schoonheidsspecialist

HBO Kort Toerisme

BOL ZB Voetverzorger

BOL MKF Reclame, presentatie en communicatie

BOL MKF Mode Handel

BOL MKF Afdelingsmanager

BBL ZB All-round kapper

HBO Leraar basisonderwijs

HBO Biologie en medisch laboratoriumonderzoek

BOL ZB Sociaal pedagogisch werk

HBO Leraar basisonderwijs

HBO Leraar basisonderwijs

BOL MKF Onderwijsassistent

BOL KF Plantenteelt

HBO B Tuinbouw en Akkerbouw

HBO B Bedrijfskunde en Agribusiness

HBO Agrarische bedrijfskunde

BOL MKF Verkoopleider personenautos

HBO Landbouw

HBO Educatie en kennismanagement groene sector

HBO B Bedrijfskunde

BOL KF Veehouderij

HBO B Dier- en veehouderij

HBO Veehouderij

HBO Educatie en kennismanagement groene sector

HBO B Bedrijfskunde en Agribusiness

BOL KF voedingsmiddelentechnologie 
Tabel B2.2 (vervolg)

Belangrijkste opleidingen van schoolverlaters die een vervolgopleiding zijn gaan volgen

BOL KF Bloemschikken

HBO Docent plantenteelt/bloemsierkunst (2e gr.) 19

HBO Tuinbouw

BBL ZB Leidster kindercentra

HBO Landbouw 10

HBO Educatie en kennismanagement groene sector $\quad 10$

HBO B Docent Beeldende Kunst en Vormgeving $\quad 10$

HBO B Communicatiemanagement

BOL KF Dierverzorging en veterinaire ondersteuning

HBO B Dier- en veehouderij

HBO Diermanagement

HBO Fysiotherapie

HBO B Diermanagement

BOL KF Dierenassistent paraveterinair

BOL KF Groene ruimte

HBO Tuin- en landschapsinrichting

\section{BOL KF Milieutoezicht}

HBO B Milieukunde

HBO Milieukunde (technisch)

HBO Milieukunde (agrarisch)

HBO Duaal Milieukunde

HBO Milieutechnologie (agrarische)

HBO Plattelandsvernieuwing

HBO Fysiotherapie

BOL MKF Bouw

HBO Bouwkunde

HBO B Bouwkunde

BOL MKF Grond-, water- en wegenbouw

HBO Civiele techniek

HBO B Civiele Techniek

HBO Bouwkunde

BOL MKF Reclame, presentatie en communicatie

HBO Kunst en cultuur

HBO Visual Marketing in Fashion

HBO B Communication \& Multimedia Design

HBO Mode-, textielvormgeving en styling

HBO Beeldende kunst en vormgeving - vrij

BOL MKF Werktuigbouwkunde

HBO Werktuigbouwkunde

HBO B Werktuigbouwkunde

BOL MKF Motorvoertuigen

HBO Autotechniek

HBO Management, economie en recht

HBO B Bedrijfseconomie

HBO B Commerciële Economie

BOL MKF Energie- en informatietechniek

HBO Elektrotechniek

HBO B Elektrotechniek 
Tabel B2.2 (vervolg)

Belangrijkste opleidingen van schoolverlaters die een vervolgopleiding zijn gaan volgen

BOL MKF Informatietechniek

HBO Informatica

HBO Technische informatica

HBO Bedrijfskundige informatica

10

HBO B Bedrijfskundige Informatica

BOL MKF Graf. techn, communicatie, audiovisueel en multimedia

HBO B Communication \& Multimedia Design

HBO Technische bedrijfskunde

HBO Beeld \& geluid

HBO B Technische Bedrijfskunde

BBL Specialist Grafische techniek, communicatie, audiovisuee

HBO Toerisme en recreatie (bedrijfsmanagement)

HBO Communicatie

HBO Journalistiek

HBO Publiciteits- c.q. grafische vormgeving

BOL MKF Laboratoriumtechniek

HBO Biologie en medisch laboratoriumonderzoek $\quad 15$

HBO B Laboratoriumtechniek 11

HBO B Biologie en Medisch Laboratoriumonderzoek 10

HBO B Chemie $\quad 8$

HBO Chemie

BOL MKF Transport en logistiek

HBO Logistiek en technische vervoerskunde $\quad 62$

HBO B Logistiek en Technische Vervoerskunde 12

BOL MKF Sociaal-juridisch werk 6

HBO Bestuurskunde/overheidsmanagement $\quad 6$

BOL MKF Automatisering

HBO Bedrijfskundige informatica

HBO B Communication \& Multimedia Design $\quad 15$

HBO B Bedrijfskundige Informatica $\quad 7$

HBO Hogere informatica $\quad 6$

HBO B Informatica

BOL MKF Bedrijfsadministratief

HBO B Bedrijfseconomie 18

HBO Bedrijfseconomie $\quad 14$

HBO B Accountancy 14

HBO Accountancy 6

HBO Management, economie en recht $\quad 5$

BOL MKF Commercieel

HBO Commerciele economie

HBO Management, economie en recht

HBO Communicatie

HBO B Financial Services Management

HBO B Commerciële Economie

BOL MKF Economisch-juridisch

HBO Management, economie en recht

23

HBO Recht en openbare orde

HBO B Management, Economie en Recht

17

HBO Sociaal-juridische dienstverlening

HBO Leraar basisonderwijs

11

HBO Culturele en maatschappelijke vorming 
Tabel B2.2 (vervolg)

Belangrijkste opleidingen van schoolverlaters die een vervolgopleiding zijn gaan volgen

BOL MKF Secretarieel

HBO B Office management

HBO Personeel en arbeid

HBO Communicatie

HBO Commerciele economie

BOL MKF Detailhandel/ambulante handel

HBO Commerciele economie

HBO Small business en retail management

HBO Management, economie en recht

HBO B Commerciële Economie

BOL MKF Groothandel/distributie

HBO Commerciele economie

HBO B Commerciële Economie

HBO Management, economie en recht

HBO B Management, Economie en Recht

HBO B International Business and Management Studies

BOL MKF Horeca, instellingskeuken en contractcatering HBO Hoger hotelonderwijs

HBO B Hotel- en Hospitality Management

HBO B Hotelmanagement

HBO Facilitair management

HBO B Facility Management

BOL MKF Toerisme, recreatie en reizen

HBO B Vrijetijdsmanagement

HBO B International Business and Languages

HBO B Toerisme

BOL MKF Assistenten gezondheidszorg

HBO Opleiding tot verpleegkundige

$\mathrm{HBO}$ Opleiding mondhygienist

HBO B Opleiding Mondhygiëne

HBO Ergotherapie

HBO Huidtherapie

BOL MKF Facilitaire dienstverlening

HBO B Facility Management

HBO Facilitair management

HBO B Vrijetijdsmanagement

BOL MKF Sport en bewegen

HBO Fysiotherapie

HBO Leraar VO lichamelijke oefening (1e gr.)

HBO Leraar basisonderwijs

HBO Sport en bewegen

HBO Leraar basisonderwijs

MBO Politie

BOL MKF Verpleging en verzorging

HBO Opleiding tot verpleegkundige

HBO B Opleiding tot Verpleegkundige

HBO Maatschappelijk werk en dienstverlening

BOL MKF Sociaal-pedagogisch werk algemeen

HBO Leraar basisonderwijs 
Tabel B2.2 (vervolg)

Belangrijkste opleidingen van schoolverlaters die een vervolgopleiding zijn gaan volgen

BOL MKF Sociaal-pedagogisch werk algemeen

HBO Pedagogiek

HBO Maatschappelijk werk en dienstverlening

BOL MKF Sociaal-juridisch werk

HBO Personeel en arbeid

HBO Communicatie

HBO Sociaal-juridische dienstverlening

HBO B Sociaal-Juridische Dienstverlening

HBO Leraar basisonderwijs

HBO Recht en openbare orde

HBO B Personeel en Arbeid

BOL Specialist Informatietechniek

HBO Bedrijfswiskunde

HBO Bedrijfskundige informatica

HBO B Informatica

HBO B Communication \& Multimedia Design

BOL Specialist Automatisering

HBO Bedrijfskundige informatica

HBO Informatica

BOL MKF Informatietechniek

HBO Technische informatica

HBO Personeel en arbeid

HBO B Communication \& Multimedia Design

$B B L A B$ Groene ruimte

BBL BB Landbouw

BBL BB Bloemschikken

BBL ZB Bloemschikken

BBL BB Groene ruimte

BBL ZB Vakbekw, Hovenier

BBL BB Horeca, instellingskeuken en contractcatering

BBL ZB Zelfstandig werkend kok

47

BBL ZB Zelfstandig werkend gastheer/-vrouw

$B B L B B$ Verpleging en verzorging

BBL ZB Verzorgende bij inst. voor gezinsverz.

BBL ZB Verzorgende

BBL BB Verpleging en verzorging

BBL ZB Groene ruimte

BBL ZB Boomteelt

BBL BB Medewerker bos- en natuurbeheer

HBO Management

HBO B Land- en watermanagement

HBO B duaal Godsdienst-pastoraal werk 
Tabel B2.2 (vervolg)

Belangrijkste opleidingen van schoolverlaters die een vervolgopleiding zijn gaan volgen

BBL ZB Horeca, instellingskeuken en contractcatering

BBL Specialist Gespecialiseerd kok

BOL MKF Directie-secretaresse/management-assistent

BBL ZB Koudetechniek

BBL MKF Restauratiemedewerker

BBL Specialist Restauratiemedewerker

HBO B Hotelmanagement

Zie ook toelichting bladzijde 15 
Tabel B2.3

Oordeel van schoolverlaters over de aansluiting van de afgesloten opleiding met de vervolgopleiding

\begin{tabular}{lrrr}
\hline Opleidingsrichting & $\begin{array}{r}\text { goed } \\
\%\end{array}$ & $\begin{array}{r}\text { voldoende } \\
\%\end{array}$ & $\begin{array}{r}\text { matig } \\
\%\end{array}$ \\
& & $\begin{array}{r}\text { slech } \\
\%\end{array}$ \\
\hline
\end{tabular}

\section{VMBO}

Theoretische leerweg

Landbouw Gem Iw landbouw en nat.omgeving

Landbouw KB landbouw en nat.omgeving

Landbouw BB landbouw en nat.omgeving

Techniek KB bouwtechniek

Techniek KB voertuigentechniek

Techniek KB electrotechniek

Techniek BB bouwtechniek

Techniek BB metaaltechniek

Techniek BB voertuigentechniek

Techniek BB electrotechniek

Techniek BB overig

Economie KB

Economie KB administratie

Economie KB handel en administratie

Economie BB administratie

Economie BB handel en administratie

Economie BB consumptief

Zorg en Welzijn Gem Iw zorg en welzijn-breed

Zorg en Welzijn KB

Zorg en Welzijn KB verzorging

Zorg en Welzijn KB zorg en welzijn-breed

Zorg en Welzijn BB verzorging

Zorg en Welzijn BB zorg en welzijn-breed

BOL niveau $1 / 2$

BB Motorvoertuigen

BB Informatietechniek

BB Beveiliging

BB Detailhandel/ambulante handel

BB Horeca, instellingskeuken en contractcatering

BB Verpleging en verzorging

$\begin{array}{rr}11 & 5 \\ 20 & 4 \\ 11 & 3 \\ 12 & 7 \\ 7 & 7 \\ 10 & 10 \\ 14 & 6 \\ 5 & 7 \\ 5 & 0 \\ 9 & 0 \\ 0 & 6 \\ 6 & 3 \\ 0 & 10 \\ 27 & 10 \\ 17 & 0 \\ 9 & 5 \\ 0 & 12 \\ 22 & 3 \\ 5 & 0 \\ 56 & 0 \\ 5 & 2 \\ 15 & 5 \\ 5 & 2 \\ 7 & 19\end{array}$

BOL niveau $3 / 4$

ZB Plantenteelt

ZB Bloemschikken

ZB Dierverzorging en veterinaire ondersteuning

ZB Groene ruimte

$Z B$ Toerisme, recreatie en reizen

ZB Verpleging en verzorging

ZB Uiterlijke verzorging

ZB Sociaal pedagogisch werk

KF Plantenteelt

KF Veehouderij

$\mathrm{KF}$ voedingsmiddelentechnologie

KF Bloemschikken

KF Dierverzorging en veterinaire ondersteuning

KF Groene ruimte

KF Milieutoezicht

MKF Bouw

MKF Grond-, water- en wegenbouw

MKF Reclame, presentatie en communicatie

MKF Werktuigbouwkunde

MKF Motorvoertuigen

MKF Energie- en informatietechniek

MKF Informatietechniek

MKF Graf. techn, communicatie, audiovisueel en multimedia

MKF Laboratoriumtechniek

$\begin{array}{rrr}42 & 9 & 16 \\ 8 & 40 & 0 \\ 26 & 15 & 10 \\ 40 & 18 & 0 \\ 29 & 7 & 0 \\ 31 & 14 & 0\end{array}$


Tabel B2.3 (vervolg)

Oordeel van schoolverlaters over de aansluiting van de afgesloten opleiding met de vervolgopleiding

\begin{tabular}{|c|c|c|c|c|}
\hline Opleidingsrichting & $\begin{array}{r}\text { goed } \\
\%\end{array}$ & $\begin{array}{r}\text { voldoende } \\
\%\end{array}$ & $\begin{array}{r}\text { matig } \\
\%\end{array}$ & $\begin{array}{r}\text { slecht } \\
\%\end{array}$ \\
\hline MKF Transport en logistiek & 7 & 51 & 34 & 8 \\
\hline MKF Automatisering & 15 & 39 & 28 & 19 \\
\hline MKF Bedrijfsadministratief & 48 & 30 & 18 & 4 \\
\hline MKF Commercieel & 36 & 41 & 14 & 9 \\
\hline MKF Economisch-juridisch & 14 & 59 & 17 & 10 \\
\hline MKF Secretarieel & 27 & 40 & 16 & 16 \\
\hline MKF Detailhandel/ambulante handel & 27 & 44 & 21 & 7 \\
\hline MKF Groothandel/distributie & 54 & 17 & 25 & 4 \\
\hline MKF Horeca, instellingskeuken en contractcatering & 45 & 36 & 16 & 4 \\
\hline MKF Toerisme, recreatie en reizen & 45 & 39 & 7 & 9 \\
\hline MKF Assistenten gezondheidszorg & 39 & 37 & 17 & 7 \\
\hline MKF Facilitaire dienstverlening & 19 & 30 & 40 & 11 \\
\hline MKF Sport en bewegen & 49 & 38 & 9 & 5 \\
\hline MKF Verpleging en verzorging & 41 & 48 & 10 & 1 \\
\hline MKF Sociaal-pedagogisch werk algemeen & 44 & 34 & 17 & 6 \\
\hline MKF Sociaal-juridisch werk & 38 & 44 & 16 & 2 \\
\hline Specialist Informatietechniek & 27 & 13 & 53 & 7 \\
\hline Specialist Automatisering & 16 & 27 & 22 & 35 \\
\hline
\end{tabular}

Zie ook toelichting bladzijde 16 
Tabel B2.4

Doorstroom van schoolverlaters naar kenniscentrum beroepsonderwijs bedrijfsleven

VMBO Theoretische leerweg

OVDB

Ecabo

Kenteq

KC Handel

LOB HTV

VMBO Landbouw Gem Iw landbouw en nat.omgeving

Aequor

OVDB

Kenteq

LOB HTV

VMBO Landbouw KB landbouw en nat.omgeving

Aequor

OVDB

Ecabo

LOB HTV

VMBO Landbouw BB landbouw en nat.omgeving

Aequor

OVDB

Ecabo

KC Handel

LOB HTV

VMBO Techniek KB bouwtechniek

Bouwradius LOB

SH\&M

Innovam

VMBO Techniek KB voertuigentechniek

Innovam

Transport \& Logistiek

Kenteq

VMBO Techniek KB electrotechniek

Kenteq

Innovam

VMBO Techniek BB bouwtechniek

Bouwradius LOB

$\mathrm{SH} \& \mathrm{M}$

Savantis

VMBO Techniek BB voertuigentechniek

Innovam

Kenteq

SB

Transport \& Logistiek

VMBO Techniek BB electrotechniek

Kenteq

Ecabo

KC Handel 
Tabel B2.4 (vervolg)

Doorstroom van schoolverlaters naar kenniscentrum beroepsonderwijs bedrijfsleven

VMBO Economie KB administratie

Ecabo

OVDB

Kenteq

LOB HTV

VMBO Economie KB handel en administratie

Ecabo

KC Handel

OVDB

LOB HTV

VMBO Economie BB administratie

Ecabo

VMBO Economie BB handel en administratie

Ecabo

Transport \& Logistiek

KC Handel

VMBO Economie BB consumptief

LOB HTV

VMBO Zorg en Welzijn Gem Iw zorg en welzijn-breed

OVDB

Ecabo

KOC Nederland

LOB HTV

VMBO Zorg en Welzijn KB verzorging

OVDB

KOC Nederland

VMBO Zorg en Welzijn KB zorg en welzijn-breed

OVDB

KOC Nederland

VMBO Zorg en Welzijn BB verzorging

OVDB

VMBO Zorg en Welzijn BB zorg en welzijn-breed

OVDB

KOC Nederland

Ecabo

LOB HTV

BOL BB Motorvoertuigen

Innovam

Bouwradius LOB

Vocar

BOL BB Detailhandel/ambulante handel

KC Andel

LOB HTV

Vocar

Transport \& Logistiek

Aequor 
Tabel B2.4 (vervolg)

Doorstroom van schoolverlaters naar kenniscentrum beroepsonderwijs bedrijfsleven

BOL BB Horeca, instellingskeuken en contractcatering LOB HTV

OVDB

BOL BB Verpleging en verzorging

OVDB

BOL ZB Dierverzorging en veterinaire ondersteuning

Aequor

OVDB

In-service verpleegkundige A

BOL ZB Verpleging en verzorging

BOL ZB Uiterlijke verzorging

KOC Nederland

KC Handel

Savantis

LOB HTV

BOL ZB Sociaal pedagogisch werk

OVDB

Ecabo

BOL MKF Sociaal-pedagogisch werk algemeen

OVDB

SH\&M

Lift Group

KOC Nederland

BBL BB Groene ruimte

Aequor

BBL BB Horeca, instellingskeuken en contractcatering LOB HTV

$B B L B B$ Verpleging en verzorging OVDB

Zie ook toelichting bladzijde 18 
Tabel B3.1

Werkloosheid en gemiddelde intredewerkloosheid van schoolverlaters die zich aanbieden op de arbeidsmarkt

\begin{tabular}{|c|c|c|c|c|c|c|c|c|}
\hline \multirow[t]{2}{*}{ Opleidingsrichting } & \multirow{2}{*}{$\begin{array}{r}\text { aanbieden } \\
\text { op arbeids- } \\
\text { markt } \\
\%\end{array}$} & \multirow{2}{*}{$\begin{array}{r}\text { werk- } \\
\text { loosheid } \\
\%\end{array}$} & \multicolumn{5}{|c|}{ werkloos tijdens intredeperiode in klassen } & \multirow{2}{*}{$\begin{array}{r}\text { intrede- } \\
\text { werk- } \\
\text { loosheid } \\
\text { maanden }\end{array}$} \\
\hline & & & $\begin{array}{r}0 \text { mnd. } \\
\%\end{array}$ & $\begin{array}{r}1-3 \text { mnd. } \\
\%\end{array}$ & $\begin{array}{r}\text { 4-6 mnd., } \\
\%\end{array}$ & $\begin{array}{r}\text { 7-12 mnd. } \\
\%\end{array}$ & $\begin{array}{r}\geq 13 \text { mnd. } \\
\%\end{array}$ & \\
\hline \multicolumn{9}{|l|}{ Vмво } \\
\hline Theoretische leerweg & 11 & 12 & 87 & 7 & 5 & 1 & 0 & 0,5 \\
\hline Landbouw Gem Iw landbouw en nat.omgeving & 16 & 16 & 81 & 15 & 0 & 0 & 4 & 1,1 \\
\hline Landbouw KB landbouw en nat.omgeving & 20 & 8 & 88 & 1 & 10 & 0 & 1 & 0,6 \\
\hline Landbouw BB landbouw en nat.omgeving & 47 & 8 & 79 & 11 & 7 & 3 & 0 & 0,9 \\
\hline Techniek KB bouwtechniek & 45 & 0 & 100 & 0 & 0 & 0 & 0 & 0,0 \\
\hline Techniek KB voertuigentechniek & 83 & 5 & 95 & 0 & 5 & 0 & 0 & 0,2 \\
\hline Techniek KB electrotechniek & 43 & 0 & 82 & 6 & 6 & 6 & 0 & 1,2 \\
\hline Techniek KB overig & 23 & 0 & 83 & 17 & 0 & 0 & 0 & 0,3 \\
\hline Techniek BB bouwtechniek & 76 & 0 & 91 & 3 & 6 & 0 & 0 & 0,3 \\
\hline Techniek BB metaaltechniek & 82 & 6 & 89 & 6 & 6 & 0 & 0 & 0,3 \\
\hline Techniek BB voertuigentechniek & 93 & 0 & 96 & 4 & 0 & 0 & 0 & 0,1 \\
\hline Techniek BB electrotechniek & 62 & 10 & 98 & 0 & 2 & 0 & 0 & 0,1 \\
\hline Techniek BB overig & 91 & 0 & 97 & 3 & 0 & 0 & 0 & 0,1 \\
\hline Economie KB & 33 & 0 & 70 & 30 & 0 & 0 & 0 & 0,6 \\
\hline Economie KB administratie & 19 & 0 & 100 & 0 & 0 & 0 & 0 & 0,0 \\
\hline Economie KB handel en administratie & 38 & 6 & 82 & 12 & 6 & 0 & 0 & 0,4 \\
\hline Economie BB administratie & 25 & 14 & 83 & 17 & 0 & 0 & 0 & 0,2 \\
\hline Economie BB handel en verkoop & 55 & 0 & 87 & 13 & 0 & 0 & 0 & 0,4 \\
\hline Economie BB handel en administratie & 23 & 14 & 86 & 14 & 0 & 0 & 0 & 0,4 \\
\hline Economie BB consumptief & 63 & 14 & 94 & 6 & 0 & 0 & 0 & 0,1 \\
\hline Zorg en Welzijn Gem Iw zorg en welzijn-breed & 2 & 0 & 100 & 0 & 0 & 0 & 0 & 0,0 \\
\hline Zorg en Welzijn KB verzorging & 33 & 7 & 79 & 0 & 21 & 0 & 0 & 1,2 \\
\hline Zorg en Welzijn KB zorg en welzijn-breed & 18 & 0 & 89 & 0 & 11 & 0 & 0 & 0,6 \\
\hline Zorg en Welzijn BB verzorging & 28 & 0 & 91 & 9 & 0 & 0 & 0 & 0,3 \\
\hline Zorg en Welzijn BB zorg en welzijn-breed & 32 & 10 & 89 & 11 & 0 & 0 & 0 & 0,3 \\
\hline
\end{tabular}


Tabel B3.1 (vervolg)

Werkloosheid en gemiddelde intredewerkloosheid van schoolverlaters die zich aanbieden op de arbeidsmarkt

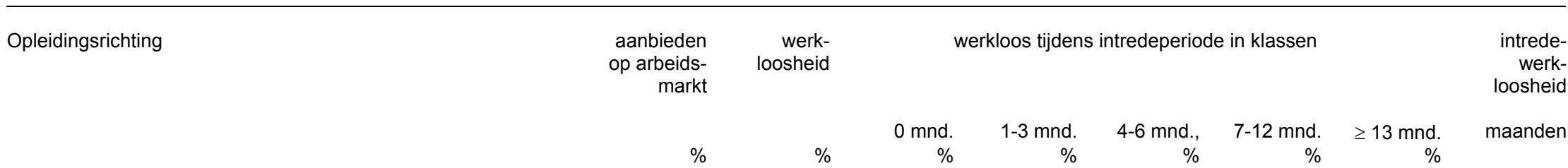

\section{BOL niveau $1 / 2$}

$A B$ Beveiliging

AB Secretarieel

BB Bloemschikken

BB Dierverzorging en veterinaire ondersteuning

BB Motorvoertuigen

BB Informatietechniek

BB Scheepvaart

BB Bedrijfsadministratie

BB Beveiliging

BB Detailhandel/ambulante handel

BB Horeca, instellingskeuken en contractcatering

BB Toerisme, recreatie en reizen

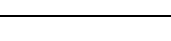

maanden

BB Verpleging en verzorging

70
52
80
60
90
40
82
57
67
60
53
78
76
52

$\begin{array}{rr}24 & 75 \\ 57 & 5 \\ 25 & 58 \\ 15 & 67 \\ 22 & 78 \\ 55 & 55 \\ 0 & 100 \\ 27 & 66 \\ 21 & 72 \\ 41 & 63 \\ 16 & 97 \\ 8 & 85 \\ 23 & 62 \\ 21 & \end{array}$

$\begin{array}{rr}75 & \\ 50 & \\ 58 & \\ 67 & 25 \\ 78 & \\ 55 & \\ 100 & \\ 66 & \\ 72 & \\ 63 & 17 \\ 97 & 1 \\ 85 & \\ 62 & \\ 68 & 15\end{array}$

$\begin{array}{rr}7 & \\ 17 & \\ 25 & \\ 26 & \\ 7 & \\ 9 & 15 \\ 0 & 14 \\ 5 & \\ 12 & 7 \\ 16 & 8 \\ 3 & \\ 6 & \\ 15 & \\ 12 & \\ & \end{array}$

ZB Veehouderij

ZB Dierverzorging en veterinaire ondersteuning

ZB Paardenhouderij en paardensport

ZB Paardenhouderi

ZB Graf. techn, communicatie, audiovisueel en multimedia

ZB Scheepvaart

ZB Automatisering

ZB Bedrijfsadministratief

ZB Toerisme, recreatie en reizen

$\begin{array}{rrr}70 & 1 & 67 \\ 76 & 0 & 100 \\ 85 & 6 & 87 \\ 70 & 29 & 66 \\ 83 & 14 & 74 \\ 71 & 20 & 72 \\ 70 & 49 & 25 \\ 92 & 0 & 87 \\ 63 & 40 & 30 \\ 81 & 9 & 92 \\ 88 & 10 & 59\end{array}$

$\begin{array}{rrr}26 & 6 & 1 \\ 0 & 0 & 0 \\ 11 & 2 & 0 \\ 15 & 14 & 2 \\ 19 & 0 & 0 \\ 12 & 10 & 4 \\ 13 & 6 & 13 \\ 0 & 13 & 0 \\ 0 & 20 & 30 \\ 4 & 0 & 4 \\ 23 & 14 & 5\end{array}$


Tabel B3.1 (vervolg)

Werkloosheid en gemiddelde intredewerkloosheid van schoolverlaters die zich aanbieden op de arbeidsmarkt

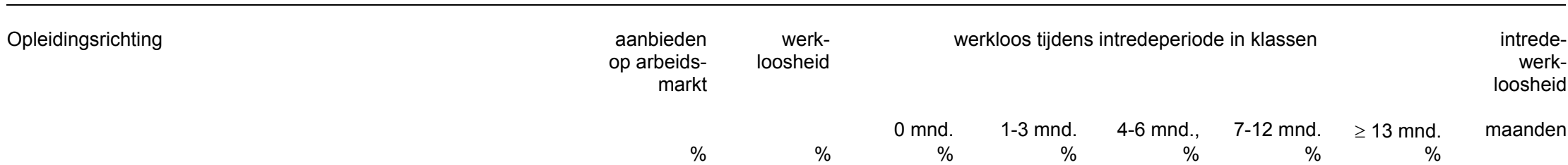

BOL niveau $3 / 4$ (vervolg)

ZB Verpleging en verzorging

ZB Uiterlijke verzorging

ZB Sociaal pedagogisch werk

KF Plantenteelt

KF Veehouderij

KF Bloemschikken

KF Dierverzorging en veterinaire ondersteuning

KF Paardenhouderij en paardensport

KF Groene ruimte

KF Milieutoezicht

MKF Techniek

MKF Bouw

MKF Grond-, water- en wegenbouw

MKF Beschermings- en afwerkingstechnieken

MKF Reclame, presentatie en communicatie

MKF Operationele techniek

MKF Werktuigbouwkunde

MKF Motorvoertuigen

MKF Motorvoertuigen en carrosserietechniek

MKF Energie- en informatiotechniek

MKF Energietechniek

MKF Informatietechniek

MKF Edelsmeden

MKF Graf techn, communicatie, audiovisueel en multimedia

MKF Laboratoriumtechniek

maanden

MKF Haven en vervoer

$\begin{array}{rrr}84 & 4 & 92 \\ 71 & 6 & 78 \\ 53 & 20 & 82 \\ 45 & 0 & 85 \\ 44 & 10 & 93 \\ 19 & 0 & 78 \\ 54 & 6 & 88 \\ 51 & 7 & 73 \\ 65 & 0 & 79 \\ 60 & 1 & 66 \\ 49 & 23 & 73 \\ 40 & 0 & 83 \\ 34 & 12 & 74 \\ 45 & 8 & 72 \\ 60 & 0 & 79 \\ 44 & 0 & 79 \\ 92 & 12 & 85 \\ 42 & 9 & 80 \\ 54 & 10 & 90 \\ 75 & 0 & 100 \\ 33 & 0 & 87 \\ 56 & 7 & 57 \\ 31 & 13 & 56 \\ 74 & 20 & 72 \\ 46 & 12 & 72 \\ 46 & 17 & 77 \\ 87 & 8 & 62\end{array}$

$\begin{array}{rr}6 & 1 \\ 8 & 8 \\ 7 & 4 \\ 4 & 12 \\ 7 & 0 \\ 22 & 0 \\ 3 & 0 \\ 7 & 14 \\ 21 & 0 \\ 28 & 5 \\ 6 & 15 \\ 17 & 0 \\ 10 & 4 \\ 10 & 6 \\ 0 & 21 \\ 17 & 0 \\ 5 & 10 \\ 13 & 6 \\ 0 & 5 \\ 0 & 0 \\ 7 & 7 \\ 21 & 21 \\ 24 & 10 \\ 10 & 7 \\ 5 & 12 \\ 7 & 13 \\ 8 & 15\end{array}$


Tabel B3.1 (vervolg)

Werkloosheid en gemiddelde intredewerkloosheid van schoolverlaters die zich aanbieden op de arbeidsmarkt

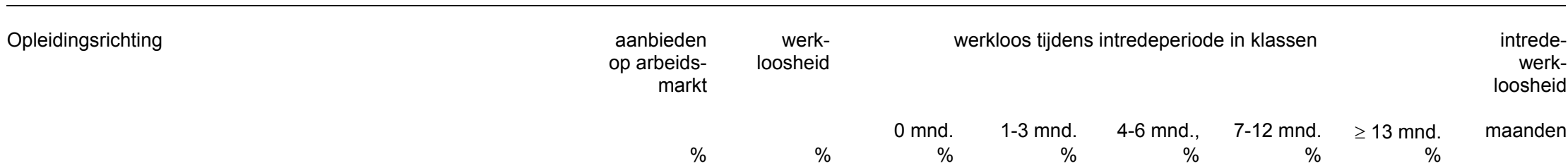

BOL niveau $3 / 4$ (vervolg)

MKF Scheepvaart

MKF Transport en logistiek

MKF Automatisering

MKF Bedrijfsadministratief

MKF Commerciee

$\% \quad \% \quad \% \quad \% \quad \%$

MKF Economisch-juridisch

MKF Economisch-jur

MKF Detailhandel/ambulante handel

MKF Groothandel/distributie

MKF Horeca, instellingskeuken en contractcatering

MKF Toerisme, recreatie en reizen

MKF Toerisme, recreatie en reizen

MKF Assistenten gezondheidszor

MKF Sport en bewegen

MKF Verpleging en verzorging

MKF Sociaal-cultureel werker

MKF Sociaal-pedagogisch werk algemeen

MKF Sociaal-juridisch werk

Specialist Informatietechniek

Specialist Automatisering

65

$\begin{array}{lrl}65 & 4 & 87 \\ 60 & 7 & 87 \\ 40 & 23 & 47 \\ 36 & 5 & 68 \\ 36 & 13 & 61 \\ 24 & 40 & 60 \\ 55 & 11 & 68 \\ 41 & 13 & 82 \\ 39 & 8 & 91 \\ 55 & 10 & 80 \\ 47 & 11 & 65 \\ 69 & 6 & 88 \\ 43 & 24 & 58 \\ 39 & 7 & 67 \\ 76 & 4 & 89 \\ 48 & 30 & 70 \\ 47 & 10 & 79 \\ 31 & 20 & 66 \\ 11 & 0 & 73 \\ 39 & 0 & 83 \\ & & \\ 68 & 7 & 97 \\ 95 & 13 & 80 \\ 96 & 0 & 98 \\ 93 & 0 & 96 \\ 87 & 2 & 88\end{array}$

BBL niveau 1/2

$A B$ Horeca, instellingskeuken en contractcatering

$A B$ Verpleging en verzorging

BB Bloemschikken

$\begin{array}{rr}13 & \\ 4 & 1 \\ 23 & 13 \\ 14 & 12 \\ 14 & 17 \\ 31 & 0 \\ 19 & 7 \\ 10 & 6 \\ 9 & 0 \\ 11 & 5 \\ 20 & 11 \\ 7 & 1 \\ 18 & 24 \\ 22 & 5 \\ 6 & 2 \\ 30 & 0 \\ 12 & 5 \\ 7 & 7 \\ 0 & 0 \\ 8 & 10 \\ & \end{array}$

\section{de-

-

sheid 
Tabel B3.1 (vervolg)

Werkloosheid en gemiddelde intredewerkloosheid van schoolverlaters die zich aanbieden op de arbeidsmarkt

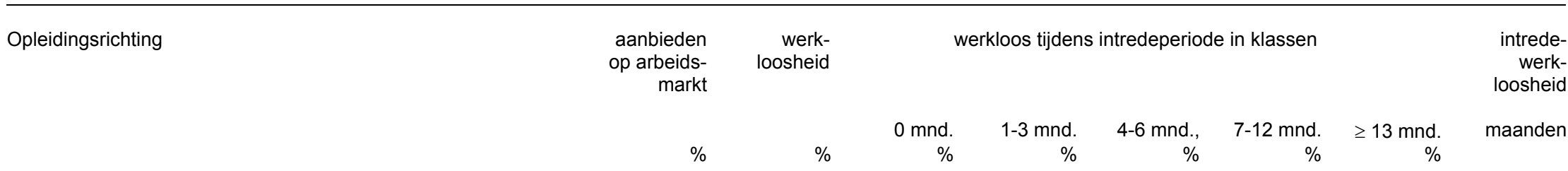

BBL niveau 1/2 (vervolg)

BB Dierverzorging en veterinaire ondersteuning

BB Groene ruimte

BB Bouw

BB Installatie-, service- en onderhoudstechniek

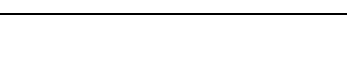

BB Detailhandel/ambulante handel

BB Horeca, instellingskeuken en contractcatering

BB Facilitaire dienstverlening

BB Verpleging en verzorging

$\begin{array}{rrr}93 & 8 & 92 \\ 99 & 2 & 92 \\ 96 & 4 & 81 \\ 93 & 8 & 92 \\ 91 & 5 & 89 \\ 100 & 0 & 100 \\ 82 & 0 & 93 \\ 100 & 6 & 81 \\ 100 & 0 & 100 \\ 98 & 10 & 95\end{array}$

92
92
81
92
89
00
93
81
00
95

(1)

BBL niveau $3 / 4$

ZB Plantenteelt

ZB Bloemschikken

ZB Groene ruimte

ZB Bouw

ZB Motorvoertuigen

ZB Horeca, instellingskeuken en contractcatering

$Z B$ Verpleging en verzorging

ZB Sociaal-pedagogisch werk

KF Groene ruimte

MKF Detailhandel/ambulante handel

MKF Horeca, instellingskeuken en contractcatering

$\begin{array}{rrr}94 & 0 & 96 \\ 97 & 1 & 85 \\ 96 & 3 & 83 \\ 100 & 0 & 87 \\ 100 & 0 & 100 \\ 94 & 0 & 93 \\ 98 & 5 & 98 \\ 79 & 4 & 83 \\ 91 & 0 & 98 \\ 68 & 20 & 93 \\ 78 & 4 & 76\end{array}$

$\begin{array}{rr}96 & 4 \\ 85 & 7 \\ 83 & 15 \\ 87 & 12 \\ 100 & 0 \\ 93 & 7 \\ 98 & 1 \\ 83 & 2 \\ 98 & 0 \\ 93 & 0 \\ 76 & 20\end{array}$

$\begin{array}{rrrll}8 & 0 & 0 & 0 & 0,2 \\ 6 & 2 & 1 & 0 & 0,2 \\ 8 & 8 & 4 & 0 & 0,8 \\ 8 & 0 & 0 & 0 & 0,1 \\ 0 & 11 & 0 & 0 & 0,6 \\ 0 & 0 & 0 & 0 & 0,0 \\ 7 & 0 & 0 & 0 & 0,1 \\ 14 & 3 & 1 & 0 & 0,5 \\ 0 & 0 & 0 & 0 & 0,0 \\ 0 & 0 & 3 & 3 & 1,3\end{array}$


Tabel B3.1 (vervolg)

Werkloosheid en gemiddelde intredewerkloosheid van schoolverlaters die zich aanbieden op de arbeidsmarkt

\begin{tabular}{|c|c|c|c|c|c|c|c|c|}
\hline \multirow[t]{2}{*}{ Opleidingsrichting } & \multirow{2}{*}{$\begin{array}{r}\text { aanbieden } \\
\text { op arbeids- } \\
\text { markt }\end{array}$} & \multirow{2}{*}{$\begin{array}{r}\text { werk- } \\
\text { loosheid } \\
\%\end{array}$} & \multicolumn{5}{|c|}{ werkloos tijdens intredeperiode in klassen } & \multirow{2}{*}{$\begin{array}{r}\text { intrede- } \\
\text { werk- } \\
\text { loosheid } \\
\text { maanden }\end{array}$} \\
\hline & & & $\begin{array}{r}0 \text { mnd. } \\
\%\end{array}$ & $\begin{array}{r}1-3 \text { mnd. } \\
\%\end{array}$ & $\begin{array}{r}\text { 4-6 mnd., } \\
\%\end{array}$ & $\begin{array}{r}\text { 7-12 mnd. } \\
\%\end{array}$ & $\begin{array}{r}\geq 13 \text { mnd. } \\
\%\end{array}$ & \\
\hline \multicolumn{9}{|l|}{ BBL niveau 3/4 (vervolg) } \\
\hline MKF Verpleging en verzorging & 98 & 1 & 99 & 1 & 0 & 0 & 0 & 0,0 \\
\hline MKF Sociaal-pedagogisch werk & 90 & 3 & 92 & 6 & 3 & 0 & 0 & 0,3 \\
\hline
\end{tabular}

Zie ook toelichting bladzijde 21 
Tabel B3.2

Aard van het dienstverband van werkende schoolverlaters

\begin{tabular}{|c|c|c|c|c|c|c|}
\hline Opleidingsrichting & $\begin{array}{r}\text { leer/werk- } \\
\text { overeen- } \\
\text { komst } \\
\%\end{array}$ & $\begin{array}{r}\text { uitzend-, } \\
\text { oproepkracht } \\
\%\end{array}$ & $\begin{array}{r}\text { loondienst } \\
\text { werkgever } \\
\%\end{array}$ & $\begin{array}{r}\text { gesubsidieerde } \\
\text { arbeid (WIW) } \\
\%\end{array}$ & $\begin{array}{r}\text { bedrijf } \\
\text { ouders/ } \\
\text { partner } \\
\%\end{array}$ & $\begin{array}{r}\text { eigen bedrijf/ } \\
\text { free-lance } \\
\%\end{array}$ \\
\hline
\end{tabular}

\section{VMBO}

Theoretische leerwe

Landbouw Gem Iw landbouw en nat.omgeving

Landbouw KB landbouw en nat.omgeving

Landbouw BB landbouw en nat.omgeving

Techniek KB bouwtechniek

Techniek KB voertuigentechniek

Techniek KB electrotechniek

Techniek BB bouwtechniek

Techniek BB metaaltechniek

Techniek BB voertuigentechniek

Economie KB handel en administratie

Economie BB consumptief

Zorg en Welzijn KB verzorging

$\begin{array}{ll}51 & \\ 70 & 6 \\ 61 & \\ 55 & \\ 80 & \\ 56 & \\ 65 & \\ 50 & \\ 53 & \\ 70 & \\ 24 & \\ 65 & 6 \\ 57 & \end{array}$

BOL niveau $1 / 2$

$\mathrm{AB}$ Beveiliging

BB Motorvoertuigen

BB Informatietechniek

BB Bedrifsadministratie

BB Beveiliging

BB Secretarieel

BB Detailhandel/ambulante handel

BB Horeca, instellingskeuken en contractcatering

BB Verpleging en verzorging

$\begin{array}{rr}15 & 14 \\ 73 & 0 \\ 14 & 11 \\ 17 & 8 \\ 12 & 0 \\ 8 & 17 \\ 43 & 0 \\ 72 & 1 \\ 22 & 3\end{array}$

40
26
35
38
12
39
30
44
41
30
65
31
43

\section{BOL niveau 3/4}

ZB Plantenteelt

ZB Bloemschikken

0
0
1
0
0
0
0
0
0
0
0
0
0

$\begin{array}{rr}18 & 9 \\ 5 & 5\end{array}$

5
20

9
5
8

71
27
75
57
87
74
46
27
71

0
12
0
0
0
0
2

64

68

$\begin{array}{ll}1 & 1 \\ 4 & 0 \\ 0 & 1 \\ 2 & 0 \\ 8 & 0 \\ 6 & 0 \\ 6 & 0 \\ 3 & 0 \\ 0 & 0 \\ 0 & 0 \\ 6 & 0 \\ 0 & 0 \\ 0 & 0\end{array}$

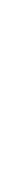


Tabel B3.2 (vervolg)

Aard van het dienstverband van werkende schoolverlaters

\begin{tabular}{|c|c|c|c|c|c|c|}
\hline Opleidingsrichting & $\begin{array}{r}\text { leer/werk- } \\
\text { overeen- } \\
\text { komst } \\
\%\end{array}$ & $\begin{array}{r}\text { uitzend-, } \\
\text { oproepkracht } \\
\%\end{array}$ & $\begin{array}{r}\text { loondienst } \\
\text { werkgever } \\
\%\end{array}$ & $\begin{array}{r}\text { gesubsidieerde } \\
\text { arbeid (WIW) } \\
\%\end{array}$ & $\begin{array}{r}\text { bedrijf } \\
\text { ouders/ } \\
\text { partner } \\
\%\end{array}$ & $\begin{array}{r}\text { eigen bedrijf/ } \\
\text { free-lance } \\
\%\end{array}$ \\
\hline
\end{tabular}

BOL niveau 3/4 (vervolg)

ZB Dierverzorging en veterinaire ondersteuning

ZB Paardenhouderij en paardensport

ZB Groene ruimte

ZB Scheepvaart

ZB Toerisme, recreatie en reizen

ZB Verpleging en verzorging

ZB Uiterlijke verzorging

ZB Sociaal pedagogisch werk

KF Plantenteelt

KF Veehouderij

KF Bloemschikken

KF Dierverzorging en veterinaire ondersteuning

KF Paardenhouderij en paardensport

KF Groene ruimte

KF Milieutoezicht

MKF Bouw

MKF Grond-, water- en wegenbouw

MKF Reclame, presentatie en communicatie

MKF Operationele techniek

MKF Werktuigbouwkunde

MKF Motorvoertuigen

MKF Energie- en informatietechniek

MKF Informatietechniek

MKF Edelsmeden

MKF Graf. techn, communicatie, audiovisueel en multimedia

MKF Laboratoriumtechniek

MKF Scheepvaart

MKF Transport en logistiek

MKF Automatisering

$\begin{array}{rr}7 & \\ 0 & 10 \\ 6 & 4 \\ 0 & 15 \\ 1 & 6 \\ 21 & 6 \\ 0 & 2 \\ 0 & 7 \\ 0 & 7 \\ 0 & 19 \\ 9 & 7 \\ 10 & 0 \\ 22 & 5 \\ 3 & 0 \\ 8 & 11 \\ 8 & 8 \\ 0 & 4 \\ 0 & 21 \\ 0 & 0 \\ 0 & 3 \\ 11 & 10 \\ 7 & 0 \\ 10 & 20 \\ 0 & 6 \\ 6 & 0 \\ 14 & 16 \\ 3 & 0 \\ 1 & 4 \\ 0 & 0 \\ & 32\end{array}$

$\begin{array}{ll}83 & 0 \\ 82 & 6 \\ 69 & 0 \\ 91 & 0 \\ 93 & 0 \\ 76 & 0 \\ 85 & 0 \\ 93 & 0 \\ 60 & 0 \\ 77 & 0 \\ 89 & 0 \\ 85 & 0 \\ 78 & 0 \\ 74 & 0 \\ 85 & 0 \\ 86 & 0 \\ 79 & 0 \\ 92 & 0 \\ 97 & 0 \\ 85 & 0 \\ 89 & 0 \\ 67 & 0 \\ 75 & 0 \\ 87 & 0 \\ 78 & 0 \\ 86 & 0 \\ 93 & 0 \\ 98 & 0 \\ 68 & 0\end{array}$


Tabel B3.2 (vervolg)

Aard van het dienstverband van werkende schoolverlaters

\begin{tabular}{|c|c|c|c|c|c|c|}
\hline Opleidingsrichting & $\begin{array}{r}\text { leer/werk- } \\
\text { overeen- } \\
\text { komst } \\
\%\end{array}$ & $\begin{array}{r}\text { uitzend-, } \\
\text { oproepkracht } \\
\%\end{array}$ & $\begin{array}{r}\text { loondienst } \\
\text { werkgever } \\
\%\end{array}$ & $\begin{array}{r}\text { gesubsidieerde } \\
\text { arbeid (WIW) } \\
\%\end{array}$ & $\begin{array}{r}\text { bedrijf } \\
\text { ouders/ } \\
\text { partner } \\
\%\end{array}$ & $\begin{array}{r}\text { eigen bedrijf } / \\
\text { free-lance } \\
\%\end{array}$ \\
\hline
\end{tabular}

BOL niveau 3/4 (vervolg)

MKF Bedriifsadministratief

MKF Commerciee

MKF Secretarieel

MKF Detailhandel/ambulante handel

MKF Horeca, instellingskeuken en contractcatering

MKF Toerisme, recreatie en reizen

MKF Assistenten gezondheidszorg

MKF Facilitaire dienstverlening

MKF Sport en bewegen

MKF Verpleging en verzorging

MKF Sociaal-pedagogisch werk algemeen

MKF Sociaal-juridisch werk

13
3
0
11
7
2
5
8
6
13
11

14
13
12
4
1
6
0
7
8
1
5
10

$\begin{array}{ll}72 & 0 \\ 82 & 0 \\ 85 & 2 \\ 83 & 0 \\ 92 & 0 \\ 91 & 0 \\ 95 & 0 \\ 85 & 0 \\ 84 & 0 \\ 86 & 0 \\ 83 & 1 \\ 90 & 0\end{array}$

BBL niveau $1 / 2$

AB Groene

AB Grom instellingskeuken en contractcatering

$A B$ Verpleging en verzorging

BB Plantenteelt

BB Bloemschikken

BB Groene ruimte

BB Bouw

BB Motorvoertuigen

BB Installatie-, service- en onderhoudstechniek

BB Wegvervoer

BB Detailhandel/ambulante handel

BB Horeca, instellingskeuken en contractcatering

BB Facilitaire dienstverlening

$\begin{array}{rrrrrr}9 & 2 & 83 & 6 & 0 & 0 \\ 21 & 0 & 79 & 0 & 0 & 0 \\ 0 & 0 & 100 & 0 & 0 & 0 \\ 9 & 2 & 89 & 0 & 0 & 0 \\ 31 & 0 & 68 & 0 & 2 & 0 \\ 19 & 2 & 78 & 1 & 0 & 1 \\ 38 & 0 & 62 & 0 & 0 & 0 \\ 0 & 8 & 83 & 0 & 0 & 0 \\ 44 & 0 & 56 & 0 & 0 & 0 \\ 0 & 1 & 92 & 0 & 7 & 0 \\ 14 & 0 & 86 & 0 & 0 & 3 \\ 46 & 3 & 48 & 0 & 0 & 0 \\ 0 & 0 & 100 & 0 & 0 & 3 \\ 19 & 0 & 76 & 1 & 0 & 0\end{array}$

BB Verpleging

0
2
0
0
0
0
0
0
0
1
0

6
0
0
0
0
1
0
0
0
0
0
0
0
1

0
0
0
2
0
0
0
0
3
0
0
0
0
0
0
0
1
0
0
0
0
3
0


Tabel B3.2 (vervolg)

Aard van het dienstverband van werkende schoolverlaters

\begin{tabular}{|c|c|c|c|c|c|c|}
\hline Opleidingsrichting & $\begin{array}{r}\text { leer/werk- } \\
\text { overeen- } \\
\text { komst } \\
\%\end{array}$ & $\begin{array}{r}\text { uitzend-, } \\
\text { oproepkracht } \\
\%\end{array}$ & $\begin{array}{r}\text { loondienst } \\
\text { werkgever } \\
\%\end{array}$ & $\begin{array}{r}\text { gesubsidieerde } \\
\text { arbeid (WIW) } \\
\%\end{array}$ & $\begin{array}{r}\text { bedrijf } \\
\text { ouders/ } \\
\text { partner } \\
\%\end{array}$ & $\begin{array}{r}\text { eigen bedrijf/ } \\
\text { free-lance } \\
\%\end{array}$ \\
\hline
\end{tabular}

BBL niveau $3 / 4$

ZB Plantenteelt

ZB Bloemschikken

ZB Groene ruimte

ZB Motorvoertuigen

ZB Horeca, instellingskeuken en contractcatering

ZB Verpleging en verzorging

ZB Sociaal-pedagogisch werk

MKF Detailhandel/ambulante handel

MKF Horeca, instellingskeuken en contractcatering

MKF Verpleging en verzorging

MKF Sociaal-pedagogisch werk

\begin{tabular}{rrrrrr}
5 & 0 & 89 & 0 & 0 & 6 \\
4 & 0 & 96 & 0 & 0 & 0 \\
7 & 1 & 91 & 0 & 0 & 1 \\
0 & 0 & 100 & 0 & 0 & 0 \\
3 & 0 & 96 & 0 & 0 & 0 \\
4 & 0 & 96 & 0 & 0 & 0 \\
0 & 2 & 92 & 6 & 0 & 0 \\
0 & 9 & 91 & 0 & 0 & 0 \\
10 & 0 & 90 & 0 & 0 & 0 \\
2 & 0 & 98 & 0 & 0 & 0 \\
5 & 3 & 92 & 0 & 0 & 0 \\
\hline
\end{tabular}


Tabel B3.3

Percentage werkende schoolverlaters met een flexibele aanstelling

Opleidingsrichting

VMBO

Theoretische leerweg

Landbouw Gem Iw landbouw en nat.omgeving

Landbouw KB landbouw en nat.omgeving $\quad 55$

Landbouw BB landbouw en nat.omgeving $\quad 53$

$\begin{array}{ll}\text { Techniek KB bouwtechniek } & 64\end{array}$

$\begin{array}{ll}\text { Techniek KB voertuigentechniek } & 28\end{array}$

Techniek KB electrotechniek $\quad 50$

$\begin{array}{ll}\text { Techniek BB bouwtechniek } & 58\end{array}$

$\begin{array}{ll}\text { Techniek BB metaaltechniek } & 47\end{array}$

Techniek BB voertuigentechniek $\quad 33$

$\begin{array}{ll}\text { Economie KB handel en administratie } & 41\end{array}$

Economie BB consumptief $\quad 43$

Zorg en Welzijn KB verzorging $\quad 36$

BOL niveau $1 / 2$

AB Beveiliging

BB Motorvoertuigen

BB Informatietechniek $\quad 65$

BB Bedrijfsadministratie $\quad 59$

BB Beveiliging $\quad 45$

BB Secretarieel $\quad 50$

BB Detailhandel/ambulante handel $\quad 32$

BB Horeca, instellingskeuken en contractcatering $\quad 51$

BB Verpleging en verzorging $\quad 43$

BOL niveau $3 / 4$

ZB Plantenteelt

ZB Veehouderij

ZB Bloemschikken

ZBierverzorging en veterinaire ondersteuning $\quad 39$

ZB Paardenhouderij en paardensport $\quad 43$

ZB Groene ruimte $\quad 53$

ZB Scheepvaart $\quad 27$

ZB Toerisme, recreatie en reizen $\quad 51$

$Z B$ Verpleging en verzorging $\quad 25$

ZB Uiterlijke verzorging $\quad 47$

ZB Sociaal pedagogisch werk $\quad 38$

KF Plantenteelt $\quad 53$

$\begin{array}{ll}\text { KF Veehouderij } & 31\end{array}$

KF Bloemschikken $\quad 45$

$\begin{array}{ll}\text { KF Dierverzorging en veterinaire ondersteuning } & 49\end{array}$

KF Paardenhouderij en paardensport $\quad 24$

KF Groene ruimte $\quad 52$

$\begin{array}{ll}\text { KF Milieutoezicht } & 20\end{array}$

MKF Bouw $\quad 41$

MKF Grond-, water- en wegenbouw $\quad 54$

MKF Reclame, presentatie en communicatie $\quad 41$

MKF Operationele techniek $\quad 9$

$\begin{array}{ll}\text { MKF Werktuigbouwkunde } & 38\end{array}$

MKF Motorvoertuigen $\quad 44$

MKF Energie- en informatietechniek $\quad 36$

MKF Informatietechniek $\quad 51$

MKF Edelsmeden 24

MKF Graf. techn, communicatie, audiovisueel en multimedia $\quad 52$

MKF Laboratoriumtechniek $\quad 18$

MKF Scheepvaart $\quad 22$

MKF Transport en logistiek $\quad 29$

MKF Automatisering $\quad 59$

MKF Bedrijfsadministratief $\quad 52$ 
Tabel B3.3 (vervolg)

Percentage werkende schoolverlaters met een flexibele aanstelling

Opleidingsrichting

BOL niveau 3/4 (vervolg)

MKF Commercieel

MKF Secretarieel

MKF Detailhandel/ambulante handel

MKF Horeca, instellingskeuken en contractcatering

MKF Toerisme, recreatie en reizen

MKF Assistenten gezondheidszorg

MKF Facilitaire dienstverlening

MKF Sport en bewegen

MKF Verpleging en verzorging

MKF Sociaal-pedagogisch werk algemeen

MKF Sociaal-juridisch werk

$B B L$ niveau $1 / 2$

$A B$ Groene ruimte

$A B$ Horeca, instellingskeuken en contractcatering

BB Plantenteelt

BB Bloemschikken

BB Groene ruimte

BB Bouw

BB Motorvoertuigen

BB Installatie-, service- en onderhoudstechniek

BB Wegvervoer

BB Detailhandel/ambulante handel

BB Horeca, instellingskeuken en contractcatering

BB Facilitaire dienstverlening

BB Verpleging en verzorging

BBL niveau $3 / 4$

ZB Plantenteelt

ZB Bloemschikken

ZB Groene ruimte

ZB Motorvoertuigen

ZB Horeca, instellingskeuken en contractcatering

$Z B$ Verpleging en verzorging

ZB Sociaal-pedagogisch werk

MKF Detailhandel/ambulante handel

MKF Horeca, instellingskeuken en contractcatering

MKF Verpleging en verzorging

MKF Sociaal-pedagogisch werk

Zie toelichting bladzijde 25 
Tabel B3.4

Belangrijkste bedrijfsgroepen waarin schoolverlaters werkzaam zijn

VMBO Theoretische leerweg

Niet-gespec. detailh. in winkel

Gezondheidszorg

Restaurants/cafetaria's/snackbars ed

Ov. dienstverlening

Ov. gespec. detailh. in winkel

Overheidsdienst.

Bouwinstallatie

VMBO Landbouw Gem Iw landbouw en nat.omgeving

Welzijnszorg

Burgerl./utilit.;grond-/water-/wegenb. (excl. grondverz.)

Handel in/repar. auto's (1)

Ov. gespec. detailh. in winkel

Dienstverl. tbv landb. (excl. veterin.dienst.)

Grooth. landbouwprod./lev. dieren

Ov. gespec. grooth./grooth. met een alg. assort.

Gespec. detailh. voed.-/genotmid. in winkel

VMBO Landbouw KB landbouw en nat.omgeving

Ov. gespec. detailh. in winkel

Niet-gespec. detailh. in winkel

Ov. dienstverlening

Dienstverl. tbv landb. (excl. veterin.dienst.)

Handel in/repar. auto's (1)

VMBO Landbouw BB landbouw en nat.omgeving

Ov. gespec. detailh. in winkel

Dienstverl. tbv landb. (excl. veterin.dienst.)

Niet-gespec. detailh. in winkel

Burgerl./utilit.;grond-/water-/wegenb. (excl. grondverz.)

Ov. dienstverlening

VMBO Techniek KB bouwtechniek

Afwerken gebouwen

Vervaard meubels

Bouwnijverheid

Handel in/repar. auto's (1)

VMBO Techniek KB voertuigentechniek

Handel in/repar. auto's (1)

Vervoer over weg

Vervaard. mach.prod./toepas.mech.energ.(excl.motorvoert.ed)

Vervaard. landbouwmach./-werkt.

Bouwnijverheid

Bouwinstallatie

Ov. gespec. detailh. in winkel

Zeevaart

Binnenvaart

Laad-/los-/overslagactiv./opslag

\section{VMBO Techniek KB electrotechniek}

Bouwinstallatie

Vervaard. mach.prod./toepas.mech.energ.(excl.motorvoert.ed)

Niet-gespec. detailh. in winkel

Gespec. detailh. voed.-/genotmid. in winkel

Ov. gespec. detailh. in winkel

Restaurants/cafetaria's/snackbars ed

Beveiliging/opsporing

Overheidsdienst. 
VMBO Techniek BB bouwtechniek

Afwerken gebouwen

VMBO Techniek BB metaaltechniek

Bouwinstallatie

Vervaard. metalen constructiew./ramen/deuren/kozijnen

Handel in/repar. auto's (2)

Vervaard. prod. rubber

Oppervlaktebehandeling/ov. metaalbewerking

Vervaard. mach./appar.

Vervaard. landbouwmach./-werkt.

Bouwrijp maken terreinen

Burgerl./utilit.;grond-/water-/wegenb. (excl. grondverz.)

Handel in/repar. auto's (1)

Vervoer over weg

Zeevaart

VMBO Techniek BB voertuigentechniek

Handel in/repar. auto's (1)

Bouwinstallatie

Vervoer over weg

Verhuur machines/werkt.

Overheidsdienst.

VMBO Economie KB handel en administratie

Ov. gespec. detailh. in winkel

Niet-gespec. detailh. in winkel

Vervaard. meubels

Burgerl./utilit.;grond-/water-/wegenb. (excl. grondverz.)

Gespec. detailh. voed.-/genotmid. in winkel

Hotels/pensions/conferentie-oorden

Restaurants/cafetaria's/snackbars ed

Cafes ed

Laad-/los-/overslagactiv./opslag

Bedrijfs-/werkgev.-/beroepsorganisaties

VMBO Economie BB consumptief

Restaurants/cafetaria's/snackbars ed

Hotels/pensions/conferentie-oorden

Gespec. detailh. voed.-/genotmid. in winkel

Vervaard. ov. voedingsmid.

Ov. gespec. detailh. in winkel

Overheidsdienst.

VMBO Zorg en Welzijn KB verzorging

Welzijnszorg

Ov. gespec. detailh. in winkel

Detailh. farmac./med. art./parfum/cosmet. in winkel

Restaurants/cafetaria's/snackbars ed

BOL AB Beveiliging

Overheidsdienst.

Vervoer over weg

Post-/koeriersdiensten

Beveiliging/opsporing

Ov. gespec. detailh. in winkel 
Tabel B3.4 (vervolg)

Belangrijkste bedrijfsgroepen waarin schoolverlaters werkzaam zijn

BOL BB Motorvoertuigen

Handel in/repar. auto's (1)

Handel in/repar. auto's (2)

BOL BB Informatietechniek

Afwerken gebouwen

Looien/bewerken leer

Niet-gespec. detailh. in winkel

Ov. gespec. detailh. in winkel

10

Detailh. niet in winkel

Restaurants/cafetaria's/snackbars ed

Ontwikkelen, produceren en uitgeven van software; softwareco 10

Reklamebureaus ed

Secundair onderwijs en educatie

Welzijnszorg

BOL BB Bedrijfsadministratie

Niet-gespec. detailh. in winkel

Welzijnszorg

Ov. gespec. detailh. in winkel

Grooth. voedings-/genotmid.

Beveiliging/opsporing

Slachterijen/vleesverwerking

Vervoer over weg

Akker-/tuinbouw

Grooth. ov. consumentenart.

BOL BB Beveiliging

Overheidsdienst.

Welzijnszorg

Ov. gespec. detailh. in winkel

Beveiliging/opsporing

Restaurants/cafetaria's/snackbars ed

Gezondheidszorg

BOL BB Secretarieel

Niet-gespec. detailh. in winkel

Prod./distrib. elektriciteit/aardgas/stoom/warm water

Uitzendbur./uitleenbedr./arbeidsbemid./testen/werven/select.

Vervaard. papier-/kartonw.

Grooth. intermediaire goederen (excl. agrar.)/afval/schroot

Ov. gespec. detailh. in winkel

Restaurants/cafetaria's/snackbars ed

Geldscheppende financ. instell.

Openbaar bestuur

Gezondheidszorg

BOL BB Detailhandel/ambulante handel

Ov. gespec. detailh. in winkel

Niet-gespec. detailh. in winkel

Detailh. farmac./med. art./parfum/cosmet. in winkel

Vervaard. timmerw.

Grooth. ov. consumentenart.

BOL BB Horeca, instellingskeuken en contractcatering

Restaurants/cafetaria's/snackbars ed 
Tabel B3.4 (vervolg)

Belangrijkste bedrijfsgroepen waarin schoolverlaters werkzaam zijn

BOL BB Verpleging en verzorging

Welzijnszorg

Post-/koeriersdiensten

BOL ZB Plantenteelt

Dienstverl. tbv landb. (excl. veterin.dienst.)

41

Welzijnszorg

Akker-/tuinbouw

Bouwrijp maken terreinen

Grooth. landbouwprod./lev. dieren

Landb./jacht/dienstverl. tbv landb./jacht

Verhuur bouw-/sloopmachines met bedienend personeel

BOL ZB Veehouderij

Fokken/houden dieren

Dienstverl. tbv landb. (excl. veterin.dienst.)

Grooth. landbouwprod./lev. dieren

BOL ZB Bloemschikken

Ov. gespec. detailh. in winkel

BOL ZB Dierverzorging en veterinaire ondersteuning Ov. gespec. detailh. in winkel

Veterinaire diensten

Welzijnszorg

Niet-gespec. detailh. in winkel

Laad-/los-/overslagactiv./opslag

BOL ZB Paardenhouderij en paardensport

Sport

Ov. gespec. detailh. in winkel

Fokken/houden dieren

Hotels/pensions/conferentie-oorden

Niet-gespec. detailh. in winkel

Gespec. detailh. voed.-/genotmid. in winkel

Dienstverl. tbv landb. (excl. veterin.dienst.)

Veterinaire diensten

BOL ZB Groene ruimte

Dienstverl. tbv landb. (excl. veterin.dienst.)

Ov. gespec. detailh. in winkel

BOL ZB Scheepvaart

Binnenvaart

Bouwrijp maken terreinen

Vervoer over water

Zeevaart

Grooth. ov. consumentenart.

Visserij/kweken vis/schaaldieren

BOL ZB Toerisme, recreatie en reizen

Reisorgan./-bemid.;informatieverstrek. op gebied toerisme

BOL ZB Verpleging en verzorging 
Tabel B3.4 (vervolg)

Belangrijkste bedrijfsgroepen waarin schoolverlaters werkzaam zijn

\section{BOL ZB Uiterlijke verzorging}

Ov. dienstverlening

Detailh. farmac./med. art./parfum/cosmet. in winkel

Niet-gespec. detailh. in winkel

BOL ZB Sociaal pedagogisch werk

Welzijnszorg

Niet-gespec. detailh. in winkel

BOL KF Plantenteelt

Akker-/tuinbouw

Ov. gespec. detailh. in winkel

Natuurwet. speur-/ontwikkelingsw.

Uitzendbur./uitleenbedr./arbeidsbemid./testen/werven/select.

Grooth. landbouwprod./lev. dieren

BOL KF Veehouderij

Fokken/houden dieren

Dienstverl. tbv landb. (excl. veterin.dienst.)

BOL KF Bloemschikken

Ov. gespec. detailh. in winkel

Welzijnszorg

Grooth. landbouwprod./lev. dieren

Niet-gespec. detailh. in winkel

Reiniging gebouwen/transportmid. ed

BOL KF Dierverzorging en veterinaire ondersteuning

Veterinaire diensten

Ov. gespec. detailh. in winkel

Welzijnszorg

Gezondheidszorg

BOL KF Paardenhouderij en paardensport

Sport

Ov. gespec. detailh. in winkel

Fokken/houden dieren

Vervaard. diervoeder

Grooth. landbouwprod./lev. dieren

Niet-gespec. detailh. in winkel

Secundair onderwijs en educatie

Veterinaire diensten

BOL KF Groene ruimte

Dienstverl. tbv landb. (excl. veterin.dienst.)

Burgerl./utilit.;grond-/water-/wegenb. (excl. grondverz.)

Ov. gespec. detailh. in winkel

Akker-/tuinbouw

Niet-gespec. detailh. in winkel

BOL KF Milieutoezicht

Openbaar bestuur

Architecten-/ingenieurs-/ov. techn.ontw.-/teken-/adviesbur.

Vervaard. chem. prod.

Bouwrijp maken terreinen

Laad-/los-/overslagactiv./opslag 
Tabel B3.4 (vervolg)

Belangrijkste bedrijfsgroepen waarin schoolverlaters werkzaam zijn

BOL MKF Bouw

Burgerl./utilit.;grond-/water-/wegenb. (excl. grondverz.)

Ov. gespec. detailh. in winkel

Openbaar bestuur

Bouwinstallatie

Afwerken gebouwen

Restaurants/cafetaria's/snackbars ed

Architecten-/ingenieurs-/ov. techn.ontw.-/teken-/adviesbur.

BOL MKF Grond-, water- en wegenbouw

Burgerl./utilit.;grond-/water-/wegenb. (excl. grondverz.)

15

Openbaar bestuur

Bouwrijp maken terreinen

Restaurants/cafetaria's/snackbars ed

Architecten-/ingenieurs-/ov. techn.ontw.-/teken-/adviesbur.

Handel in/repar. auto's (2)

Laad-/los-/overslagactiv./opslag

BOL MKF Reclame, presentatie en communicatie

Reklamebureaus ed

BOL MKF Operationele techniek

Aardolieverw.

Vervaard. basischemicalien

Slachterijen/vleesverwerking

Vervaard. ov. prod. metaal (excl. mach./transportmid.)

Vervaard. mach.prod./toepas.mech.energ.(excl.motorvoert.ed)

Aardolie-/steenkoolverw. ind.;bewerking splijt-/kweekstof.

BOL MKF Werktuigbouwkunde

Vervaard. mach.prod./toepas.mech.energ.(excl.motorvoert.ed)

Bouwinstallatie

Overheidsdienst.

Vervaard. ov. mach./appar. voor specif. ind. activ.

BOL MKF Motorvoertuigen

Handel in/repar. auto's (1)

Vervaard. mach.prod./toepas.mech.energ.(excl.motorvoert.ed)

Handel in/repar. auto's (2)

Handel auto-onderd./-accessoir.

Grooth. mach.appar./toebehoren

Vervoer over weg

Telecommunicatie

Verhuur transportmid. (excl. personenauto's)

Sport

BOL MKF Energie- en informatietechniek

Bouwinstallatie

Vervaard. ov. chem. prod.

Vervaard. audio-/video-/telecom.-appar./-benodigdh.

Scheepsbouw/-reparatie

Grooth. ov. consumentenart.

Repar. tbv partic. (niet auto's/motorfiets.)

Verhuur ov. roerende goederen

Uitzendbur./uitleenbedr./arbeidsbemid./testen/werven/select.

Beveiliging/opsporing 
Tabel B3.4 (vervolg)

Belangrijkste bedrijfsgroepen waarin schoolverlaters werkzaam zijn

BOL MKF Informatietechniek

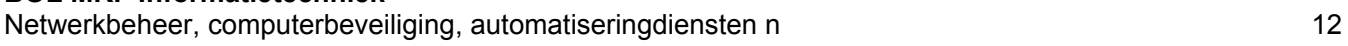

Telecommunicatie

Computerservice-/informatietechnologiebur. ed

Gezondheidszorg

Bouwinstallatie

Overheidsdienst.

Grooth. mach.appar./toebehoren

BOL MKF Edelsmeden

Ov. gespec. detailh. in winkel

Vervaard. sieraden ed (excl. imitatie-)

Repar. tbv partic. (niet auto's/motorfiets.)

Restaurants/cafetaria's/snackbars ed

BOL MKF Graf. techn, communicatie, audiovisueel en multimedia

Ov. gespec. detailh. in winkel

Reklamebureaus ed

Telecommunicatie

Verzekeringsw./pensioenfonds. (excl. verpl. soc.verzek.)

Radio/tv

Vervaard. papier-/kartonw.

Drukkerijen/aanverwante activ.

Vervaard. prod. beton/cement/gips

Computercentra en data-entry; webhosting

Exploitatie van databanken, zoekmachines, startpagina's, inf

Welzijnszorg

Sport

BOL MKF Laboratoriumtechniek

Gezondheidszorg

Openbaar bestuur

Natuurwet. speur-/ontwikkelingsw.

Dienstverl. tbv landb. (excl. veterin.dienst.)

Keuring/controle

BOL MKF Scheepvaart

Zeevaart

Scheepsbouw/-reparatie

Bouwrijp maken terreinen

Vervoer over water

Visserij/kweken vis/schaaldieren

Prod./distrib. elektriciteit/aardgas/stoom/warm water

Bouwinstallatie

Openbaar bestuur

BOL MKF Transport en logistiek

Laad-/los-/overslagactiv./opslag

Vervoer over water

Expedit./cargad./bevracht.;weging/meting

Restaurants/cafetaria's/snackbars ed

Handel in/repar. auto's (1)

Zeevaart

Vervoer over weg

BOL MKF Automatisering

Grooth. voedings-/genotmid.

Grooth. ov. consumentenart. 
BOL MKF Bedrijfsadministratief

Rechtsk. dienstverl./account./belastingconsul./holdings ed Handel in/repar. auto's (1)

Ov. gespec. detailh. in winkel

Overheidsdienst.

BOL MKF Commercieel

Geldscheppende financ. instell.

Verzekeringsw./pensioenfonds. (excl. verpl. soc.verzek.)

Rechtsk. dienstverl./account./belastingconsul./holdings ed

Activ. verzekeringsw./pensioenfonds.

Niet-gespec. detailh. in winkel

Telecommunicatie

BOL MKF Secretarieel

Rechtsk. dienstverl./account./belastingconsul./holdings ed

Gezondheidszorg

Burgerl./utilit.;grond-/water-/wegenb. (excl. grondverz.)

BOL MKF Detailhandel/ambulante handel

Ov. gespec. detailh. in winkel

Niet-gespec. detailh. in winkel

Grooth. ov. consumentenart.

Detailh. farmac./med. art./parfum/cosmet. in winkel

BOL MKF Horeca, instellingskeuken en contractcatering Hotels/pensions/conferentie-oorden

BOL MKF Toerisme, recreatie en reizen

Reisorgan./-bemid.;informatieverstrek. op gebied toerisme

Hotels/pensions/conferentie-oorden

Kampeerterreinen/ov. voorzien. recreat. verblijf n.e.g.

BOL MKF Assistenten gezondheidszorg

Gezondheidszorg

Detailh. farmac./med. art./parfum/cosmet. in winkel

BOL MKF Facilitaire dienstverlening

Kantines/catering

Welzijnszorg

Uitgeverijen

Kampeerterreinen/ov. voorzien. recreat. verblijf n.e.g.

Particuliere huishoudens met personeel in loondienst

Vervaard. glas/glaswerk

Ov. gespec. grooth./grooth. met een alg. assort.

Niet-gespec. detailh. in winkel

Gespec. detailh. voed.-/genotmid. in winkel

Sport

\section{BOL MKF Sport en bewegen}

Sport

Overheidsdienst.

Ov. dienstverlening

Primair onderwijs voor leerplichtingen en speciaal onderwijs

BOL MKF Verpleging en verzorging 
BOL MKF Sociaal-pedagogisch werk algemeen

Welzijnszorg

Primair onderwijs voor leerplichtingen en speciaal onderwijs

Gezondheidszorg

BOL MKF Sociaal-juridisch werk

Overheidsdienst.

Vervaard. ov. art. hout;vervaard. art. kurk/riet/vlechtw.

Prod./distrib. elektriciteit/aardgas/stoom/warm water

Niet-gespec. detailh. in winkel

Ov. gespec. detailh. in winkel

Verhuur onroerend goed

Openbaar bestuur

Verpl. soc. verzekeringen

Welzijnszorg

Cult. uitl.centra/openb. arch./musea/dieren-/plantentuin ed

Uitzendbur./uitleenbedr./arbeidsbemid./testen/werven/select.

\section{BBL AB Groene ruimte}

Vervaard. ov. goederen n.e.g.

Dienstverl. tbv landb. (excl. veterin.dienst.)

BBL AB Horeca, instellingskeuken en contractcatering

Restaurants/cafetaria's/snackbars ed

Vervaard. med. appar./instrum./orthop./prothese-art.

Handel in/repar. auto's (1)

Hotels/pensions/conferentie-oorden

$B B L A B$ Verpleging en verzorging

Welzijnszorg

BBL BB Plantenteelt

Akker-/tuinbouw

Dienstverl. tbv landb. (excl. veterin.dienst.)

BBL BB Bloemschikken

Ov. gespec. detailh. in winkel

BBL BB Groene ruimte

Dienstverl. tbv landb. (excl. veterin.dienst.)

Vervaard. ov. goederen n.e.g.

BBL BB Bouw

Burgerl./utilit.;grond-/water-/wegenb. (excl. grondverz.)

BBL BB Motorvoertuigen

Handel in/repar. auto's (1)

Vervaard. zendappar. tv/radio/appar. lijntelef./-telegr.

Handel in/repar. motorfiets./onderd./accessoir. daarv.

Ov. gespec. detailh. in winkel

Ov. dienstverl. tbv verv. n.e.g.

BBL BB Installatie-, service- en onderhoudstechniek 
Tabel B3.4 (vervolg)

Belangrijkste bedrijfsgroepen waarin schoolverlaters werkzaam zijn

BBL BB Wegvervoer

Vervoer over weg

Vervoer door lucht

Ov. gespec. grooth./grooth. met een alg. assort.

BBL BB Detailhandel/ambulante handel

Ov. gespec. detailh. in winkel

Niet-gespec. detailh. in winkel

Grooth. ov. consumentenart.

Vervoer over weg

Milieudienstverlening

BBL BB Horeca, instellingskeuken en contractcatering

Restaurants/cafetaria's/snackbars ed

Hotels/pensions/conferentie-oorden

Kantines/catering

BBL BB Facilitaire dienstverlening

Welzijnszorg

BBL BB Verpleging en verzorging

Welzijnszorg

Gezondheidszorg

BBL ZB Plantenteelt

Akker-/tuinbouw

Grooth. landbouwprod./lev. dieren

Dienstverl. tbv landb. (excl. veterin.dienst.)

Zand-/grind-/kleiwinning

Ov. gespec. detailh. in winkel

Dienstverl. tbv vervoer

Laad-/los-/overslagactiv./opslag

Ov. dienstverl. tbv verv. n.e.g.

BBL ZB Bloemschikken

Ov. gespec. detailh. in winkel

Akker-/tuinbouw

BBL ZB Groene ruimte

Dienstverl. tbv landb. (excl. veterin.dienst.)

BBL ZB Motorvoertuigen

Handel in/repar. auto's (1)

Sport

BBL ZB Horeca, instellingskeuken en contractcatering

Restaurants/cafetaria's/snackbars ed

Hotels/pensions/conferentie-oorden

Kantines/catering

Welzijnszorg

Gezondheidszorg

BBL ZB Sociaal-pedagogisch werk

Welzijnszorg

Primair onderwijs voor leerplichtingen en speciaal onderwijs 
Tabel B3.4 (vervolg)

Belangrijkste bedrijfsgroepen waarin schoolverlaters werkzaam zijn

BBL MKF Detailhandel/ambulante handel

Niet-gespec. detailh. in winkel

Ov. gespec. detailh. in winkel

Prod./distrib. elektriciteit/aardgas/stoom/warm water

Bouwinstallatie

Detailh. farmac./med. art./parfum/cosmet. in winkel

Welzijnszorg

BBL MKF Horeca, instellingskeuken en contractcatering

Restaurants/cafetaria's/snackbars ed

Cafes ed

12

Hotels/pensions/conferentie-oorden

Ov. gespec. detailh. in winkel

BBL MKF Verpleging en verzorging

Gezondheidszorg

Welzijnszorg

BBL MKF Sociaal-pedagogisch werk

Welzijnszorg

Gezondheidszorg

Zie toelichting bladzijde 30 
Tabel B3.5

Belangrijkste beroepsgroepen waarin schoolverlaters werkzaam zijn

VMBO Theoretische leerweg

Verkopers

Hulpkrachten horeca en verzorging

Aspirant politieagenten, soldaten en beveiligingshulpkrachten

Verpleeghulpen en leerling-verpleegkundigen

Verzorgend personeel

VMBO Landbouw Gem Iw landbouw en nat.omgeving

Productiemedewerker

Hulpkrachten horeca en verzorging

Assembleurs

Verzorgend personeel

Agrarische arbeider

Verkopers

Chauffeurs

VMBO Landbouw KB landbouw en nat.omgeving

Verkopers

Agrarische arbeider

Hulpkrachten horeca en verzorging

12

Landbouwmachinebestuurders en vissers

Monteurs

Laders en lossers

VMBO Landbouw BB landbouw en nat.omgeving

Verkopers

Agrarische arbeider

Hulpkrachten horeca en verzorging

Laders en lossers

VMBO Techniek KB bouwtechniek

Aannemers en installateurs

Assembleurs

VMBO Techniek KB voertuigentechniek

Monteurs

Chauffeurs

Laders en lossers

Metaalarbeiders

Assembleurs

Confectie-arbeiders

Elektromonteurs

VMBO Techniek KB electrotechniek

Elektromonteurs

Monteurs

Bouwvakkers

Elektronicamonteurs

Productiemedewerker

Monteurs en controleurs elektrotechnische producten

Mechanisch operators

Verkopers

Aspirant politieagenten, soldaten en beveiligingshulpkrachten

Hulpkrachten horeca en verzorging

VMBO Techniek BB bouwtechniek

Aannemers en installateurs 
Tabel B3.5 (vervolg)

Belangrijkste beroepsgroepen waarin schoolverlaters werkzaam zijn

VMBO Techniek BB metaaltechniek

Metaalarbeiders

Assembleurs

18

Monteurs

Agrarische hulparbeider

Aannemers en installateurs

Bouwvakkers

Chauffeurs

Bankwerkers en lassers

VMBO Techniek BB voertuigentechniek

Assembleurs

Bouwvakkers

Monteurs

Laders en lossers

VMBO Economie KB handel en administratie

Verkopers

Hulpkrachten horeca en verzorging

Bouwvakkers

Laders en lossers

Receptionisten en administratieve employés

Winkeliers

VMBO Economie BB consumptief

Bakkers en slagers

Hulpkrachten horeca en verzorging

Verzorgend personeel

Verkopers

VMBO Zorg en Welzijn KB verzorging

Hulpkrachten horeca en verzorging

Verzorgend personeel

Verkopers

Verpleeghulpen en leerling-verpleegkundigen

BOL AB Beveiliging

Aspirant politieagenten, soldaten en beveiligingshulpkrachten

Chauffeurs

Laders en lossers

Hulpkrachten horeca en verzorging

Politieagenten, onderofficieren en beveiligingsemployés

Vliegers, scheepskapiteins en leidinggevenden transport

BOL BB Motorvoertuigen

Monteurs

BOL BB Informatietechniek

Programmeurs

Laders en lossers

Mechanisch operators

Verkopers

Hulpkrachten horeca en verzorging

Hoofden technische dienst

Aannemers en installateurs 
Tabel B3.5 (vervolg)

Belangrijkste beroepsgroepen waarin schoolverlaters werkzaam zijn

BOL BB Bedrijfsadministratie

Receptionisten en administratieve employés $\quad 26$

Verkopers $\quad 18$

Boekhouders en secretaresses

Hulpkrachten horeca en verzorging

Aspirant politieagenten, soldaten en beveiligingshulpkrachten

Vakkenvuller

Agrarische arbeider

Productieplanners

BOL BB Beveiliging

Aspirant politieagenten, soldaten en beveiligingshulpkrachten $\quad 37$

Politieagenten, onderofficieren en beveiligingsemployés 10

BOL BB Secretarieel

Verkopers

Boekhouders en secretaresses

Receptionisten en administratieve employés

Activiteitenbegeleiders en medewerkers arbeidsbemiddeling

Productiemedewerker

Verplegenden en doktersassistenten

Commercieel employés

BOL BB Detailhandel/ambulante handel

Verkopers

Aannemers en installateurs

Winkeliers

Laders en lossers

BOL BB Horeca, instellingskeuken en contractcatering Hulpkrachten horeca en verzorging

Verzorgend personeel

Verkopers

BOL BB Verpleging en verzorging

Verzorgend personeel

Hulpkrachten horeca en verzorging

Verpleeghulpen en leerling-verpleegkundigen

Interieurverzorger

Chauffeurs

BOL ZB Plantenteelt

Landbouwmachinebestuurders en vissers 21

Monteurs

Agrarische arbeider

Interieurverzorger

Agrarische bedrijfshoofden

Weg- en waterbouwkundige vakkrachten

BOL ZB Veehouderij

Agrarische arbeider

Agrarische bedrijfshoofden

Weg- en waterbouwkundige arbeiders

Productiemedewerker

Laders en lossers

Agrarische vakkrachten 
Tabel B3.5 (vervolg)

Belangrijkste beroepsgroepen waarin schoolverlaters werkzaam zijn

BOL ZB Bloemschikken

Verkopers

Agrarische vakkrachten

BOL ZB Dierverzorging en veterinaire ondersteuning

Verkopers

Verplegenden en doktersassistenten

Hulpkrachten horeca en verzorging

Vakkenvuller

BOL ZB Paardenhouderij en paardensport

Verkopers

Agrarische arbeider

Agrarische bedrijfshoofden

Hulpkrachten horeca en verzorging

Interieurverzorger

Verplegenden en doktersassistenten

BOL ZB Groene ruimte

Agrarische arbeider

Agrarische bedrijfshoofden

Productiemedewerker

Productieplanners

Agrarische vakkrachten

Commercieel employés

BOL ZB Scheepvaart

Schippers en conducteurs $\quad 39$

Laders en lossers

Werktuigbouwkundig ontwerpers en hoofden technische dienst

Chauffeurs

BOL ZB Toerisme, recreatie en reizen

Commercieel employés

Receptionisten en administratieve employés

BOL ZB Verpleging en verzorging

Verzorgend personeel

Verpleeghulpen en leerling-verpleegkundigen

Verplegenden en doktersassistenten

Hulpkrachten horeca en verzorging

Ziekenverzorgenden

BOL ZB Uiterlijke verzorging

Verzorgend personeel

Ondersteunende administratieve hulpkrachten

BOL ZB Sociaal pedagogisch werk

Verzorgend personeel

Hulpkrachten horeca en verzorging

Activiteitenbegeleiders en medewerkers arbeidsbemiddeling 
Tabel B3.5 (vervolg)

Belangrijkste beroepsgroepen waarin schoolverlaters werkzaam zijn

BOL KF Plantenteelt

Agrarische arbeider

Agrarische vakkrachten

Agrarische bedrijfshoofden

13

Laders en lossers

Landbouwmachinebestuurders en vissers

11

Boekhouders en secretaresses

BOL KF Veehouderij

Agrarische bedrijfshoofden

Agrarische arbeider

Receptionisten en administratieve employés

Verkopers

Weg- en waterbouwkundige vakkrachten

BOL KF Bloemschikken

Agrarische vakkrachten

Agrarische arbeider

Hulpkrachten horeca en verzorging

Kunstenaars

BOL KF Dierverzorging en veterinaire ondersteuning

Verplegenden en doktersassistenten

Agrarische arbeider

Verkopers

Agrarische vakkrachten

Verzorgend personeel

Verpleeghulpen en leerling-verpleegkundigen

Receptionisten en administratieve employés

BOL KF Paardenhouderij en paardensport Agrarische arbeider

Sportinstructeurs

Verkopers

Chauffeurs

Receptionisten en administratieve employés

Agrarische vakkrachten

Verplegenden en doktersassistenten

Winkeliers

Docenten landbouw en techniek (2e en 3e gr.)

BOL KF Groene ruimte

Agrarische arbeider

Agrarische bedrijfshoofden

Agrarische vakkrachten

Verkopers

Weg- en waterbouwkundige vakkrachten

\section{BOL KF Milieutoezicht}

Milieuhygienisten en agrarisch vertegenwoordigers $\quad 42$

$\begin{array}{lr}\text { Weg- en waterbouwkundige arbeiders } & 18\end{array}$

Agrarische vakkrachten

Kantoorhulpen, inpakkers en colporteurs

Weg- en waterbouwkundige vakkrachten

Boekhouders en secretaresses

BOL MKF Bouw

Aannemers en installateurs 
Tabel B3.5 (vervolg)

Belangrijkste beroepsgroepen waarin schoolverlaters werkzaam zijn

BOL MKF Bouw (vervolg)

Verkopers

Confectie-arbeiders

Hulpkrachten horeca en verzorging

BOL MKF Grond-, water- en wegenbouw

Weg- en waterbouwkundige vakkrachten

Interieurverzorger

Weg- en waterbouwkundige arbeiders

Receptionisten en administratieve employés

Aannemers en installateurs

Procesoperators

Commercieel medewerkers

BOL MKF Reclame, presentatie en communicatie

Technisch-commercieel employés

Grafisch ontwerpers

Receptionisten en administratieve employés

Verkopers

Commercieel employés

BOL MKF Operationele techniek

Procesoperators

Assembleurs

Elektromonteurs

Monteurs

\section{BOL MKF Werktuigbouwkunde}

Monteurs

Aannemers en installateurs

Metaalarbeiders

Elektronicamonteurs

Productieplanners

We rktuigbouwkundig ontwerpers en hoofden technische dienst

\section{BOL MKF Motorvoertuigen}

Monteurs

Verkopers

Ondersteunende administratieve hulpkrachten

Assembleurs

Chauffeurs

Receptionisten en administratieve employés

Commercieel employés

Winkeliers

BOL MKF Energie- en informatietechniek

Elektromonteurs

Monteurs

Monteurs en controleurs elektrotechnische producten

Hoofden technische dienst

Elektronicamonteurs

Boekhouders en secretaresses

Technisch-commercieel employés

BOL MKF Informatietechniek

Programmeurs 
Tabel B3.5 (vervolg)

Belangrijkste beroepsgroepen waarin schoolverlaters werkzaam zijn

BOL MKF Informatietechniek (vervolg)

Monteurs en controleurs elektrotechnische producten

Technisch systeemanalisten

BOL MKF Edelsmeden

Bankwerkers en lassers

Ondersteunende administratieve hulpkrachten

Verkopers

Hulpkrachten horeca en verzorging

60

BOL MKF Graf. techn, communicatie, audiovisueel en multimedia

Grafisch ontwerpers

Receptionisten en administratieve employés

Verkopers

Boekhouders en secretaresses

Winkeliers

Journalisten

Ondersteunende administratieve hulpkrachten

Zweminstructeur

Elektromonteurs

Productieplanners

Programmeurs

Activiteitenbegeleiders en medewerkers arbeidsbemiddeling

BOL MKF Laboratoriumtechniek

Laboranten

Apothekersassistenten en medisch laboranten

Landbouwmachinebestuurders en vissers

BOL MKF Scheepvaart

Vliegers, scheepskapiteins en leidinggevenden transport 32

Monteurs

Weg- en waterbouwkundige vakkrachten

Schippers en conducteurs

Chauffeurs

Politie-inspecteurs en officieren

BOL MKF Transport en logistiek

Administratieve transportemployés

Laders en lossers

Productieplanners

Hulpkrachten horeca en verzorging

Receptionisten en administratieve employés

Politieagenten, onderofficieren en beveiligingsemployés

BOL MKF Automatisering

Programmeurs

Laders en lossers

Chauffeurs

Boekhouders en secretaresses

BOL MKF Bedrijfsadministratief

Boekhouders en secretaresses

Assistent accountants

Receptionisten en administratieve employés

20

Commercieel employés 
Tabel B3.5 (vervolg)

Belangrijkste beroepsgroepen waarin schoolverlaters werkzaam zijn

BOL MKF Commercieel

Commercieel employés

Receptionisten en administratieve employés

16

Verkopers

Boekhouders en secretaresses

Commercieel medewerkers

BOL MKF Secretarieel

Boekhouders en secretaresses

Receptionisten en administratieve employés

Verkopers

BOL MKF Detailhandel/ambulante handel

Verkopers

Winkeliers

Ondersteunende administratieve hulpkrachten

Boekhouders en secretaresses

Commercieel employés

Hulpkrachten horeca en verzorging

BOL MKF Horeca, instellingskeuken en contractcatering

Hulpkrachten horeca en verzorging

Verzorgend personeel

Receptionisten en administratieve employés

Boekhouders en secretaresses

Interieurverzorger

BOL MKF Toerisme, recreatie en reizen

Receptionisten en administratieve employés

Commercieel employés

Boekhouders en secretaresses

Verkopers

BOL MKF Assistenten gezondheidszorg

Verplegenden en doktersassistenten

Apothekersassistenten en medisch laboranten

BOL MKF Facilitaire dienstverlening

Hulpkrachten horeca en verzorging

Verzorgend personeel

Verkopers

Receptionisten en administratieve employés

Activiteitenbegeleiders en medewerkers arbeidsbemiddeling

Bedrijfshoofden horeca

Bankwerkers en lassers

Productieplanners

BOL MKF Sport en bewegen

Sportinstructeurs

Aspirant politieagenten, soldaten en beveiligingshulpkrachten Activiteitenbegeleiders en medewerkers arbeidsbemiddeling Verkopers

BOL MKF Verpleging en verzorging

Verplegenden en doktersassistenten 
Tabel B3.5 (vervolg)

Belangrijkste beroepsgroepen waarin schoolverlaters werkzaam zijn

BOL MKF Sociaal-pedagogisch werk algemeen

Verzorgend personeel

Activiteitenbegeleiders en medewerkers arbeidsbemiddeling

Verkopers

Hulpkrachten horeca en verzorging

Bankwerkers en lassers

BOL MKF Sociaal-juridisch werk

Verzorgend personeel

Mechanisch operators

Receptionisten en administratieve employés

Verkopers

Productieplanners

Commercieel employés

Politieagenten, onderofficieren en beveiligingsemployés

Bibliotheekassistenten

Assistent accountants

Aspirant politieagenten, soldaten en beveiligingshulpkrachten

Activiteitenbegeleiders en medewerkers arbeidsbemiddeling

BBL AB Groene ruimte

Agrarische arbeider

BBL AB Horeca, instellingskeuken en contractcatering

Hulpkrachten horeca en verzorging

Interieurverzorger

Verzorgend personeel

Apothekersassistenten en medisch laboranten

BBL AB Verpleging en verzorging

Hulpkrachten horeca en verzorging

BBL BB Plantenteelt

Agrarische arbeider

Landbouwmachinebestuurders en vissers

BBL BB Bloemschikken

Verkopers

Agrarische vakkrachten

Agrarische arbeider

Interieurverzorger

BBL BB Groene ruimte

Agrarische arbeider

BBL BB Bouw

Aannemers en installateurs

Bouwvakkers

BBL BB Motorvoertuigen

Monteurs

Assembleurs

17

Elektromonteurs

Winkeliers

Commercieel medewerkers 
Tabel B3.5 (vervolg)

Belangrijkste beroepsgroepen waarin schoolverlaters werkzaam zijn

BBL BB Installatie-, service- en onderhoudstechniek

Aannemers en installateurs

Bouwvakkers

BBL BB Wegvervoer

Chauffeurs

BBL BB Detailhandel/ambulante handel

Verkopers

Chauffeurs

Winkeliers

Ondersteunende administratieve hulpkrachten

Commercieel employés

BBL BB Horeca, instellingskeuken en contractcatering Hulpkrachten horeca en verzorging

BBL BB Facilitaire dienstverlening

Hulpkrachten horeca en verzorging

Verpleeghulpen en leerling-verpleegkundigen

BBL BB Verpleging en verzorging

Verzorgend personeel

Hulpkrachten horeca en verzorging

Ziekenverzorgenden

Verpleeghulpen en leerling-verpleegkundigen

BBL ZB Plantenteelt

Agrarische arbeider

Productieplanners

Landbouwmachinebestuurders en vissers

Commercieel employés

Concierges

Boekhouders en secretaresses

Agrarische bedrijfshoofden

BBL ZB Bloemschikken

Agrarische vakkrachten

Verkopers

Agrarische arbeider

BBL ZB Groene ruimte

Agrarische arbeider

BBL ZB Motorvoertuigen

Monteurs

BBL ZB Horeca, instellingskeuken en contractcatering

Verzorgend personeel

Hulpkrachten horeca en verzorging

BBL ZB Verpleging en verzorging

Verzorgend personeel

Ziekenverzorgenden

Hulpkrachten horeca en verzorging

BBL ZB Sociaal-pedagogisch werk

Verzorgend personeel

Therapeuten en verpleegkundigen 
Tabel B3.5 (vervolg)

Belangrijkste beroepsgroepen waarin schoolverlaters werkzaam zijn

BBL ZB Sociaal-pedagogisch werk (vervolg)

Bankwerkers en lassers

Hulpkrachten horeca en verzorging

BBL MKF Detailhandel/ambulante handel

Winkeliers

Verkopers

Chauffeurs

Receptionisten en administratieve employés

Activiteitenbegeleiders en medewerkers arbeidsbemiddeling

BBL MKF Horeca, instellingskeuken en contractcatering Hulpkrachten horeca en verzorging

Verzorgend personeel

Bedrijfshoofden horeca

Interieurverzorger

Receptionisten en administratieve employés

Verkopers

14

13

8

BBL MKF Verpleging en verzorging

Verplegenden en doktersassistenten

BBL MKF Sociaal-pedagogisch werk

Verzorgend personeel

Verplegenden en doktersassistenten

Activiteitenbegeleiders en medewerkers arbeidsbemiddeling

Therapeuten en verpleegkundigen

Zie ook toelichting bladzijde 35 
Tabel B3.6

Grootte van de organisatie waarin schoolverlaters werkzaam zijn

\begin{tabular}{|c|c|c|c|c|}
\hline Opleidingsrichting & $\begin{array}{r}1 \text { pers } \\
\%\end{array}$ & $\begin{array}{r}2 \mathrm{t} / \mathrm{m} 9 \\
\text { pers } \\
\%\end{array}$ & $\begin{array}{r}10 \mathrm{t} / \mathrm{m} \\
49 \text { pers } \\
\%\end{array}$ & $\begin{array}{r}50 \mathrm{t} / \mathrm{m} \\
99 \text { pers } \\
\%\end{array}$ \\
\hline
\end{tabular}

VMBO

Theoretische leerweg

Landbouw Gem Iw landbouw en nat.omgeving

Landbouw KB landbouw en nat.omgeving

Landbouw BB landbouw en nat.omgeving

Techniek KB bouwtechniek

Techniek KB voertuigentechniek

Techniek KB electrotechniek

Techniek BB bouwtechniek

Techniek BB metaaltechniek

Techniek BB voertuigentechniek

Economie $\mathrm{KB}$ handel en administratie

Economie BB consumptief

Zorg en Welzijn KB verzorging

BOL niveau 1/2

$A B$ Beveiliging

BB Motorvoertuigen

BB Informatietechniek

BB Bedrijfsadministratie

BB Beveiliging

BB Secretarieel

BB Detailhandel/ambulante handel

BB Horeca, instellingskeuken en contractcatering

$B B$ Verpleging en verzorging

$\begin{array}{rrrrr}0 & 23 & 29 & 7 & 41 \\ 0 & 20 & 40 & 14 & 27 \\ 1 & 35 & 33 & 5 & 26 \\ 2 & 28 & 35 & 7 & 27 \\ 4 & 28 & 52 & 0 & 16 \\ 0 & 33 & 28 & 11 & 28 \\ 0 & 19 & 37 & 6 & 37 \\ 3 & 31 & 34 & 11 & 20 \\ 0 & 47 & 18 & 12 & 24 \\ 0 & 37 & 37 & 7 & 19 \\ 0 & 29 & 53 & 6 & 12 \\ 0 & 35 & 25 & 4 & 36 \\ 7 & 14 & 7 & 7 & 64\end{array}$

BOL niveau $3 / 4$

ZB Plantenteelt

ZB Veehouderij

ZB Bloemschikken

ZB Dierverzorging en veterinaire ondersteuning

ZB Paardenhouderij en paardensport

ZB Groene ruimte

ZB Scheepvaart

ZB Toerisme, recreatie en reizen

$Z B$ Verpleging en verzorging

ZB Uiterlijke verzorging

ZB Sociaal pedagogisch werk

KF Plantenteelt

KF Veehouderij

KF Bloemschikken

KF Dierverzorging en veterinaire ondersteuning

KF Paardenhouderij en paardensport

KF Groene ruimte

KF Milieutoezicht

MKF Bouw

MKF Grond-, water- en wegenbouw

MKF Reclame, presentatie en communicatie

MKF Operationele techniek

MKF Werktuigbouwkunde

MKF Motorvoertuigen

MKF Energie- en informatietechniek

MKF Informatietechniek

MKF Edelsmeden

MKF Graf. techn, communicatie, audiovisueel en multimedia

MKF Laboratoriumtechniek

MKF Scheepvaart

MKF Transport en logistiek

$\begin{array}{rrrr}19 & 5 & 14 & 62 \\ 45 & 27 & 4 & 24 \\ 19 & 19 & 19 & 42 \\ 6 & 35 & 13 & 46 \\ 8 & 13 & 11 & 67 \\ 16 & 33 & 26 & 26 \\ 41 & 9 & 3 & 47 \\ 20 & 48 & 11 & 20 \\ 2 & 13 & 3 & 80\end{array}$


Tabel B3.6 (vervolg)

Grootte van de organisatie waarin schoolverlaters werkzaam zijn

\begin{tabular}{|c|c|c|c|c|c|}
\hline Opleidingsrichting & $\begin{array}{r}1 \text { pers } \\
\%\end{array}$ & $\begin{array}{r}2 \mathrm{t} / \mathrm{m} 9 \\
\text { pers } \\
\%\end{array}$ & $\begin{array}{r}10 \mathrm{t} / \mathrm{m} \\
49 \text { pers } \\
\%\end{array}$ & $\begin{array}{r}50 \mathrm{t} / \mathrm{m} \\
99 \mathrm{pers} \\
\%\end{array}$ & $\begin{array}{r}\geq 100 \\
\text { pers } \\
\%\end{array}$ \\
\hline
\end{tabular}

BOL niveau 3/4 (vervolg)

MKF Automatisering

MKF Bedrijfsadministratief

MKF Commercieel

MKF Secretarieel

MKF Detailhandel/ambulante handel

MKF Horeca, instellingskeuken en contractcatering

MKF Toerisme, recreatie en reizen

MKF Assistenten gezondheidszorg

MKF Facilitaire dienstverlening

MKF Sport en bewegen

MKF Verpleging en verzorging

MKF Sociaal-pedagogisch werk algemeen

MKF Sociaal-juridisch werk

$\begin{array}{rrrrr}0 & 4 & 39 & 4 & 52 \\ 0 & 18 & 30 & 7 & 44 \\ 2 & 20 & 25 & 5 & 48 \\ 0 & 8 & 31 & 16 & 45 \\ 1 & 22 & 32 & 14 & 30 \\ 0 & 17 & 33 & 9 & 41 \\ 0 & 17 & 32 & 16 & 34 \\ 0 & 33 & 46 & 3 & 18 \\ 0 & 0 & 37 & 7 & 56 \\ 0 & 5 & 45 & 10 & 40 \\ 0 & 0 & 3 & 4 & 93 \\ 0 & 8 & 23 & 5 & 63 \\ 0 & 0 & 19 & 28 & 53\end{array}$

BBL niveau $1 / 2$

$A B$ Groene ruimte

$A B$ Horeca, instellingskeuken en contractcatering

$A B$ Verpleging en verzorging

BB Plantenteelt

BB Bloemschikken

BB Groene ruimte

BB Bouw

BB Motorvoertuigen

BB Installatie-, service- en onderhoudstechniek

BB Wegvervoer

BB Detailhandel/ambulante handel

BB Horeca, instellingskeuken en contractcatering

BB Facilitaire dienstverlening

$B B$ Verpleging en verzorging

$\begin{array}{rrrrr}0 & 13 & 10 & 4 & 73 \\ 0 & 18 & 37 & 8 & 37 \\ 0 & 0 & 4 & 0 & 96 \\ 0 & 34 & 54 & 4 & 8 \\ 2 & 63 & 19 & 13 & 4 \\ 2 & 33 & 22 & 8 & 36 \\ 0 & 16 & 24 & 16 & 44 \\ 0 & 33 & 33 & 25 & 8 \\ 0 & 21 & 42 & 16 & 21 \\ 0 & 26 & 25 & 30 & 18 \\ 0 & 21 & 29 & 21 & 29 \\ 0 & 28 & 43 & 5 & 24 \\ 0 & 0 & 0 & 0 & 100 \\ 0 & 0 & 10 & 11 & 79\end{array}$

BBL niveau $3 / 4$

ZB Plantenteelt

ZB Bloemschikken

ZB Groene ruimte

ZB Motorvoertuigen

ZB Horeca, instellingskeuken en contractcatering

ZB Verpleging en verzorging

ZB Sociaal-pedagogisch werk

MKF Detailhandel/ambulante handel

MKF Horeca, instellingskeuken en contractcatering

MKF Verpleging en verzorging

MKF Sociaal-pedagogisch werk

$\begin{array}{rrrrr}0 & 36 & 27 & 5 & 33 \\ 0 & 61 & 30 & 6 & 3 \\ 2 & 33 & 22 & 5 & 38 \\ 0 & 36 & 36 & 9 & 18 \\ 0 & 30 & 40 & 11 & 19 \\ 0 & 0 & 4 & 17 & 78 \\ 0 & 0 & 40 & 6 & 54 \\ 0 & 25 & 25 & 17 & 33 \\ 0 & 25 & 41 & 27 & 7 \\ 0 & 2 & 0 & 1 & 97 \\ 0 & 5 & 0 & 13 & 81\end{array}$

Zie ook toelichting bladzijde 37 
Tabel B3.7

Beloning van werkende schoolverlaters

Opleidingsrichting

gemiddeld bruto

gemiddeld bruto

maandloon

uurloon

VMBO

Theoretische leerweg

4,44

Landbouw Gem Iw landbouw en nat.omgeving

592

Landbouw KB landbouw en nat.omgeving

$634-2-5$

Landbouw BB landbouw en nat.omgeving

4,36

Techniek KB bouwtechniek

$\begin{array}{ll}599 & 4,24 \\ 725 & 4,92\end{array}$

Techniek KB voertuigentechniek

4,92

Techniek KB electrotechniek

$\begin{array}{ll}728 & 4,52 \\ 618 & 4,00\end{array}$

Techniek BB bouwtechniek

Techniek BB metaaltechniek

4,92

Techniek BB voertuigentechniek

4,94
4,22

Economie KB handel en administratie

737

Economie BB consumptief

4,34

Zorg en Welzijn KB verzorging

BOL niveau 1/2

$A B$ Beveiliging

BB Motorvoertuigen

646

605

570

5,89

BB Informatietechniek

BB Bedrijfsadministratie

BB Beveiliging

BB Secretarieel

BB Detailhandel/ambulante handel

$016 \quad 6,51$

$890 \quad 5,63$

$1.389 \quad 9,18$

$868 \quad 5,72$

$1.151 \quad 7,50$

$1.030 \quad 6,73$

$874 \quad 6,00$

$948 \quad 8,05$

BOL niveau $3 / 4$

ZB Plantenteelt

ZB Veehouderij

1.007

6,79

ZB Bloemschikken

$Z B$ Dierverzorging en veterinaire ondersteuning

817

5,50

ZB Paardenhouderij en paardensport

784

5,44

ZB Groene ruimte

952

ZB Scheepvaart

5,78

$\begin{array}{ll}1.261 & 7,74\end{array}$

$1.984 \quad 11,14$

$Z B$ Toerisme, recreatie en reizen

$Z B$ Verpleging en verzorging

1.124

7,30

ZB Uiterlijke verzorging

ZB Sociaal pedagogisch werk

1.175

9,18

KF Plantenteelt

KF Veehouderij

KF Bloemschikken

KF Dierverzorging en veterinaire ondersteuning

$812 \quad 6,92$

$956 \quad 8,25$

$1.338 \quad 7,69$

$1.289 \quad 8,12$

$940 \quad 6,71$

$943 \quad 7,01$

$934 \quad 6,43$

$1.461 \quad 9,11$

KF Groene ruimte

9,68

KF Milieutoezicht

1.511

$1.436 \quad 8,70$

MKF Grond-, water- en wegenbouw

9,08

MKF Reclame, presentatie en communicatie

1.485

$\begin{array}{rr}1.485 & 9,08 \\ 1.265 & 8,08 \\ 2.041 & 12,96\end{array}$

MKF Operationele techniek

MKF Werktuigbouwkunde

MKF Motorvoertuigen

$1.578 \quad 9,46$

$\begin{array}{lrr}\text { MKF Energie- en informatietechniek } & 1.401 & 8,17 \\ \text { MKF Informatietechniek } & 1.420 & 8,61\end{array}$

MKF Edelsmeden

MKF Graf. techn, communicatie, audiovisueel en multimedia $\quad 1.276 \quad 8,62$

$\begin{array}{lll}\text { MKF Laboratoriumtechniek } & 1.521 & 9,62\end{array}$

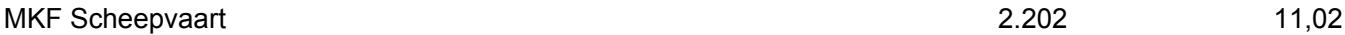

$\begin{array}{lrr}\text { MKF Transport en logistiek } & 1.365 & 8,40\end{array}$ 
Tabel B3. 7 (vervolg)

Beloning van werkende schoolverlaters

Opleidingsrichting

gemiddeld bruto

gemiddeld bruto

maandloon

uurloon

MKF Automatisering

MKF Bedrijfsadministratief

8,02
7,56

MKF Commercieel

$(.413$

MKF Secretarieel

7,82

MKF Detailhandel/ambulante handel

7,46

MKF Horeca, instellingskeuken en contractcatering

1.216

1.211

1.043

8,80

MKF Toerisme, recreatie en reizen

1.410

7,90

MKF Assistenten gezondheidszorg

1.239

8,90

MKF Facilitaire dienstverlening

1.283

7,25

MKF Sport en bewegen

MKF Verpleging en verzorging

MKF Sociaal-pedagogisch werk algemeen

1.340

9,64

$1.505 \quad 10,54$

MKF Sociaal-juridisch werk

BBL niveau $1 / 2$

AB Groene ruimte

$A B$ Horeca, instellingskeuken en contractcatering

1.085

9,81

$A B$ Verpleging en verzorging

BB Plantenteelt

BB Bloemschikken

BB Groene ruimte

BB Bouw

BB Motorvoertuigen

BB Installatie-, service- en onderhoudstechniek

BB Wegvervoer

BB Detailhandel/ambulante handel

BB Horeca, instellingskeuken en contractcatering

BB Facilitaire dienstverlening

1.331

8,67

1.312

1.041
654

$1.136 \quad 7,19$

$804 \quad 5,74$

$1.303 \quad 8,33$

$1.513 \quad 9,08$

$1.281 \quad 10,25$

$1.279-7,58$

$1.442 \quad 8,23$

$818 \quad 8,05$

$1.102 \quad 7,19$

$1.395 \quad 11,72$

$1.192 \quad 10,73$

BBL niveau $3 / 4$

ZB Plantenteelt

1.592

ZB Bloemschikken

1.180

7,64

ZB Groene ruimte

1.581

10,03

ZB Motorvoertuigen

$1.694 \quad 10,12$

ZB Horeca, instellingskeuken en contractcatering

$1.546 \quad 9,47$

ZB Verpleging en verzorging

$1.377 \quad 11,78$

$1.372 \quad 12,50$

MKF Detailhandel/ambulante handel

$1.151-7,82$

MKF Horeca, instellingskeuken en contractcatering

7,82

MKF Verpleging en verzorging

1.236

7,95
14,29

MKF Sociaal-pedagogisch werk

1.437

12,28

Zie ook toelichting bladzijde 39 
Tabel B3.8

Vereist opleidingsniveau voor de huidige functie volgens de werkgever

\begin{tabular}{lrrr}
\hline Opleidingsrichting & $\begin{array}{r}\text { lager } \\
\%\end{array}$ & $\begin{array}{r}\text { zelfde } \\
\%\end{array}$ & $\begin{array}{r}\text { hoger } \\
\%\end{array}$ \\
& & & \\
VMBO & & 56 & 32 \\
Theoretische leerweg & 12 & 70 & 31 \\
Landbouw Gem Iw landbouw en nat.omgeving & 5 & 56 & 46 \\
Landbouw KB landbouw en nat.omgeving & 13 & 39 & 40 \\
Landbouw BB landbouw en nat.omgeving & 15 & 48 & 29 \\
Techniek KB bouwtechniek & 12 & 59 & 41 \\
Techniek KB voertuigentechniek & 12 & 75 & 25 \\
Techniek KB electrotechniek & & 50 & 38 \\
Techniek BB bouwtechniek & 9 & 56 & 24 \\
Techniek BB metaaltechniek & 19 & 50 & 48 \\
Techniek BB voertuigentechniek & 12 & 53 & 38 \\
Economie KB handel en administratie & 24 & 42 & 62 \\
Economie BB consumptief & 10 & & \\
Zorg en Welzijn KB verzorging & & &
\end{tabular}

BOL niveau $1 / 2$

AB Beveiliging

BB Motorvoertuigen

BB Informatietechniek

BB Bedrijfsadministratie

BB Beveiliging

BB Secretarieel

BB Detailhandel/ambulante handel

BB Horeca, instellingskeuken en contractcatering

$B B$ Verpleging en verzorging

BOL niveau $3 / 4$

ZB Plantenteelt

ZB Veehouderij

ZB Bloemschikken

ZB Dierverzorging en veterinaire ondersteuning

ZB Paardenhouderij en paardensport

ZB Groene ruimte

ZB Scheepvaart

ZB Toerisme, recreatie en reizen

$Z B$ Verpleging en verzorging

ZB Uiterlijke verzorging

ZB Sociaal pedagogisch werk

KF Plantenteelt

KF Veehouderij

KF Bloemschikken

KF Dierverzorging en veterinaire ondersteuning

KF Paardenhouderij en paardensport

KF Groene ruimte

KF Milieutoezicht

MKF Bouw

MKF Grond-, water- en wegenbouw

MKF Reclame, presentatie en communicatie

MKF Operationele techniek

MKF Werktuigbouwkunde

MKF Motorvoertuigen

MKF Energie- en informatietechniek

MKF Informatietechniek

MKF Edelsmeden

MKF Graf. techn, communicatie, audiovisueel en multimedia

MKF Laboratoriumtechniek

MKF Scheepvaart

MKF Transport en logistiek 
Tabel B3.8 (vervolg)

Vereist opleidingsniveau voor de huidige functie volgens de werkgever

\begin{tabular}{|c|c|c|c|}
\hline Opleidingsrichting & $\begin{array}{r}\text { lager } \\
\%\end{array}$ & $\begin{array}{r}\text { zelfde } \\
\%\end{array}$ & $\begin{array}{r}\text { hoger } \\
\%\end{array}$ \\
\hline
\end{tabular}

BOL niveau $3 / 4$ (vervolg)

MKF Bedrijfsadministratief

MKF Commercieel

MKF Secretarieel

MKF Detailhandel/ambulante handel

MKF Horeca, instellingskeuken en contractcatering

MKF Toerisme, recreatie en reizen

MKF Assistenten gezondheidszorg

MKF Facilitaire dienstverlening

MKF Sport en bewegen

MKF Verpleging en verzorging

MKF Sociaal-pedagogisch werk algemeen

MKF Sociaal-juridisch werk

$\begin{array}{rrr}10 & 74 & 16 \\ 20 & 68 & 12 \\ 22 & 77 & 2 \\ 49 & 48 & 3 \\ 33 & 63 & 4 \\ 22 & 75 & 3 \\ 16 & 83 & 1 \\ 59 & 41 & 6 \\ 43 & 52 & 6 \\ 3 & 91 & 7 \\ 15 & 79 & 18 \\ 26 & 56 & \end{array}$

$B B L$ niveau $1 / 2$

$\mathrm{AB}$ Groene ruimte

$A B$ Horeca, instellingskeuken en contractcatering

$A B$ Verpleging en verzorging

BB Plantenteelt

BB Bloemschikken

BB Groene ruimte

BB Bouw

BB Motorvoertuigen

BB Installatie-, service- en onderhoudstechniek

BB Wegvervoer

BB Detailhandel/ambulante handel

BB Horeca, instellingskeuken en contractcatering

BB Facilitaire dienstverlening

BB Verpleging en verzorging

2

BBL niveau $3 / 4$

ZB Plantenteelt

ZB Bloemschikken

ZB Groene ruimte

ZB Motorvoertuigen

ZB Horeca, instellingskeuken en contractcatering

$Z B$ Verpleging en verzorging

ZB Sociaal-pedagogisch werk

MKF Detailhandel/ambulante handel

MKF Horeca, instellingskeuken en contractcatering

MKF Verpleging en verzorging

MKF Sociaal-pedagogisch werk

$\begin{array}{rrr}62 & 32 & 6 \\ 75 & 25 & \\ 84 & 16 & 9 \\ 55 & 36 & 9 \\ 47 & 44 & 26 \\ 48 & 26 & 22 \\ 43 & 35 & 18 \\ 36 & 46 & 16 \\ 42 & 42 & 7 \\ 57 & 36 & 21 \\ 71 & 7 & 45 \\ 26 & 30 & \\ 67 & 33 & 11 \\ 29 & 59 & \end{array}$

Zie ook toelichting bladzijde 41 
Tabel B3.9

Vereiste opleidingsrichting voor de huidige functie volgens de werkgever

\begin{tabular}{lrrr}
\hline Opleidingsrichting & $\begin{array}{r}\text { eigen/ } \\
\text { verwante } \\
\text { richting } \\
\%\end{array}$ & $\begin{array}{r}\text { andere } \\
\text { richting }\end{array}$ & $\begin{array}{r}\text { geen } \\
\text { richting }\end{array}$ \\
\hline
\end{tabular}

VMBO

Theoretische leerweg

$\begin{array}{rrr}63 & 3 & 34 \\ 49 & 19 & 32 \\ 55 & 3 & 42 \\ 61 & 3 & 36 \\ 80 & 4 & 16 \\ 67 & & 33 \\ 65 & & 35 \\ 75 & & 25 \\ 65 & & 35 \\ 70 & & 30 \\ 44 & 6 & 50 \\ 68 & 10 & 22 \\ 79 & & 21\end{array}$

andbouw Gem Iw landbouw en nat.omgeving

Landbouw KB landbouw en nat.omgeving

Landbouw BB landbouw en nat.omgeving

Techniek KB bouwtechniek

Techniek KB voertuigentechniek

Techniek KB electrotechniek

Techniek BB bouwtechniek

Techniek BB metaaltechniek

Techniek BB voertuigentechniek

Economie KB handel en administratie

Economie BB consumptief

Zorg en Welzijn KB verzorging

en

$\%$

BOL niveau $1 / 2$

AB Beveiliging

BB Motorvoertuigen

BB Informatietechniek

BB Bedrijfsadministratie

BB Beveiliging

BB Secretarieel

BB Detailhandel/ambulante handel

BB Horeca, instellingskeuken en contractcatering

BB Verpleging en verzorging

$\begin{array}{rrr}39 & 5 & 56 \\ 91 & 4 & 4 \\ 61 & 1 & 39 \\ 45 & & 55 \\ 35 & 10 & 55 \\ 24 & 9 & 66 \\ 61 & 11 & 28 \\ 78 & 2 & 20 \\ 82 & & 18\end{array}$

BOL niveau 3/4

ZB Plantenteelt

ZB Veehouderij

ZB Bloemschikken

ZB Dierverzorging en veterinaire ondersteuning

ZB Paardenhouderij en paardensport

ZB Groene ruimte

ZB Scheepvaart

ZB Toerisme, recreatie en reizen

ZB Verpleging en verzorging

ZB Uiterlijke verzorging

ZB Sociaal pedagogisch werk

KF Plantenteelt

KF Veehouderij

KF Bloemschikken

KF Dierverzorging en veterinaire ondersteuning

KF Paardenhouderij en paardensport

KF Groene ruimte

KF Milieutoezicht

MKF Bouw

MKF Grond-, water- en wegenbouw

MKF Reclame, presentatie en communicatie

MKF Operationele techniek

MKF Werktuigbouwkunde

MKF Motorvoertuigen

MKF Energie- en informatietechniek

MKF Informatietechniek

MKF Edelsmeden

MKF Graf. techn, communicatie, audiovisueel en multimedia

MKF Laboratoriumtechniek

MKF Scheepvaart

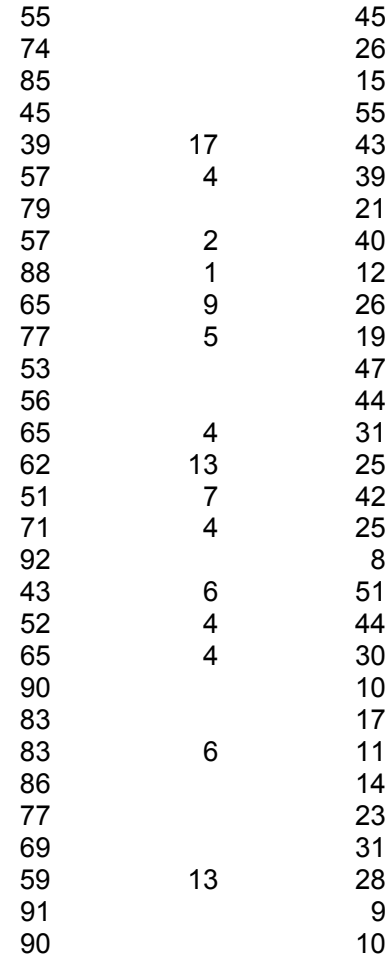


Tabel B3. 9 (vervolg)

Vereiste opleidingsrichting voor de huidige functie volgens de werkgever

\begin{tabular}{lrrr}
\hline Opleidingsrichting & $\begin{array}{r}\text { eigen/ } \\
\text { verwante } \\
\text { richting } \\
\%\end{array}$ & $\begin{array}{r}\text { andere } \\
\text { richting }\end{array}$ & $\begin{array}{r}\text { geen } \\
\text { richting }\end{array}$ \\
$\%$ & & $\%$ \\
\hline
\end{tabular}

BOL niveau 3/4 (vervolg)

MKF Transport en logistiek

MKF Automatisering

MKF Bedrijfsadministratief

MKF Commercieel

MKF Secretarieel

MKF Detailhandel/ambulante handel

MKF Horeca, instellingskeuken en contractcatering

MKF Toerisme, recreatie en reizen

MKF Assistenten gezondheidszorg

MKF Facilitaire dienstverlening

MKF Sport en bewegen

MKF Verpleging en verzorging

MKF Sociaal-pedagogisch werk algemeen

MKF Sociaal-juridisch werk

$\begin{array}{rrr}54 & 4 & 42 \\ 44 & 9 & 48 \\ 80 & 3 & 17 \\ 57 & 7 & 36 \\ 66 & 1 & 32 \\ 48 & 1 & 51 \\ 64 & 6 & 30 \\ 52 & 9 & 39 \\ 84 & 1 & 14 \\ 46 & 15 & 38 \\ 71 & 6 & 23 \\ 92 & & 8 \\ 79 & 2 & 18 \\ 59 & & 41\end{array}$

$B B L$ niveau $1 / 2$

AB Groene ruimte

$A B$ Horeca, instellingskeuken en contractcatering

$A B$ Verpleging en verzorging

BB Plantenteelt

BB Bloemschikken

BB Groene ruimte

BB Bouw

BB Motorvoertuigen

BB Installatie-, service- en onderhoudstechniek

BB Wegvervoer

BB Detailhandel/ambulante handel

BB Horeca, instellingskeuken en contractcatering

BB Facilitaire dienstverlening

BB Verpleging en verzorging

$\begin{array}{rrr}44 & 17 & 39 \\ 43 & 8 & 49 \\ 63 & 9 & 28 \\ 25 & 18 & 58 \\ 62 & 5 & 33 \\ 58 & 14 & 28 \\ 71 & 4 & 25 \\ 67 & 0 & 33 \\ 84 & & 16 \\ 70 & & 30 \\ 29 & & 71 \\ 75 & & 25 \\ 93 & & 7 \\ 80 & 3 & 16 \\ & & \\ & & \\ 51 & 10 & 39 \\ 67 & 15 & 18 \\ 66 & 18 & 16 \\ 82 & & 18 \\ 65 & 0 & 35 \\ 91 & 1 & 9 \\ 100 & & \\ 50 & 17 & 33 \\ 59 & 4 & 37 \\ 93 & 2 & 5 \\ 94 & & 6\end{array}$

BBL niveau 3/4

ZB Plantenteelt

ZB Bloemschikken

ZB Groene ruimte

ZB Motorvoertuigen

ZB Horeca, instellingskeuken en contractcatering

$Z B$ Verpleging en verzorging

ZB Sociaal-pedagogisch werk

MKF Detailhandel/ambulante handel

MKF Horeca, instellingskeuken en contractcatering

MKF Verpleging en verzorging

MKF Sociaal-pedagogisch werk

Zie ook toelichting bladzijde 43 
Tabel B3.10

Wekelijkse arbeidsduur van werkende schoolverlaters

Opleidingsrichting

wekelijkse

arbeidsduur

uren

\section{VMBO}

Theoretische leerweg

Landbouw Gem Iw landbouw en nat.omgeving

Landbouw KB landbouw en nat.omgeving $\quad 33,2$

Landbouw BB landbouw en nat.omgeving $\quad 32,0$

Techniek KB bouwtechniek $\quad 34,5$

\begin{tabular}{ll} 
Techniek KB voertuigentechniek & 34,5 \\
\hline
\end{tabular}

Techniek KB electrotechniek $\quad 35,7$

Techniek BB bouwtechniek $\quad 35,4$

Techniek BB metaaltechniek $\quad 35,6$

$\begin{array}{ll}\text { Techniek BB voertuigentechniek } & 35,6\end{array}$

Economie KB handel en administratie $\quad 32,8$

Economie BB consumptief 31,9

Zorg en Welzijn KB verzorging $\quad 32,9$

BOL niveau $1 / 2$

AB Beveiliging

BB Motorvoertuigen $\quad 36,7$

BB Informatietechniek $\quad 35,3$

BB Bedrijfsadministratie $\quad 35,2$

BB Beveiliging $\quad 35,6$

BB Secretarieel $\quad 35,1$

BB Detailhandel/ambulante handel $\quad 31,5$

BB Horeca, instellingskeuken en contractcatering $\quad 33,6$

$\begin{array}{lr}\text { BB Verpleging en verzorging } & 27,7\end{array}$

BOL niveau $3 / 4$

ZB Plantenteelt

ZB Veehouderij $\quad 41,0$

ZB Bloemschikken $\quad 33,6$

ZB Dierverzorging en veterinaire ondersteuning $\quad 31,4$

ZB Paardenhouderij en paardensport $\quad 34,2$

ZB Groene ruimte $\quad 38,3$

ZB Scheepvaart $\quad 43,3$

ZB Toerisme, recreatie en reizen $\quad 36,3$

ZB Verpleging en verzorging $\quad 29,8$

ZB Uiterlijke verzorging $\quad 28,3$

ZB Sociaal pedagogisch werk $\quad 26,8$

$\begin{array}{lr}\text { KF Plantenteelt } & 40,0\end{array}$

$\begin{array}{lr}\text { KF Veehouderij } & 38,2\end{array}$

KF Bloemschikken $\quad 33,1$

KF Dierverzorging en veterinaire ondersteuning $\quad 30,1$

KF Paardenhouderij en paardensport $\quad 35,8$

$\begin{array}{lr}\text { KF Groene ruimte } & 38,2\end{array}$

KF Milieutoezicht $\quad 36,2$

MKF Bouw $\quad 38,4$

MKF Grond-, water- en wegenbouw $\quad 37,9$

MKF Reclame, presentatie en communicatie $\quad 36,4$

MKF Operationele techniek $\quad 36,7$

$\begin{array}{lr}\text { MKF Werktuigbouwkunde } & 39,1\end{array}$

MKF Motorvoertuigen $\quad 38,2$

MKF Energie- en informatietechniek $\quad 39,5$

MKF Informatietechniek $\quad 37,5$

MKF Edelsmeden $\quad 34,6$

MKF Graf. techn, communicatie, audiovisueel en multimedia $\quad 34,1$

MKF Laboratoriumtechniek $\quad 36,8$

$\begin{array}{lr}\text { MKF Scheepvaart } & 48,8\end{array}$ 
Tabel B3.10 (vervolg)

Wekelijkse arbeidsduur van werkende schoolverlaters

Opleidingsrichting

wekelijkse

arbeidsduur

uren

BOL niveau 3/4 (vervolg)

MKF Transport en logistiek

MKF Automatisering

MKF Bedrijfsadministratief

MKF Commercieel

35,6

37,2

MKF Secretarieel

35,7

MKF Detailhandel/ambulante hande

MKF Horeca, instellingskeuken en contractcatering

37,1

MKF Toerisme, recreatie en reizen

36,4

MKF Assistenten gezondheidszorg $\quad 33,7$

MKF Facilitaire dienstverlening $\quad 29,6$

MKF Sport en bewegen $\quad 33,2$

MKF Verpleging en verzorging $\quad 32,9$

MKF Sociaal-pedagogisch werk algemeen $\quad 27,8$

MKF Sociaal-juridisch werk $\quad 31,4$

BBL niveau $1 / 2$

AB Groene ruimte

$A B$ Horeca, instellingskeuken en contractcatering $\quad 27,8$

$A B$ Verpleging en verzorging $\quad 17,4$

BB Plantenteelt $\quad 38,1$

BB Bloemschikken $\quad 32,8$

BB Groene ruimte $\quad 36,1$

BB Bouw $\quad 39,0$

BB Motorvoertuigen $\quad 38,6$

BB Installatie-, service- en onderhoudstechniek $\quad 38,9$

BB Wegvervoer $\quad 39,9$

BB Detailhandel/ambulante handel $\quad 33,8$

BB Horeca, instellingskeuken en contractcatering $\quad 35,1$

BB Facilitaire dienstverlening $\quad 27,4$

BB Verpleging en verzorging $\quad 26,2$

BBL niveau $3 / 4$

ZB Plantenteelt $\quad 38,6$

ZB Bloemschikken $\quad 35,2$

ZB Groene ruimte $\quad 36,8$

ZB Motorvoertuigen $\quad 38,5$

ZB Horeca, instellingskeuken en contractcatering

ZB Verpleging en verzorging $\quad 27,6$

ZB Sociaal-pedagogisch werk $\quad 26,8$

$\begin{array}{ll}\text { MKF Detailhandel/ambulante handel } & 33,2\end{array}$

MKF Horeca, instellingskeuken en contractcatering $\quad 36,3$

MKF Verpleging en verzorging $\quad 31,5$

$\begin{array}{lr}\text { MKF Sociaal-pedagogisch werk } & 26,9\end{array}$

Zie ook toelichting bladzijde 45 
Tabel B3.11

Oordeel van de werkende schoolverlaters over de aansluiting tussen de afgesloten opleiding en de huidige functie

\begin{tabular}{lrrrr}
\hline Opleidingsrichting & goed & $\begin{array}{r}\text { vol- } \\
\text { doende }\end{array}$ & matig & slech \\
& $\%$ & $\%$ & $\%$ & $\%$ \\
\hline
\end{tabular}

\section{VMBO}

Theoretische leerweg

Landbouw Gem Iw landbouw en nat.omgeving

Landbouw KB landbouw en nat.omgeving

Landbouw BB landbouw en nat.omgeving

Techniek KB bouwtechniek

Techniek KB voertuigentechniek

Techniek KB electrotechniek

Techniek BB bouwtechniek

Techniek BB metaaltechniek

Techniek BB voertuigentechniek

Economie KB handel en administratie

Economie BB consumptief

Zorg en Welzijn KB verzorging

$\begin{array}{rrrr}37 & 33 & 20 & 9 \\ 16 & 33 & 11 & 40 \\ 42 & 31 & 13 & 13 \\ 44 & 32 & 14 & 10 \\ 56 & 24 & 12 & 8 \\ 67 & 22 & & 11 \\ 41 & 35 & 12 & 12 \\ 71 & 17 & 9 & 3 \\ 29 & 53 & 12 & 6 \\ 74 & 7 & 15 & 4 \\ 40 & 40 & 13 & 7 \\ 53 & 34 & 9 & 4 \\ 77 & 8 & 8 & 8\end{array}$

BOL niveau $1 / 2$

$\mathrm{AB}$ Beveiliging

BB Motorvoertuigen

BB Informatietechniek

BB Bedriffsadministratie

BB Beveiliging

BB Secretarieel

BB Detailhandel/ambulante handel

BB Horeca, instellingskeuken en contractcatering

BB Verpleging en verzorging

$\begin{array}{rrrr}52 & 14 & 5 & 29 \\ 45 & 42 & 4 & 9 \\ 32 & 29 & 10 & 29 \\ 17 & 38 & 41 & 4 \\ 40 & 28 & 15 & 17 \\ 33 & 8 & 43 & 16 \\ 34 & 57 & 9 & \\ 57 & 35 & 6 & 1 \\ 53 & 27 & 7 & 12\end{array}$

BOL niveau $3 / 4$

ZB Plantenteelt

ZB Veehouderij

ZB Bloemschikken

ZB Dierverzorging en veterinaire ondersteuning

ZB Paardenhouderij en paardensport

ZB Groene ruimte

ZB Scheepvaart

ZB Toerisme, recreatie en reizen

ZB Verpleging en verzorging

ZB Uiterlijke verzorging

ZB Sociaal pedagogisch werk

KF Plantenteelt

KF Veehouderij

KF Bloemschikken

KF Dierverzorging en veterinaire ondersteuning

KF Paardenhouderij en paardensport

KF Groene ruimte

KF Milieutoezicht

MKF Bouw

MKF Grond-, water- en wegenbouw

MKF Reclame, presentatie en communicatie

MKF Operationele techniek

MKF Werktuigbouwkunde

MKF Motorvoertuigen

MKF Energie- en informatietechniek

MKF Informatietechniek

MKF Edelsmeden

MKF Graf. techn, communicatie, audiovisueel en multimedia

MKF Laboratoriumtechniek

MKF Scheepvaart

$\begin{array}{rrrr}40 & 32 & 12 & 16 \\ 38 & 48 & 9 & 6 \\ 50 & 38 & 3 & 9 \\ 17 & 38 & 21 & 24 \\ 42 & 7 & 25 & 25 \\ 41 & 43 & 14 & 3 \\ 49 & 27 & 12 & 12 \\ 25 & 35 & 27 & 12 \\ 58 & 31 & 8 & 3 \\ 43 & 37 & 11 & 9 \\ 49 & 32 & 9 & 10 \\ 40 & 42 & 18 & \\ 35 & 33 & 21 & 11 \\ 44 & 52 & 4 & \\ 28 & 52 & 10 & 10 \\ 48 & 37 & 7 & 9 \\ 40 & 47 & 7 & 6 \\ 24 & 61 & 8 & 8 \\ 34 & 52 & 7 & 6 \\ 28 & 35 & 4 & 33 \\ 46 & 37 & 12 & 4 \\ 54 & 43 & & 3 \\ 25 & 65 & 7 & 3 \\ 28 & 39 & 22 & 11 \\ 20 & 47 & 27 & 7 \\ 33 & 46 & 16 & 5 \\ 54 & 33 & 13 & \\ 35 & 13 & 28 & 24 \\ 48 & 52 & & \\ 34 & 63 & & 4\end{array}$


Tabel B3.11 (vervolg)

Oordeel van de werkende schoolverlaters over de aansluiting tussen de afgesloten opleiding en de huidige functie

\begin{tabular}{|c|c|c|c|c|}
\hline Opleidingsrichting & $\begin{array}{r}\text { goed } \\
\%\end{array}$ & $\begin{array}{r}\text { vol- } \\
\text { doende } \\
\%\end{array}$ & $\begin{array}{r}\text { matig } \\
\%\end{array}$ & $\begin{array}{r}\text { slecht } \\
\%\end{array}$ \\
\hline \multicolumn{5}{|l|}{ BOL niveau 3/4 (vervolg) } \\
\hline MKF Transport en logistiek & 34 & 36 & 14 & 16 \\
\hline MKF Automatisering & 4 & 44 & 30 & 22 \\
\hline MKF Bedrijfsadministratief & 41 & 45 & 12 & 2 \\
\hline MKF Commercieel & 22 & 47 & 20 & 12 \\
\hline MKF Secretarieel & 34 & 54 & 8 & 4 \\
\hline MKF Detailhandel/ambulante handel & 36 & 43 & 13 & 8 \\
\hline MKF Horeca, instellingskeuken en contractcatering & 49 & 35 & 14 & 2 \\
\hline MKF Toerisme, recreatie en reizen & 38 & 34 & 21 & 7 \\
\hline MKF Assistenten gezondheidszorg & 60 & 32 & 8 & \\
\hline MKF Facilitaire dienstverlening & 25 & 30 & 15 & 29 \\
\hline MKF Sport en bewegen & 53 & 30 & 8 & 10 \\
\hline MKF Verpleging en verzorging & 42 & 37 & 15 & 6 \\
\hline MKF Sociaal-pedagogisch werk algemeen & 39 & 42 & 13 & 6 \\
\hline MKF Sociaal-juridisch werk & 9 & 56 & 18 & 17 \\
\hline \multicolumn{5}{|l|}{ BBL niveau $1 / 2$} \\
\hline AB Groene ruimte & 69 & 26 & 3 & 1 \\
\hline AB Horeca, instellingskeuken en contractcatering & 50 & 21 & 21 & 8 \\
\hline$A B$ Verpleging en verzorging & 67 & 31 & 2 & \\
\hline BB Plantenteelt & 49 & 28 & 13 & 9 \\
\hline BB Bloemschikken & 69 & 22 & 5 & 5 \\
\hline BB Groene ruimte & 52 & 38 & 7 & 3 \\
\hline BB Bouw & 50 & 27 & 15 & 8 \\
\hline BB Motorvoertuigen & 17 & 42 & 25 & 17 \\
\hline BB Installatie-, service- en onderhoudstechniek & 68 & 26 & 5 & \\
\hline BB Wegvervoer & 64 & 29 & & 7 \\
\hline BB Detailhandel/ambulante handel & 36 & 43 & 21 & \\
\hline BB Horeca, instellingskeuken en contractcatering & 58 & 28 & 11 & 3 \\
\hline BB Facilitaire dienstverlening & 93 & 3 & & 3 \\
\hline BB Verpleging en verzorging & 84 & 7 & 6 & 3 \\
\hline \multicolumn{5}{|l|}{ BBL niveau $3 / 4$} \\
\hline ZB Plantenteelt & 40 & 53 & 7 & \\
\hline ZB Bloemschikken & 63 & 17 & 13 & 6 \\
\hline ZB Groene ruimte & 53 & 38 & 3 & 5 \\
\hline ZB Motorvoertuigen & 63 & 28 & 9 & \\
\hline ZB Horeca, instellingskeuken en contractcatering & 42 & 49 & 9 & 0 \\
\hline ZB Verpleging en verzorging & 74 & 25 & 1 & \\
\hline ZB Sociaal-pedagogisch werk & 59 & 25 & 14 & 2 \\
\hline MKF Detailhandel/ambulante handel & 18 & 27 & 45 & 9 \\
\hline MKF Horeca, instellingskeuken en contractcatering & 59 & 30 & 3 & 8 \\
\hline MKF Verpleging en verzorging & 47 & 40 & 10 & 2 \\
\hline MKF Sociaal-pedagogisch werk & 59 & 30 & 8 & 3 \\
\hline
\end{tabular}

Zie ook toelichting bladzijde 46 
Tabel B3.12

Percentage werkende schoolverlaters dat op zoek is naar een andere baan

Opleidingsrichting

VMBO

Theoretische leerweg

Landbouw KB landbouw en nat.omgeving

11

Landbouw BB landbouw en nat.omgeving

Techniek KB electrotechniek

Techniek BB bouwtechniek

Techniek BB metaaltechniek

Techniek BB voertuigentechniek

Economie $\mathrm{KB}$ handel en administratie

Economie BB consumptief

Zorg en Welzijn KB verzorging

BOL niveau $1 / 2$

$\mathrm{AB}$ Beveiliging

BB Motorvoertuigen

BB Informatietechniek

BB Bedrijfsadministratie

BB Beveiliging

BB Secretarieel

BB Detailhandel/ambulante handel

BB Horeca, instellingskeuken en contractcatering

BB Verpleging en verzorging

BOL niveau $3 / 4$

ZB Plantenteelt

ZB Bloemschikken

ZB Dierverzorging en veterinaire ondersteuning

ZB Paardenhouderij en paardensport

ZB Groene ruimte

ZB Scheepvaart

ZB Toerisme, recreatie en reizen

ZB Verpleging en verzorging

ZB Uiterlijke verzorging

ZB Sociaal pedagogisch werk

8

KF Plantenteelt

KF Veehouderij

KF Bloemschikken

KF Dierverzorging en veterinaire ondersteuning

KF Paardenhouderij en paardensport

KF Groene ruimte

KF Milieutoezicht

MKF Bouw

MKF Grond-, water- en wegenbouw

MKF Reclame, presentatie en communicatie

MKF Operationele techniek

MKF Motorvoertuigen

MKF Energie- en informatietechniek

MKF Informatietechniek

MKF Edelsmeden

MKF Graf. techn, communicatie, audiovisueel en multimedia

MKF Laboratoriumtechniek

MKF Scheepvaart

MKF Transport en logistiek

MKF Automatisering

MKF Bedrijfsadministratief

MKF Commercieel

MKF Secretarieel

MKF Detailhandel/ambulante hande

MKF Horeca, instellingskeuken en contractcatering

MKF Toerisme, recreatie en reizen 
Tabel B3.12 (vervolg)

Percentage werkende schoolverlaters dat op zoek is naar een andere baan

Opleidingsrichting

MKF Assistenten gezondheidszorg

MKF Facilitaire dienstverlening

MKF Sport en bewegen

MKF Verpleging en verzorging

MKF Sociaal-pedagogisch werk algemeen

MKF Sociaal-juridisch werk

BBL niveau $1 / 2$

$A B$ Groene ruimte

AB Horeca, instellingskeuken en contractcatering $\quad r$

$A B$ Verpleging en verzorging $\quad 8$

$\begin{array}{lr}\text { BB Plantenteelt } & 9\end{array}$

BB Bloemschikken $\quad 18$

BB Groene ruimte $\quad 15$

\begin{tabular}{lr} 
BB Bouw & 19 \\
\hline B & 17
\end{tabular}

BB Motorvoertuigen $\quad 17$

$\begin{array}{ll}\text { BB Wegvervoer } & 10\end{array}$

BB Horeca, instellingskeuken en contractcatering $\quad 24$

$\begin{array}{ll}\text { BB Facilitaire dienstverlening } & 7\end{array}$

$\begin{array}{ll}\text { BB Verpleging en verzorging } & 10\end{array}$

BBL niveau $3 / 4$

ZB Plantenteelt

6

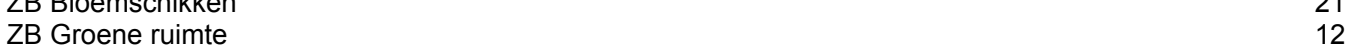

ZB Horeca, instellingskeuken en contractcatering 16

$\begin{array}{ll}Z B \text { Verpleging en verzorging } & 12\end{array}$

ZB Sociaal-pedagogisch werk $\quad 39$

MKF Detailhandel/ambulante handel $\quad 9$

MKF Horeca, instellingskeuken en contractcatering $\quad 35$

MKF Verpleging en verzorging $\quad 15$

$\begin{array}{ll}\text { MKF Sociaal-pedagogisch werk } & 14\end{array}$ 
Tabel B4.1

Enkele kernindicatoren

\begin{tabular}{|c|c|c|c|c|c|c|c|c|c|}
\hline \multirow[t]{2}{*}{ Opleidingsrichting } & \multirow[t]{2}{*}{$\begin{array}{r}\text { opgehoogd } \\
\text { aantal } \\
\text { populatie }\end{array}$} & \multirow{2}{*}{$\begin{array}{r}\text { verder } \\
\text { leren } \\
\\
\%\end{array}$} & \multirow{2}{*}{$\begin{array}{r}\text { zelfde } \\
\text { opleiding } \\
\text { opnieuw? } \\
\%\end{array}$} & \multirow{2}{*}{$\begin{array}{r}\begin{array}{r}\text { werk- } \\
\text { loos- } \\
\text { heid }\end{array} \\
\%\end{array}$} & \multirow{2}{*}{$\begin{array}{r}\text { intrede } \\
\text { werkloos- } \\
\text { heid } \\
\text { maanden }\end{array}$} & \multirow{2}{*}{$\begin{array}{r}\text { flexibele } \\
\text { aan- } \\
\text { stelling } \\
\%\end{array}$} & \multirow{2}{*}{$\begin{array}{r}\text { bruto } \\
\text { uurloon } \\
€\end{array}$} & \multirow{2}{*}{$\begin{array}{r}\text { minimaal } \\
\text { eigen } \\
\text { niveau } \\
\%\end{array}$} & \multirow{2}{*}{$\begin{array}{r}\text { eigen/ } \\
\text { verwante } \\
\text { richting } \\
\%\end{array}$} \\
\hline & & & & & & & & & \\
\hline \multicolumn{10}{|l|}{ VMBO } \\
\hline Theoretische leerweg & 38.143 & 19 & $\mathrm{x}$ & 12 & 0,5 & 45 & 4,44 & 88 & 34 \\
\hline Landbouw Gem Iw landbouw en nat.omgeving & 541 & 91 & $\mathrm{x}$ & 16 & 1,1 & 46 & 4,61 & 95 & 32 \\
\hline Landbouw KB landbouw en nat.omgeving & 2.156 & 88 & $\mathrm{x}$ & 8 & 0,6 & 55 & 4,36 & 87 & 42 \\
\hline Landbouw BB landbouw en nat.omgeving & 3.128 & 78 & $\mathrm{x}$ & 8 & 0,9 & 53 & 4,24 & 85 & 36 \\
\hline Techniek KB bouwtechniek & 1.348 & 95 & $\mathrm{x}$ & 0 & 0,0 & 64 & 4,92 & 88 & 16 \\
\hline Techniek KB voertuigentechniek & 887 & 87 & $\mathrm{x}$ & 5 & 0,2 & 28 & 4,52 & 88 & 33 \\
\hline Techniek KB electrotechniek & 1.728 & 90 & $\mathrm{x}$ & 0 & 1,2 & 50 & 4,00 & 100 & 35 \\
\hline Techniek KB overig & 60 & - & $x$ & 0 & 0,3 & - & - & - & - \\
\hline Techniek BB bouwtechniek & 3.583 & 90 & $x$ & 0 & 0,3 & 58 & 4,92 & 91 & 25 \\
\hline Techniek BB metaaltechniek & 2.038 & 68 & $\mathrm{x}$ & 6 & 0,3 & 47 & 4,94 & 81 & 35 \\
\hline Techniek BB voertuigentechniek & 1.602 & 77 & $x$ & 0 & 0,1 & 33 & 4,22 & 88 & 30 \\
\hline Techniek BB electrotechniek & 1.239 & 72 & $x$ & 10 & 0,1 & - & - & - & - \\
\hline Techniek BB overig & 88 & 95 & $\mathrm{x}$ & 0 & 0,1 & - & - & - & - \\
\hline Economie KB & 84 & 91 & $\mathrm{x}$ & 0 & 0,6 & - & - & - & - \\
\hline Economie $\mathrm{KB}$ administratie & 1.565 & 92 & $\mathrm{x}$ & 0 & 0,0 & - & - & - & - \\
\hline Economie KB handel en administratie & 2.759 & 82 & $\mathrm{x}$ & 6 & 0,4 & - & - & - & - \\
\hline Economie BB administratie & 2.109 & 76 & $\mathrm{x}$ & 14 & 0,2 & - & - & - & 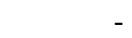 \\
\hline Economie BB handel en verkoop & 750 & - & $\mathrm{x}$ & 0 & 0,4 & - & - & - & - \\
\hline Economie BB handel en administratie & 899 & 91 & $\mathrm{x}$ & 14 & 0,4 & 41 & 4,34 & 77 & 50 \\
\hline Economie BB consumptief & 1.103 & 73 & $\mathrm{x}$ & 14 & 0,1 & 43 & 4,35 & 90 & 22 \\
\hline Zorg en Welzijn Gem lw zorg en welzijn-breed & 627 & 100 & $\mathrm{x}$ & 0 & 0,0 & - & - & - & - \\
\hline Zorg en Welzijn KB & 52 & 100 & $\mathrm{x}$ & - & - & - & - & - & 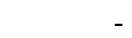 \\
\hline Zorg en Welzijn KB verzorging & 1.692 & 88 & $\mathrm{x}$ & 7 & 1,2 & 36 & 5,89 & 100 & 21 \\
\hline Zorg en Welzijn KB zorg en welzijn-breed & 2.088 & 97 & $\mathrm{x}$ & 0 & 0,6 & - & - & - & - \\
\hline Zorg en Welzijn BB verzorging & 2.364 & 87 & $\mathrm{x}$ & 0 & 0,3 & - & - & - & - \\
\hline Zorg en Welzijn BB zorg en welzijn-breed & 1.916 & 92 & $\mathrm{x}$ & 10 & 0,3 & - & - & - & - \\
\hline
\end{tabular}


Tabel B4. 1 (vervolg)

Enkele kernindicatoren

\begin{tabular}{|c|c|c|c|c|c|c|c|c|c|}
\hline \multirow[t]{2}{*}{ Opleidingsrichting } & $\begin{array}{r}\text { opgehoogd } \\
\text { aantal } \\
\text { populatie }\end{array}$ & $\begin{array}{c}\text { verder } \\
\text { leren }\end{array}$ & $\begin{array}{r}\text { zelfde } \\
\text { opleiding } \\
\text { opnieuw? }\end{array}$ & $\begin{array}{c}\text { werk- } \\
\text { loos- } \\
\text { heid }\end{array}$ & $\begin{array}{r}\text { intrede } \\
\text { werkloos- } \\
\text { heid }\end{array}$ & $\begin{array}{r}\text { flexibele } \\
\text { aan- } \\
\text { stelling }\end{array}$ & $\begin{array}{r}\text { bruto } \\
\text { uurloon }\end{array}$ & $\begin{array}{r}\text { minimaal } \\
\text { eigen } \\
\text { niveau }\end{array}$ & $\begin{array}{r}\text { eigen/ } \\
\text { verwante } \\
\text { richting }\end{array}$ \\
\hline & & $\%$ & $\%$ & $\%$ & maanden & $\%$ & $€$ & $\%$ & $\%$ \\
\hline
\end{tabular}

\section{BOL niveau 1/2}

$\mathrm{AB}$ Beveiliging

$A B$ Secretarieel

BB Bloemschikken

BB Dierverzorging en veterinaire ondersteuning

BB Motorvoertuigen

BB Informatietechniek

BB Scheepvaart

BB Bedrijfsadministratie

BB Beveiliging

BB Secretarieel

BB Detailhandel/ambulante handel

BB Horeca, instellingskeuken en contractcatering

1.542

1.189

50
81

379

1.091

117
1.132
514

1.132
514

820

820

1.094

BB Toerisme, recreatie en reizen

229
2.717

BOL niveau $3 / 4$

ZB Plantenteelt

ZB Veehouderij

ZB Dierverzorging en veterinaire ondersteuning

ZB Paardenhouderij en paardensport

ZB Groene ruimte

ZB Graf. techn, communicatie, audiovisueel en multimedia

ZB Scheepvaart

ZB Automatisering

ZB Bedrijfsadministratie

ZB Toerisme, recreatie en reizen

259

193
202

248

134

325

165

416

$\begin{array}{rl}- & 60 \\ - & 54 \\ - & 59 \\ - & 63 \\ 86 & 61 \\ 47 & 49 \\ - & 93 \\ - & 57 \\ 21 & 51 \\ - & 50 \\ 61 & 51 \\ 72 & 75 \\ - & 56 \\ 51 & 75 \\ & \\ & \\ 47 & 66 \\ - & 74 \\ 42 & 74 \\ 23 & 59 \\ - & 44 \\ 40 & 73 \\ - & 40 \\ - & 77 \\ - & 76 \\ - & 67 \\ 15 & 66\end{array}$

24
57
25
15
22
55
0
27
21
41
16
8
23
21


1
1
0
6
29
14
20
49
0
40
9
10

1,9
5,3
2,0
1,3
1,1
5,3
0,0
3,7
1,3
3,0
0,0
0,8
1,5
2,5

42

33

39

15

0,9
0,0
0,4
1,7
1,1
1,5
10,2
0,8
8,3
0,4
1,7

42

65

5,63

9,18

81

59

$\begin{array}{rrrr}31 & 6,79 & 43 & 55 \\ 37 & 5,50 & 42 & 74 \\ 37 & 5,44 & 45 & 85 \\ 39 & 5,99 & 17 & 45 \\ 43 & 5,78 & 39 & 39 \\ 53 & 7,74 & 45 & 57 \\ - & - & - & 79 \\ 27 & 11,14 & 38 & 57 \\ - & - & - & - \\ - & - & - & - \\ 51 & 7,30 & 60 & 88\end{array}$


Tabel B4. 1 (vervolg)

Enkele kernindicatoren

\begin{tabular}{|c|c|c|c|c|c|c|c|c|c|}
\hline \multirow[t]{2}{*}{ Opleidingsrichting } & $\begin{array}{r}\text { opgehoogd } \\
\text { aantal } \\
\text { populatie }\end{array}$ & $\begin{array}{c}\text { verder } \\
\text { leren }\end{array}$ & $\begin{array}{r}\text { zelfde } \\
\text { opleiding } \\
\text { opnieuw? }\end{array}$ & $\begin{array}{c}\text { werk- } \\
\text { loos- } \\
\text { heid }\end{array}$ & $\begin{array}{r}\text { intrede } \\
\text { werkloos- } \\
\text { heid }\end{array}$ & $\begin{array}{r}\text { flexibele } \\
\text { aan- } \\
\text { stelling }\end{array}$ & $\begin{array}{r}\text { bruto } \\
\text { uurloon }\end{array}$ & $\begin{array}{r}\text { minimaal } \\
\text { eigen } \\
\text { niveau }\end{array}$ & $\begin{array}{r}\text { eigen/ } \\
\text { verwante } \\
\text { richting }\end{array}$ \\
\hline & & $\%$ & $\%$ & $\%$ & maanden & $\%$ & $€$ & $\%$ & $\%$ \\
\hline
\end{tabular}

BOL niveau 3/4 (vervolg)

ZB Verpleging en verzorging

ZB Uiterlijke verzorging

ZB Sociaal pedagogisch werk

KF Plantenteelt

KF Veehouderij

$\mathrm{KF}$ voedingsmiddelentechnologie

KF Bloemschikken

KF Dierverzorging en veterinaire ondersteuning

KF Paardenhouderij en paardensport

KF Groene ruimte

KF Milieutoezicht

MKF Techniek

MKF Bouw

MKF Grond-, water- en wegenbouw

MKF Beschermings- en afwerkingstechnieken

MKF Reclame, presentatie en communicatie

MKF Operationele techniek

MKF Werktuigbouwkunde

MKF Motorvoertuigen

MKF Motorvoertuigen en carrosserietechniek

1.853

1.240

3.951
444
376

134

164

290

136

110

110

1.477
374
53

53
513

513
74

74
1261

492

MKF Energie- en informatietechniek

MKF Energietechniek

MKF Informatietechniek

MKF Edelsmeden

MKF Graf. techn, communicatie, audiovisueel en multimedia

MKF Laboratoriumtechniek

MKF Haven en vervoe

MKF Scheepvaart

$\begin{array}{rl}32 & 84 \\ 22 & 67 \\ 39 & 84 \\ 55 & 80 \\ 60 & 80 \\ 79 & 74 \\ 45 & 77 \\ 48 & 83 \\ - & 83 \\ 42 & 73 \\ 58 & 82 \\ - & 88 \\ 64 & 85 \\ 56 & 89 \\ - & 60 \\ 50 & 79 \\ - & 93 \\ 59 & 87 \\ 52 & 63 \\ - & 66 \\ 66 & 88 \\ - & 78 \\ 68 & 76 \\ - & 78 \\ 54 & 55 \\ 61 & 88 \\ - & 81 \\ - & 87\end{array}$

$\begin{array}{rrrr}25 & 9,18 & 82 & 65 \\ 47 & 6,92 & 52 & 77 \\ 38 & 8,25 & 74 & 53 \\ 53 & 7,69 & 62 & 56 \\ 31 & 8,12 & 64 & 65 \\ - & - & - & - \\ 45 & 6,71 & 48 & 62 \\ 49 & 7,01 & 58 & 51 \\ 24 & 6,43 & 40 & 71 \\ 52 & 9,11 & 62 & 92 \\ 20 & 9,68 & 92 & 43 \\ - & - & - & - \\ 41 & 8,70 & 68 & 52 \\ 54 & 9,08 & 54 & 65 \\ - & - & - & - \\ 41 & 8,08 & 57 & 90 \\ 9 & 12,96 & 82 & 83 \\ 38 & 9,46 & 76 & 83 \\ 44 & 7,79 & 65 & 86 \\ - & - & - & - \\ 36 & 8,17 & 86 & 77 \\ - & - & - & - \\ 51 & 8,61 & 88 & 69 \\ 24 & 7,67 & 64 & 59 \\ 52 & 8,62 & 76 & 91 \\ 18 & 9,62 & 85 & 90 \\ - & - & - & - \\ 22 & 11,02 & 78 & -\end{array}$


Tabel B4. 1 (vervolg)

Enkele kernindicatoren

\begin{tabular}{|c|c|c|c|c|c|c|c|c|c|}
\hline \multirow[t]{2}{*}{ Opleidingsrichting } & \multirow[t]{2}{*}{$\begin{array}{r}\text { opgehoogd } \\
\text { aantal } \\
\text { populatie }\end{array}$} & \multirow{2}{*}{$\begin{array}{r}\text { verder } \\
\text { leren } \\
\\
\%\end{array}$} & \multirow{2}{*}{$\begin{array}{r}\text { zelfde } \\
\text { opleiding } \\
\text { opnieuw? } \\
\%\end{array}$} & \multirow{2}{*}{$\begin{array}{r}\begin{array}{r}\text { werk- } \\
\text { loos- } \\
\text { heid }\end{array} \\
\%\end{array}$} & \multirow{2}{*}{$\begin{array}{r}\text { intrede } \\
\text { werkloos- } \\
\text { heid } \\
\text { maanden }\end{array}$} & \multirow{2}{*}{$\begin{array}{r}\text { flexibele } \\
\text { aan- } \\
\text { stelling } \\
\%\end{array}$} & \multirow{2}{*}{$\begin{array}{r}\text { bruto } \\
\text { uurloon } \\
€\end{array}$} & \multirow{2}{*}{$\begin{array}{r}\text { minimaal } \\
\text { eigen } \\
\text { niveau } \\
\%\end{array}$} & \multirow{2}{*}{$\begin{array}{r}\text { eigen/ } \\
\text { verwante } \\
\text { richting } \\
\%\end{array}$} \\
\hline & & & & & & & & & \\
\hline \multicolumn{10}{|l|}{ BOL niveau $\mathbf{3 / 4}$ (vervolg) } \\
\hline MKF Transport en logistiek & 361 & 30 & 70 & 7 & 0,7 & 29 & 8,40 & 64 & 54 \\
\hline MKF Automatisering & 740 & 63 & 55 & 23 & 3,2 & 59 & 8,76 & 61 & 44 \\
\hline MKF Bedrijfsadministratief & 1.898 & 66 & 83 & 5 & 1,7 & 52 & 8,02 & 90 & 80 \\
\hline MKF Commercieel & 2.458 & 66 & 72 & 13 & 2,0 & 45 & 7,56 & 80 & 57 \\
\hline MKF Economisch-juridisch & 484 & 74 & 69 & 40 & 1,1 & - & - & - & - \\
\hline MKF Secretarieel & 1.511 & 47 & 68 & 11 & 1,5 & 49 & 7,82 & 79 & 66 \\
\hline MKF Detailhandel/ambulante handel & 2.266 & 53 & 57 & 13 & 0,8 & 40 & 7,46 & 51 & 48 \\
\hline MKF Groothandel/distributie & 921 & 69 & 80 & 8 & 0,3 & - & - & - & - \\
\hline MKF Horeca, instellingskeuken en contractcatering & 1.050 & 46 & 78 & 10 & 0,9 & 38 & 8,80 & 67 & 64 \\
\hline MKF Toerisme, recreatie en reizen & 1.156 & 49 & 73 & 11 & 1,4 & 46 & 7,90 & 78 & 52 \\
\hline MKF Assistenten gezondheidszorg & 1.786 & 33 & 84 & 6 & 0,6 & 23 & 8,81 & 84 & 84 \\
\hline MKF Facilitaire dienstverlening & 410 & 64 & 69 & 24 & 1,6 & 57 & 7,25 & 41 & 46 \\
\hline MKF Sport en bewegen & 805 & 60 & 88 & 7 & 1,5 & 52 & 9,64 & 58 & 71 \\
\hline MKF Verpleging en verzorging & 1.287 & 33 & 81 & 4 & 0,5 & 26 & 10,54 & 97 & 92 \\
\hline MKF Sociaal-cultureel werker & 290 & - & 59 & 30 & 0,6 & - & - & - & - \\
\hline MKF Sociaal-pedagogisch werk algemeen & 4.963 & 57 & 84 & 10 & 1,0 & 39 & 9,15 & 86 & 79 \\
\hline MKF Sociaal-juridisch werk & 838 & 71 & 68 & 20 & 1,8 & 62 & 9,81 & 74 & 59 \\
\hline Specialist Informatietechniek & 41 & 83 & 33 & 0 & 2,4 & - & - & - & - \\
\hline Specialist Automatisering & 567 & 55 & 67 & 0 & 0,6 & - & - & - & - \\
\hline \multicolumn{10}{|l|}{ BBL niveau $1 / 2$} \\
\hline$A B$ Groene ruimte & 650 & 22 & 61 & 7 & 0,3 & 14 & 8,67 & 38 & 44 \\
\hline AB Horeca, instellingskeuken en contractcatering & 648 & - & 55 & 13 & 1,0 & 46 & 9,38 & 25 & 43 \\
\hline$A B$ Verpleging en verzorging & 445 & - & 78 & 0 & 0,1 & - & 8,99 & 16 & 63 \\
\hline BB Plantenteelt & 174 & - & 51 & 0 & 0,0 & 6 & 7,19 & 45 & 25 \\
\hline BB Bloemschikken & 287 & 36 & 77 & 2 & 0,4 & 29 & 5,74 & 53 & 62 \\
\hline BB Dierverzorging en veterinaire ondersteuning & 62 & - & 41 & 8 & 0,2 & - & - & - & - \\
\hline BB Groene ruimte & 557 & 39 & 75 & 2 & 0,2 & 17 & 8,33 & 52 & 58 \\
\hline
\end{tabular}


Tabel B4. 1 (vervolg)

Enkele kernindicatoren

\begin{tabular}{|c|c|c|c|c|c|c|c|c|c|}
\hline \multirow[t]{2}{*}{ Opleidingsrichting } & \multirow[t]{2}{*}{$\begin{array}{r}\text { opgehoogd } \\
\text { aantal } \\
\text { populatie }\end{array}$} & \multirow{2}{*}{$\begin{array}{r}\text { verder } \\
\text { leren } \\
\\
\%\end{array}$} & \multirow{2}{*}{$\begin{array}{r}\text { zelfde } \\
\text { opleiding } \\
\text { opnieuw? } \\
\%\end{array}$} & \multirow{2}{*}{$\begin{array}{r}\begin{array}{c}\text { werk- } \\
\text { loos- } \\
\text { heid } \\
\%\end{array}\end{array}$} & \multirow{2}{*}{$\begin{array}{r}\text { intrede } \\
\text { werkloos- } \\
\text { heid } \\
\text { maanden }\end{array}$} & \multirow{2}{*}{$\begin{array}{r}\text { flexibele } \\
\text { aan- } \\
\text { stelling } \\
\%\end{array}$} & \multirow{2}{*}{$\begin{array}{r}\text { bruto } \\
\text { uurloon } \\
€\end{array}$} & \multirow{2}{*}{$\begin{array}{r}\text { minimaal } \\
\text { eigen } \\
\text { niveau } \\
\%\end{array}$} & \multirow{2}{*}{$\begin{array}{r}\text { eigen/ } \\
\text { verwante } \\
\text { richting } \\
\%\end{array}$} \\
\hline & & & & & & & & & \\
\hline \multicolumn{10}{|l|}{ BBL niveau 1/2 (vervolg) } \\
\hline BB Bouw & 2.479 & - & 64 & 4 & 0,8 & 58 & 9,08 & 57 & 71 \\
\hline BB Motorvoertuigen & 902 & - & 60 & 8 & 0,1 & 36 & 10,25 & 64 & 67 \\
\hline BB Installatie-, service- en onderhoudstechniek & 949 & - & 73 & 5 & 0,6 & 63 & 7,58 & 58 & 84 \\
\hline BB Wegvervoer & 1.097 & - & 84 & 0 & 0,0 & 38 & 8,23 & 43 & 70 \\
\hline BB Detailhandel/ambulante handel & 1.591 & - & 39 & 0 & 0,1 & 29 & 8,05 & 28 & 29 \\
\hline BB Horeca, instellingskeuken en contractcatering & 1.541 & 44 & 72 & 6 & 0,5 & 49 & 7,19 & 75 & 75 \\
\hline BB Facilitaire dienstverlening & 409 & - & 87 & 0 & 0,0 & 7 & 11,72 & 33 & 93 \\
\hline BB Verpleging en verzorging & 3.162 & 21 & 86 & 10 & 1,3 & 15 & 10,73 & 70 & 80 \\
\hline \multicolumn{10}{|l|}{ BBL niveau $3 / 4$} \\
\hline ZB Plantenteelt & 134 & - & 59 & 0 & 0,1 & 21 & 9,68 & 28 & 51 \\
\hline ZB Bloemschikken & 166 & - & 81 & 1 & 0,6 & 13 & 7,64 & 36 & 67 \\
\hline ZB Groene ruimte & 323 & 27 & 89 & 3 & 0,4 & 15 & 10,03 & 34 & 66 \\
\hline ZB Bouw & 303 & - & 100 & 0 & 0,3 & - & - & - & \\
\hline ZB Motorvoertuigen & 979 & - & 73 & 0 & 0,0 & 18 & 10,12 & 54 & 82 \\
\hline ZB Horeca, instellingskeuken en contractcatering & 1.021 & 36 & 78 & 0 & 0,1 & 46 & 9,47 & 75 & 65 \\
\hline ZB Verpleging en verzorging & 4.390 & - & 81 & 5 & 0,0 & 3 & 11,78 & 81 & 91 \\
\hline ZB Sociaal-pedagogisch werk & 1.548 & - & 83 & 4 & 2,6 & 4 & 12,50 & 93 & 100 \\
\hline KF Groene ruimte & 76 & - & 83 & 0 & 0,2 & - & & - & \\
\hline MKF Detailhandel/ambulante handel & 1.326 & - & 48 & 20 & 0,7 & 25 & 7,82 & 50 & 50 \\
\hline MKF Horeca, instellingskeuken en contractcatering & 167 & - & 81 & 4 & 0,6 & 35 & 7,95 & 57 & 59 \\
\hline MKF Verpleging en verzorging & 2.914 & - & 89 & 1 & 0,0 & 4 & 14,29 & 95 & 93 \\
\hline MKF Sociaal-pedagogisch werk & 1.208 & - & 82 & 3 & 0,3 & 11 & 12,28 & 71 & 94 \\
\hline
\end{tabular}

$\mathrm{x}=$ vraag niet opgenomen

Zie ook toelichting bladzijde 50 en de tabellen C.5, B2.1, B1.4, B3.1, B3.3, B3.7, B3.8 en B3.9. 
C. Respons 



\section{Inhoud}

C.1 Ongewogen aantal respondenten verbijzonderd naar bestemming per opleidingssector

C.2 Naar landelijke populatie gewogen aantal schoolverlaters verbijzonderd naar bestemming per opleidingssector

C.3 Responspercentage per opleidingssector

C.4 Ongewogen aantal respondenten verbijzonderd naar bestemming per opleidingsrichting

C.5 Naar landelijke populatie gewogen aantal schoolverlaters verbijzonderd naar bestemming per opleidingsrichting

C.6 Responspercentage per opleidingsrichting 
Tabel C.1

Ongewogen aantal respondenten verbijzonderd naar bestemming per opleidingssector

\begin{tabular}{|c|c|c|c|c|c|c|c|}
\hline Opleidingssector & studie & BBL & $\begin{array}{r}\text { betaald } \\
\text { werk }\end{array}$ & $\begin{array}{r}\text { werk- } \\
\text { loos }\end{array}$ & anders & $\begin{array}{l}\text { on- } \\
\text { bekend }\end{array}$ & totaal \\
\hline HAVO/VWO & 3.254 & 67 & 136 & 27 & 56 & 86 & 3.626 \\
\hline HAVO & 1.646 & 52 & 104 & 23 & 37 & 40 & 1.902 \\
\hline VWO & 1.608 & 15 & 32 & 4 & 19 & 46 & 1.724 \\
\hline Vмво & 1.917 & 447 & 329 & 56 & 61 & 63 & 2.873 \\
\hline Theoretische leerweg & 833 & 52 & 47 & 7 & 18 & 23 & 980 \\
\hline Landbouw & 641 & 199 & 146 & 34 & 26 & 28 & 1.074 \\
\hline Techniek & 120 & 124 & 77 & 3 & 9 & 7 & 340 \\
\hline Economie & 145 & 39 & 40 & 8 & 4 & 4 & 240 \\
\hline Gezondheidszorg & 178 & 33 & 19 & 4 & 4 & 1 & 239 \\
\hline BOL niveau $1 / 2$ & 273 & 155 & 324 & 86 & 66 & 11 & 915 \\
\hline Landbouw & 16 & 7 & 30 & 7 & 10 & 0 & 70 \\
\hline Techniek & 55 & 41 & 75 & 20 & 11 & 3 & 205 \\
\hline Economie & 139 & 89 & 174 & 48 & 28 & 6 & 484 \\
\hline Gezondheidszorg & 63 & 18 & 45 & 11 & 17 & 2 & 156 \\
\hline BOL niveau $3 / 4$ & 2.259 & 227 & 2.339 & 165 & 169 & 40 & 5.199 \\
\hline Landbouw & 272 & 37 & 371 & 29 & 35 & 8 & 752 \\
\hline Techniek & 574 & 42 & 501 & 31 & 33 & 12 & 1.193 \\
\hline Economie & 768 & 56 & 642 & 67 & 42 & 9 & 1.584 \\
\hline Gezondheidszorg & 243 & 48 & 476 & 13 & 24 & 6 & 810 \\
\hline Gedrag en maatschappij & 402 & 44 & 349 & 25 & 35 & 5 & 860 \\
\hline BBL niveau $1 / 2$ & 24 & 161 & 603 & 29 & 40 & 6 & 863 \\
\hline Landbouw & 6 & 72 & 271 & 7 & 21 & 3 & 380 \\
\hline Techniek & 7 & 43 & 106 & 9 & 9 & 0 & 174 \\
\hline Economie & 11 & 33 & 85 & 9 & 4 & 1 & 143 \\
\hline Gezondheidszorg & 0 & 13 & 141 & 4 & 6 & 2 & 166 \\
\hline BBL niveau $3 / 4$ & 83 & 49 & 738 & 24 & 56 & 2 & 952 \\
\hline Landbouw & 6 & 15 & 171 & 6 & 24 & 0 & 222 \\
\hline Techniek & 14 & 12 & 104 & 4 & 8 & 0 & 142 \\
\hline Economie & 45 & 5 & 121 & 6 & 6 & 0 & 183 \\
\hline Gezondheidszorg & 5 & 14 & 266 & 4 & 11 & 1 & 301 \\
\hline Gedrag en maatschappij & 13 & 3 & 76 & 4 & 7 & 1 & 104 \\
\hline HBO & 2.635 & $\mathbf{x}$ & 11.652 & 538 & 387 & 229 & 15.441 \\
\hline Landbouw & 132 & $\mathrm{X}$ & 459 & 32 & 16 & 15 & 654 \\
\hline Onderwijs & 126 & $x$ & 1.817 & 50 & 60 & 34 & 2.087 \\
\hline Techniek & 733 & $x$ & 2.232 & 107 & 61 & 35 & 3.168 \\
\hline Economie & 1.200 & $\mathrm{X}$ & 3.597 & 199 & 100 & 68 & 5.164 \\
\hline Gezondheidszorg & 142 & $x$ & 1.323 & 33 & 37 & 19 & 1.554 \\
\hline Gedrag en maatschappij & 221 & $x$ & 1.625 & 79 & 62 & 29 & 2.016 \\
\hline Taal en cultuur & 81 & $x$ & 599 & 38 & 51 & 29 & 798 \\
\hline wo & 447 & $\mathbf{x}$ & 7.683 & 336 & 250 & 123 & 8.839 \\
\hline Landbouw & 12 & $\mathrm{x}$ & 305 & 15 & 4 & 1 & 337 \\
\hline Techniek & 28 & $\mathrm{X}$ & 1.249 & 43 & 27 & 18 & 1.365 \\
\hline Economie & 32 & $x$ & 1.319 & 46 & 32 & 23 & 1.452 \\
\hline Gezondheidszorg & 100 & $\mathrm{x}$ & 950 & 16 & 40 & 24 & 1.130 \\
\hline Gedrag en maatschappij & 87 & $\mathrm{X}$ & 1.624 & 100 & 69 & 15 & 1.895 \\
\hline Taal en cultuur & 81 & $\mathrm{x}$ & 759 & 58 & 48 & 14 & 960 \\
\hline Recht en openbare orde & 36 & $\mathrm{X}$ & 882 & 32 & 12 & 15 & 977 \\
\hline Natuurwetenschappen & 71 & $x$ & 595 & 26 & 18 & 13 & 723 \\
\hline
\end{tabular}


Tabel C.1 (vervolg)

Ongewogen aantal respondenten verbijzonderd naar bestemming per opleidingssector

\begin{tabular}{lrrrrrrr}
\hline Opleidingssector & studie & BBL & $\begin{array}{r}\text { betaald } \\
\text { werk }\end{array}$ & $\begin{array}{r}\text { werk- } \\
\text { loos }\end{array}$ & anders & $\begin{array}{r}\text { on- } \\
\text { bekend }\end{array}$ & totaal \\
\hline Totaal & 10.892 & 1.106 & 23.804 & 1.261 & 1.085 & 560 & 38.708 \\
\hline
\end{tabular}

$\mathrm{x}=$ antwoordcategorie niet opgenomen

Toelichting

De aantallen in deze tabel betreffen het feitelijke aantal respondenten van wie de gegevens in deze rapportage zijn opgenomen. 
Tabel C.2

Naar landelijke populatie gewogen aantal schoolverlaters verbijzonderd naar bestemming per opleidingssector

\begin{tabular}{|c|c|c|c|c|c|c|c|}
\hline & studie & $\mathrm{BBL}$ & $\begin{array}{l}\text { betaald } \\
\text { werk }\end{array}$ & $\begin{array}{c}\text { werk- } \\
\text { loos }\end{array}$ & anders & $\begin{array}{r}\text { on- } \\
\text { bekend }\end{array}$ & totaal \\
\hline HAVO/VWO & 54.929 & 1254 & 2.408 & 498 & 913 & 206 & 60.208 \\
\hline HAVO & 30.160 & 997 & 1.877 & 434 & 644 & 114 & 34.226 \\
\hline VWO & 24.768 & 257 & 531 & 64 & 270 & 92 & 25.982 \\
\hline VMBO & 54.613 & 11165 & 9.192 & 1.044 & 1.756 & 1.369 & 79.138 \\
\hline Theoretische leerweg & 32.682 & 1985 & 1.753 & 259 & 735 & 729 & 38.143 \\
\hline Landbouw & 3.674 & 1152 & 780 & 186 & 171 & 140 & 6.103 \\
\hline Techniek & 4.507 & 5093 & 4.045 & 60 & 435 & 231 & 14.371 \\
\hline Economie & 6.648 & 1533 & 1.807 & 334 & 200 & 216 & 10.738 \\
\hline Gezondheidszorg & 7.101 & 1401 & 807 & 204 & 217 & 53 & 9.783 \\
\hline BOL niveau $1 / 2$ & 5.393 & 2325 & 4.935 & 1.621 & 1.181 & 72 & 15.528 \\
\hline Landbouw & 75 & 22 & 127 & 31 & 32 & 0 & 287 \\
\hline Techniek & 1.033 & 627 & 957 & 310 & 230 & 11 & 3.167 \\
\hline Economie & 2.818 & 1171 & 2.928 & 1.087 & 509 & 45 & 8.557 \\
\hline Gezondheidszorg & 1.467 & 505 & 924 & 193 & 411 & 17 & 3.517 \\
\hline BOL niveau $3 / 4$ & 21.141 & 2021 & 19.983 & 1.493 & 1.558 & 148 & 46.343 \\
\hline Landbouw & 1.290 & 178 & 1.688 & 124 & 147 & 33 & 3.460 \\
\hline Techniek & 5.446 & 347 & 4.031 & 295 & 235 & 37 & 10.391 \\
\hline Economie & 7.613 & 569 & 5.537 & 620 & 465 & 41 & 14.845 \\
\hline Gezondheidszorg & 2.084 & 478 & 4.445 & 118 & 248 & 24 & 7.396 \\
\hline Gedrag en maatschappij & 4.708 & 449 & 4.282 & 337 & 463 & 13 & 10.251 \\
\hline BBL niveau $1 / 2$ & 915 & 4073 & 13.746 & 1.096 & 771 & 49 & 20.651 \\
\hline Landbouw & 35 & 358 & 1.508 & 34 & 119 & 13 & 2.067 \\
\hline Techniek & 288 & 1876 & 5.639 & 447 & 342 & 0 & 8.592 \\
\hline Economie & 592 & 1215 & 3.449 & 348 & 239 & 1 & 5.843 \\
\hline Gezondheidszorg & 0 & 624 & 3.151 & 267 & 71 & 35 & 4.148 \\
\hline BBL niveau $3 / 4$ & 1.336 & 950 & 15.353 & 552 & 950 & 100 & 19.240 \\
\hline Landbouw & 28 & 69 & 799 & 21 & 112 & 0 & 1.028 \\
\hline Techniek & 209 & 323 & 2.373 & 40 & 168 & 0 & 3.112 \\
\hline Economie & 702 & 138 & 2.467 & 251 & 104 & 0 & 3.661 \\
\hline Gezondheidszorg & 124 & 340 & 7.443 & 172 & 431 & 99 & 8.609 \\
\hline Gedrag en maatschappij & 274 & 80 & 2.272 & 68 & 135 & 1 & 2.830 \\
\hline HBO & 8.096 & $x$ & 35.712 & 1.704 & 1.215 & 263 & 46.990 \\
\hline Landbouw & 364 & $\mathrm{x}$ & 1.309 & 96 & 47 & 18 & 1.834 \\
\hline Onderwijs & 514 & $\mathrm{x}$ & 6.615 & 197 & 235 & 42 & 7.603 \\
\hline Techniek & 2.208 & $\mathrm{x}$ & 6.830 & 328 & 199 & 42 & 9.607 \\
\hline Economie & 3.729 & $x$ & 10.804 & 635 & 309 & 77 & 15.552 \\
\hline Gezondheidszorg & 403 & $\mathrm{x}$ & 3.940 & 130 & 117 & 20 & 4.610 \\
\hline Gedrag en maatschappij & 674 & $\mathrm{x}$ & 4.718 & 222 & 188 & 33 & 5.834 \\
\hline Taal en cultuur & 204 & $\mathrm{x}$ & 1.496 & 97 & 121 & 31 & 1.949 \\
\hline wo & 1.076 & $\mathbf{x}$ & 18.491 & 809 & 602 & 296 & 21.273 \\
\hline Landbouw & 29 & $x$ & 734 & 36 & 10 & 2 & 811 \\
\hline Techniek & 67 & $x$ & 3.006 & 103 & 65 & 43 & 3.285 \\
\hline Economie & 77 & $x$ & 3.174 & 111 & 77 & 55 & 3.495 \\
\hline Gezondheidszorg & 241 & $x$ & 2.286 & 39 & 96 & 58 & 2.720 \\
\hline Gedrag en maatschappij & 209 & $x$ & 3.909 & 241 & 166 & 36 & 4.561 \\
\hline Taal en cultuur & 195 & $x$ & 1.827 & 140 & 116 & 34 & 2.310 \\
\hline Recht en openbare orde & 87 & $\mathrm{x}$ & 2.123 & 77 & 29 & 36 & 2.351 \\
\hline
\end{tabular}


Tabel C.2 (vervolg)

Naar landelijke populatie gewogen aantal schoolverlaters verbijzonderd naar bestemming per opleidingssector

\begin{tabular}{lrrrrrrr}
\hline & studie & BBL & $\begin{array}{r}\text { betaald } \\
\text { werk }\end{array}$ & $\begin{array}{r}\text { werk- } \\
\text { loos }\end{array}$ & anders $\begin{array}{r}\text { on- } \\
\text { bekend }\end{array}$ & totaal \\
\hline Natuurwetenschappen & 171 & $\mathrm{X}$ & 1.432 & 63 & 43 & 31 & 1.740 \\
Totaal & $\mathbf{1 4 7 . 4 9 8}$ & $\mathbf{2 1 . 7 8 7}$ & $\mathbf{1 1 9 . 8 2 1}$ & $\mathbf{8 . 8 1 6}$ & $\mathbf{8 . 9 4 8}$ & $\mathbf{2 . 5 0 2}$ & $\mathbf{3 0 9 . 3 7 2}$ \\
\hline $\mathrm{X}=$ antwoordcategorie niet opgenomen & & & & & & &
\end{tabular}

Toelichting

De aantallen in deze tabel zijn zodanig opgehoogd dat een representatief beeld wordt gegeven van de totale populatie van schoolverlaters. 
Tabel C.3

Responspercentage per opleidingssector

Opleidingssector

HAVO/VWO

HAVO

VWO

VMBo

66

Theoretische leerweg

Landbouw

Techniek

Economie

Gezondheidszorg

48

BOL niveau $1 / 2$

Landbouw

Techniek

Economie

Gezondheidszorg

BOL niveau $3 / 4$

Landbouw

Techniek

Economie

31

Gezondheidszorg

Gedrag en maatschappij

BBL niveau 1/2

Landbouw

Techniek

Economie

Gezondheidszorg

BBL niveau 3/4

Landbouw

Techniek

Economie

Gezondheidszorg

Gedrag en maatschappij

HBO

Landbouw

Onderwijs

Techniek

Economie

Gezondheidszorg

Gedrag en maatschappij

Gezondheidszorg

Gedrag en maatschappij

Taal en cultuur

Recht en openbare orde 
Tabel C.3 (vervolg)

Responspercentage per opleidingssector

Opleidingssector

Totaal

45

Toelichting

De responspercentages geven een beeld van het aandeel van de uitgezette vragenlijsten dat bruikbaar retour is gekomen. De responspercentages van het WO hebben betrekking op 11 universiteiten. 
Tabel C. 4

Ongewogen aantal respondenten verbijzonderd naar bestemming per opleidingsrichting

\begin{tabular}{|c|c|c|c|c|c|c|c|}
\hline Opleidingsrichting & studie & BBL & betaald werk & werkloos & anders & onbekend & totaal \\
\hline \multicolumn{8}{|l|}{ VMBO } \\
\hline Theoretische leerweg & 833 & 52 & 47 & 7 & 18 & 23 & 980 \\
\hline Landbouw Gem Iw landbouw en nat.omgeving & 99 & 14 & 13 & 2 & 0 & 3 & 131 \\
\hline Landbouw KB landbouw en nat.omgeving & 309 & 59 & 34 & 9 & 10 & 9 & 430 \\
\hline Landbouw BB landbouw en nat.omgeving & 217 & 119 & 96 & 21 & 16 & 15 & 484 \\
\hline Techniek KB bouwtechniek & 19 & 16 & 6 & 0 & 0 & 0 & 41 \\
\hline Techniek KB voertuigentechniek & 5 & 12 & 5 & 1 & 1 & 0 & 24 \\
\hline Techniek KB electrotechniek & 23 & 10 & 7 & 0 & 1 & 1 & 42 \\
\hline Techniek KB overig & 10 & 5 & 1 & 0 & 0 & 0 & 16 \\
\hline Techniek BB bouwtechniek & 11 & 17 & 20 & 0 & 1 & 2 & 51 \\
\hline Techniek BB metaaltechniek & 4 & 9 & 13 & 0 & 2 & 1 & 29 \\
\hline Techniek BB voertuigentechniek & 2 & 19 & 8 & 0 & 0 & 1 & 30 \\
\hline Techniek BB electrotechniek & 8 & 8 & 6 & 0 & 1 & 0 & 23 \\
\hline Techniek BB overig & 3 & 12 & 2 & 1 & 1 & 1 & 20 \\
\hline Economie KB & 12 & 3 & 1 & 0 & 0 & 0 & 16 \\
\hline Economie KB administratie & 21 & 3 & 2 & 0 & 1 & 1 & 28 \\
\hline Economie KB handel en administratie & 30 & 8 & 8 & 2 & 1 & 2 & 51 \\
\hline Economie BB administratie & 21 & 2 & 5 & 1 & 0 & 0 & 29 \\
\hline Economie BB handel en verkoop & 8 & 4 & 5 & 0 & 1 & 0 & 18 \\
\hline Economie BB handel en administratie & 13 & 5 & 2 & 0 & 1 & 0 & 21 \\
\hline Economie BB consumptief & 11 & 9 & 9 & 2 & 0 & 0 & 31 \\
\hline Zorg en Welzijn Gem Iw zorg en welzijn-breed & 21 & 0 & 1 & 0 & 0 & 0 & 22 \\
\hline Zorg en Welzijn KB & 15 & 0 & 0 & 0 & 0 & 0 & 15 \\
\hline Zorg en Welzijn KB verzorging & 34 & 7 & 7 & 1 & 1 & 0 & 50 \\
\hline Zorg en Welzijn KB zorg en welzijn-breed & 34 & 6 & 3 & 0 & 1 & 1 & 45 \\
\hline Zorg en Welzijn BB verzorging & 36 & 9 & 4 & 1 & 0 & 0 & 50 \\
\hline Zorg en Welzijn BB zorg en welzijn-breed & 18 & 4 & 4 & 1 & 2 & 0 & 29 \\
\hline \multicolumn{8}{|l|}{ BOL niveau $1 / 2$} \\
\hline AB Beveiliging & 11 & 4 & 25 & 3 & 2 & 0 & 45 \\
\hline AB Secretarieel & 12 & 1 & 7 & 9 & 2 & 1 & 32 \\
\hline BB Bloemschikken & 3 & 3 & 8 & 3 & 0 & 0 & 17 \\
\hline BB Dierverzorging en veterinaire ondersteuning & 6 & 2 & 9 & 2 & 6 & 0 & 25 \\
\hline
\end{tabular}


Tabel C. 4 (vervolg)

Ongewogen aantal respondenten verbijzonderd naar bestemming per opleidingsrichting

\begin{tabular}{llllll}
\hline Opleidingsrichting & studie & BBL betaald werk werkloos anders onbekend
\end{tabular}

BOL niveau $1 / 2$ (vervolg)

BB Motorvoertuigen

BB Informatietechniek

BB Scheepvaart

BB Bedriffsadministratie

BB Beveiliging

BB Detailhandel/ambulante handel

BB Horeca, instellingskeuken en contractcatering

BB Toerisme, recreatie en reizen

$\begin{array}{rr} & \\ 4 & 10 \\ 17 & 3 \\ 3 & 0 \\ 17 & 4 \\ 25 & 6 \\ 15 & 1 \\ 18 & 5 \\ 23 & 62 \\ 4 & 1 \\ 53 & 16\end{array}$

10
3
0
4
6
1
5
62
1
16

$\begin{array}{rr}11 & \\ 10 & \\ 15 & \\ 19 & \\ 45 & \\ 16 & \\ 11 & 6 \\ 33 & \\ 9 & \\ 31 & 10\end{array}$

\section{BOL niveau $3 / 4$}

ZB Plantenteelt

ZB Veehouderij

ZB Bloemschikken

ZB Dierverzorging en veterinaire ondersteuning

ZB Paardenhouderij en paardensport

ZB Groene

ZB Graf. techn, communicatie, audiovisueel en multimedia

ZB Scheepvaart

ZB Automatisering

ZB Bedrijfsadministratief

ZB Toerisme, recreatie en reizen

ZB Verpleging en verzorging

ZB Uiterlijke verzorging

ZB Sociaal pedagogisch werk

KF Plantenteelt

KF Veehouderij

$\mathrm{KF}$ voedingsmiddelentechnologie

KF Bloemschikken

KF Dierverzorging en veterinaire ondersteuning

KF Paardenhouderij en paardensport

7
7
6
22
3
16
3
3
5
4
11
20
19
91
18
41
20
15
45
11


Tabel C.4 (vervolg)

Ongewogen aantal respondenten verbijzonderd naar bestemming per opleidingsrichting

\begin{tabular}{llllll}
\hline Opleidingsrichting & studie & BBL betaald werk werkloos anders onbekend
\end{tabular}

BOL niveau 3/4 (vervolg)

KF Groene ruimte

KF Milieutoezicht

MKF Technie

MKF Bouw

MKF Grond-, water- en wegenbouw

MKF Beschermings- en afwerkingstechnieken

MKF Reclame, presentatie en communicatie

MKF Operationele techniek

MKF Werktuigbouwkunde

MKF Motorvoertuigen

MKF Motorvoertuigen en carrosserietechniek

MKF Energie- en informatietechniek

MKF Energietechniek

MKF Informatietechniek

MKF Edelsmeden

MKF Graf. techn, communicatie, audiovisueel en multimedia

MKF Laboratoriumtechniek

MKF Haven en vervoer

MKF Scheepvaart

MKF Transport en logistiek

MKF Automatisering

MKF Bedrifssadministratie

MKF Commercieel

MKF Economisch-juridisch

MKF Secretarieel

MKF Detailhandel/ambulante hande

MKF Groothandel/distributie

MKF Horeca, instellingskeuken en contractcatering

MKF Toerisme, recreatie en reizen

MKF Assistenten gezondheidszorg

MKF Facilitaire dienstverlening

MKF Sport en bewegen

$\begin{array}{rr}43 & 4 \\ 16 & 3 \\ 11 & 1 \\ 84 & 7 \\ 29 & 0 \\ 6 & 0 \\ 35 & 0 \\ 4 & 0 \\ 56 & 1 \\ 19 & 3 \\ 6 & 2 \\ 30 & 0 \\ 12 & 1 \\ 111 & 6 \\ 7 & 1 \\ 20 & 1 \\ 36 & 5 \\ 2 & 0 \\ 14 & 2 \\ 27 & 0 \\ 48 & 0 \\ 83 & 12 \\ 105 & 6 \\ 21 & 0 \\ 52 & 1 \\ 121 & 11 \\ 21 & 0 \\ 121 & 14 \\ 131 & 3 \\ 64 & 6 \\ 24 & 2 \\ 70 & 4\end{array}$

$\begin{array}{rr}2 & 113 \\ 0 & 34 \\ 1 & 19 \\ 1 & 138 \\ 0 & 53 \\ 0 & 18 \\ 0 & 62 \\ 0 & 34 \\ 0 & 97 \\ 1 & 44 \\ 0 & 17 \\ 4 & 55 \\ 1 & 29 \\ 0 & 170 \\ 1 & 28 \\ 0 & 42 \\ 0 & 68 \\ 0 & 16 \\ 1 & 47 \\ 1 & 64 \\ 0 & 88 \\ 1 & 149 \\ 2 & 170 \\ 0 & 29 \\ 0 & 120 \\ 2 & 222 \\ 1 & 35 \\ 0 & 280 \\ 0 & 254 \\ 1 & 217 \\ 0 & 42 \\ 2 & 119\end{array}$


Tabel C.4 (vervolg)

Ongewogen aantal respondenten verbijzonderd naar bestemming per opleidingsrichting

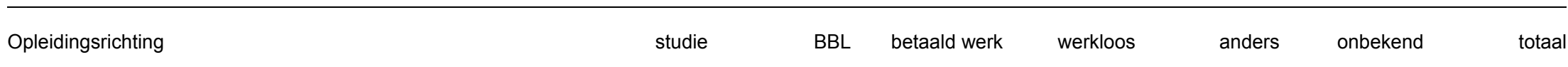

BOL niveau 3/4 (vervolg)

MKF Verpleging en verzorging

MKF Sociaal-cultureel werker

MKF Sociaal-pedagogisch werk algemeen

MKF Sociaal-juridisch werk

Specialist Informatietechniek

betaald werk

werkloos

taal

Specialist Automatisering

BBL niveau $1 / 2$

$A B$ Groene ruimte

$A B$ Horeca, instellingskeuken en contractcatering

$A B$ Verpleging en verzorging

BB Plantenteelt

BB Bloemschikken

BB Dierverzorging en veterinaire ondersteuning

BB Groene ruimte

BB Bouw

BB Motorvoertuigen

BB Installatie-, service-en onderhoudstechniek

BB Wegvervoer

BB Detailhandel/ambulante handel

BB Horeca, instellingskeuken en contractcatering

BB Facilitaire dienstverlening

$B B$ Verpleging en verzorging

BBL niveau $3 / 4$

ZB Plantenteelt

ZB Bloemschikken

ZB Groene ruimte

ZB Bouw

ZB Motorvoertuigen

ZB Horeca, instellingskeuken en contractcatering

ZB Verpleging en verzorging

$Z B$ Social-pedagogisch werk

40
11
258
35
17
21

14
1
38
1
1
0

109
8
201
11
3
17

3
3
8
1
0
0

3
1
19
2
0
2


Tabel C.4 (vervolg)

Ongewogen aantal respondenten verbijzonderd naar bestemming per opleidingsrichting

\begin{tabular}{|c|c|c|c|c|c|c|c|}
\hline Opleidingsrichting & studie & BBL & betaald werk & werkloos & anders & onbekend & totaal \\
\hline \multicolumn{8}{|l|}{ BBL niveau 3/4 (vervolg) } \\
\hline KF Groene ruimte & 1 & 1 & 14 & 0 & 0 & 0 & 16 \\
\hline MKF Detailhandel/ambulante handel & 7 & 1 & 14 & 3 & 1 & 0 & 26 \\
\hline MKF Horeca, instellingskeuken en contractcatering & 8 & 1 & 24 & 1 & 2 & 0 & 36 \\
\hline MKF Verpleging en verzorging & 2 & 5 & 103 & 0 & 3 & 0 & 113 \\
\hline MKF Sociaal-pedagogisch werk & 4 & 3 & 37 & 0 & 3 & 1 & 48 \\
\hline Totaal & 4.257 & 903 & 3.824 & 308 & 331 & 115 & 9.738 \\
\hline
\end{tabular}


Tabel C.5

Naar landelijke populatie gewogen aantal schoolverlaters verbijzonderd naar bestemming per opleidingsrichting

\begin{tabular}{|c|c|c|c|c|c|c|c|}
\hline Opleidingsrichting & studie & BBL & $\begin{array}{r}\text { betaald } \\
\text { werk }\end{array}$ & werkloos & anders & onbekend & totaal \\
\hline \multicolumn{8}{|l|}{ Vмво } \\
\hline Theoretische leerweg & 32.682 & 1.985 & 1.753 & 259 & 735 & 729 & 38.143 \\
\hline Landbouw Gem Iw landbouw en nat.omgeving & 431 & 47 & 46 & 12 & 0 & 4 & 541 \\
\hline Landbouw KB landbouw en nat.omgeving & 1.626 & 254 & 148 & 29 & 70 & 29 & 2.156 \\
\hline Landbouw BB landbouw en nat.omgeving & 1.483 & 793 & 559 & 138 & 101 & 54 & 3.128 \\
\hline Techniek KB bouwtechniek & 685 & 520 & 143 & 0 & 0 & 0 & 1.348 \\
\hline Techniek KB voertuigentechniek & 185 & 443 & 185 & 37 & 37 & 0 & 887 \\
\hline Techniek KB electrotechniek & 992 & 431 & 260 & 0 & 43 & 1 & 1.728 \\
\hline Techniek KB overig & 46 & 12 & 2 & 0 & 0 & 0 & 60 \\
\hline Techniek BB bouwtechniek & 788 & 1.218 & 1.433 & 0 & 72 & 73 & 3.583 \\
\hline Techniek BB metaaltechniek & 291 & 655 & 874 & 0 & 146 & 73 & 2.038 \\
\hline Techniek BB voertuigentechniek & 107 & 1.015 & 427 & 0 & 0 & 53 & 1.602 \\
\hline Techniek BB electrotechniek & 461 & 360 & 342 & 0 & 77 & 0 & 1.239 \\
\hline Techniek BB overig & 7 & 69 & 5 & 2 & 2 & 2 & 88 \\
\hline Economie KB & 56 & 21 & 8 & 0 & 0 & 0 & 84 \\
\hline Economie KB administratie & 1.162 & 176 & 105 & 0 & 71 & 52 & 1.565 \\
\hline Economie KB handel en administratie & 1.623 & 433 & 433 & 108 & 54 & 108 & 2.759 \\
\hline Economie BB administratie & 1.527 & 145 & 364 & 73 & 0 & 0 & 2.109 \\
\hline Economie BB handel en verkoop & 348 & 167 & 186 & 0 & 49 & 0 & 750 \\
\hline Economie BB handel en administratie & 691 & 130 & 52 & 0 & 26 & 0 & 899 \\
\hline Economie BB consumptief & 410 & 276 & 323 & 94 & 0 & 0 & 1.103 \\
\hline Zorg en Welzijn Gem Iw zorg en welzijn-breed & 613 & 0 & 14 & 0 & 0 & 0 & 627 \\
\hline Zorg en Welzijn KB & 52 & 0 & 0 & 0 & 0 & 0 & 52 \\
\hline Zorg en Welzijn KB verzorging & 1.151 & 237 & 237 & 34 & 34 & 0 & 1.692 \\
\hline Zorg en Welzijn KB zorg en welzijn-breed & 1.577 & 284 & 122 & 0 & 53 & 53 & 2.088 \\
\hline Zorg en Welzijn BB verzorging & 1.669 & 447 & 199 & 50 & 0 & 0 & 2.364 \\
\hline Zorg en Welzijn BB zorg en welzijn-breed & 1.238 & 260 & 236 & 53 & 130 & 0 & 1.916 \\
\hline \multicolumn{8}{|l|}{ BOL niveau $1 / 2$} \\
\hline AB Beveiliging & 400 & 132 & 800 & 131 & 79 & 0 & 1.542 \\
\hline AB Secretarieel & 417 & 40 & 270 & 345 & 78 & 40 & 1.189 \\
\hline BB Bloemschikken & 9 & 9 & 24 & 9 & 0 & 0 & 50 \\
\hline
\end{tabular}


Tabel C.5 (vervolg)

Naar landelijke populatie gewogen aantal schoolverlaters verbijzonderd naar bestemming per opleidingsrichting

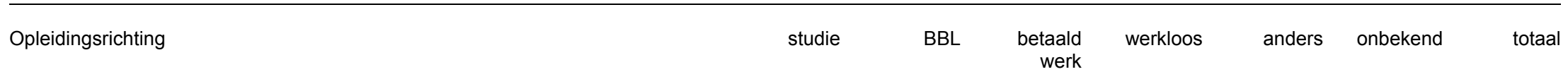

BOL niveau $1 / 2$ (vervolg)

BB Dierverzorging en veterinaire ondersteuning

BB Motorvoertuigen

BB Informatietechniek

BB Scheepvaart

BB Bedrijfsadministratie

BB Beveiliging

BB Detailhandel/ambulante handel

BB Horeca, instellingskeuken en contractcatering

BB Toerisme, recreatie en reizen

BB Verpleging en verzorging

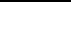

\section{BOL niveau $3 / 4$}

ZB Plantenteelt

ZB Veehouderij

ZB Bloemschikken

ZB Dierverzorging en veterinaire ondersteuning

ZB Paardenhouderij en paardensport

ZB Groene ruimte

ZB Groene ruimte

ZB Graf. techn,

ZB Scheepvaart

ZB Automatisering

ZB Toerisme, recreatie en reizen

ZB Verpleging en verzorging

ZB Uiterlijke verzorging

ZB Sociaal pedagogisch werk

KF Plantenteelt

KF Veehouderij

KF Bloemschikken

$\begin{array}{rrr}21 & 9 & 25 \\ 32 & 136 & 147 \\ 537 & 45 & 154 \\ 19 & 0 & 98 \\ 455 & 104 & 400 \\ 147 & 34 & 260 \\ 335 & 20 & 335 \\ 554 & 229 & 320 \\ 198 & 513 & 292 \\ 51 & 13 & 115 \\ 1.215 & 433 & 636\end{array}$

$\begin{array}{rrrrr}25 & 8 & 19 & 0 & 81 \\ 147 & 64 & 0 & 0 & 379 \\ 154 & 169 & 185 & 1 & 1.091 \\ 98 & 0 & 0 & 0 & 117 \\ 400 & 112 & 63 & 0 & 1.132 \\ 260 & 42 & 30 & 1 & 514 \\ 335 & 130 & 0 & 0 & 820 \\ 320 & 103 & 141 & 2 & 1.348 \\ 292 & 48 & 40 & 2 & 1.094 \\ 115 & 38 & 13 & 0 & 229 \\ 636 & 162 & 254 & 17 & 2.717\end{array}$

$\begin{array}{rrrrrrr}69 & 34 & 139 & 2 & 14 & 1 & 259 \\ 34 & 11 & 122 & 0 & 26 & 0 & 193 \\ 28 & 35 & 121 & 9 & 9 & 0 & 202 \\ 72 & 11 & 116 & 34 & 15 & 1 & 248 \\ 19 & 6 & 83 & 13 & 13 & 0 & 134 \\ 84 & 6 & 193 & 31 & 10 & 1 & 325 \\ 13 & 0 & 36 & 13 & 2 & 0 & 63 \\ 10 & 0 & 138 & 0 & 5 & 1 & 155 \\ 49 & 0 & 68 & 49 & 0 & 0 & 165 \\ 63 & 39 & 289 & 0 & 25 & 1 & 416 \\ 71 & 10 & 475 & 49 & 8 & 0 & 613 \\ 282 & 235 & 1.283 & 0 & 51 & 2 & 1.853 \\ 278 & 16 & 822 & 29 & 93 & 1 & 1.240 \\ 1.493 & 34 & 2.025 & 199 & 199 & 1 & 3.951 \\ 213 & 0 & 207 & 0 & 5 & 19 & 444 \\ 192 & 0 & 164 & 4 & 12 & 5 & 376 \\ 106 & 0 & 28 & 0 & 0 & 0 & 134 \\ 71 & 9 & 73 & 10 & 0 & 0 & 164\end{array}$


Tabel C.5 (vervolg)

Naar landelijke populatie gewogen aantal schoolverlaters verbijzonderd naar bestemming per opleidingsrichting

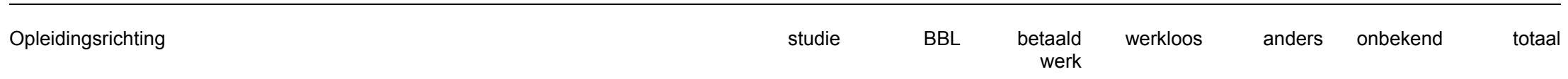

BOL niveau $3 / 4$ (vervolg)

KF Dierverzorging en veterinaire ondersteuning

KF Paardenhouderii en paardensport

KF Groene ruimte

KF Milieutoezicht

MKF Techniek

MKF Bouw

MKF Grond-, water- en wegenbouw

MKF Beschermings- en afwerkingstechnieken

MKF Reclame, presentatie en communicatie

MKF Operationele techniek

MKF Werktuigbouwkunde

MKF Motorvoertuigen

MKF Motorvoertuigen en carrosserietechniek

MKF Energie- en informatietechniek

MKF Energietechniek

MKF Informatietechniek

MKF Informatietechn

MKF Graf. techn, communicatie, audiovisueel en multimedia

MKF Graf. techn, comm

MKF Laboratoriumtechniek

MKF Haven en vervoer

MKF Transport en logistiek

MKF Automatisering

MKF Bedrijfsadministratie

MKF Commercieel

MKF Economisch-juridisch

MKF Secretarieel

MKF Detailhandel/ambulante hande

MKF Groothandel/distributie

MKF Horeca, instellingskeuken en contractcatering

MKF Toerisme, recreatie en reizen

$\begin{array}{rrr}136 & 18 & 119 \\ 48 & 18 & 63 \\ 163 & 18 & 217 \\ 50 & 12 & 34 \\ 11 & 1 & 6 \\ 919 & 72 & 434 \\ 205 & 0 & 151 \\ 14 & 0 & 34 \\ 290 & 0 & 199 \\ 7 & 0 & 58 \\ 730 & 11 & 465 \\ 211 & 35 & 222 \\ 10 & 3 & 34 \\ 403 & 0 & 269 \\ 161 & 13 & 161 \\ 1388 & 89 & 540 \\ 38 & 1 & 86 \\ 157 & 7 & 136 \\ 381 & 37 & 242 \\ 29 & 0 & 174 \\ 54 & 4 & 121 \\ 135 & 0 & 206 \\ 411 & 0 & 286 \\ 1.107 & 149 & 546 \\ 1.533 & 94 & 699 \\ 369 & 0 & 45 \\ 676 & 10 & 664 \\ 1.295 & 111 & 694 \\ 553 & 0 & 289 \\ 449 & 48 & 487 \\ 587 & 16 & 482 \\ & & \end{array}$

$\begin{array}{rr}119 & 6 \\ 63 & 0 \\ 217 & 3 \\ 34 & 9 \\ 6 & 0 \\ 434 & 16 \\ 151 & 19 \\ 34 & 2 \\ 199 & 0 \\ 58 & 6 \\ 465 & 32 \\ 222 & 23 \\ 34 & 0 \\ 269 & 0 \\ 161 & 0 \\ 540 & 59 \\ 86 & 7 \\ 136 & 23 \\ 242 & 68 \\ 174 & 0 \\ 121 & 4 \\ 206 & 7 \\ 286 & 34 \\ 546 & 56 \\ 699 & 82 \\ 45 & 35 \\ 664 & 74 \\ 694 & 86 \\ 289 & 0 \\ 487 & 25 \\ 482 & 54 \\ & \end{array}$

$\begin{array}{rr}6 & 11 \\ 0 & 6 \\ 3 & 20 \\ 9 & 6 \\ 0 & 0 \\ 16 & 28 \\ 19 & 0 \\ 2 & 2 \\ 0 & 25 \\ 6 & 3 \\ 32 & 23 \\ 23 & 0 \\ 0 & 0 \\ 0 & 0 \\ 0 & 28 \\ 59 & 38 \\ 7 & 19 \\ 23 & 7 \\ 68 & 0 \\ 0 & 29 \\ 4 & 3 \\ 7 & 7 \\ 34 & 9 \\ 56 & 33 \\ 82 & 47 \\ 35 & 35 \\ 74 & 87 \\ 86 & 79 \\ 0 & 53 \\ 25 & 41 \\ 54 & 18 \\ & \end{array}$

$\begin{array}{rrr}6 & 0 & 290 \\ 20 & 6 & 426 \\ 6 & 0 & 110 \\ 0 & 1 & 19 \\ 28 & 8 & 1.477 \\ 0 & 0 & 374 \\ 2 & 0 & 53 \\ 25 & 0 & 513 \\ 3 & 0 & 74 \\ 23 & 0 & 1261 \\ 0 & 1 & 492 \\ 0 & 0 & 47 \\ 0 & 16 & 689 \\ 28 & 1 & 364 \\ 38 & 0 & 2114 \\ 19 & 1 & 152 \\ 7 & 0 & 330 \\ 0 & 0 & 729 \\ 29 & 0 & 232 \\ 3 & 1 & 186 \\ 7 & 7 & 361 \\ 9 & 0 & 740 \\ 33 & 8 & 1.898 \\ 47 & 2 & 2.458 \\ 35 & 0 & 484 \\ 87 & 0 & 1.511 \\ 79 & 2 & 2.266 \\ 53 & 26 & 921 \\ 41 & 0 & 1.050 \\ 18 & 0 & 1.156\end{array}$


Tabel C.5 (vervolg)

Naar landelijke populatie gewogen aantal schoolverlaters verbijzonderd naar bestemming per opleidingsrichting

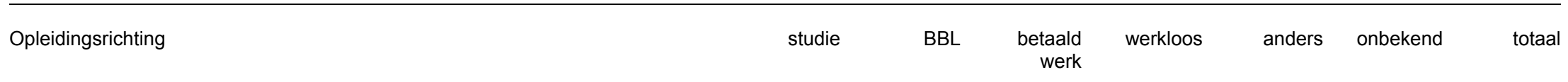

BOL niveau 3/4 (vervolg)

MKF Assistenten gezondheidszorg

MKF Facilitaire dienstverlening

MKF Sport en bewegen

MKF Verpleging en verzorging

MKF Sociaal-cultureet werker

MKF Sociaal-pedagogisch werk algemeen

MKF Social-juridisch werk

Specialist Informatietechniek

Specialist Automatisering

$\begin{array}{rrr}541 & 54 & 1097 \\ 238 & 20 & 104 \\ 456 & 30 & 287 \\ 283 & 122 & 845 \\ 138 & 13 & \\ 2.407 & 355 & 1.928 \\ 589 & 18 & 180 \\ 36 & 1 & \\ 290 & 0 & 246\end{array}$

$\begin{array}{rr}1097 & 33 \\ 104 & 29 \\ 287 & 7 \\ 845 & 18 \\ 89 & 38 \\ 1.928 & 73 \\ 180 & 16 \\ 4 & 0 \\ 246 & \end{array}$

$\begin{array}{rrrr}33 & 47 & 14 & 1.786 \\ 29 & 19 & 0 & 410 \\ 7 & 18 & 7 & 805 \\ 18 & 18 & 0 & 1.287 \\ 38 & 13 & 0 & 290 \\ 73 & 188 & 12 & 4.963 \\ 16 & 35 & 0 & 838 \\ 0 & 0 & 0 & 41 \\ 0 & 30 & 1 & 567\end{array}$

AB Groene ruim

$A B$ Horeca, instellingskeuken en contractcatering

$A B$ Verpleging en verzorging

BB Plantenteelt

BB Bloemschikken

BB Dierverzorging en veterinaire ondersteuning

BB Groene ruimte

BB Bouw

BB Motorvoertuigen

BB Installatie-, service- en onderhoudstechniek

BB Wegvervoer

BB Detailhandel/ambulante handel

BB Horeca, instellingskeuken en contractcatering

BB Facilitaire dienstverlening

BB Verpleging en verzorging

$\begin{array}{rrrrrrr}16 & 59 & 498 & 10 & 58 & 10 & 650 \\ 35 & 76 & 460 & 77 & 0 & 0 & 648 \\ 0 & 8 & 399 & 0 & 31 & 8 & 445 \\ 0 & 19 & 128 & 6 & 21 & 0 & 174 \\ 11 & 87 & 167 & 7 & 15 & 0 & 287 \\ 4 & 4 & 52 & 0 & 2 & 0 & 62 \\ 0 & 162 & 372 & 11 & 12 & 0 & 557 \\ 0 & 532 & 1.682 & 177 & 88 & 0 & 2.479 \\ 60 & 121 & 601 & 0 & 120 & 0 & 902 \\ 87 & 431 & 388 & 43 & 0 & 0 & 949 \\ 0 & 0 & 1.057 & 1 & 39 & 0 & 1.097 \\ 265 & 265 & 1.060 & 0 & 0 & 1 & 1.591 \\ 1 & 696 & 715 & 56 & 72 & 0 & 1.541 \\ 0 & 0 & 395 & 0 & 14 & 0 & 409 \\ 0 & 616 & 2.224 & 267 & 27 & 27 & 3.162\end{array}$

\section{BBL niveau 3/4}

ZB Plantenteelt

ZB Bloemschikken

ZB Groene ruimte

$\begin{array}{rrr}0 & 6 & 111 \\ 0 & 5 & 143 \\ 11 & 38 & 254\end{array}$

0
1

$\begin{array}{ll}0 & 17 \\ 1 & 16 \\ 9 & 12\end{array}$

134
166
323 
Tabel C.5 (vervolg)

Naar landelijke populatie gewogen aantal schoolverlaters verbijzonderd naar bestemming per opleidingsrichting

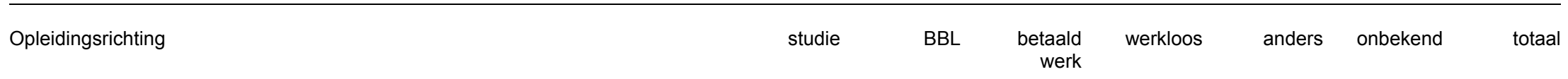

BBL niveau 3/4 (vervolg)

ZB Bouw

ZB Motorvoertuigen

ZB Horeca, instellingskeuken en contractcatering

ZB Verpleging en verzorging

ZB Sociaal-pedagogisch werk

KF Groene ruimte

MKF Detailhandel/ambulante hande

MKF Horeca, instellingskeuken en contractcatering

MKF Verpleging en verzorging

MKF Sociaal-pedagogisch werk

Totaal

$\begin{array}{rr}0 & \\ 0 & \\ 91 & \\ 49 & \\ 160 & \\ 7 & \\ 421 & \\ 32 & \\ 54 & \\ 81 & \\ & \\ .312 & \\ \end{array}$

$\begin{array}{rr}0 & 302 \\ 91 & 800 \\ 70 & 858 \\ 210 & 3.818 \\ 0 & 1.281 \\ 7 & 63 \\ 60 & 605 \\ 5 & 115 \\ 109 & 2.668 \\ 80 & 965 \\ & \\ \mathbf{6 7 4} & \mathbf{5 3 . 8 3 5}\end{array}$

$\begin{array}{rr}1 & 0 \\ 0 & 89 \\ 0 & 2 \\ 73 & 141 \\ 54 & 54 \\ 0 & 0 \\ 180 & 60 \\ 5 & 11 \\ 0 & 84 \\ 0 & 80 \\ & \\ \mathbf{4 . 6 1 3} & \mathbf{5 . 1 7 6}\end{array}$

0
89
2
141
54
0
60
11
84
80

$\begin{array}{rr}0 & 303 \\ 0 & 979 \\ 0 & 1.021 \\ 99 & 4.390\end{array}$


Tabel C.6

Responspercentage per opleidingsrichting

Opleidingsrichting

VMBO

Theoretische leerweg

Landbouw Gem Iw landbouw en nat.omgeving $\quad 60$

Landbouw KB landbouw en nat.omgeving $\quad 49$

Landbouw BB landbouw en nat.omgeving 38

Landbouw BB landbouw-breed $\quad 65$

$\begin{array}{ll}\text { Techniek KB } & 38\end{array}$

Techniek KB bouwtechniek $\quad 60$

Techniek KB metaaltechniek $\quad 52$

Techniek KB voertuigentechniek $\quad 52$

Techniek KB electrotechniek $\quad 48$

$\begin{array}{ll}\text { Techniek KB grafische techniek } & 41\end{array}$

Techniek KB overig $\quad 53$

Techniek BB $\quad 28$

$\begin{array}{ll}\text { Techniek BB bouwtechniek } & 35\end{array}$

Techniek BB metaaltechniek 38

$\begin{array}{ll}\text { Techniek BB voertuigentechniek } & 48\end{array}$

Techniek BB electrotechniek $\quad 37$

$\begin{array}{ll}\text { Techniek BB grafische techniek } & 20\end{array}$

$\begin{array}{ll}\text { Techniek BB overig } & 48\end{array}$

Economie Gem Iw $\quad 35$

Economie Gem Iw handel en administratie $\quad 44$

Economie KB

Economie KB administratie $\quad 42$

Economie KB handel en verkoop $\quad 56$

Economie KB handel en administratie $\quad 42$

$\begin{array}{ll}\text { Economie KB consumptief } & 38\end{array}$

Economie BB

Economie BB administratie $\quad 38$

Economie BB handel en administratie $\quad 28$

Economie BB consumptief $\quad 38$

Zorg en Welzijn Gem Iw zorg en welzijn-breed $\quad 65$

Zorg en Welzijn KB $\quad 60$

Zorg en Welzijn KB verzorging $\quad 54$

Zorg en Welzijn KB zorg en welzijn-breed 49

Zorg en Welzijn BB $\quad 20$

$\begin{array}{ll}\text { Zorg en Welzijn BB verzorging } & 48\end{array}$

Zorg en Welzijn BB uiterlijke verzorging $\quad 26$

Zorg en Welzijn BB zorg en welzijn-breed

BOL niveau $1 / 2$

$A B$ Bol

AB Motorvoertuigen $\quad 23$

AB Beveiliging $\quad 30$

AB Secretarieel

AB Detailhandel/ambulante handel $\quad 14$

AB Groothandel/distributie $\quad 33$

AB Horeca, instellingskeuken en contractcatering $\quad 30$

$A B$ Verpleging en verzorging $\quad 28$

$\begin{array}{ll}\text { BB Plantenteelt } & 31\end{array}$

BB Bloemschikken $\quad 46$

BB Dierverzorging en veterinaire ondersteuning $\quad 53$

BB Groene ruimte $\quad 35$

BB Reclame, presentatie en communicatie

BB Motorvoertuigen $\quad 32$

BB Informatietechniek

$\begin{array}{ll}\text { BB Scheepvaart } & 20\end{array}$

BB Brood- en banketbakken algemeen 38 
Tabel C.6 (vervolg)

Responspercentage per opleidingsrichting

Opleidingsrichting

BOL niveau 1/2 (vervolg)

BB Bedrijfsadministratie

BB Commercieel

BB Secretarieel

BB Detailhandel/ambulante handel

BB Toerisme, recreatie en reizen

BB Facilitaire dienstverlening

41

BB Verpleging en verzorging

BOL niveau $3 / 4$

ZB Plantenteelt

ZB Veehouderij

ZB Bloemschikken

ZB Dierverzorging en veterinaire ondersteuning

ZB Paardenhouderij en paardensport

ZB Groene ruimte

ZB Scheepvaart

ZB Automatisering

ZB Toerisme, recreatie en reizen

$Z B$ Verpleging en verzorging

ZB Uiterlijke verzorging

ZB Maatschappelijke dienstverlening

ZB Sociaal pedagogisch werk

KF Plantenteelt

KF Veehouderij

$\mathrm{KF}$ voedingsmiddelentechnologie

KF Bloemschikken

$\mathrm{KF}$ Dierverzorging en veterinaire ondersteuning

KF Paardenhouderij en paardensport

KF Groene ruimte

KF Milieutoezicht

MKF Bouw

MKF Grond-, water- en wegenbouw

MKF Beschermings- en afwerkingstechnieken

MKF Reclame, presentatie en communicatie

MKF Operationele techniek

MKF Werktuigbouwkunde

MKF Motorvoertuigen

$\begin{array}{ll}\text { MKF Energie- en informatietechniek } & 47\end{array}$

MKF Energietechniek

MKF Informatietechniek

MKF Scheepsbouwkunde

MKF Laboratoriumtechniek

MKF Haven en vervoer

MKF Scheepvaart

MKF Transport en logistiek

MKF Automatisering

MKF Bedrijfsadministratief

MKF Commercieel

MKF Economisch-juridisch

MKF Secretarieel

MKF Detailhandel/ambulante handel

MKF Groothandel/distributie

$\begin{array}{ll}\text { MKF Horeca, instellingskeuken en contractcatering } & 40\end{array}$

$\begin{array}{ll}\text { MKF Toerisme, recreatie en reizen } & 48\end{array}$

$\begin{array}{ll}\text { MKF Assistenten gezondheidszorg } & 49\end{array}$

$\begin{array}{ll}\text { MKF Facilitaire dienstverlening } & 36\end{array}$

$\begin{array}{lr}\text { MKF Sport en bewegen } & 48\end{array}$ 
Tabel C.6 (vervolg)

Responspercentage per opleidingsrichting

Opleidingsrichting

BOL niveau 3/4 (vervolg)

MKF Verpleging en verzorging

MKF Sociaal-cultureel werker

MKF Sociaal-pedagogisch werk algemeen

MKF Sociaal-juridisch werk $\quad 56$

Specialist Automatisering $\quad 22$

BBL niveau $1 / 2$

AB Plantenteelt

$A B$ voedingsmiddelentechnologie $\quad 29$

AB Groene ruimte $\quad 30$

AB Beveiliging $\quad 29$

AB Detailhandel/ambulante handel $\quad 22$

AB Horeca, instellingskeuken en contractcatering $\quad 13$

AB Verpleging en verzorging $\quad 29$

BB Plantenteelt $\quad 33$

BB Veehouderij $\quad 37$

BB voedingsmiddelentechnologie $\quad 30$

BB Bloemschikken $\quad 34$

BB Dierverzorging en veterinaire ondersteuning

BB Paardenhouderij en paardensport $\quad 32$

BB Groene ruimte $\quad 30$

$\begin{array}{ll}\text { BB Bouw } & 27\end{array}$

$\begin{array}{ll}\text { BB Houtbewerking en woninginrichting } & 24\end{array}$

BB Grond-, water en wegenbouw 19

BB Beschermings- en afwerkingstechnieken $\quad 27$

BB Constructie-, plaatwerken/pijpenbewerken $\quad 42$

BB Landbouwmechanisatie $\quad 19$

BB Carrosserie en wagenbouw $\quad 26$

BB Motorvoertuigen $\quad 25$

$\begin{array}{lr}\text { BB Energie- en informatietechniek } & 15\end{array}$

BB Energietechniek 31

BB Installatie-, service- en onderhoudstechniek

$\begin{array}{ll}\text { BB Wegvervoer } & 42\end{array}$

BB Brood- en banketbakken $\quad 28$

BB Secretarieel $\quad 54$

BB Detailhandel/ambulante handel 23

BB Opslag/magazijn 36

BB Horeca, instellingskeuken en contractcatering $\quad 29$

BB Facilitaire dienstverlening $\quad 39$

BB Verpleging en verzorging $\quad 31$

BB Uiterlijke verzorging $\quad 14$

BBL niveau $3 / 4$

ZB Plantenteelt

ZB Bloemschikken

20

ZB Paardenhouderij en paardensport $\quad 36$

ZB Groene ruimte $\quad 41$

ZB Bouw 23

ZB Beschermings- en afwerkingstechnieken $\quad 20$

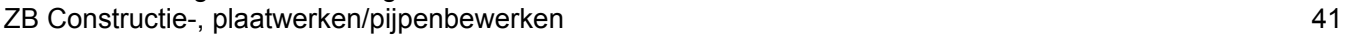


Tabel C.6 (vervolg)

Responspercentage per opleidingsrichting

Opleidingsrichting

BBL niveau 3/4 (vervolg)

ZB Motorvoertuigen

ZB Energietechniek

ZB Installatie-, service- en onderhoudstechniek

19

ZB Fijne techniek

31

ZB Brood- en banketbakken

ZB Detailhandel/ambulante handel

$Z B$ Horeca, instellingskeuken en contractcatering

30

$Z B$ Verpleging en verzorging

ZB Uiterlijke verzorging

ZB Sociaal-pedagogisch werk

37
21

KF Veehouderij

KF voedingsmiddelentechnologie

KF Bloemschikken

KF Groene ruimte

MKF Detailhandel/ambulante handel

MKF Horeca, instellingskeuken en contractcatering $\quad 43$

MKF Assistenten gezondheidszorg $\quad 26$

MKF Verpleging en verzorging $\quad 37$

$\begin{array}{ll}\text { MKF Sociaal-pedagogisch werk } & 43\end{array}$

Specialist Energietechniek $\quad 26$

$\begin{array}{ll}\text { Specialist Verpleging en verzorging } & 44\end{array}$

$\begin{array}{ll}\text { Totaal } & 40\end{array}$ 

D. Opleidingsindeling 



\title{
Overzicht van opleidingen per opleidingssector
}

\author{
HAVO \\ HAVO \\ HAVO Studiehuis \\ VWO \\ VWO Studiehuis \\ Atheneum Studiehuis \\ Gymnasium Studiehuis
}

VMBO Theoretische leerweg

VMBO Theoretische leerweg

VMBO landbouw

VMBO Landbouw

VMBO Landbouw Gem Iw landbouw en nat.omgeving

VMBO Landbouw Gem Iw landbouw-breed

VMBO Landbouw KB landbouw en nat.omgeving

VMBO Landbouw KB landbouw-breed

VMBO Landbouw BB landbouw en nat.omgeving

VMBO Landbouw BB landbouw-breed

VMBO techniek

VMBO Techniek Gem Iw

VMBO Techniek Gem Iw bouw-breed

VMBO Techniek Gem Iw metalektro

VMBO Techniek Gem Iw elektrotechniek

VMBO Techniek Gem Iw transport en logistiek

VMBO Techniek KB

VMBO Techniek KB bouwtechniek

VMBO Techniek KB metaaltechniek

VMBO Techniek KB voertuigentechniek

VMBO Techniek KB electrotechniek

VMBO Techniek KB installatietechniek

VMBO Techniek KB grafische techniek

VMBO Techniek KB transport en logistiek

VMBO Techniek KB overig

VMBO Techniek BB

VMBO Techniek BB bouwtechniek

VMBO Techniek BB bouw-breed

VMBO Techniek BB metaaltechniek

VMBO Techniek BB voertuigentechniek

VMBO Techniek BB electrotechniek

VMBO Techniek BB installatietechniek

VMBO Techniek BB grafische techniek

VMBO Techniek BB transport en logistiek

VMBO Techniek BB overig

VMBO economie

VMBO Economie Gem Iw

VMBO Economie Gem Iw administratie

VMBO Economie Gem Iw handel en administratie 
VMBO Economie KB

VMBO Economie KB administratie

VMBO Economie KB handel en verkoop

VMBO Economie KB handel en administratie

VMBO Economie KB consumptief

VMBO Economie BB

VMBO Economie BB administratie

VMBO Economie BB handel en verkoop

VMBO Economie BB handel en administratie

VMBO Economie BB mode en commercie

VMBO Economie BB consumptief

VMBO gezondheidszorg

VMBO Zorg en Welzijn Gem Iw

VMBO Zorg en Welzijn Gem Iw verzorging

VMBO Zorg en Welzijn Gem Iw zorg en welzijn-breed

VMBO Zorg en Welzijn KB

VMBO Zorg en Welzijn KB verzorging

VMBO Zorg en Welzijn KB uiterlijke verzorging

VMBO Zorg en Welzijn KB zorg en welzijn-breed

VMBO Zorg en Welzijn BB

VMBO Zorg en Welzijn BB verzorging

VMBO Zorg en Welzijn BB uiterlijke verzorging

VMBO Zorg en Welzijn BB zorg en welzijn-breed

$B O L$ niveau $1 / 2$ landbouw

BOL AB Plantenteelt

BOL BB Plantenteelt

BOL BB Veehouderij

$B O L B B$ voedingsmiddelentechnologie

BOL BB Bloemschikken

BOL BB Dierverzorging en veterinaire ondersteuning

BOL BB Paardenhouderij en paardensport

BOL BB Groene ruimte

BOL niveau 1/2 techniek

BOL AB Bouw

BOL AB Constructie-, plaatwerken/pijpenbewerken

BOL AB Montage/Onderhoud/operationele techniek

BOL AB Motorvoertuigen

$B O L A B$ Energie- en informatietechniek

$B O L A B$ Energietechniek

$B O L A B$ Installatie-, service- en onderhoudstechniek

BOL AB Brood- en banketbakken

BOL BB Bouw

BOL BB Houtbewerking en woninginrichting

BOL BB Beschermings- en afwerkingstechnieken

BOL BB Reclame, presentatie en communicatie

BOL BB Constructie-, plaatwerken/pijpenbewerken

BOL BB Machinebankwerken/verspanen

BOL BB Meet- en regeltechniek

BOL BB Operationele techniek

BOL BB Vliegtuigtechnieken

BOL BB Werktuigbouwkunde 
BOL BB Motovoertuigtechniek

BOL BB Motorvoertuigen

BOL BB Energie- en informatietechniek

BOL BB Energietechniek

BOL BB Informatietechniek

BOL BB Installatie-, service- en onderhoudstechniek

BOL BB Fijne techniek

BOL BB Graf. techn, communicatie, audiovisueel en multimedia

BOL BB Mode en kleding (realisatie)

BOL BB Fotonica

BOL BB Procestechniek

BOL BB Scheepvaart

BOL BB Transport en logistiek

BOL BB Wegvervoer

BOL BB Brood- en banketbakken algemeen

$B O L$ niveau 1/2 economie

BOL AB Beveiliging

BOL AB Secretarieel

BOL AB Detailhandel/ambulante handel

BOL AB Groothandel/distributie

$B O L A B$ Horeca, instellingskeuken en contractcatering

BOL BB Economie

BOL BB Bedrijfsadministratie

BOL BB Beveiliging

BOL BB Commerciee

BOL BB Secretarieel

BOL BB Detailhandel/ambulante handel

BOL BB Horeca, instellingskeuken en contractcatering

BOL BB Toerisme, recreatie en reizen

BOL niveau 1/2 gezondheidszorg

$B O L A B$ Verpleging en verzorging

BOL BB Gezondheidszorg

BOL BB Facilitaire dienstverlening

BOL BB Sport en bewegingsleider

BOL BB Verpleging en verzorging

BOL BB Uiterlijke verzorging

BOL niveau 3/4 landbouw

BOL ZB Landbouw

BOL ZB Plantenteelt

BOL ZB Veehouderij

$B O L$ ZB voedingsmiddelentechnologie

BOL ZB Bloemschikken

BOL ZB Dierverzorging en veterinaire ondersteuning

BOL ZB Paardenhouderij en paardensport

BOL ZB Groene ruimte

BOL KF Plantenteelt

BOL KF Veehouderij

BOL KF voedingsmiddelentechnologie

BOL KF Bloemschikken

BOL KF Dierverzorging en veterinaire ondersteuning

BOL KF Paardenhouderij en paardensport 
BOL KF Groene ruimte

BOL KF Milieutoezicht

BOL niveau 3/4 techniek

BOL ZB Techniek

BOL ZB Houtbewerking en woninginrichting

BOL ZB Meet- en regeltechniek

BOL ZB Werktuigbouwkunde

BOL ZB Motorvoertuigen

BOL ZB Energie- en informatietechniek

BOL ZB Informatietechniek

BOL ZB Scheepsbouwkunde

BOL ZB Goudsmid

BOL ZB Graf. techn, communicatie, audiovisueel en multimedia

BOL ZB Mode en kleding

BOL ZB Laboratoriumtechniek

BOL ZB Scheepvaart

BOL ZB Wegvervoer

BOL ZB Brood- en banketbakken

BOL MKF Techniek

BOL MKF Bouw

BOL MKF Houtbewerking en woninginrichting

BOL MKF Grond-, water- en wegenbouw

BOL MKF Beschermings- en afwerkingstechnieken

BOL MKF Reclame, presentatie en communicatie

BOL MKF Instrumenttechniek

BOL MKF Fijnmechanische techniek

BOL MKF Landbouwtechniek

BOL MKF Meet- en regeltechniek

BOL MKF Operationele techniek

BOL MKF Werktuigbouwkunde

BOL MKF Motorvoertuigen

BOL MKF Motorvoertuigen en carrosserietechniek

BOL MKF Energie- en informatietechniek

BOL MKF Energietechniek

BOL MKF Informatietechniek

BOL MKF Scheepsbouwkunde

BOL MKF Edelsmeden

BOL MKF Fijne techniek

BOL MKF Graf. techn, communicatie, audiovisueel en multimedia

BOL MKF Fotonica

BOL MKF Laboratoriumtechniek

BOL MKF Milieutechniek

BOL MKF Procestechniek

BOL MKF Haven en vervoer

BOL MKF Scheepvaart

BOL MKF Transport en logistiek

BOL MKF Brood- en banketbakken

BOL Specialist Techniek

BOL Specialist Energie- en informatietechniek

BOL Specialist Energietechniek

BOL Specialist Informatietechniek 
$B O L$ niveau 3/4 economie

BOL ZB Automatisering

BOL ZB Bedrijfsadministratief

BOL ZB Commercieel

BOL ZB Secretarieel

BOL ZB Detailhandel/ambulante handel

BOL ZB Groothandel/distributie

BOL ZB Toerisme, recreatie en reizen

BOL MKF Economie

BOL MKF Automatisering

BOL MKF Bedrijfsadministratief

BOL MKF Commercieel

BOL MKF Economisch-juridisch

BOL MKF Logistiek

BOL MKF Secretarieel

BOL MKF Administratie - vrije richting

BOL MKF Detailhandel/ambulante handel

BOL MKF Groothandel/distributie

BOL MKF Opslag/magazijn

BOL MKF Textielhandel

BOL MKF Horeca, instellingskeuken en contractcatering

BOL MKF Toerisme, recreatie en reizen

BOL Specialist Economie

BOL Specialist Automatisering

$B O L$ niveau 3/4 gezondheidszorg

BOL ZB Gezondheidszorg

BOL ZB Sport en bewegingsleider

$B O L$ ZB Verpleging en verzorging

BOL ZB Uiterlijke verzorging

BOL MKF Gezondheidszorg

BOL MKF Assistenten gezondheidszorg

BOL MKF Facilitaire dienstverlening

BOL MKF Sport en bewegen

BOL MKF Verpleging en verzorging

BOL MKF Mode en kleding (presentatie)

$B O L$ niveau 3/4 gedrag en maatschappij

BOL ZB Maatschappelijke dienstverlening

BOL ZB Sociaal pedagogisch werk

BOL MKF Maatschappelijke dienstverlening

BOL MKF Sociaal-cultureel werker

BOL MKF Sociaal-pedagogisch werk algemeen

BOL MKF Sociaal-juridisch werk

$B B L$ niveau $1 / 2$ landbouw

BBL AB Plantenteelt

$B B L A B$ voedingsmiddelentechnologie

BBL AB Groene ruimte

BBL BB Plantenteelt

BBL BB Veehouderij

$B B L B B$ voedingsmiddelentechnologie

BBL BB Bloemschikken

BBL BB Dierverzorging en veterinaire ondersteuning 
BBL BB Biologisch-dynamische land- en tuinbouw

BBL BB Paardenhouderij en paardensport

BBL BB Groene ruimte

$B B L$ niveau 1/2 techniek

BBL AB Bouw

$B B L A B$ Beschermings- en afwerkingstechnieken

BBL AB Constructie-, plaatwerken/pijpenbewerken

BBL AB Lassen

BBL AB Montage/Onderhoud/operationele techniek

$B B L A B$ Motorvoertuigen

$B B L A B$ Energie- en informatietechniek

$B B L A B$ Installatie-, service- en onderhoudstechniek

$B B L A B$ Wegvervoer

BBL AB Brood- en banketbakken

BBL BB Techniek

BBL BB Bouw

BBL BB Houtbewerking en woninginrichting

BBL BB Grond-, water en wegenbouw

BBL BB Beschermings- en afwerkingstechnieken

BBL BB Constructie-, plaatwerken/pijpenbewerken

BBL BB Landbouwmechanisatie

BBL BB Lassen

BBL BB Machinebankwerken/verspanen

BBL BB Meet- en regeltechniek

BBL BB Montage/onderhoud/operationele techniek

BBL BB Werktuigbouwkunde

BBL BB Carrosserie en wagenbouw

BBL BB Motorvoertuigen

BBL BB Energie- en informatietechniek

BBL BB Energietechniek

BBL BB Installatie-, service- en onderhoudstechniek

BBL BB Graf. techn, communicatie, audiovisueel en multimedia

BBL BB Laboratoriumtechniek

BBL BB Procestechniek

BBL BB Wegvervoer

BBL BB Brood- en banketbakken

$B B L$ niveau $1 / 2$ economie

BBL AB Beveiliging

BBL AB Secretarieel

$B B L A B$ Detailhandel/ambulante handel

$B B L A B$ Horeca, instellingskeuken en contractcatering

BBL BB Bedrijfsadministratief

BBL BB Beveiliging

BBL BB Secretarieel

BBL BB Detailhandel/ambulante handel

BBL BB Opslag/magazijn

BBL BB Horeca, instellingskeuken en contractcatering

BBL BB Toerisme, recreatie en reizen

$B B L$ niveau 1/2 gezondheidszorg

$B B L A B$ Verpleging en verzorging

BBL BB Facilitaire dienstverlening 
BBL BB Verpleging en verzorging

BBL BB Uiterlijke verzorging

$B B L$ niveau 3/4 landbouw

BBL ZB Landbouw

BBL ZB Plantenteelt

$B B L$ ZB Veehouderij

$B B L Z B$ voedingsmiddelentechnologie

BBL ZB Bloemschikken

$B B L$ ZB Dierverzorging en veterinaire ondersteuning

BBL ZB Paardenhouderij en paardensport

BBL ZB Groene ruimte

BBL KF Plantenteelt

BBL KF Veehouderij

BBL KF voedingsmiddelentechnologie

BBL KF Bloemschikken

$B B L K F$ Dierverzorging en veterinaire ondersteuning

BBL KF Paardenhouderij en paardensport

BBL KF Groene ruimte

BBL Specialist Bloemschikken

BBL niveau 3/4 techniek

BBL ZB Bouw

$B B L$ ZB Houtbewerking en woninginrichting

BBL ZB Grond-, water- en wegenbouw

BBL ZB Beschermings- en afwerkingstechnieken

BBL ZB Constructie-, plaatwerken/pijpenbewerken

BBL ZB Landbouwmechanisatie

$B B L$ ZB Meet- en regeltechniek

BBL ZB Montage/onderhoud/operationele techniek

BBL ZB Wertuigbouwkunde

BBL ZB Carrosserie en wagenbouw

BBL ZB Motorvoertuigen

BBL ZB Energie- en informatietechniek

BBL ZB Energietechniek

BBL ZB Informatietechniek

BBL ZB Beheer, ontwerp en management (instal. techn)

BBL ZB Installatie-, service- en onderhoudstechniek

BBL ZB Fijne techniek

BBL ZB Graf. techn, communicatie, audiovisueel en multimedia

BBL ZB Procestechniek

BBL ZB Scheepvaart

BBL ZB Wegvervoer

BBL ZB Brood- en banketbakken

BBL MKF Techniek

BBL MKF Bouw

BBL MKF Houtbewerking en woninginrichting

BBL MKF Motorvoertuigen

BBL MKF Graf. techn, communicatie, audiovisueel en multimedia

BBL MKF Mode en kleding (realisatie)

BBL MKF Transport en logistiek

BBL Specialist Werktuigbouwkunde

BBL Specialist Motorvoertuigen

BBL Specialist Energie- en informatietechniek 
BBL Specialist Energietechniek

BBL Specialist Informatietechniek

BBL niveau 3/4 economie

$\mathrm{BBL}$ ZB Automatisering

BBL ZB Bedrijfsadministratief

BBL ZB Logistiek

BBL ZB Secretarieel

BBL ZB Detailhandel/ambulante handel

BBL ZB Groothandel/distributie

BBL ZB Opslag/magazijn

BBL ZB Horeca, instellingskeuken en contractcatering

BBL ZB Toerisme, recreatie en reizen

BBL MKF Automatisering

BBL MKF Bedrijfsadministratief

BBL MKF Commercieel

BBL MKF Economisch-juridisch

BBL MKF Logistiek

BBL MKF Secretarieel

BBL MKF Detailhandel/ambulante handel

BBL MKF Groothandel/distributie

BBL MKF Opslag/magazijn

BBL MKF Horeca, instellingskeuken en contractcatering

BBL Specialist Automatisering

BBL niveau 3/4 gezondheidszorg

$B B L$ ZB Verpleging en verzorging

BBL ZB Uiterlijke verzorging

BBL MKF Assistenten gezondheidszorg

BBL MKF Verpleging en verzorging

BBL Specialist Verpleging en verzorging

BBL niveau 3/4 gedrag en maatschappij

BBL ZB Gedrag en maatschappij

BBL ZB Sociaal-pedagogisch werk

BBL MKF Sociaal-cultureel werk

BBL MKF Sociaal-pedagogisch werk

BBL MKF Sociaal-juridisch werk

HBO landbouw

HBO Landbouw/produktie

HBO Landbouw/bedrijfskunde

HBO Milieu/groene ruimte

HBO Technologie/laboratorium

HBO Agrarische docentopl.

HBO Plattelandsvernieuwing

HBO B Voedingsmiddelentechnologie

HBO B Bedrijfskunde en Agribusiness

HBO B Tuinbouw en Akkerbouw

HBO B Dier- en veehouderij

HBO B Land- en watermanagement

HBO B Laboratoriumtechniek 


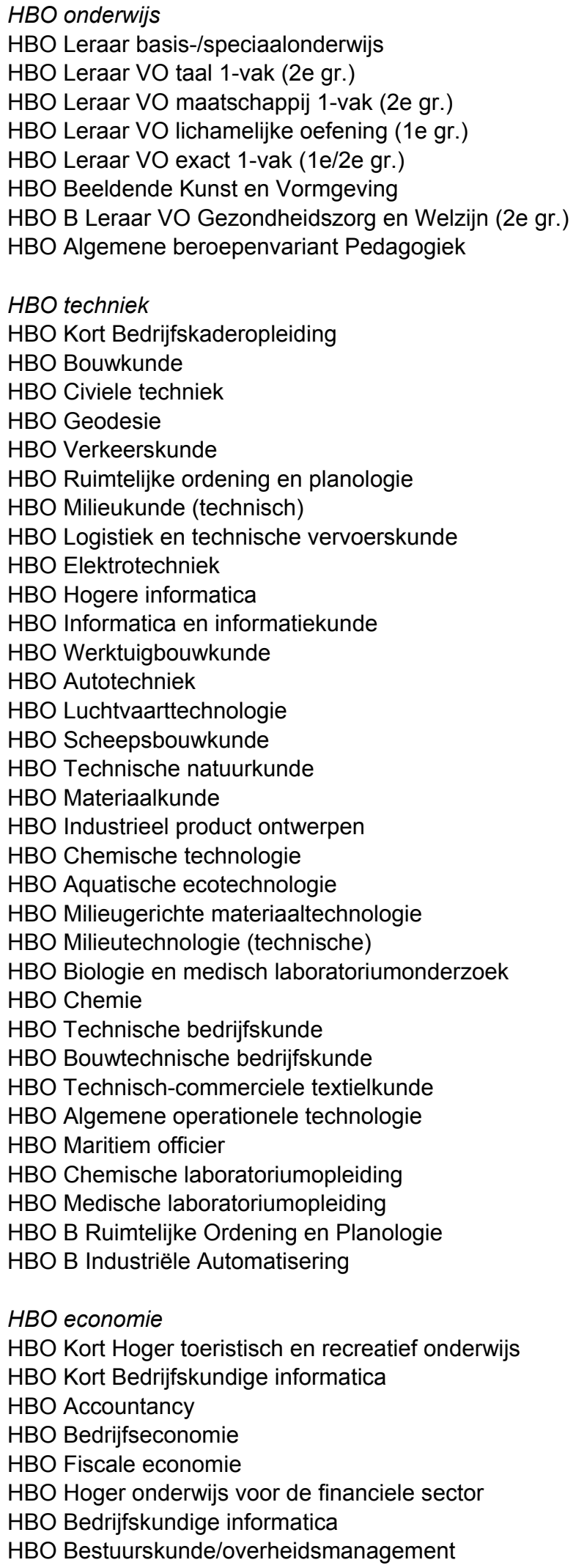


HBO Management, economie en recht

HBO Bedrijfswiskunde

HBO Commerciele economie

HBO Logistiek en economie

HBO Small business en retail management

HBO Communicatie

HBO Communicatiesystemen

HBO Hogere Europese beroepenopleiding

HBO Journalistiek en voorlichting

HBO Opleiding tolk-vertaler

$\mathrm{HBO}$ Orientaalse talen en communicatie

HBO Informatiedienstverlening en -management

HBO Facilitaire dienstverlening

HBO Hoger hotelonderwijs

HBO Hoger toeristisch en recreatief onderwijs

HBO Vrijetijdskunde

HBO B International Business and Languages

HBO B Food \& Business

HBO B Facility Management

HBO B Vrijetijdsmanagement

HBO B Marketing management (4-jarig)

HBO B Sport, Management en Ondernemen

HBO B Ondernemerschap

HBO B International Business and Management Studies

HBO B Kunst en Economie

HBO gezondheidszorg

HBO Opleiding tot verpleegkundige

HBO Opl. verpleegkundige maatschappelijke gezondheidszorg

HBO Opleiding van kader in de gezondheidszorg

HBO Bewegingstechnologie

HBO Medisch beeldvormende/radiotherapeutische technieken

HBO Fysiotherapie

HBO Ergotherapie

HBO Logopedie

HBO Optometrie

HBO Voeding en dietetiek

HBO Antroposofische gezondheidszorg

HBO Opleiding mondhygienist

HBO Opleiding tot orthoptist

HBO Bewegingsagogie/psychomotorische therapie

HBO Huidtherapie

HBO Opleiding podotherapie

HBO Sport en bewegen

HBO Oefentherapie Cesar/Mensendieck

HBO B Sport, Gezondheid en Management

HBO gedrag en maatschappij

HBO Creatieve therapie

HBO Culturele en maatschappelijke vorming

HBO Maatschappelijk werk en dienstverlening

HBO Personeel en arbeid

HBO Sociaal-juridische dienstverlening

HBO Sociaal pedagogische hulpverlening

HBO Hoger pedagogisch en sociaal-agogisch onderwijs 
HBO Godsdienst-pastoraal werk

HBO Integrale Veiligheidszorg (IVZ)

HBO taal en cultuur

HBO Beeldende Kunst en Vormgeving

HBO Film en Televisie

HBO Muziek

HBO Theater

HBO Dans

HBO Museologie

$\mathrm{HBO}$ Overige kunstopleidingen

WO landbouw

WO Bos- en natuurbeheer

WO Landinrichtingswetenschappen

WO Tropisch landgebruik

WO Plantenteeltwetenschappen

WO Plantenveredeling en gewasbescherming

WO Zootechniek

WO Voeding en gezondheid

WO Bioprocestechnologie

WO Levensmiddelentechnologie

WO Landbouwtechniek

WO Economie van landbouw en milieu

WO Rurale ontwikkelingsstudies

WO Huishoud- en consumentenwetenschappen

WO Agrosysteemkunde

WO Bodem, water en atmosfeer

WO Biologie

WO Milieuhygiene

WO Moleculaire wetenschappen

WO onderwijs

WO Kort Onderwijs

WO Kort univ. leraaropl. Engels

WO Kort Univ. leraaropl. Frans

WO Kort Univ. leraaropl. Grieks en Latijn (Klassieken)

WO Kort Univ. leraaropl. Nederlands

WO Kort Univ. leraaropl. Spaans

WO Kort Univ. leraaropl. geschiedenis en staatsinrichting

WO Kort Univ. leraaropl. biologie

WO Kort Univ. leraaropl. natuurkunde

WO Kort Univ. leraaropl. scheikunde

WO M Leraar VO Nederlands (1e gr.)

WO M Leraar VO Scheikunde (1e gr.)

WO M Leraar VO Biologie (1e gr.)

WO M Leraar VO Aardrijkskunde (1e gr.)

WO techniek

WO Technische aardwetenschappen

WO Scheikundige technologie en bioprocestechnologie

WO Technische natuurkunde

WO Technische wiskunde

WO Biomedische technologie 
WO Bedrijfsinformatietechnologie

WO Technische informatica

WO Elektrotechniek

WO Bouwkunde

WO Civiele techniek

WO Geodesie

WO Installatietechniek

WO Industrieel ontwerpen

WO Luchtvaart- en ruimtevaarttechniek

WO Maritieme techniek

WO Materiaalkunde

WO Werktuigbouwkunde

WO Technische bedrijfskunde

WO Technische bestuurskunde

WO Techniek en maatschappij

WO Wijsbegeerte, wetenschap, technologie en samenleving

WO Informatica

WO economie

WO Economie

WO Fiscale economie

WO Japankunde

WO Actuariele wetenschappen

WO Econometrie

WO Operationele research en management

WO Econometrie en operationele research

WO Bedrijfskunde

WO Bedrijfswetenschappen

WO Technische bedrijfswetenschappen

WO Domeingerichte economie

WO M Econometrics

WO M Accountancy \& Control

WO M Business Economics

WO M Economics

WO M Fiscale Economie

WO gezondheidszorg

WO Diergeneeskunde

WO Geneeskunde

WO Tandheelkunde

WO Bewegingswetenschappen

WO Biomedische wetenschappen

WO Gezondheidswetenschappen

WO Beleid en beheer van de gezondheidszorg (BB)

WO Bewegingswetenschappen (BW)

WO Biologische gezondheidkunde (BGK)

WO Geestelijke gezondheidkunde (GGK)

WO Gezondheidsvoorlichting (GVO)

WO Verplegingswetenschap (VW)

WO Gezondheidswetenschappen Arbeid en Gezondheidszorg

WO Medische biologie

WO Medische informatiekunde

WO Milieugezondheidkunde 
WO Algemene Gezondheidswetenschappen

WO B Biomedische wetenschappen

WO gedrag en maatschappij

WO Psychologie

WO Sociaal-wetenschappelijke informatica

WO Technische cognitiewetenschap

WO Pedagogische wetenschappen

WO Onderwijskunde

WO Toegepaste onderwijskunde

WO Communicatiewetenschap

WO Toegepaste communicatiewetenschap

WO Algemene sociale wetenschappen

WO Culturele antropologie/Soc niet-Westerse samenlevingen

WO Sociaal-culturele wetenschappen

WO Sociologie

WO Vrijetijdswetenschappen

WO Sociale geografie en Planologie

WO Milieu-maatschappijwetenschapen

WO Arbeid en sociale zekerheid

WO Personeelwetenschappen

WO Recht, bestuur en management

WO Beleids- en organisatiewetenschappen

WO Beleidsgerichte milieukunde

WO Bestuurskunde

WO Politicologie

WO Planologie

WO Sociale geografie

WO Technische planologie

WO Demografie

WO Juridische bestuurswetenschappelijke opleiding

WO Kunstmatige intelligentie

WO taal en cultuur

WO Griekse en Latijnse talen en culturen

WO Latijnse taal- en letterkunde

WO Nederlandse taal- en letterkunde

WO Duitse taal- en letterkunde

WO Engelse taal- en letterkunde

WO Franse taal- en letterkunde

WO Italiaanse taal- en letterkunde

WO Keltische talen en cultuur

WO Portugese taal- en letterkunde

WO Roemeense taal- en letterkunde

WO Romaanse talen en culturen

WO Scandinavische talen en hun letterkunde

WO Spaanse taal- en letterkunde

WO Talen en culturen van Latijns Amerika

WO Arabische, Nieuwperzische en Turkse talen en culturen

WO Chinese talen en culturen

WO Talen en culturen van Zuidoost-Azie en Oceanie

WO Japanse taal en cultuur

WO Nieuwgriekse taal- en letterkunde

WO Semitische talen en culturen 
WO Slavische talen en hun letterkunde

WO Taalwetenschap

WO Alfa-informatica

WO Algemene literatuurwetenschap

WO Algemene taalwetenschap

WO Afrikanistiek

WO Amerikanistiek

WO Dutch studies

WO Europese studies

WO Oost-europese studies

WO Ruslandkunde

WO Bedrijfscommunicatie letteren

WO Boek- en informatiewetenschap

WO Communicatiekunde

WO Beleid en bestuur internationale organisaties

WO Culturele studies

WO Cultuur- en wetenschapsstudies

WO Film- en televisiewetenschappen

WO Muziekwetenschap

WO Taal- en cultuurstudies

WO Theater-, film- en televisiewetenschappen

WO Cultuurwetenschappen

WO Algemene opleiding godgeleerdheid

WO Godgeleerdheid

WO Godsdienstwetenschappen

WO Religie en levensbeschouwing

WO Religiestudies

WO Sociaal-wetenschappelijke studie van de godsdienst

WO Archeologie

WO Europese archeologie

WO Comm. en informatiewetenschappen

WO Geschiedenis

WO Kunstgeschiedenis en archeologie

WO Medievistiek

WO Oudheidkunde

WO Wijsbegeerte

WO Wijsbegeerte op basis niet wijsgerige propedeuse

WO Wijsbegeerte van een bepaald wetenschapsgebied

WO B Archeologie

WO B Communicatie- en informatiewetenschappen

WO M Christendom en Islam

WO recht en openbare orde

WO Nederlands recht

WO Nederlands recht, internationale/Europees rechtelijke opl

WO Notariele opleiding

WO Fiscaal-juridische opleiding

WO European Law school

WO Internationaal recht

WO Internationaal-juridische opleiding

WO Juridische bestuurswetenschappelijke opleiding

WO Juridisch-politiekwetenschappelijke opleiding

WO Internationaal en Europees recht

WO Fiscaal recht 
WO Notarieel recht

WO Internationaal en Europees recht

WO M Notarieel Recht

WO natuurwetenschappen

WO Medische biologie

WO Bedrijfs- en industriele statistiek

WO Statistiek

WO Wiskunde

WO Bedrijfsinformatiesystemen

WO Bedrijfswiskunde en informatica

WO Kennistechnologie

WO Kunstmatige intelligentie

WO Kunstmatige intelligentie

WO Infortmatiekunde

WO Natuurkunde

WO Sterrrenkunde

WO Natuur- en sterrenkunde

WO Aardwetenschappen

WO Algemene Natuurwetenschappen

WO Geologie

WO Fysische geografie

WO Scheikunde

WO Biofarmaceutische wetenschappen

WO Farmacie

WO Farmacochemie

WO Biologie

WO Natuurwetenschappelijke milieukunde

WO Milieuwetenschappen/aardwetenschappen

WO Milieuwetenschappen/biologie

WO Wetenschapsdynamica

WO Milieu-natuurwetenschappen

WO B Life Science \& Technology

WO B Scheikunde

WO B Biologie

WO B Informatica

WO M Mediatechnology

WO M Chemistry 